KÁTIA AUDI TATEMOTO

ENERGIA INCENTIVADA: UMA ANÁLISE INTEGRADA DOS ASPECTOS REGULATÓRIOS, DE COMERCIALIZAÇÃO E DE SUSTENTABILIDADE

São Paulo

2013 
KÁTIA AUDI TATEMOTO

\section{ENERGIA INCENTIVADA: UMA ANÁLISE INTEGRADA DOS ASPECTOS REGULATÓRIOS, DE COMERCIALIZAÇÃO E DE SUSTENTABILIDADE}

Dissertação apresentada à Escola Politécnica da Universidade de São Paulo para obtenção do título de Mestre em Ciências

Área de Concentração: Energia

Orientador: Prof. Dr. Dorel Soares Ramos

São Paulo 
Este exemplar foi revisado e corrigido em relação à versão original, sob responsabilidade única do autor e com anuência de seu orientador.

São Paulo, 29 de abril de 2013.

Assinatura do autor

Assinatura do orientador

FICHA CATALOGRÁFICA

Tatemoto, Audi Kátia

Energia Incentivada: Uma análise integrada dos aspectos regulatórios, de comercialização e de sustentabilidade / K.A Tatemoto. - versão corr. - São Paulo, 2013. $162 \mathrm{p}$

Dissertação (Mestrado) -, Escola Politécnica da Universidade de São Paulo. Departamento de Engenharia de Energia e Automação Elétricas.

1. Energia 2.Sustentabilidade I. Universidade de São Paulo. Escola Politécnica. Departamento de Engenharia de Energia e Automação Elétricas II. t. 


\section{DEDICATÓRIA}

A minha mãe Célia (em memória)

Ao meu marido Érico e meu filho Matheus

Ao meu orientador Prof. Dr. Dorel Soares Ramos 


\section{AGRADECIMENTOS}

Ao Prof. Dr. Dorel Soares Ramos pela orientação, atenção, disponibilidade e pontualidade durante a execução deste trabalho.

Aos membros da banca do Exame de Qualificação Profa. Dra.Eliane Fadigas e Prof.

Dr. Fernando Amaral de Almeida Prado Jr, pelas contribuições que enriqueceram muito o trabalho.

Ao meu marido Érico pelo incentivo durante a execução deste trabalho.

Ao meu filho Matheus.

A minha querida mãe Célia (em memória). 


\section{RESUMO}

O objetivo deste trabalho é apresentar uma análise dos aspectos regulatórios e de comercialização sob a visão da sustentabilidade, com foco na questão de como a participação crescente das fontes consideradas incentivadas na matriz elétrica brasileira pode proporcionar benefícios energéticos e de redução nas emissões de gases de efeito estufa, contemplando possíveis aperfeiçoamentos regulatórios que possam vir a ser definidos pelas instituições do setor elétrico que detém essa competência.

Destaca-se a seqüência de fatos que contribuíram para a ampliação da oferta das fontes alternativas (FA's), sublinhando: (i) a criação do Programa de Incentivo às FA's (PROINFA); (ii) o regramento para a comercialização de Energia Incentivada; (iii) o Mecanismo de Realocação de Energia (MRE); (iv) facilidades para compra de Geração Distribuída pelas distribuidoras, mitigar o risco de variação de mercado; (v) Leilões de Fontes Alternativas e (vii) Leilões de Energia de Reserva (LER).

Nesse âmbito de análise, inclui-se uma aferição de risco de comercialização da Energia Incentivada e de como esse risco pode ser mitigado através de "hedge" contratual entre fontes incentivadas. Para avaliar e qualificar a sinergia entre energia eólica e da biomassa, que tem perfil de produção complementar às Pequenas Centrais Hidrelétricas ( $\mathrm{PCH}$ 's), foram realizadas simulações de análise de complementariedade de geração para identificar a melhor estratégia de contratação de energia, a fim de buscar a máxima receita líquida possível, atendendo restrições de risco.

Finalmente, são apresentadas propostas de alterações regulatórias e comerciais que estão sendo discutidas no setor e que ainda não estão aprovadas, porém são consideradas relevantes e impactantes no que diz respeito à energia incentivada, destacando-se a possibilidade de cessão de energia excedente pelos consumidores livres e especiais; a criação de penalidades por alavancagem; a proposta de criação do Comercializador varejista; e dos certificados de energia (CEE's). 


\section{ABSTRACT}

This work is aiming at to present an analysis of the regulatory aspects and commercialization, under sustainability point of view, focusing with special emphazis the question on how the increasing of incentivized sources participation in the Brazilian energy matrix can provide energy benefits and reduction of greenhouse emissions, considering possible regulatory improvements that may be defined by the adequate institutions of the Brazilian electrical sector (BES).

Highlighting the sequence of events that contributed to increase the expansion of alternative sources (FA's), it should be worthwhile to stress: (i) the creation of the Incentive Program for FA's (PROINFA); (ii) the rules for the commercialization of the Energy with Incentive; (iii) the Energy Reallocation Mechanism (MRE); (iv) facilities for the purchase of Distributed Generation by distributors having the purpose of mitigating the market risk represented by the exposure to the short term market price (Market Cleasing Price); (v) Energy Auctions of Alternative sources (vii) Energy Auctions Reserve (LER).

The context of the analysis carried out includes the assessment of commercialization risk affecting FA's and how this risk can be mitigated through of "hedge" contracts between different FA's. To evaluating and qualify the synergy between Wind and biomass plants, which has production with complementary profile to the Small Hydro Power (PCH's), simulations were performed to identify the best strategy to energy contracting, considering the objective of maximum profit under riskconstraints.

Finally, some proposals of commercial and regulatory changes are presented, being important to emphasize that the quoted proposals are now in a discussion process in the BES, meaning that they are not approved yet. However, it is relevant to consider these news possibilities, as they impact the economic feasibility of incentivized energy, highlighting the possibility of to sell eventual surplus in the short term marketby free consumer; the creation of penalties for leverage; the creation of an agent focused on small free consumers (special consumers) commercialization, and energy certificates (CEE's). 


\section{LISTA DE FIGURAS}

Figura 1: Visão Geral das Relações Contratuais............................................. 12

Figura 2: Esquema dos Ambientes de Contratação........................................ 13

Figura 3: Planejamento da Operação....................................................... 15

Figura 4: Opções de contratação das distribuidoras. ........................................ 21

Figura 5: Processo de alocação de energia assegurada e energia secundária quando a geração total é superior à energia assegurada total do MRE.

Figura 6: Alocação e redução de energia assegurada quando a geração total é inferior à energia assegurada total do MRE.

Figura 7: Representação da verificação de atendimento ao limite de $49 \%$ da Garantia Física, para o registro de contratos de compra de energia de fontes não especiais.

Figura 8: Representação da Modelagem do Gerador ou Comercialização para comercialização de energia convencional e energia incentivada.

Figura 9: Representação da Modelagem Consumidor Livre para comercialização de energia convencional e do Consumidor Especial energia para comercialização de energia incentivada.

Figura 10: Representação da Modelagem em relações comerciais de forma simplificada envolvendo a energia incentivada.

Figura 11: Representação do processo de sazonalização de um contrato bilateral no Ambiente de Contratação Livre (ACL).

Figura 12: Representação do processo de modulação de um contrato bilateral, respeitados os limites mensais contratados.

Figura 13: Descontos para a montagem simplificada da montagem da Matriz A. .... 64

Figura 14: Cenário 01 - Repasse da perda dos descontos 66

Figura 15: Cenário 02: Repasse da perda dos descontos.

Figura 16: Cenário 03: Demonstração da questão do repasse da perda dos descontos

Figura 17: Exemplo de perfil de um consumidor livre ou especial para apuração de penalidade por Insuficiência de Cobertura Contratual de Consumo.

Figura 18: Exemplo de perfil de um gerador para apuração de penalidade por Insuficiência de Cobertura Contratual de Consumo. 
Figura 19: Obtenção do valor de penalidade por insuficiência de lastro/cobertura

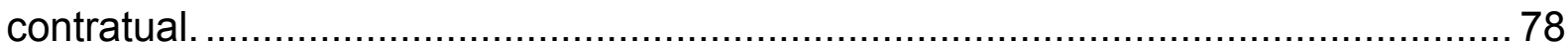

Figura 20: Comparação entre garantia física e carga do SIN. ................................78

Figura 21: Valor do Fator de Sobras de Lastro de Energia (anos 2005 a 2010)...... 79

Figura 22: Parâmetros do valor da penalidade por insuficiência de lastro/cobertura contratual.

Figura 23: Exemplo de Exposição Positiva e Negativa de um contrato à diferença de preços de liquidação das diferenças entre submercados....................................... 82

Figura 24: Visão Geral do Processo do CEE (Sugestão)...................................... 84

Figura 25: Representação da energia comercializada pela Eletrobrás na CCEE. .... 88 Figura 26: Contratos e Fluxo financeiro decorrentes da contratação de Energia de

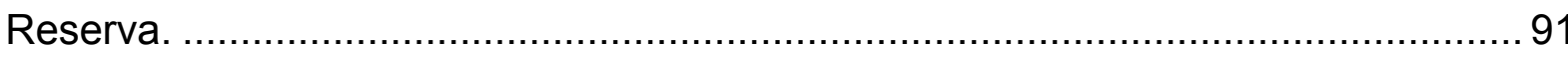

Figura 27: Fluxo de recursos financeiros da CONER ........................................... 93

Figura 28: Oferta Interna de Energia Elétrica (OIEE) ......................................... 100

Figura 29: Oferta Interna de Energia Elétrica (OIEE) ...................................... 100

Figura 30: Atlas do Potencial Eólico Brasileiro.................................................... 112

Figura 31: Instituições do Setor Elétrico Brasileiro............................................ 142 


\section{LISTA DE GRÁFICOS}

Gráfico 1: Gráfico do Número de Consumidores Livres x Número de Consumidores Especiais 43

Gráfico 2: Representação reginal da capacidade instalada no SIN 102

Gráfico 3: Acréscimo de capacidade instalada de outras fontes renováveis (MW). 104 Gráfico 4: Participação das fontes de produção em 2015 e em 2021 (MW). 104 Gráfico 5: Evolução da participação das fontes de produção na capacidade instalada do SIN (\%). 105

Gráfico 6: Evolução da capacidade instalada por fonte de geração (GW e \%)....... 105 Gráfico 7: Acréscimo de capacidade instalada anual por fonte (MW). 106 Gráfico 8: Oferta Interna de Energia Elétrica por Fonte de Eletricidade no Brasil em 2011.

Gráfico 9: Estimativas de Níveis das emissões de CO2.

Gráfico 10: Gráfico de Geração de Energia Eólica - SIN. 113

Gráfico 11: Gráfico de Geração de Energia Eólica - Norte e Nordeste. 114 Gráfico 12: Gráfico de Geração de Energia Eólica - S_SE_CO. 114 Gráfico 13: Análise de uma PCH (a) operando comercialmente de forma isolada, com preço de venda a $\mathrm{R} \$ 150,00 / \mathrm{MWh}$.

Gráfico 14: Análise de uma usina eólica (b) operando comercialmente de forma isolada, com preço de venda a $R \$ 150,00 / \mathrm{MWh}$.

Gráfico 15: Análise de complementação eólica (b) e PCH (a), operando comercialmente em conjunto, com preço de venda a $\mathrm{R} \$ 150,00$

Gráfico 16: Análise de complementação térmica a biomassa (c) e PCH (a), operando comercialmente em conjunto, com preço de venda a $\mathrm{R} \$ 150,00$

Gráfico 17: Análise de uma usina eólica (b) operando comercialmente de forma isolada, com preço de venda a $\mathrm{R} \$ 130,00 / \mathrm{MWh}$.

Gráfico 18: Análise de uma usina eólica (b) operando comercialmente de forma isolada, com preço de venda a $\mathrm{R} \$ 130,00 / \mathrm{MWh}$.

Gráfico 19: Análise de complementação eólica (b) e PCH (a), operando em conjunto, com preço de venda a $\mathrm{R} \$ 130,00$.

Gráfico 20: Análise de complementação termelétrica a biomassa (c) e PCH (a), operando em conjunto, com preço de venda a $R \$ 130,00 / \mathrm{MWh}$. 


\section{LISTA DE TABELAS}

Tabela 1: Exemplo de Cálculo de fator de desconto na Tarifa de Transporte para Energia Incentivada Comercializada por Agentes Geradores - Caso (1) Garantia Física (GF) + Contratos de Compra (CCEI Compra) = Contratos de Venda (CCEI Venda) e Caso (2) Garantia Física (GF) + Contratos de Compra (CCEI Compra) > Contratos de Venda (CCEI Venda), respectivamente.

Tabela 2: Exemplo de Cálculo de fator de desconto na Tarifa de Transporte para Energia Incentivada Comercializada por Agentes Geradores - Caso (3) Garantia Física (GF) + Contratos de Compra (CCEI Compra) < Contratos de Venda (CCEIVenda) e Caso (4)

Garantia

Física (GF) + Contratos de Compra (CCEI Compra) < Contratos de Venda (CCEI Venda [Desconto da usina $=0 \%$, respectivamente.

Tabela 3: Exemplo de Cálculo de fator de desconto na Tarifa de Transporte para Energia Incentivada Comercializada por Agentes Comercializadores - Caso (1) Contratos de Compra (CCEI Compra) = Contratos de Venda (CCEI Venda), Caso (2) Contratos de Compra (CCEI Compra) > Contratos de Venda (CCEI Venda) e Caso (3) Contratos de Compra (CCEI Compra) < Contratos de Venda (CCEI Venda), respectivamente.

Tabela 4: Exemplo de Cálculo de fator de desconto na Tarifa de Transporte para Energia Incentivada Comercializada por Agentes Consumidores Livres e Consumidores Especiais - Caso (1) Consumidores Especiais: Contratos de Compra (CCEICompra) $=$ Contratos de Venda (CCEIVenda), Caso (2) Consumidores Livres e Especiais: Contratos de Compra (CCEICompra) + Contratos de Compra (CCCompra Energia Convencional ) e Caso (3) Consumidores Livres e Especiais: Contratos de Compra (CCEICompra) + Insuficiência de Cobertura contratual de Consumo, respectivamente.

Tabela 5: Dados numéricos do consumidor livre ou especial para demonstração do cálculo de apuração de penalidade por Insuficiência de Cobertura Contratual de Consumo.

Tabela 6: Dados numéricos do consumidor livre ou especial para demonstração do cálculo do valor da penalidade por Insuficiência de Cobertura Contratual de Consumo. 
Tabela 7: Dados numéricos do gerador para demonstração do cálculo de apuração de penalidade por Insuficiência de Cobertura Contratual de Consumo.

Tabela 8: Dados numéricos do gerador para demonstração do cálculo do valor da penalidade por Insuficiência de Cobertura Contratual de Consumo. .75

Tabela 9: Oferta Interna de Energia Elétrica (OIEE) (GWh e \%). ........................... 98

Tabela 10: Oferta Interna de Energia Elétrica (OIEE) (GWh e \%). .......................... 99

Tabela 11: Expansão de biomassa, PCH e eólica de 2012 a 2016 ...................... 103

Tabela 12: Estimativa de investimentos em geração de energia. .......................... 107

Tabela 13: Tabela de Geração de Energia Eólica no SIN (MW médios). ............... 143

Tabela 14: Gráfico de Geração de Energia Eólica - Norte e Nordeste (MW médios). 144

Tabela 15: Gráfico de Geração de Energia Eólica - S_SE_CO (MW médios). ...... 144 


\section{LISTA DE ABREVIATURAS E SIGLAS}

ACL

ACR

ANEEL

BEN

CCD

CCEE

CCEI

CCEAR

CCT

CEE

CER

$\mathrm{CMO}$

CONUER

CONER

CNPE

CQNUMC

Clima

CUSD

CUST

EER

EPE

GEE

IPCC

LER

MDL

MCP

MME
Ambiente de Contratação Livre

Ambiente de Contratação Regulada

Agência Nacional de Energia Elétrica

Balanço Energético Nacional

Contrato de Conexão ao Sistema de Distribuição

Câmara de Comercialização de Energia Elétrica

Contrato de Comercialização de Energia Incentivada

Contrato de Compra de Energia no Ambiente Regulado

Contrato de Conexão aos Sitemas de Transmissão

Certificado de Energia Elétrica

Conta de Energia de Reserva

Custo Marginal de Operação do Sistema

Contrato de Uso da Energia de Reserva

Conta de Energia de Reserva

Conselho Nacional de Política Energética

Convenção-Quadro das Nações Unidas sobre a Mudança do

Contrato de Uso do Sistema de Distribuição

Contrato de Uso do Sistema de Transmissão

Encargo de Energia de Reserva

Empresa de Pesquisa Energética

Gás de Efeito Estufa

Intergovernamental Panel on Climate change

Leilão de Energia de Reserva

Mecanismo de Desenvolvimento Limpo

Mercado de curto Prazo

Ministério de Minas e Energia 
MRE

OIE

ONS

$\mathrm{PCH}$

$\mathrm{PdC}$

PDE

PIE

PLD

PNE

PNMC

PROINFA

SCL

SIN

SMF

TUSD

TUST

UNFCCC
Mecanismo de Realocação de Energia

Oferta Interna de Energia

Operador Nacional do Sistema Elétrico

Pequena Central Hidrelétrica

Procedimento de Comercialização

Plano Decenal de Energia

Produtor Independente de Energia Elétrica

Preço de Liquidação das Diferenças

Plano Nacional de Energia

Plano Nacional de Mudança do Clima

Programa de Incentivo às Fontes Alternativas

Sistema de Contabilização e Liquidação da CCEE

Sistema Interligado Nacional

Sistema de Medição e Faturamento

Tarifa de Uso do Sistema de Distribuição

Tarifa de Uso do Sistema de Transmissão

United Nations Framework Convention on Climate Change 


\section{SUMÁRIO}

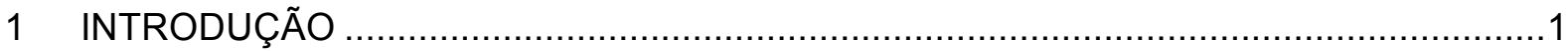

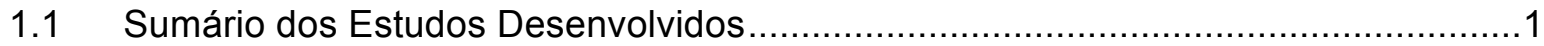

1.2 Integração dos Assuntos Regulatórios, de Comercialização e Sustentabilidade ......5

2 COMERCIALIZAÇÃO DE ENERGIA ELÉTRICA .......................................................

2.1 Modelo Insitucional do Setor Elétrico: Retrospectiva Regulatória ..........................7

2.2 Relações Contratuais e Comerciais no Modelo Institucional vigente no Setor Elétrico

2.2.1 A natureza do contrato de compra e venda de energia elétrica ........................8

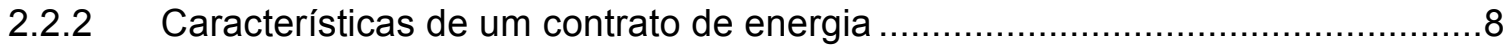

2.2.3 Ambientes de Contratação - Definições Básicas ............................................

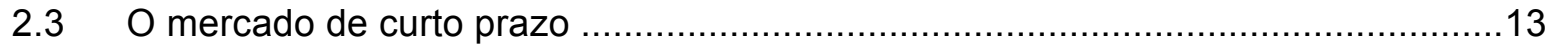

2.4 A regulamentação das relações contratuais e comerciais ......................................16

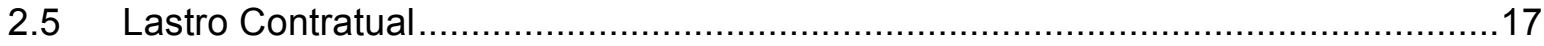

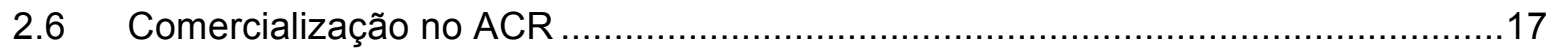

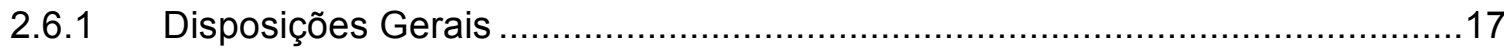

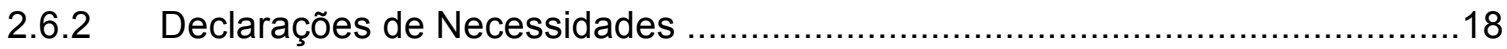

2.6.3 Leilões para Compra de Energia Elétrica .................................................19

2.6.4 Contratos de Compra e Venda de Energia no Ambiente Regulado .................23

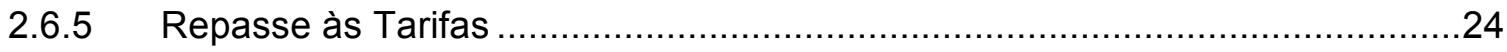

3 REGRAS E PROCEDIMENTOS DE COMERCIALIZAÇÃO ....................................28

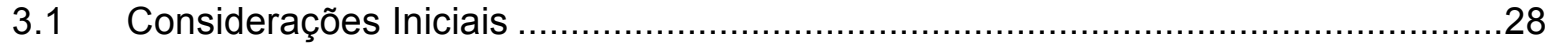

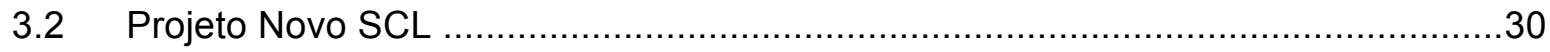

3.3 Proposta de criação do Comercializador Varejista ...............................................31

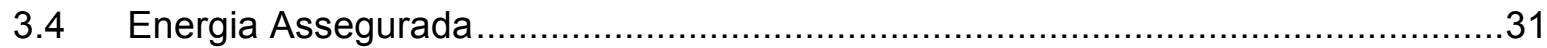

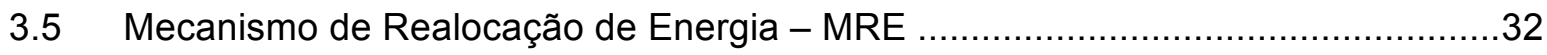

3.5.1 Geração total do MRE maior ou igual o total de Energia Assegurada modulada no sistema

3.5.2 Geração total do MRE menor que o total da Energia Assegurada modulada no

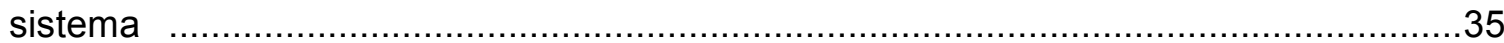

3.5.3 Tarifa de Energia de Otimização - TEO ............................................................

3.6 Mecanismo de Redução de Assegurada - MRA ....................................................

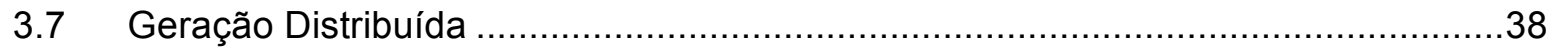

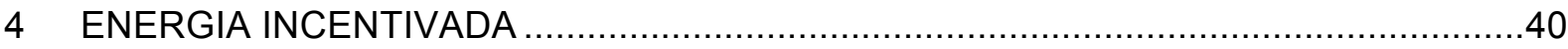

4.1 Aspectos Conceituais e de Comercialização ......................................................40 


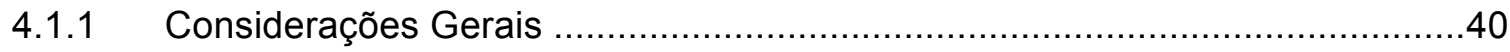

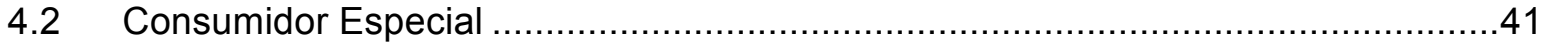

4.2.1 Definições e Regulamentação ......................................................................

4.2.2 Evolução dos Consumidores Especiais .........................................................

4.3 Outros Consumidores de Energia Elétrica .......................................................44

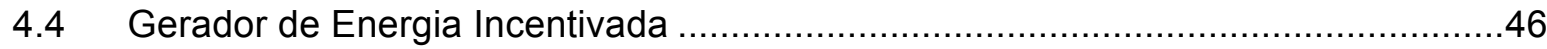

4.5 Sistema de Medição para Faturamento (SMF) .................................................

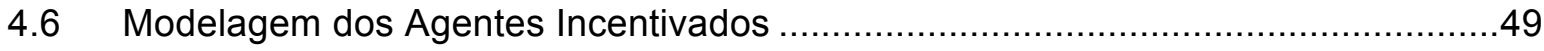

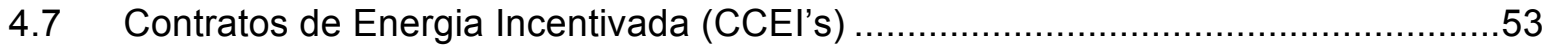

4.7.1 Sazonalização e Modulação dos Contratos Bilaterais .....................................54

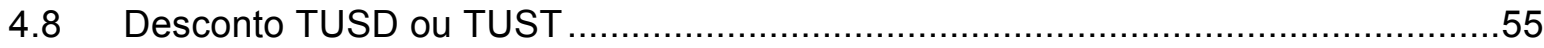

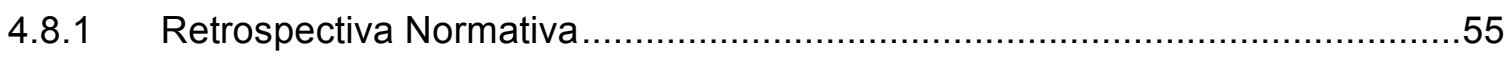

4.8.2 Metodologia de Repasse do Desconto TUSD /TUST ....................................56

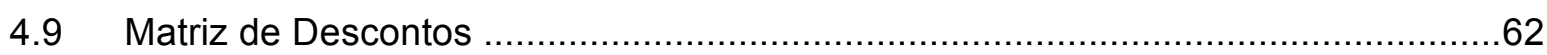

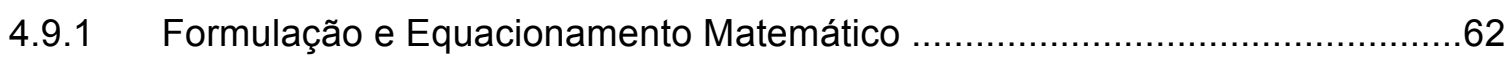

4.9.2 Riscos da Comercialização de Energia Incentivada - Perda dos Descontos ...66

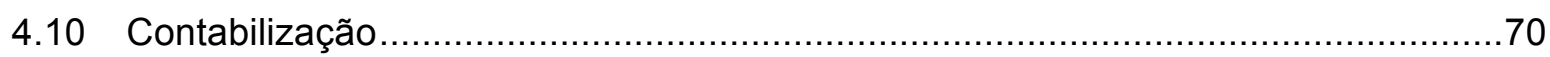

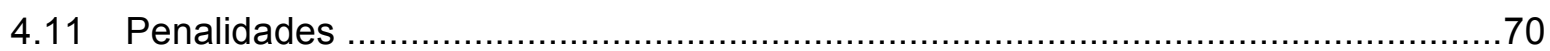

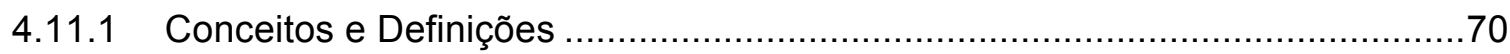

4.11.2 Penalidade por Insuficiência de Cobertura Contratual de Consumo .................71

4.11.3 Penalidade por Insuficiência de Lastro de Venda de Energia (Geradores e

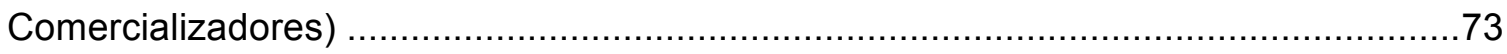

4.12 Venda de Excedentes pelos Consumidores Livres (Especiais) ............................75

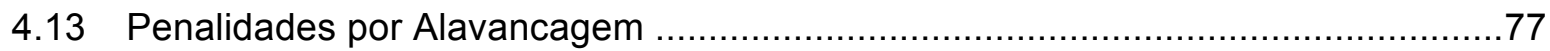

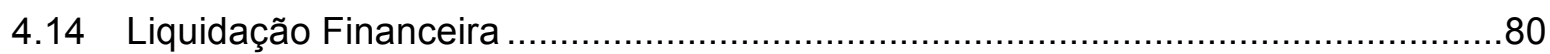

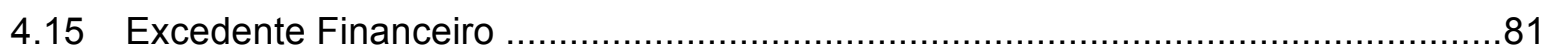

4.16 Certificados de Energia Elétrica - Proposta de criação ......................................83

4.17 Programa de Incentivo às Fontes Alternativas - PROINFA …...............................85

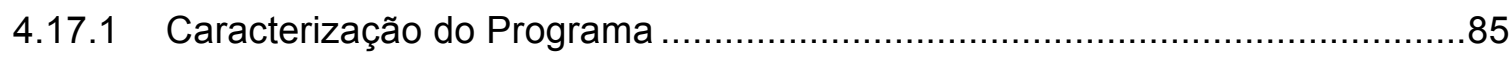

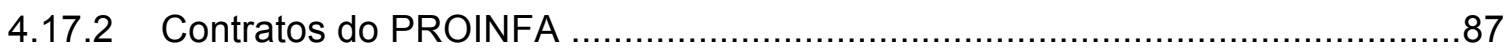

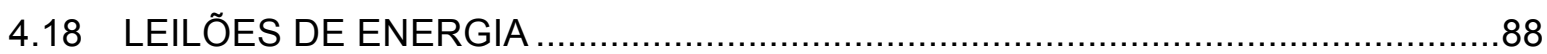

4.18.1 Contratos de Comercialização de Energia no Ambiente Regulado (CCEAR's) ...

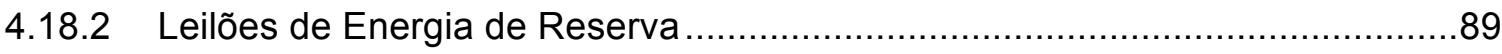

5 ENERGIA INCENTIVADA - UMA VISÃO SUSTENTÁVEL …..................................97

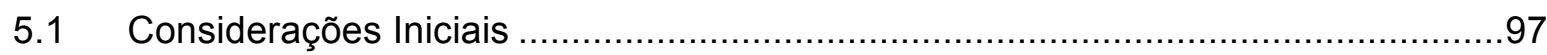




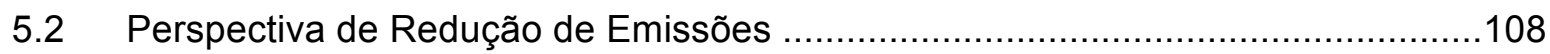

5.2.1 Plano Nacional de Mudança do Clima (PNMC) ….....................................108

5.2.2 Emissões de Gases de Efeito Estufa (GEE) ............................................108

6 COMPLEMENTAÇÃO ENERGÉTICA ENTRE FONTES INCENTIVADAS .................111

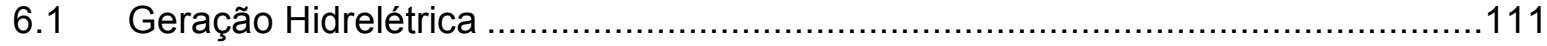

6.2 Caracterização da Complementaridade entre Energia Eólica e a Hidroeletricidade ...

6.3 Análise de Complementaridade de geração entre fontes renováveis de produção sazonal - Geração de Energia Eólica e Termelétricas movidas a Biomassa com PCH's115

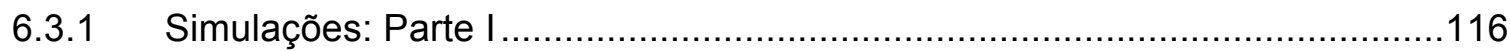

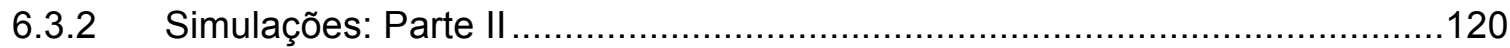

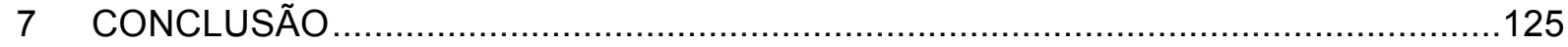

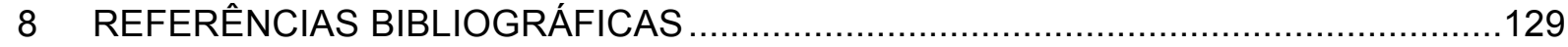

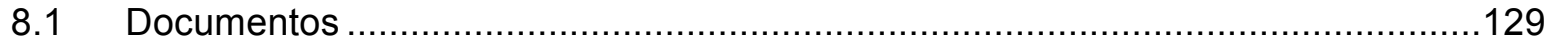

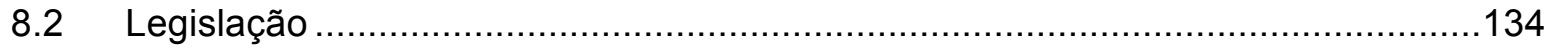

APÊNDICE A - INSTITUIÇÕES DO SETOR ELÉTRICO …......................................139

APÊNDICE B - DADOS DE GERAÇÃO DE ENERGIA EÓLICA - ONS ….......................143

APÊNDICE C - SIMULAÇÕES - COMPLEMENTARIEDADE DE GERAÇÃO ENTRE FONTES RENOVÁVEIS 


\section{INTRODUÇÃO}

\subsection{Sumário dos Estudos Desenvolvidos}

Neste trabalho, apresenta-se uma análise dos aspectos regulatórios e de comercialização de energia elétrica, incorporando a visão de sustentabilidade, no sentido de se sublinhar a relevante questão de como a participação crescente das fontes consideradas incentivadas na matriz elétrica brasileira pode proporcionar benefícios energéticos e de redução nas emissões de gases de efeito estufa, contemplando a proposta para aperfeiçoamentos regulatórios, com especial ênfase nas regras de comercialização.

Nesse âmbito de considerações, apresenta-se inicialmente um breve histórico relacionado à implementação de ajustes do modelo institucional, em 2004. Foram estabelecidos dois ambientes de mercado, quais sejam, o Ambiente de Contratação Regulada (ACR), do qual participam geradoras e distribuidoras, e Ambiente de Contratação Livre $(A C L)$, onde prevalece a livre pactuação de contratos entre geradoras, comercializadoras e consumidores livres.

Ainda com relação aos aspectos regulatórios, cabe esclarecer que o trabalho não trata somente dos aspectos restritos ao âmbito de competência da ANEEL, mas sim, incorpora, todos os aspectos relacionados ao tema da pesquisa levada a termo, independente do órgão onde possa vir a ser tratado, como por exemplo, MME, EPE, CCEE, entre outros citados ao longo do texto.

Com o objetivo específico de promover a ampliação da oferta das fontes alternativas (FA's), destaca-se: (i) a criação do Programa de Incentivo às FA's (PROINFA); (ii) o regramento para a comercialização de Energia Incentivada; (iii) o Mecanismo de realocação de Energia (MRE); (iv) facilidades para compra de Geração Distribuída pelas distribuidoras, para fins de mitigação do risco de variação de mercado; (v) Leilões de Fontes Alternativas e (vii) Leilões de Energia de Reserva (LER).

O objetivo do PROINFA foi aumentar a participação da energia elétrica produzida por Produtores Independentes Autônomos, agente concebido com foco na produção de energia a partir de fontes eólica, Pequenas Centrais Hidrelétricas ( $\mathrm{PCH}$ 's) e 
cogeração a biomassa da cana de açucar, no Sistema Elétrico Interligado Nacional (SIN).

Para contornar as inadequações do PROINFA e criar novas oportunidades para o desenvolvimento da oferta de FA's, foi regulamentada a comercialização de energia incentivada. São considerados Agentes Incentivados (Gerador Incentivado e Consumidor Especial), aqueles que comercializam energia proveniente de biomassa, energia eólica ou solar e PCH's, uma vez verificados alguns condicionantes relacionados ao porte das plantas geradoras em pauta.

A compra e venda de energia incentivada contempla preços livremente negociados entre as partes e é formalizada por meio de Contratos de Compra e Venda de Energia Incentivada (CCEI's).

Um aspecto relevante da regulamentação é a criação de um nicho de mercado específico para as fontes incentivadas, constituído pelos consumidores com demanda contratada entre $500 \mathrm{~kW}$ e $3.000 \mathrm{~kW}$, os quais podem migrar para o mercado livre apenas e tão somente se adquirirem sua energia das referidas fontes incentivadas.

Registre-se, ademais, que os Agentes Incentivados devem comprovar lastro de venda (Geradores e Comercializadores de Energia Incentivada) e Cobertura Contratual de Consumo (Consumidores Especiais) na Câmara de Comercialização de Energia Elétrica (CCEE). Além disso, para complementação do lastro de geração, o Agente Gerador Incentivado (AGI) poderá registrar contratos de aquisição de outras fontes de geração, de até $49 \%$ (quarenta e nove por cento) da sua garantia física.

Os AGl's também tem direito a descontos nos pagamentos das Tarifas de Uso do sistema de Transmissão (TUST) e Tarifas de Uso do Sistema de Distribuição (TUSD). Por outro lado, o comprador de energia incentivada também recebe o desconto nas referidas tarifas, como reflexo do agente vendedor, abrindo espaço para que as FA's possam se apresentar mais competitivas. 
Discute-se ainda, as regras de comercialização da energia incentivada e a formulação da "Matriz de Descontos", que afeta os percentuais de desconto referentes à tarifa de fio, a serem direcionados ao agente que adquira energia na modalidade de "consumidor especial".

Objetivando aumentar a confiabilidade do SIN, foi regulamentada a contratação de energia de reserva, por meio de leilões específicos (Leilões de Energia de Reserva LER). Nesse ponto, os LER são eficientes na contratação de energia eólica e biomassa, em função da regulamentação fixada, em razão das especificidades das regras de comercialização.

Outro aspecto contemplado na análise refere-se ao fato de que, como energia de reserva, a biomassa de cana de açúcar e a energia eólica podem atuar de forma complementar à geração hidrelétrica. O período de safra da cana de açúcar coincide com o período seco anual do sistema elétrico, quando os reservatórios estão normalmente deplecionados, como também a fonte eólica, pelo fato de que, no período seco anual, há mais vento. Assim, a entrada dessas fontes traz um impacto benéfico importante na formação do Preço de Liquidação das Diferenças, que é extremamente sensível ao nível dos reservatórios, contribuindo também para a mitigação do risco de atendimento sistêmico.

A sinergia existente entre as fontes eólica e biomassa e a geração hidrelétrica é discutida na sequência. Nesse âmbito, inclui-se uma aferição do risco de comercialização da Energia Incentivada e como esse risco pode ser mitigado através de "hedge" contratual entre fontes incentivadas.

Dito isto, com o objetivo de avaliar e qualificar a sinergia entre energia eólica e da biomassa, lembrando que ambas tem perfil de produção complementar às Pequenas Centrais Hidrelétricas ( $\mathrm{PCH}$ 's), foram realizadas simulações para identificar a melhor estratégia de contratação de energia, a fim de buscar a máxima receita líquida possível, atendendo restrições de risco.

Outro fator importante a ser considerado é a tendência crescente e preocupante no aumento das emissões de carbono, mesmo com a realização de vários projetos por meio do Mecanismo de Desenvolvimento Limpo (MDL). 
Assim, o incentivo à Energia Incentivada pode ser considerado um relevante fator na redução nos níveis de emissões no setor elétrico, ajudando o país a atingir um desenvolvimento mais sustentável.

Nessa perspectiva, são apresentados resultados de estudos do setor elétrico, realizado pelas instituições do setor elétrico e outros órgãos que comprovam que a complementariedade dessas fontes incentivadas proporciona benefícios energéticos e evita a emissão de gases de efeito estufa.

Também são apresentadas propostas de alterações regulatórias e comerciais que estão sendo discutidas no setor e que ainda não estão aprovadas, porém são consideradas relevantes e impactantes no que diz respeito à energia incentivada, destacando-se a possibilidade de cessão de energia excedente pelos consumidores livres e especiais; a criação de penalidades por alavancagem; a proposta de criação do Comercializador varejista; e dos certificados de energia (CEE's).

Finalmente, cabe considerar que em relação aos aspectos abordados nesse trabalho, que ainda não possuem resultado final por estarem com processo em andamento, será registrada a data de corte de atualização das informações até junho de 2012.

Este trabalho apresenta três apêndices. O primeiro tem o objetivo de complementar o capítulo 2, que trata sobre Comercialização de Energia Elétrica, apresentado as instituições do setor elétrico. O segundo Apêndice tem o objetivo de complementar o capítulo 6.1.1 (Caracterização da Complementaridade entre a Energia Eólica e a Hidroeletricidade), apresentando as informações utilizadas para a geração dos gráficos apresentados. Por sua vez, o terceiro Apêndice tem o objetivo de complementar o capítulo 6.2 (Análise de Complementaridade de geração entre fontes renováveis de produção sazonal - Geração de Energia Eólica e Termelétricas movidas a Biomassa com PCH's), justificando as informações utilizadas para a realização das simulações apresentadas. 


\subsection{Integração dos Assuntos Regulatórios, de Comercialização e Sustentabilidade}

A regulação, abrangendo o conjunto de comandos legais em diversos níveis de hierarquia, tem um papel importante e influencia no funcionamento adequado do setor elétrico, principalmente no que se refere aos aspectos relacionados à comercialização e sustentabilidade.

A regulação, no foco dessa dissertação, concentra, principalmente, a forma de executar as determinações das Leis e Decretos. Sobre a regulação, Maria D’Assunção Costa Menezello, na sua obra “(Agências Reguladoras e o direito Brasileiro - Editora Atlas S.A.), ensina [35]:

"A limitação ao Poder Regulador das agências advém dos limites previstos na Constituição Federal, por meio dos princípios e dos preceitos fundamentais, e na lei de criação de cada uma das agências. Assim, podemos afirmar que regular é, pois, editar atos normativos infralegais com legitimidade $e$ eficácia nos limites outorgados pela lei".

Esses atos normativos, produzidos pelas agências reguladoras, devem seguir igualmente o regime jurídico dos atos emanados pelo resto da Administração Pública, que apresentam os seguintes traços fundamentais:

1) estrita conformidade com a lei; 2) presunção júris tantum de legitimidade; 3) imperatividade; 4) exigibilidade; 5) indisponibilidade do interesse público; 6) dever de motivação; 7) autoexecutoriedade, se, quando e como necessária; 8) possibilidade de contraste pelo Judiciário; 9) possibilidade de revogação, na ocorrência de motivo superveniente; 10) dever de ivalidade, de sanear ou sua manutenção por impedimento do próprio ornamento jurídico.

Em síntese: cada ato normativo ou individual emitido deve ser legal, legítimo, obrigatório, visar ao interesse público, ter motivação necessária e suficiente, ou seja, estar em absoluta concordância com todo o sistema jurídico, incluindo principalmente os princípios constitucionais e legais".

Dito isto, se pode caracterizar que a atividade de comercialização de energia elétrica, representada pelas "regras de comercialização", é suportada por um conjunto de equações matemáticas e fundamentos conceituais, integrantes da regulação existente, que quando associado aos Procedimentos de Comercialização, que são um conjunto de normas que definem condições, requisitos, eventos e prazos relativos à comercialização de energia elétrica, estabelecem as bases necessárias para a operação comercial e estipulam o processo de contabilização e liquidação. 
Ainda, com relação aos aspectos ambientais, o agravamento do efeito estufa, provocado especialmente pelo consumo de recursos energéticos fósseis, hoje reconhecidos como um dos principais responsáveis pelas emissões do setor elétrico, com efeito, potencialmente catastrófico. As mudanças climáticas são, atualmente, o maior problema ambiental do planeta, tratando-se de uma ameaça concreta a ser enfrentada com toda a seriedade.

Assim, a preocupação mundial com a necessidade de preservação ambiental, principalmente com a emissão de gases de efeito estufa, é hoje uma realidade.

O incentivo à energia incentivada pode ser considerado um fator importante na redução dos níveis de emissões do setor elétrico. A regulação do setor elétrico, nessa esfera de consideração, é um aspecto a ser considerado para alavancar o efetivo aproveitamento dessas fontes alternativas de energia, de modo a contribuir com o país, para se atingir um desenvolvimento mais sustentável.

Diversos são os estudos realizados pelos órgãos e associações do setor elétrico que comprovam o crescimento da aplicação das fontes alternativas consideradas incentivadas, proporcionando benefícios energéticos e evitando a emissão de gases efeito estufa.

À luz do exposto, pode-se dizer que os aspectos regulatórios, de comercialização e aplicação das fontes incentivadas estão diretamente relacionados à sustentabilidade, garantindo assim a expansão da oferta de energia elétrica, em montantes adicionais à hidroeletricidade, de forma a atingir, conforme já dito, um desenvolvimento energético mais sustentável. 


\section{COMERCIALIZAÇÃO DE ENERGIA ELÉTRICA}

\subsection{Modelo Insitucional do Setor Elétrico: Retrospectiva Regulatória}

O Modelo Institucional do Setor Elétrico, formulado a partir das bases do Modelo RESEB implantado em 1998 [14], originou-se das Medidas Provisórias MP 143/2003 e MP 144/2003, que foram convertidas nas Leis $n^{\circ} s$ 10.847/2004 e 10.848/2004.

A Lei $n^{\circ}$ 10.848/2004 dispõe sobre a comercialização de energia elétrica mediante contratação regulada ou livre, observadas as regras e procedimentos de comercialização e o Decreto $n^{\circ}$ 5.163/2004 que regulamenta a comercialização de energia elétrica e o processo de outorga das concessões e de autorizações de geração de energia elétrica. Complementando o marco legal estabelecido sob a égide de Leis, a Lei $n^{\circ}$ 10.847/2004 autoriza a criação da Empresa de Pesquisa Energética (EPE).

Nos Diplomas legais citados, fica claro que os principais objetivos do atual Modelo do Setor Elétrico foram promover a modicidade tarifária, garantir a segurança do suprimento; assegurar a estabilidade regulatória e promover a inserção social (universalização de atendimento).

Com o objetivo de complementar este capítulo, no apêndice $A$ deste trabalho são apresentadas as instituições que suportam o funcionamento do Modelo Institucional vigente no Setor Elétrico Brasileiro.

Do ponto de vista mais específico da comercialização de energia elétrica, a Resolução Normativa $n^{\circ}$ 109/2005 estabelece as condições para o exercício dessa atividade e o Decreto $n^{\circ}$ 5.163/2004 expede ainda a Convenção de Energia Elétrica, Regras de Comercialização e os Procedimentos de Comercialização.

Convém ressaltar ainda que a Resolução Normativa $n^{\circ}$ 109/2005 institui a Convenção de Comercialização de Energia Elétrica, estabelecendo a estrutura e a forma de funcionamento da Câmara de Comercialização de Energia Elétrica - CCEE. 


\subsection{Relações Contratuais e Comerciais no Modelo Institucional vigente no Setor Elétrico}

\subsubsection{A natureza do contrato de compra e venda de energia elétrica}

Os contratos de compra e venda são instrumentos comerciais financeiros, cujo único objetivo é reduzir a volatilidade dos pagamentos no mercado de curto prazo. Em outras palavras, um gerador assina um contrato para se proteger contra preços de curto prazo reduzidos, enquanto que os compradores (comercializadores e consumidores livres) tenderão a buscar contratos para se proteger contra preços de curto prazo elevados.

A assinatura de um contrato expõe o gerador a outro tipo de risco, que é o de ser obrigado a comprar energia no mercado de curto prazo a preços elevados para complementar a diferença entre a energia produzida e/ou alocada da parcela de sua energia assegurada comercializada em contrato.

No caso de uma usina térmica, este risco é relativamente pequeno, pois nos períodos de preço de curto prazo elevado a planta estará gerando em sua capacidade máxima e, portanto, atendendo a seu contrato. No caso de uma hidrelétrica, entretanto, este risco é substancial, pois os períodos de preços de curto prazo elevados estão frequentemente associados a períodos de seca, quando sua produção diminui.

\subsubsection{Características de um contrato de energia}

Além de flexibilidade, um contrato de compra e venda de energia elétrica no ACL é caracterizado por três variáveis básicas:

- Preço: valor, em $\mathrm{R} \$ / \mathrm{MWh}$, da energia comercializada;

- Prazo: duração do contrato e data para início da entrega de energia;

- Volume: quantidade de energia a ser comercializada, em MWh.

Adicionalmente, outras características são importantes na formação do preço e avaliação dos riscos do negócio: 
- Início de suprimento: data de início da entrega de energia. É um parâmetro importante, pois define a proximidade entre a data de fechamento do contrato e a de entrega efetiva de energia, com os riscos e incertezas inerentes a este defasamento, impactando de forma significativa no preço do contrato;

- Ponto de entrega: local de entrega da energia, podendo ser na barra da geração, no centro de gravidade ${ }^{1}$ do submercado da geração, no centro de gravidade do submercado da carga ou na barra da carga. Sua importância na formação do preço da energia é relevante à medida que define a quem caberá a cobertura das perdas elétricas (também conhecidas como perdas técnicas) decorrentes do negócio, bem como qual parte estará eventualmente exposta a eventuais diferenças de preços entre submercados.

\subsubsection{Ambientes de Contratação - Definições Básicas}

A Lei $n^{\circ} \mathbf{1 0 . 8 4 8 / 2 0 0 4}$ dispõe sobre a comercialização de energia elétrica mediante contratação regulada ou livre, observadas as regras e procedimentos de comercialização.

O Decreto $n^{\circ}$ 5.163/2004 define que a comercialização de energia elétrica é realizada em dois ambientes: (i) Ambiente de Contratação Regulada (ACR) e (ii) Ambiente de Contratação Livre (ACL), definidos e detalhados a seguir.

Com isso, a comercialização de energia elétrica entre concessionários, permissionários e autorizados de serviços e instalações de energia elétrica, bem como destes com seus consumidores no Sistema Interligado Nacional - SIN acontece nos Ambientes de Contratação Regulada (ACR) ou Livre (ACL).

\subsubsection{Ambiente de Contratação Regulada (ACR)}

No Ambiente de Contratação Regulada (ACR), são realizadas as operações de compra e venda de energia elétrica por meio de contratos bilaterais regulados,

\footnotetext{
${ }^{1}$ Centro de Gravidade é um ponto fictício do sistema (SIN), ou seja, que não necessariamente corresponde a uma barra física, definido de tal forma que as perdas elétricas causadas por geradores e consumidores sejam igualmente divididas.
} 
chamados Contratos de Comercialização de Energia Elétrica no Ambiente Regulado (CCEAR) celebrados entre agentes vendedores (geradores - produtores independentes ou autoprodutores) e agentes compradores (distribuidoras), que participam dos leilões de compra e venda de energia elétrica.

Assim, o ACR é voltado para o suprimento de energia às distribuidoras, no atendimento aos seus mercados cativos, por meio da realização de leilões pela menor tarifa, compreendendo, portanto, a contratação de energia para atendimento aos consumidores regulados (consumo cativo dos distribuidores, ou seja, consumidores residenciais, comerciais e industriais que não atendem aos requisitos para se tornarem livres $^{2}$ ou, ainda que atendam a tais requisitos e não tenham exercido esta opção) por meio de contratos regulados.

Com a realização de leilões por menor preço de energia, os vendedores devem assinar contratos com todas as distribuidoras participantes do leilão em questão (Pool de compra), vide figura 1.

No que se refere ao planejamento da expansão do sistema de geração, o Modelo implantado em 2004, obriga os agentes de consumo (distribuidores, vendedores, autoprodutores e consumidores livres/especiais) a preverem suas necessidades para um horizonte relativamente longo, de cinco anos.

Estas previsões servem para sinalizar a necessidade de construção de usinas, em tempo hábil para que estes empreendimentos possam ser licitados e construídos. Os agentes de geração vencedores destes processos de licitação ganham, além do direito de explorar comercialmente o empreendimento que construirão, contratos de longo prazo (mínimo de quinze anos) de venda de energia, celebrados com os agentes de distribuição.

A modicidade tarifária é proporcionada pela forma de aquisição de energia dos agentes de distribuição, através da licitação que busca o atendimento das

\footnotetext{
${ }^{2}$ De acordo com a Lei 9.074/1995 podem optar livremente pelo fornecedor de energia os consumidores cuja demanda seja maior ou igual a $3 \mathrm{MW}$ e atendidos em nível de tensão a partir de $69 \mathrm{kV}$, se conectados antes de julho de 1995, ou em qualquer nível de tensão, se conectados após esta data. Consumidores cuja demanda seja maior ou igual a $500 \mathrm{~kW}$, em qualquer nível de tensão, também podem optar pela compra de energia a partir de fontes alternativas, de acordo com a lei $9.427 / 1996$.
} 
necessidades de contratação pela menor tarifa possível, resultante de competição entre os agentes vendedores, tal como ilustrado na figura 1.

Há uma segmentação do mercado das distribuidoras de forma que:

- os novos empreendimentos (energia nova) deverão ser comercializados para atender à expansão do mercado, mediante licitações que se realizarão em cinco ou três anos antes da data de início de entrega da energia elétrica, por meio de contratos com duração de 15 a 35 anos;

- os empreendimentos existentes serão comercializados exclusivamente para atender à demanda atual, mediante contratos com duração de 3 a 15 anos em licitações realizadas com um ano de antecedência.

A justificativa de segmentação é a de que a energia gerada por usinas existentes (energia "velha") e, teoricamente, já amortizadas, poderia ser comercializada por preços menores do que aquela gerada pelas novas usinas, cujos preços tenderiam ao Custo Marginal de Expansão (CME) $)^{3}$.

\subsubsection{Ambiente de Contratação Livre (ACL)}

No Ambiente de Contratação Livre (ACL), são realizadas operações de compra e venda de energia elétrica, por meio de contratos bilaterais livremente negociados (preço, volume, período de suprimento, garantias e flexibilidade) entre os agentes geradores, comercializadores, consumidores livres, importadores e exportadores de energia, respeitadas as regras e procedimentos de comercialização de energia elétrica. Em maior detalhe, pode-se estatuir que o Ambiente de Contratação Livre - ACL compreende a contratação de energia para atendimento aos consumidores livres, por intermédio de contratos livremente negociados.

\footnotetext{
${ }^{3} \mathrm{O}$ CME representa o acréscimo de custo para suprir um aumento unitário na demanda considerando ajustes no programa de obras, ou seja, representa a expectativa de custo da expansão do parque de geração de energia elétrica. Na hipótese de expansão ótima e contínua, o CME será o custo do empreendimento obtido da curva de custo de expansão, que torna indiferente construir o projeto ou operar o sistema a fim de atender à demanda adicional.

Além de ser empregado como critério no Plano Decenal de Expansão de Energia - PDE, o CME também é utilizado em outros estudos do setor elétrico, tais como os cálculos da garantia física de energia dos empreendimentos de geração e nos estudos de expansão da transmissão, para valoração das perdas elétricas.
} 
Neste ambiente podem participar todos os geradores, comercializadores e consumidores livres, com total liberdade para negociarem seus contratos de compra e venda de energia. A figura 2, a seguir, ilustra a convivência entre os ambientes.

De maneira geral, o Novo Modelo do Setor Elétrico foi concebido com a preocupação de estabelecer um marco regulatório estável de forma a atrair investimentos na expansão do sistema de geração, garantir níveis confiáveis de suprimento e proporcionar modicidade tarifária.

Tal como apresentado, a figura 1, a seguir, representa uma visão geral das relações contratuais entre o Ambiente de Contratação Regulada (ACR) e o Ambiente de Contratação Livre (ACL).

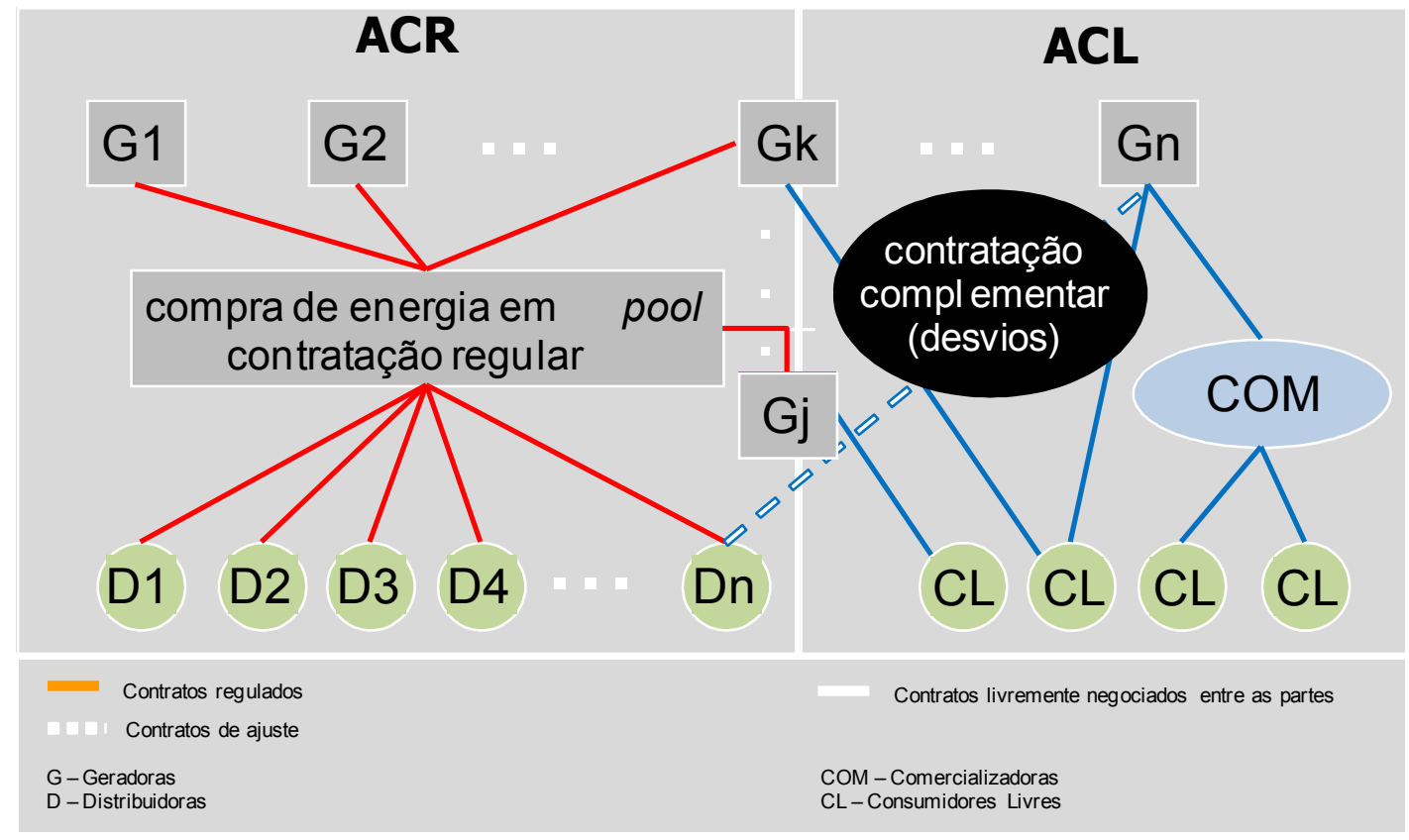

Figura 1: Visão Geral das Relações Contratuais.

Fonte: Cartilha MME: Modelo Institucional do Setor Elétrico [37].

Já a figura 2, a seguir, representa a convivência entre os dois ambientes ACR e ACL: 


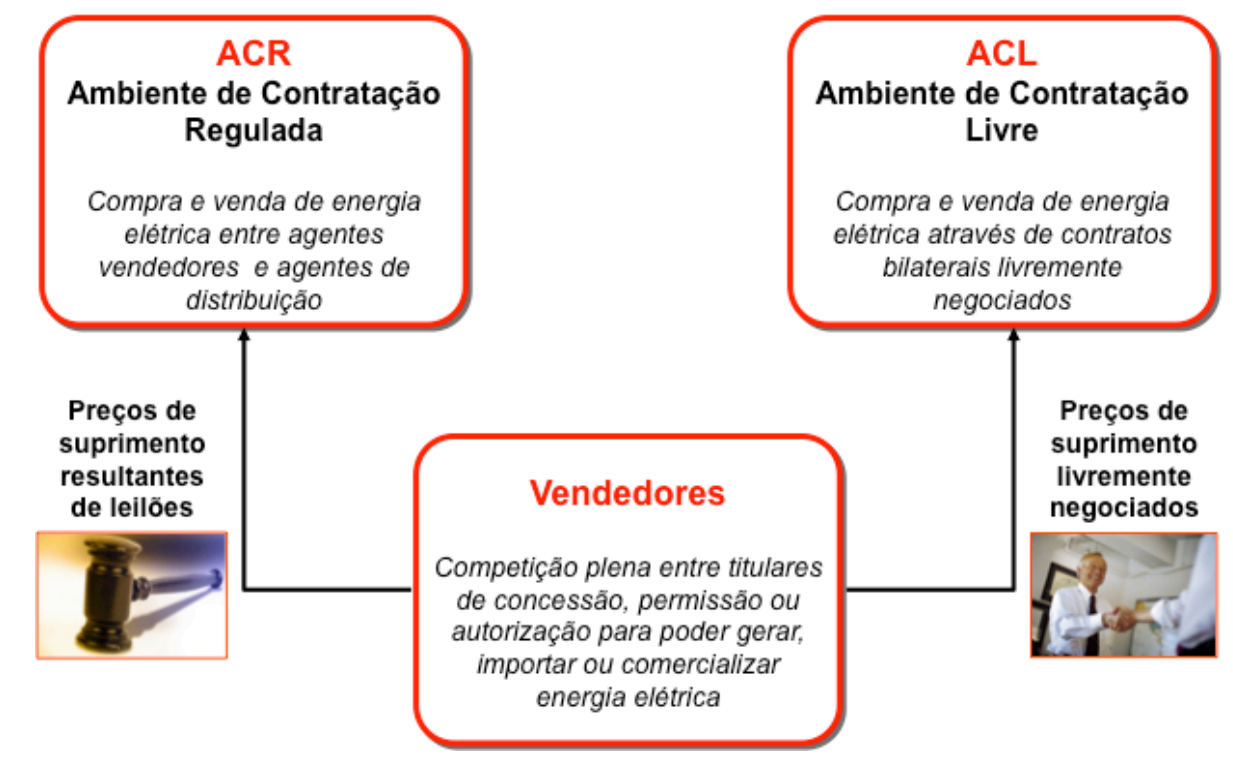

Figura 2: Esquema dos Ambientes de Contratação.

Fonte: PEA 5916 e PEA 5917 - "Formação de Preços e Comercialização no Mercado de Energia Elétrica" [36].

\section{3 mercado de curto prazo}

Como a energia elétrica tem a característica de não ser armazenável em grandes quantidades e de forma economicamente viável, o balanço produção-consumo deve ser feito instantaneamente, de tal forma que, em geral, subsistem diferenças entre o volume contratado e o consumido.

Essa diferença deve ser liquidada no mercado de curto prazo, valorado a um preço que reflita o custo marginal de operação do sistema. Nessa perspectiva, o objetivo do Mercado de Curto Prazo é a contabilização e a liquidação de diferenças entre os montantes de energia contratados e os efetivamente consumidos ou produzidos pelos agentes.

Esta atividade é realizada mensalmente, tendo como base o Preço de Liquidação de Diferenças (PLD) que é publicado antecipadamente pela CCEE. O cálculo do PLD leva em conta a otimização do uso dos recursos eletro-energéticos para atendimento das cargas do sistema e observa limites máximos e mínimos estabelecidos pela ANEEL. 
O custo marginal de operação do sistema elétrico é, de forma simplificada, dado pela usina térmica mais cara despachada por motivos energéticos ou pelo valor da água naquele instante. É obtido através da utilização de uma cadeia de aplicativos de otimização do sistema (Newave e Decomp, desenvolvidos pelo CEPEL).

O valor máximo do PLD (“teto" ou "cap") é definido com base no custo variável de operação da geração térmica mais cara disponível para participar do despacho centralizado. O valor mínimo do PLD ("piso" ou "floor") é estabelecido pela ANEEL, contemplando os custos da operação e a manutenção das usinas hidrelétricas e as compensações financeiras pelo uso dos recursos hídricos [14].

No curto prazo, a condição mais econômica se obtém garantindo a máxima utilização da energia de fonte hidrelétrica disponível, pois isto minimiza os custos de combustível. Não obstante, a utilização dos recursos hídricos no presente provoca um risco maior de déficit no abastecimento futuro.

Por outro lado, a manutenção dos altos níveis dos reservatórios, que permite um grau maior de confiabilidade no abastecimento futuro, através do uso de energia elétrica proveniente de fonte térmica, provoca um aumento no custo de operação imediato.

É com base nessas premissas, analisando a condição presente e a previsão da situação futura, considerando geração hidrelétrica, térmica e a transferência de energia entre regiões, que o ONS elabora o Planejamento da Operação do Sistema Interligado Nacional. Cumpre destacar, que este planejamento não é tão simples de se efetivar, haja vista que os dados futuros são associados ao período de cinco anos a frente e são obtidos com base em dados simulados. Portanto o fator incerteza é condicionante nesse horizonte de planejamento, conforme ilustrado na Figura 03.

Em um determinado estágio de tempo, o dilema da decisão é de utilizar a água dos reservatórios, reduzindo a geração térmica no curto prazo, arriscando-se a ocorrência de um período seco em futuro próximo e de se ter que recorrer a um racionamento, muito mais profundo do que aquele que seria necessário se água tivesse sido poupada. Por outro lado, o operador pode optar pela geração térmica imediata, com custos elevados a serem repassados aos consumidores, arriscando- 
se às críticas da sociedade se um período de chuvas vier a ocorrer, provocando vertimento e mostrando que o custo com o despacho térmico foi desperdiçado.

Para auxiliar a tomada de decisão, utiliza-se um modelo computacional baseado em programação dinâmica estocástica dual, que avalia em base científica a solução de compromisso entre uma condição de armazenamento no sistema e uma tendência hidrológica, comparando as opções de despachos térmicos no presente, preservando a água nos reservatórios, versus não gerar termelétricas e utilizar a água que poderia substituir o despacho de térmicas caras e racionamento futuro.

Antigamente, a competência das simulações para definição do preço de curto prazo era do $A S M A E / M A E{ }^{4}$ e hoje em dia a responsabilidade é da CCEE, utilizando os mesmos modelos computacionais, para ajustar o planejamento elaborado pelo ONS, retirando as restrições de transmissões internas de cada submercado e a energia vinculada às usinas em teste, pelo que, dessa forma, a energia comercializada passa a ser tratada como igualmente disponível em todo o submercado, permitindo que seja apurado apenas um único preço para toda a região que caracteriza o submercado.

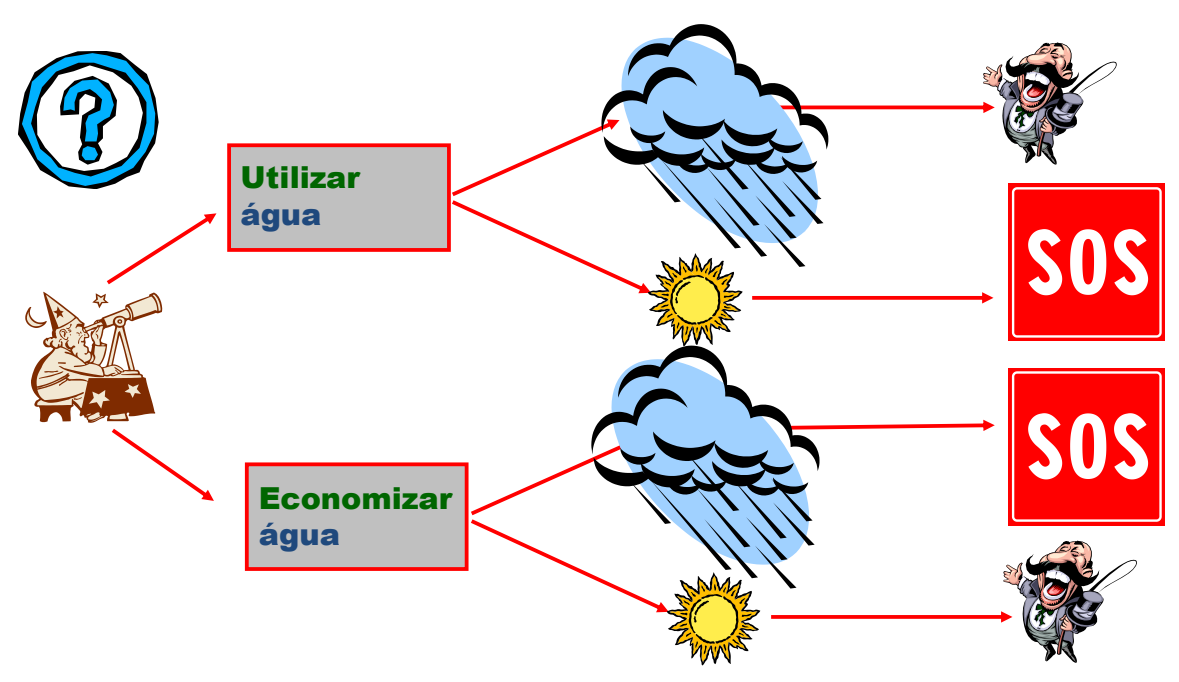

Figura 3: Planejamento da Operação.

Fonte: PEA 5916 e PEA 5917 - "Formação de Preços e Comercialização no Mercado de Energia Elétrica" [36].

\footnotetext{
${ }^{4}$ ASMAE: Administradora de Serviços do MAE.
} 
Não obstante, na prática, a disponibilidade de energia varia dentro do submercado. Isto pode resultar em uma geração verificada diferente da geração planejada. Esta diferença é tratada por meio de Encargos de Serviços de Sistema ${ }^{5}$.

Em um primeiro momento o $\mathrm{CMO}$ foi determinado mensalmente, utilizando-se apenas o modelo computacional NEWAVE. Durante este período estavam em vigor as Regras de Mercado, versão 2.2, onde o Preço MAE era o maior valor entre o CMO e o CUSTO_MRE ${ }^{6}$. Vale a pena ressaltar ainda que, o CMO não é utilizado na apuração do preço.

\subsection{A regulamentação das relações contratuais e comerciais}

Em 30 de julho de 2004 foi assinado o Decreto 5.163/2004, ainda vigente, regulamentando a Lei $\mathbf{1 0 . 8 4 8 / 2 0 0 4}$, que trata da comercialização de energia elétrica e do processo de outorga de concessões e de autorizações de geração de energia elétrica. O citado Decreto está dividido em seis capítulos, sendo que o capítulo 2 está subdividido em cinco seções:

1. Regras Gerais de Comercialização de Energia Elétrica

2. Comercialização de energia no Ambiente de Contratação Regulada

Seção 1 - Disposições Gerais

Seção 2 - Informações e Declarações de Necessidades de Energia Elétrica

Seção 3 - Leilões para Compra de Energia Elétrica

Seção 4 - Contratos de Compra e Venda de Energia Elétrica

Seção 5 - Repasse às Tarifas dos Consumidores Finais

3. Comercialização de energia do Ambiente de Contratação Livre

4. Contabilização e Liquidação de Diferenças no Mercado de Curto Prazo

5. Outorgas de Concessão

6. Disposições Finais e Transitórias

\footnotetext{
${ }^{5}$ Encargos de Serviços do Sistema - Consistem na apuração dos custos incorridos aos geradores na manutenção da confiabilidade e estabilidade do sistema ressarcido via pagamento por parte dos consumidores (MAE, 2002).

${ }^{6}$ O CUSTO_MRE será detalhado mais adiante.
} 
Nesse contexto, nos próximos tópicos deste e do próximo capítulo, passa-se ao detalhamento dos Artigos e Incisos dos capítulos que mais impactam nas estratégias de comercialização de energia dos agentes do mercado.

\subsection{Lastro Contratual}

No regramento da comercialização, foram estabelecidos os dois princípios básicos para a segurança do suprimento:

- Todo agente de consumo está obrigado a contratar $100 \%$ de sua carga;

- Cada contrato de venda de energia deve ter um lastro físico de geração, de forma que não existam contratos sem a correspondente capacidade de suprimento.

O Decreto 5.163/2004 estabelece ainda, as diretrizes para as distribuidoras, para a aferição do atendimento - contratar $100 \%$ das cargas (no caso da energia, verificada anualmente no mês de janeiro sobre o consumo ocorrido nos últimos doze meses) e remete as penalidades por não-cumprimento à Convenção de Comercialização da Câmara de Comercialização de Energia Elétrica - CCEE.

No caso do lastro físico de geração, o Decreto determina que o lastro de cada empreendimento constará do respectivo contrato de concessão ou ato de autorização. Finalmente, este mesmo capítulo do Decreto em foco, estabelece o tratamento a ser dado quando o empreendimento de geração que serve de lastro para um contrato não é concluído a tempo, ou quando sofre indisponibilidade prolongada. Nestes casos, o responsável pelo empreendimento terá a obrigação de recompor o lastro físico de seus contratos de venda de energia, sem prejuízo de penalidades estabelecidas pela ANEEL.

\subsection{Comercialização no ACR}

\subsubsection{Disposições Gerais}

Esta seção especifica que para cumprir a obrigação de atendimento a $100 \%$ de sua carga, os distribuidores devem utilizar as seguintes formas de contratação: 
- Leilões de compra de energia, a saber:

$\checkmark$ Leilões de energia proveniente de novos empreendimentos de geração;

$\checkmark$ Leilões de compra de energia proveniente de empreendimentos existentes;

$\checkmark$ Leilões de ajuste (nos quais também é adquirida energia proveniente de empreendimentos existentes).

- Aquisição de energia de geração distribuída.

Além disto, no cumprimento dessa obrigação, serão também considerados os contratos decorrentes de:

- Energia contratada na primeira etapa do PROINFA - Programa de Incentivo às Fontes Alternativas de Energia Elétrica;

- Aquisições anteriores à Lei $n^{0}$ 10.848/2004 (ou seja, firmados antes de 16 de março de 2004);

- Energia proveniente de Itaipu Binacional; e

- Compra de energia do supridor atual com tarifas reguladas (somente para distribuidoras de pequeno porte, com mercado inferior a $500 \mathrm{GWh} / \mathrm{ano}$ ).

O Decreto define o que é energia proveniente de novos empreendimentos e estabelece que o MME deve apresentar a lista de empreendimentos de geração aptos a participar dos leilões de novos empreendimentos, a partir de estudos da Empresa de Pesquisa Energética - EPE - e de ofertas de investidores. Também define geração distribuída e determina que sua contratação deva ser precedida de chamada pública e estará limitada, no total, a $10 \%$ da carga do distribuidor.

O preço teto de repasse estará limitado ao Valor Anual de Referência - VR, que é uma média ponderada dos custos de aquisição de energia nos leilões de "A-3" e "A5", realizados a 3 anos e 5 anos do ano alvo, respectivamente, calculado para o conjunto de todas as distribuidoras.

\subsubsection{Declarações de Necessidades}

Esta seção apresenta duas regras básicas: 
- Todo agente distribuidor, vendedor, autoprodutor ou consumidor livre tem a obrigação de declarar, em cada ano, sua previsão de mercado ou carga, para cada um dos cinco anos subseqüentes. Esta declaração será utilizada no planejamento da expansão do sistema;

- Cada agente de distribuição deve declarar, até sessenta dias antes de cada leilão de energia proveniente de empreendimentos existentes ou de energia proveniente de novos empreendimentos, os montantes de energia que deverá contratar nos leilões. Esta declaração, bem como a expectativa de redução dos contratos de energia existente, são os objetos de simulação do modelo desenvolvido.

\subsubsection{Leilões para Compra de Energia Elétrica}

Os leilões de energia estabelecem o valor adequado ao equilíbrio do preço com a percepção do risco, porém de forma a estabelecer um preço teto coerente com a prática da modicidade tarifária.

A Lei $n^{\circ}$ 10.848/2004 em seu artigo $n^{0} 2$ estabelece que as concessionárias, permissionárias e autorizadas de serviço público de distribuição de energia elétrica do SIN, devem garantir o atendimento à totalidade de seu mercado, mediante contratação regulada, por meio de licitação (realização de leilões).

Os leilões para contratação de energia elétrica são regulados e realizados pela ANEEL, podendo ser promovidos por intermédio da CCEE (artigo $\mathrm{n}^{\circ} 2$ e parágrafo 11 da Lei $n^{\circ}$ 10.848/2004).

De acordo com o Decreto $n^{\circ} \mathbf{5 1 6 3 / 2 0 0 4}$, artigo $n^{\circ} 20$ e inciso IV, deve ser utilizado o critério de menor tarifa para a definição de vencedor de um leilão, sendo os vencedores aqueles que ofertarem energia elétrica pelo menor preço, expresso em $\mathrm{R} \$$ por $\mathrm{MWh}$, para atendimento à demanda das distribuidoras em acordo com a Lei $n^{\circ} \mathbf{1 0 . 8 4 8 / 2 0 0 4}$ em seu artigo $n^{\circ} 2$. 
Os Contratos de Comercialização de Energia Elétrica em Ambiente Regulado (CCEAR) serão, então, celebrados entre os agentes vendedores que lograrem vender ao final do leilão e as Distribuidoras que declararam necessidade de compra para o ano de início de suprimento da energia contratada no leilão.

$\mathrm{Na}$ mesma seção define-se ainda as opções para compra de energia elétrica no ACR, quais sejam leilões de:

i. energia proveniente de novos empreendimentos, realizados cinco anos antes do início da entrega da energia - chamados de leilões "A-5";

ii. energia proveniente de novos empreendimentos, realizados três anos antes do início da entrega - leilões "A-3";

iii. energia de empreendimentos existentes, realizados no ano anterior ao de início da entrega da energia - leilões "A-1"; e

iv. ajustes, também de energia proveniente de empreendimentos existentes, com início de entrega em até 4 meses.

Os editais de cada leilão definem os prazos de duração de cada contrato. No caso dos leilões "A"-1, o prazo de suprimento é no mínimo de 03 (três) anos e no máximo 15 (quinze) anos, para os leilões "A"-3 e "A"-5 o prazo é de no mínimo 15 (quinze) anos e no máximo 30 (trinta) anos de suprimento e, para os leilões de Ajuste, a duração máxima é de 2 anos.

A figura 4 a seguir ilustra os diversos momentos em que uma distribuidora pode recorrer à contratação de energia.

O MME tem por atribuição definir o preço máximo de aquisição nos leilões de energia proveniente de empreendimentos existentes. A partir de 2009, o preço máximo não poderá superar o valor médio resultante dos leilões de compra de energia elétrica proveniente de novos empreendimentos realizados no ano "A-5", cujo início de suprimento coincida com o ano do leilão de "A-1".

Um ponto importante a acrescentar é que o MME homologa a quantidade de energia a ser contratada nos leilões de energia elétrica, bem como aprova a relação dos novos empreendimentos que integrarão os leilões para a contratação de energia. 


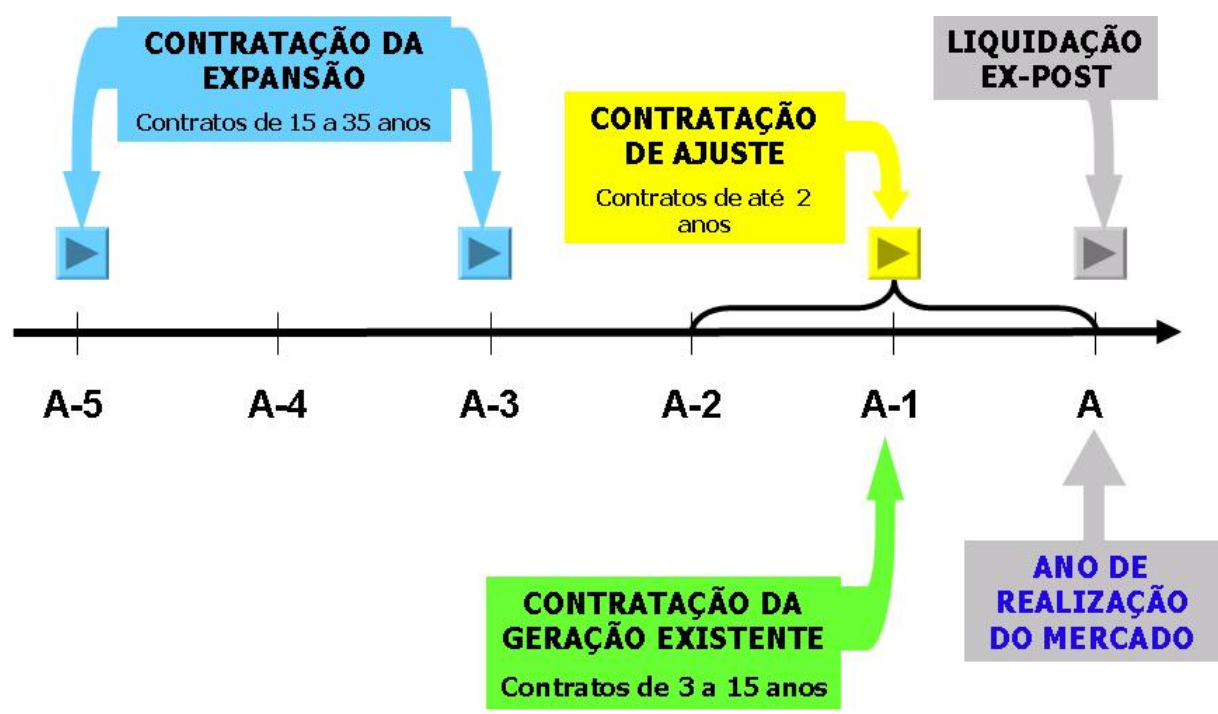

Figura 4: Opções de contratação das distribuidoras.

Fonte: PEA 5916 e PEA 5917 - "Formação de Preços e Comercialização no Mercado de Energia Elétrica" [36].

Adicionalmente, é estabelecido que os editais dos leilões sejam elaborados pela ANEEL, observando diretrizes do MME, notadamente:

- a utilização do critério de menor tarifa no julgamento;

- o valor do pagamento anual pelo Uso do Bem Público - UBP, no caso de novas concessões de aproveitamentos hidrelétricos;

- o detalhamento das condições de participação de empreendimentos que entraram em operação a partir de 2000 nos leilões de energia proveniente de novos empreendimentos;

- a definição do tratamento a ser dado, nos leilões de energia proveniente de novos empreendimentos, às usinas que obtiveram suas concessões com base em máximo pagamento de UBP, com o objetivo de compensar uma eventual desvantagem dessas usinas numa licitação por menor tarifa;

- o limite máximo para a quantidade de energia adquirida pelas distribuidoras nos leilões de energia proveniente de empreendimentos existentes. Este limite (105\% da reposição dos contratos da distribuidora que estejam vencendo) evita que as distribuidoras adquiram no futuro energia proveniente de empreendimentos existentes no lugar de energia proveniente de novos empreendimentos que seria 
necessária para atender à expansão do sistema, o que poderia comprometer a segurança do suprimento;

- as regras para os leilões de energia provenientes de empreendimentos existentes durante o período de transição. O objetivo é permitir que a energia descontratada devido ao excesso conjuntural de oferta em relação à demanda tenha a oportunidade de ser contratada pelas distribuidoras, proporcionando maior tranqüilidade aos geradores e contribuindo para o funcionamento normal do modelo desde seu início de implantação;

- energia de origem hidrelétrica contratada na modalidade "contratos de

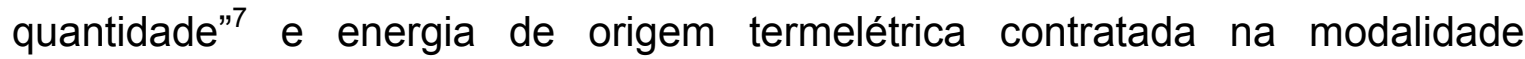
"contratos de disponibilidade" ${ }^{8}$. Em ambos os casos, a entrega será sempre no Centro de Gravidade do submercado onde esteja localizado o empreendimento de geração, de forma que os riscos impostos por diferenças de preços entre submercados ficam alocados às Distribuidoras, com direito de repasse aos consumidores finais ${ }^{9}$;

- o limite máximo para o total de energia contratada pela distribuidora em leilões de ajuste (1\% da carga da distribuidora), para impedir que o distribuidor opte por não contratar energia proveniente de novos empreendimentos que poderia levar ao desabastecimento.

Define-se ademais disso, uma fórmula que permite a participação nos leilões, em igualdade de condições, de investidores que pretendam utilizar parte da energia do empreendimento hidrelétrico leiloado para uso próprio ou para comercialização no ACL e outra parte destinada ao suprimento do consumidor cativo do ACR.

\footnotetext{
${ }^{7}$ Contratos por "quantidade de energia" são aqueles nos quais o agente vendedor assume os riscos hidrológicos.

${ }^{8}$ Contratos por "disponibilidade de energia" são aqueles nos quais os agentes compradores assumem os riscos hidrológicos (e com isto podem adquirir energia por um preço mais reduzido). Em outras palavras, o custo de combustível e os custos variáveis de operação da termelétrica são assumidos diretamente pelos compradores, que se beneficiam da operação em complementação térmica, em períodos hidrológicos favoráveis, bem como assumem os custos de operação na base em períodos hidrológicos adversos. A receita do contrato de disponibilidade, para o vendedor, objetiva tão somente remunerar os investimentos realizados e cobrir os custos de operação e manutenção fixos, caracterizando, desse ponto de vista, um contrato de "leasing" das instalações.

${ }^{9}$ Exceto nos contratos dos leilões de ajuste, onde a entrega será no centro de gravidade do submercado do comprador.
} 
A fórmula objetiva incentivar o investidor a destinar mais energia ao mercado regulado, o $A C R$, proporcionando um ganho a ser utilizado em benefício da modicidade tarifária.

\subsubsection{Leilões de Fontes Alternativas}

Os Leilões de Fontes Alternativas caracterizam uma estratégia do Governo Federal de dar continuidade à política de ampliação da participação das fontes alternativas renováveis na matriz brasileira, em conformidade com a política setorial de incentivo às fontes renováveis, iniciada com o PROINFA.

O Decreto $n^{\circ}$ 6.048/2007 altera o Decreto $n^{\circ} 5.163 / 2004$ e regulamenta os Leilões de Energia de Fontes Alternativas.

"Art. 11 (...) § 20 A energia elétrica decorrente de importação e a gerada por meio de fontes alternativas, salvo o disposto no $\S 40$, serão consideradas como provenientes de empreendimentos de geração novos ou existentes, conforme previsto no $\S 10$ deste artigo. (...)

$\S 4^{\circ}$ Excepcionalmente, para cumprimento à obrigação de atendimento de cem por cento da demanda dos agentes de distribuição, a ANEEL poderá, de acordo com as diretrizes do Ministério de Minas e Energia, promover direta ou indiretamente leilões de compra de energia proveniente de fontes alternativas, independentemente da data de outorga." (NR)"

\subsubsection{Contratos de Compra e Venda de Energia no Ambiente Regulado}

Esta seção determina que os vencedores de cada leilão de energia do ACR deverão firmar contratos bilaterais com todas as distribuidoras que estejam adquirindo energia no leilão em tela, contratos esses denominados Contratos de Comercialização de Energia em Ambiente Regulado, CCEAR, com volumes definidos em proporção às respectivas declarações de necessidade. A única exceção era o leilão de ajuste, onde os contratos eram específicos entre agente vendedor e agente de distribuição; esta característica foi alterada desde o $10^{\circ}$ leilão de ajuste, realizado em fevereiro de 2011.

São especificadas as durações mínima e máxima para os CCEAR provenientes dos leilões "A-5" ou "A-3" (15 a 30 anos) e "A-1" (3 a 15 anos) e estabelecida existência de cláusula arbitral. Excepcionalmente para os leilões da transição promovidos pela 
ANEEL em 2004 e 2005, a seção anterior definiu que o prazo mínimo de vigência dos contratos de compra de energia elétrica proveniente de empreendimentos de geração existentes seria de oito anos para o início do suprimento a partir de 2005 , 2006 e 2007 e de no mínimo cinco anos para o início do suprimento a partir de 2008 e 2009 (fase de transição do modelo).

Para os CCEAR decorrentes de leilões de energia proveniente de empreendimentos existentes, o Decreto estabelece três possibilidades de redução das quantidades contratadas:

- compensação pela saída de consumidores potencialmente livres - os distribuidores, após utilizarem o mecanismo de compensação de sobras e déficits (mecanismo que faz parte da Convenção de Comercialização), poderão reduzir seus contratos no montante equivalente ao saldo não compensado devido à saída do consumidor livre;

- redução, a critério da distribuidora, de até $4 \%$ do montante contratado para adaptar-se aos desvios do mercado face às projeções de demanda; e

- adaptação às regras estipuladas nos contratos de geração pactuados até 11 de dezembro de 2003.

Nos três casos, as reduções devem ser aplicadas uniformemente entre todos os CCEAR da distribuidora, decorrentes de leilões de energia proveniente de empreendimentos existentes.

\subsubsection{Repasse às Tarifas}

Esta seção apresenta as condições de repasse dos custos de aquisição de energia às tarifas dos consumidores finais. Definiu-se também um mecanismo para "indução de eficiência" na contratação das distribuidoras, recentemente revogado.

Considerando que os contratos resultam de leilões, poderia parecer, à primeira vista, que todos os custos de aquisição de energia deveriam ser automaticamente repassados às tarifas dos consumidores finais. Entretanto, como a quantidade de energia que cada distribuidora adquire em cada tipo de leilão é uma decisão da própria distribuidora, os mecanismos de repasse passam a ser indutores à contratação eficiente. 
$\mathrm{O}$ primeiro mecanismo ${ }^{10}$ se caracterizava pelo repasse de um valor único para compensar os custos de aquisição da energia proveniente de novos empreendimentos das distribuidoras, o VR. Como conseqüência, a distribuidora que tivesse um custo individual de contratação de energia proveniente de novos empreendimentos inferior a esta "média do mercado" teria um ganho. O VR caracterizava um estímulo para contratação eficiente em "A-5", cujo custo de aquisição deveria, na maioria das situações, ser inferior ao da energia contratada em "A-3".

O VR seria aplicado nos três primeiros anos de vigência dos contratos de energia proveniente de novos empreendimentos. A partir do $4^{\circ}$ ano, os custos individuais de aquisição seriam repassados integralmente.

O VR também é usado como limite máximo para repasse dos custos de aquisição de energia proveniente de empreendimentos existentes nos leilões de ajuste e para a contratação de geração distribuída. Ainda com o objetivo de induzir a contratação eficiente, existem as seguintes limitações ao repasse:

- A distribuidora pode repassar os montantes contratados até $103 \%$ de sua carga. Este limite pretende aumentar a segurança do sistema, pois reconheceria a impossibilidade de uma previsão perfeita da demanda e estabeleceria um limite aceitável para erros nesta projeção, assegurando que os contratos sejam no mínimo iguais à carga;

- Quando a contratação em "A-3" exceder de $2 \%$ da demanda, o direito de repasse está limitado ao menor dentre os custos de contratação relativos a "A-5" e "A-3";

- Se uma distribuidora contratar energia proveniente de novos empreendimentos em excesso para, posteriormente, ajustar-se descontratando energia proveniente de empreendimentos existentes, provocará uma ineficiência no uso de recursos do país, pois poderia demandar uma expansão antes do prazo de sua real necessidade, "desotimizando" o sistema. Com o objetivo de inibir esta prática, caso a aquisição de energia proveniente de empreendimento existente seja menor que o limite inferior de contratação, o repasse do custo de aquisição de

\footnotetext{
${ }^{10}$ Revogado em 2011 pelo Decreto no 7.521, de 08 de julho de 2011.
} 
energia proveniente de novos empreendimentos correspondente a esse valor não contratado será limitado por um redutor.

- No período de transição, de 2005 a 2008, a contratação de energia proveniente de empreendimentos existentes nos leilões "A-1" não poderia exceder a $1 \%$ da demanda, porque todos os leilões deveriam ocorrer em 2004. O que exceder-se a este limite seria o repassado via dispositivo de custo de aquisição reduzido. Este mecanismo tinha por objetivo incentivar as distribuidoras a contratar o máximo de suas necessidades no leilão de energia proveniente de empreendimentos existentes durante a transição, realizado em 2004, conforme antes explicado.

O limite inferior de contratação é o valor positivo resultante da seguinte equação:

$$
L I=M R-0,04 . M I
$$

Limite Inferior de Contratação

Onde:

Ll é o limite inferior de contratação

MR é o montante de reposição (quantidade de energia dos contratos que se extinguirem no ano do leilão, subtraídas as reduções)

MI é o montante inicial de energia elétrica dos CCEAR considerado para a apuração do MR.

À época, o MME sinalizava que com o objetivo de manter a neutralidade dos repasses dos custos de aquisição de energia das distribuidoras, componentes da Parcela A da tarifa, a ANEEL poderia adotar, levando em conta os doze meses subseqüentes, metodologia de cálculo para o reajuste tarifário, considerando o preço médio ponderado dos contratos de compra.

Além disso, tendo em vista a mudança na metodologia de reajuste e ainda com o objetivo de manter a neutralidade dos repasses de custos componentes da Parcela A, as variáveis resultantes dos custos de aquisição de energia elétrica, não consideradas no reajuste tarifário anterior, seriam contempladas nos mecanismos de compensação, a chamada CVA - Conta de Compensação dos Valores da Parcela A. 
Durante o ano de 2005, todas as Distribuidoras foram chamadas a assinar aditivos ao Contrato de Concessão, contendo cláusulas que contemplam os contratos de leilão em antecipação nas tarifas, no momento do reajuste, sendo que os contratos bilaterais não provenientes de leilão fazem jus à CVA.

Ademais, a ANEEL deveria, a partir de janeiro de 2006, contemplar no reajuste ou revisão tarifária, a previsão dos custos com Encargos de Serviço de Sistema, outro componente da Parcela $A$, para os doze meses subseqüentes, ficando para a conta de compensação, ou CVA, apenas as eventuais diferenças com relação ao valor previsto e o valor efetivamente realizado. 


\section{REGRAS E PROCEDIMENTOS DE COMERCIALIZAÇÃO}

\subsection{Considerações Iniciais}

As Regras de Comercialização são um conjunto de equações matemáticas e fundamentos conceituais, complementares e integrantes à Convenção de Comercialização de Energia Elétrica, instituída pela Resolução Normativa ANEEL $n^{\circ}$ 109/2004, que associadas aos seus respectivos Procedimentos de Comercialização, estabelecem as bases necessárias para a operação comercial da CCEE e estipulam o processo de contabilização e liquidação [5].

As Regras de Comercialização, referentes ao ano de 2011, possuem os seguintes módulos:

Contabilização

Módulo 1 - Preço de Liquidação das Diferenças

Módulo 2 - Determinação da Geração e Consumo de Energia

Módulo 3 - Contratos

Módulo 4 - Garantias Físicas

Módulo 5 - Excedente Financeiro

Módulo 6 - Encargos de Serviço do Sistema

Módulo 7 - Consolidação dos Resultados

Módulo 8 - Ajuste de Contabilização e Recontabilização

Também fazem parte das regras de Comercialização os módulos a seguir, porém não possuem numeração específica: (i) Contratação de Energia de Reserva; (ii) Definições e Interpretações; (iii) Governança; (iv) Liquidação; (v) Penalidades; (vi) Reajuste da Receita de Venda de CCEAR por Disponibilidade; e (vii) Repasse do Custo de Sobrecontratação de Energia Elétrica

Os Procedimentos de Comercialização (PdCs) são um conjunto de normas aprovadas pela ANEEL que definem condições, requisitos, eventos e prazos relativos à comercialização de energia elétrica no âmbito da CCEE e estão definidos conforme a estrutura da Cadeia de Valor da CCEE [5]. 
Os Procedimentos de Comercialização poderão ser atualizados em consonância com a legislação vigente, por iniciativa da ANEEL, por sugestão do Conselho de Administração da CCEE, pela Superintendência da CCEE, em caso de identificação de melhorias nos processos ou por solicitação de qualquer Agente da CCEE (www.ccee.org.br).

Os procedimentos de comercialização são relacionados a seguir:

AG - Registrar Agentes: (i) PdC AG.01 - Adesão à CCEE; PdC AG.02 Manutenção de Cadastro de Agentes da CCEE e Usuários do SCL; e (iii) PdC AG.03 - Desligamento da CCEE.

PE - Estabelecer Preços de Liquidação das Diferenças: PdC PE.01 - Estabelecer Preços de Liquidação de Diferenças (PLD).

CO - Registrar Contratos: (i) PdC CO.01 - Contratos Bilaterais; (ii) PdC CO.02 Sazonalização de Contrato Equivalente e Garantia Física; (iii) PdC CO.03 Modulação de Contrato Inicial; (iv) PdC CO.05 - Sazonalização de Contrato de Leilão de Venda; (v) PdC CO.06 - Modulação de Contrato de Leilão de Venda; (vi) PdC CO.07 - Revisão da Sazonalização de Garantia Física ; e (vii) PdC C0.11 Sazonalização de CCEAR.

ME - Registrar Dados de Medição: (i) PdC ME.01 - Registrar Dados de Medição no SCL; (ii) PdC ME.02 - Manutenção do Cadastro do Sistema Elétrico no SCL; (iii) PdC ME.04 - Mapeamento de Pontos de Medição no SCDE ; (iv) PdC ME.05 Manutenção do Cadastro de Medição do SCDE ; (v) PdC ME.06 - Coletar Dados de Medição no SCDE; (vi) PdC ME.07 - Apuração de Não-conformidades e Penalidades de Medição.

CZ - Processar Contabilização: (i) PdC CZ.01 - Cronograma Geral de Contabilização; (ii) PdC CZ.02 - Recontabilização e Ajustes na Contabilização e Liquidação; e (iii) PdC CZ.03 - Solicitação de Recontabilização.

DR - Divulgar Resultados: PdC DR.01 - Divulgação de Resultados.

LF - Efetuar Liquidação Financeira: (i) PdC LF.01 - Liquidação Financeira; (ii) PdC LF.03 - Aporte das Garantias Financeiras; e (iii) PdC LF.04 - Liquidação Financeira Relativa à Contratação de Energia de Reserva. 
AM - Acompanhar o Mercado: (i) PdC AM.01 - Entrada de Dados por Contingência ;

(ii) PdC AM.02 - Atendimento ao Agente da CCEE ; (iii) PdC AM.03 - Solução de Conflitos; (iv) PdC AM.04 - Administrar Votos e Contribuição Associativa; (v) PdC AM.10 - Aferição e Aplicação de Penalidades - Cobertura de Consumo, Lastro para Venda de Energia Elétrica e Potência e Indisponibilidade de Geração por Falta de Combustível ; (vi) PdC AM.11 - Divulgação de informações de Autoprodução e Produção; (vii) PdC AM.12 - Representação Contábil de Agentes ; (viii) PdC AM.13

- Registro, Tratamento e Apuração de Indisponibilidades de Usinas Hidráulicas não Despachadas Centralizadamente e Participantes do MRE; e (ix) PdC AM.14 Gestão do Pagamento de Penalidades.

AC - Administrar Contratos: (i) PdC AC.01 - Celebração de CCEAR de Leilão de Compra de Energia Elétrica Proveniente de Empreendimentos Existentes; (ii) PdC AC.02 - Mecanismo de Compensação de Sobras e Déficits (MCSD), Cessão e Redução de Montantes de Energia Elétrica de CCEARs; (iii) PdC AC.03 Mecanismo de Compensação de Sobras e Déficits (MCSD) Ex-Post; (iv) PdC AC.04 - Apuração e Liquidação dos Valores das Cessões do MCSD; (v) PdC AC.05 Tratamento da Energia do PROINFA na CCEE; e (vi) PdC AC.06 - Alterações de Dados Contratuais de CCEARs, CCGs, CERs e CONUERs e Celebração de Termos Aditivos e Termos de Cessão.

PdC Glossário de Termos da CCEE: PdC - Glossário de Termos da CCEE.

\subsection{Projeto Novo SCL}

Em razão da complexidade das regras de comercialização e para atender às demandas do mercado de energia elétrica, a CCEE iniciou em 2008 o Projeto do Novo Sistema de Contabilização e Liquidação que substituirá o antigo. Em breve síntese, seu objetivo é dar maior flexibilidade e dinamismo facilitando o atendimento às demandas futuras, por meio da simplificação das regras de comercialização e oferecendo maior clareza facilitando a disseminação do conhecimento. Referido Projeto tem a previsão para entrar em operação comercial ainda em 2012. 


\subsection{Proposta de criação do Comercializador Varejista}

O número de consumidores especiais ultrapassou o número de consumidores livres, tendo dobrado no período de um ano (2010 até 2011 - vide capítulo 3.11.2 Evolução dos Consumidores Especiais) e considerando a complexidade das regras de comercialização, a CCEE, em parceria com os agentes do setor elétrico, propôs a criação da figura do comercializador varejista que deveria ser implantado ainda no ano de 2012.

Em razão dos consumidores especiais não conhecerem profundamente as regras de comercialização e os procedimentos de comercialização de energia, são geradas dificuldades ao lidar com a legislação setorial e consequentemente a sua adesão na CCEE é dificultada. Dessa forma, a entrada do Comercializador Varejista proporcionará a alavancagem em maior proporção da entrada dos consumidores especiais no mercado livre, uma vez que criará uma ponte entre o gerador de energia incentivada e os consumidores especiais.

O Comercializador Varejista, será responsável por esses consumidores, tratando assim de todos os trâmites necessários perante a CCEE. Ato contínuo, a CCEE controlaria todas essas comercializadoras.

Para a criação do Comercializador Varejista ainda serão necessárias alterações nos documentos (i) Procedimentos de Comercialização de energia da CCEE (ii) Resolução n¹09/2004 que institui a Convenção de Comercialização de Energia Elétrica; (iii) Resolução $n^{\circ} \mathbf{2 6 5 / 1 9 9 8}$, que estabelece as condições para o exercício da atividade de comercialização de energia elétrica (iv) Resoluções $n^{\circ} \mathbf{s} 67 / 2004$ e 248/2007, que tratam, dentre outros assuntos, da adequação do sistema de faturamento e (v) Estatuto social da CCEE.

\subsection{Energia Assegurada}

Energia Assegurada é a energia que pode ser produzida com a garantia de $95 \%$, ou seja, somente em $5 \%$ do tempo a usina produzirá energia inferior à sua assegurada. 
A Energia Assegurada de uma determinada usina corresponde à fração ao que lhe for alocada da Energia Assegurada do sistema, em termos de comercialização de energia, corresponde à quantidade de energia que essa usina pode comprometer em contratos de venda.

Acrescente-se ainda que, a Portaria $n^{\circ}$ 303/2004 do MME estabelece a metodologia, as diretrizes para determinação a energia assegurada (garantia física) das usinas do Sistema Interligado Nacional (SIN).

\subsection{Mecanismo de Realocação de Energia - MRE}

A produção de energia elétrica de uma usina está diretamente relacionada ao despacho $^{11}$ centralizado realizado pelo ONS. Esse despacho considera as disponibilidades de cada uma das usinas em condições de operação no SIN. Essas usinas são despachadas com o objetivo de minimizar os custos operacionais e visando o menor custo marginal possível, tendo-se em vista as afluências na bacia hidrográficas, o armazenamento de água dos reservatórios, os preços ofertados pelas usinas térmicas e as restrições operacionais. Dessa forma, os agentes proprietários de usinas sujeitas ao despacho centralizado pelo ONS não tem controle sobre seu nível de geração, independentemente de seus compromissos de venda realizados com base nas garantias físicas [5].

Em razão das grandes dimensões territoriais do Brasil, existem diferenças hidrológicas significativas entre as regiões gerando períodos secos e úmidos não coincidentes. Uma região em período de seco armazena água e, por consequência, gera abaixo da média, enquanto que uma região, durante período de chuvoso, em geral produz acima da média. Além disso, para otimizar a geração, o ONS pode reduzir a produção de uma usina e aumentar a produção equivalente de outra. Dessa forma, para que isso seja realizado sem prejuízo dos compromissos de venda dos produtores de energia, foi criado o Mecanismo de Realocação de Energia (MRE).

\footnotetext{
${ }^{11}$ Despacho - Conjunto de instruções e de ações para controle da operação do sistema eletroenergético integrado brasileiro.
} 
O MRE é um instrumento de mitigação de risco hidrológico, que visa compartilhar, entre todos os geradores hidrelétricos, o risco da otimização hidrológica. É atribuída a cada gerador uma energia assegurada e a produção acima desses montantes é alocada àqueles geradores que estiverem produzindo menos que a sua energia assegurada.

Quando houver sobra de energia, ou seja, se a energia produzida por todos os geradores participantes do MRE for maior que a soma de seus níveis de energia assegurada, esse excedente, chamado de energia secundária do sistema, poderá ser vendido no mercado Spot.

Se a energia produzida por todos os geradores participantes do MRE for inferior à soma total das suas energias asseguradas, cada participante receberá sua energia ajustada, havendo a realocação de energia

Assim, o MRE é executado em duas situações: (a) Geração total do MRE maior ou igual ao total da Energia Assegurada modulada no sistema e (b) Geração total do MRE menor que o total da Energia Assegurada modulada no sistema.

\subsubsection{Geração total do MRE maior ou igual o total de Energia Assegurada modulada no sistema}

Conforme já explicado, o excedente de energia, referente à geração acima da soma total da Energia Assegurada do sistema é chamado Energia Secundária. Essa energia é distribuída entre todas as usinas participantes do MRE, de forma proporcional à contribuição da Energia Assegurada da usina no sistema.

As usinas que produziram energia acima de sua Energia Assegurada transferem seu excesso ao MRE e, posteriormente, recebem de volta sua parte referente à Energia Secundária (quando houver), enquanto que as usinas que produziram abaixo da sua Energia Assegurada recebem a Energia do MRE, até o limite de sua assegurada, recebendo ainda sua parte da Energia Secundária.

Em primeiro lugar, a energia excedente das usinas que geraram acima de sua Energia Assegurada é realocada para as usinas que geraram abaixo da sua Energia assegurada, dentro de cada submercado e, caso houver ainda um excedente, o 
mesmo será alocado a partir dos submercados superavitários para os deficitários, até completar os níveis da Energia Assegurada de todas as usinas. Dito isto, a quantidade total de energia remanescente após a realocação de toda a energia dentro de cada submercado, com transferência entre submercados para as usinas deficitárias, constitui a energia secundária do sistema, que será alocada proporcionalmente à Energia Assegurada do sistema.

A figura 5, a seguir, apresenta o processo de alocação de energia assegurada e energia secundária quando a geração total é superior à energia assegurada total do MRE:

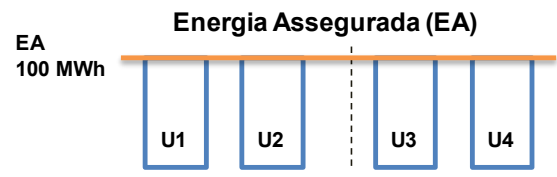

Submercado 1
Submercado 2

Energia Gerada Total > Energia Assegurada Total

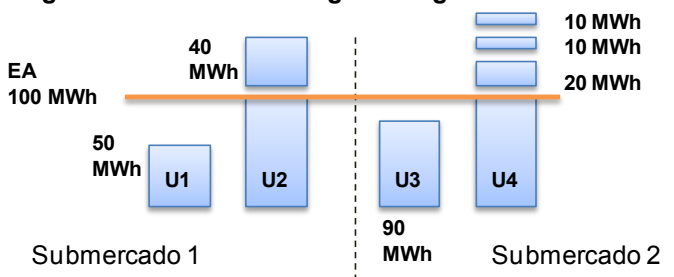

MWh Submercado 2

. Apesar de ser referente às usinas do Submercado 1, essas parcelas de Energia permanecem relacionadas ao Submercado 2 (Submercado da Usina que as gerou)
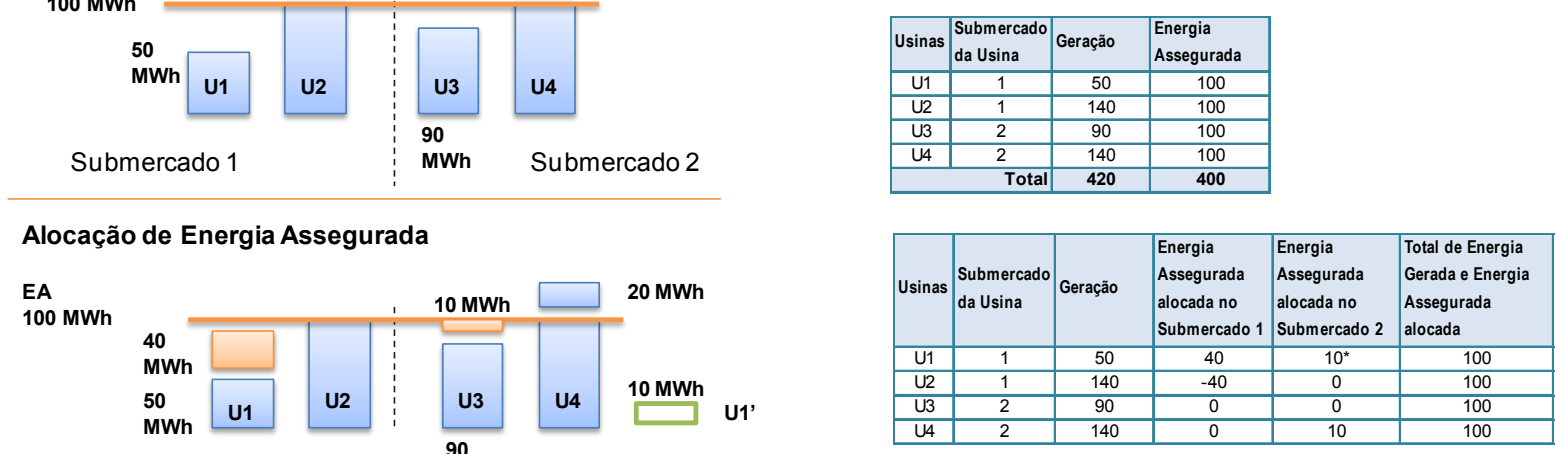

Submercado $1 \quad$ MWh Submercado 2
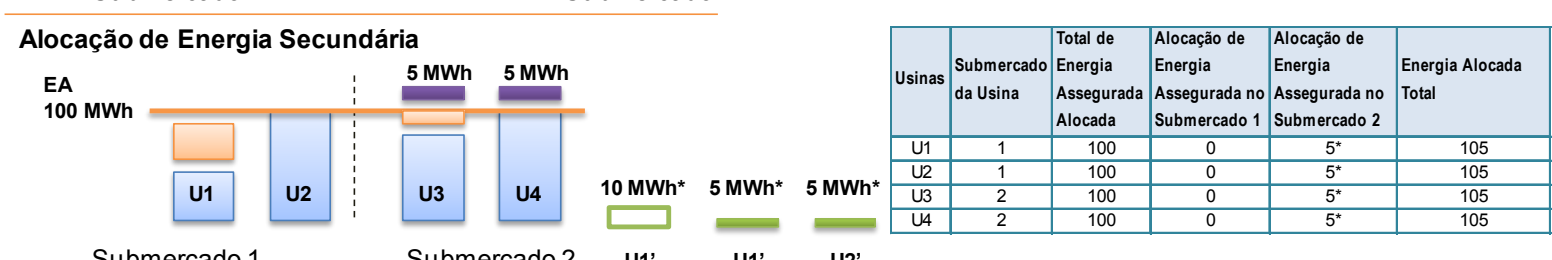

Submercado 1

Submercado 2

U1'

$\mathrm{U} \mathbf{1}^{\prime}$

U2'

Figura 5: Processo de alocação de energia assegurada e energia secundária quando a geração total é superior à energia assegurada total do MRE.

Fonte: CCEE - Câmara de Comercialização de Energia Elétrica. Visão Geral das Operações na CCEE. http://www.ccee.org.br [16]. 


\subsubsection{Geração total do MRE menor que o total da Energia Assegurada modulada no sistema}

Quando a geração total do MRE for menor que o total da Energia Assegurada modulada no sistema, obviamente não haverá energia secundária no sistema e os níveis de Energia Assegurada serão reduzidos por um fator de ajuste que é determinado pela razão entre a geração total do MRE e o nível total de Energia Assegurada do sistema em cada patamar, sendo que o valor resultante para cada usina é denominado Energia Assegurada Ajustada.

As usinas que produzem acima do valor ajustado doam o excesso para o MRE, enquanto as usinas que produzem abaixo recebem do MRE até o limite ajustado. Em outras palavras, na ocorrência de situações como essa, o MRE não é capaz de cobrir o risco do Agente de Geração ter que comprar energia no mercado de curto prazo para atender seus contratos, ao Preço da Liquidação das Diferenças, o qual pode ser mais elevado que os preços estabelecidos em tais contratos [16].

A alocação de energia das usinas com excedente de Energia Assegurada para aquelas com déficit de Energia Asegurada é feita prioritariamente entre usinas dentro de cada submercado. $O$ excedente remanescente é alocado então a partir dos submercados superavitários para os deficitários, até o preenchimento dos níveis de Energia Assegurada de todas as usinas [16].

Na figura 6, a seguir, é apresentado o processo de alocação e redução de energia assegurada quando a geração total é inferior à energia assegurada total do MRE:

\subsubsection{Tarifa de Energia de Otimização - TEO}

O MRE compensa os geradores que produzem energia ao SIN acima de sua energia assegurada. Assim esses geradores são ressarcidos por meio do pagamento de seus custos variáveis de operação, conforme regulamentado pela ANEEL. 


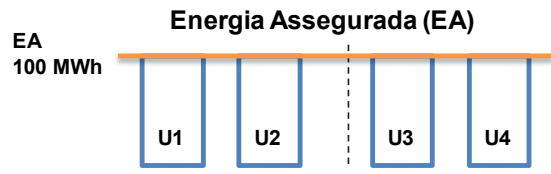

Submercado 1
Submercado 2

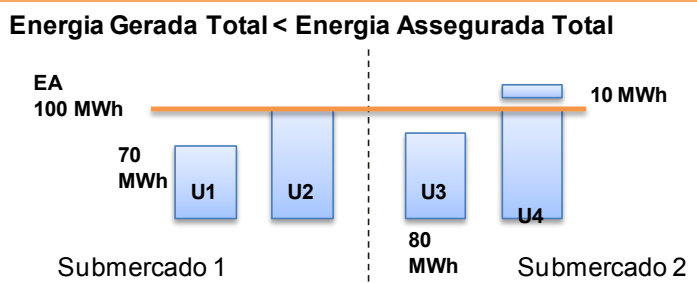

*Apesar de ser referente às usinas do Submercado 1, essas parcelas de Energia Secundária permanecem relacionadas ao Submercado 2 (Submercado da Usina que as gerou)

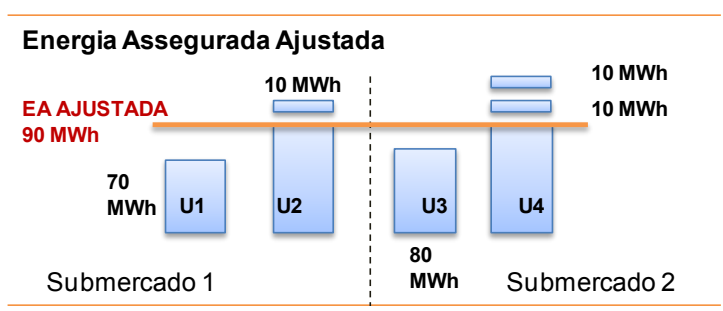

Alocação de Energia Secundária

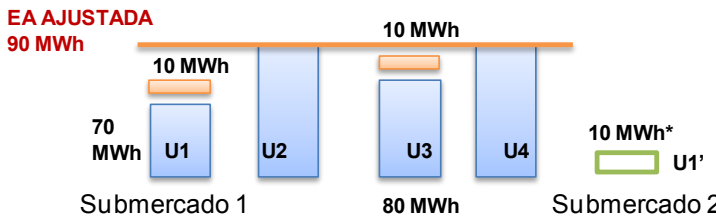

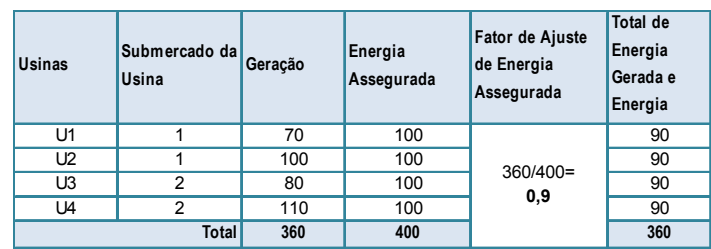

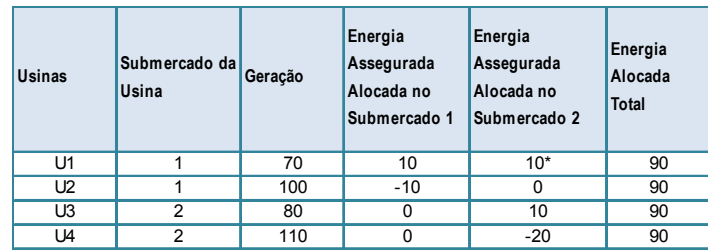

Submercado 1

$80 \mathrm{MWh}$

Submercado 2

Figura 6: Alocação e redução de energia assegurada quando a geração total é inferior à energia assegurada total do MRE.

Fonte: CCEE - Câmara de Comercialização de Energia Elétrica. Visão Geral das Operações na CCEE. http://www.ccee.org.br [16].

Nesse contexto, o Decreto $n^{\circ} \mathbf{2 . 6 5 5 / 1 9 9 8}$ regulamenta o Mercado Atacadista de Energia Elétrica, define as regras de organização do Operador Nacional do Sistema, conforme a seguir:

"Art. 21. A cada usina hidrelétrica corresponderá um montante de energia assegurada, mediante mecanismo de compensação da energia efetivamente gerada. (Redação dada pelo Decreto $n^{\circ} 3.653$, de, 7 de novembro de 2000)"

Art 22. As transferências de energia entre as usinas participantes do MRE, visando a alocação de que trata o artigo anterior, estarão sujeitas à aplicação de encargo, baseado em tarifa de otimização estabelecida pela ANEEL, destinado à cobertura dos custos incrementais incorridos na operação e manutenção das usinas hidrelétricas e pagamento da compensação financeira pelo uso dos recursos hídricos.

Portanto, a TEO deve cobrir os custos incrementais de operação e manutenção das usinas hidrelétricas e o pagamento adicional da compensação financeira pelo uso dos recursos hídricos. 
Vale ressaltar ainda, que em acordo com os Art. 23 e 24 do Decreto $n^{\circ}$ 2.655/1998:

Art 23. O MRE incluirá regras para a alocação, entre os seus membros, da energia efetivamente gerada, as quais levarão em conta as perdas de transmissão e deverão se basear em um ou mais dos seguintes parâmetros:

II - energia assegurada da usina;

II - capacidade instalada da usina;

III - geração efetiva de energia de cada usina.

Art 24. Os riscos de indisponibilidade das usinas de geração hidrelétrica, de natureza não hidrológica, serão assumidos individualmente pelas usinas participantes, não sendo, portanto, cobertos pelo MRE.

A Resolução Homologatória $n^{\circ}$ 406/2006, estabelece o valor da Tarifa de Otimização (TEO) em R\$ 7,47/MWh, com vigência a partir de $1^{\circ}$ de janeiro de 2007 , para valorar a energia transferida entre as usinas participantes do Mecanismo de Realocação de Energia (MRE), no âmbito da Câmara de Comercialização de Energia Elétrica (CCEE).

\subsection{Mecanismo de Redução de Assegurada - MRA}

A partir de julho de 2004, foi instituído o Mecanismo de Redução de Energia Assegurada (MRA), aplicado mensalmente às usinas participantes do MRE que não cumpram com os requisitos de disponibilidade definidos, os quais estabelecem valores de referência para interrupções forçadas e programadas das usinas. O MRA reduz a Energia Assegurada da usina sempre que esses valores de referência são superados.

O ONS acompanha o desempenho das usinas e informa à CCEE os valores médios mensais verificados de interrupções forçadas e programadas, relativos aos 60 meses imediatamente anteriores ${ }^{12}$. Nessa situação, a Energia Assegurada será reduzida somente para fins de participação do MRE, não impactando na apuração de garantia física da usina.

\footnotetext{
${ }^{12}$ Para a obtenção das médias, caso não se disponha dos valores mensais apurados que totalizem os 60 meses, os valores faltantes devem ser complementados utilizando-se os valores de referência, considerados no cálculo da respectiva energia assegurada. Na apuração das taxas equivalentes de Indisponibilidades Forçadas (TEIFa) e de Indisponibilidade Programa (TEIP), o ONS deverá desconsiderar a indisponibilidade, conforme critérios estbelecidos na Resolução Normativa ANEEL $n^{\circ} 160 / 2005$, desde que justificados pelo agente de geração.
} 


\subsection{Geração Distribuída}

O Decreto $n^{\circ} 5.163 / 2004$ estabelece em seu artigo $n^{\circ} 14$, que é considerado Geração Distribuída (GD) a produção de energia elétrica proveniente de empreendimentos de agentes concessionários, permissionários ou autorizados, incluindo aqueles tratados pelo artigo $n^{\circ} 8$ da Lei $n^{\circ}$ 9.074/1995, conectados diretamente no sistema elétrico de distribuição do comprador, exceto aquela proveniente de empreendimento: (i) hidrelétrico com capacidade instalada superior a $30 \mathrm{MW}$; e (ii) termelétrico, inclusive de cogeração, com eficiência energética inferior a setenta e cinco por cento, conforme regulação da ANEEL, a ser estabelecida até dezembro de 2004.

Em outras palavras, entende-se como Geração Distribuída a geração conectada diretamente ao centro de carga através das redes de distribuição, sem necessidade de utilizar ativos de transmissão.

Assim, a Geração Distribuída pode ser considerada como atenuante para a distribuidora de energia elétrica, uma vez que não ficaria dependente totalmente da contratação proveniente da realização dos leilões de energia pela CCEE.

A Lei $n^{\circ} \mathbf{1 0 . 8 4 8 / 2 0 0 4}$, artigo $n^{\circ} 2$ e $\S 8$, estabelece que no atendimento à obrigação de contratação da totalidade do mercado dos agentes de distribuição, deverá ser considerada a energia elétrica proveniente de geração distribuída, observados os limites de contratação e de repasse às tarifas, baseados no valor de referência do mercado regulado e nas respectivas condições técnicas.

Ainda de acordo com o artigo $n^{\circ} 15$ do Decreto $n^{\circ} 5163 / 2004$, a contratação de energia elétrica proveniente de empreendimentos de Geração Distribuída será precedida de chamada pública promovida diretamente pelo agente de distribuição, de forma a garantir publicidade, transparência e igualdade de acesso aos interessados. Outro ponto importante é que o montante da energia elétrica contratada proveniente de empreendimentos de Geração Distribuída não poderá exceder a (10\%) dez por cento da carga do Agente de Distribuição. 
O artigo $n^{\circ} 15$, do Decreto $n^{\circ}$ 5.163/2004 também estabelece que o contrato de compra e venda de energia elétrica proveniente de empreendimentos de Geração Distribuída (GD) deverá prever, em caso de atraso do início da operação comercial ou de indisponibilidade da unidade geradora, a aquisição de energia no mercado de curto prazo pelo agente de distribuição.

Acrescente-se ainda que o lastro para venda de energia elétrica proveniente de empreendimentos de Geração Distribuída (GD) será definido conforme o estabelecido nos $\S \S 1^{\circ}$ e $2^{\circ}$ do artigo $2^{\circ}$ do Decreto $n^{\circ} 5.163 / 2004$, conforme transcrito a seguir:

"§ 10 O lastro para a venda de que trata o inciso I do caput será constituído pela garantia física proporcionada por empreendimento de geração próprio ou de terceiros, neste caso, mediante contratos de compra de energia ou de potência.

§ 20 A garantia física de energia e potência de um empreendimento de geração, a ser definida pelo Ministério de Minas e Energia e constante do contrato de concessão ou ato de autorização, corresponderá às quantidades máximas de energia e potência elétricas associadas ao empreendimento, incluindo importação, que poderão ser utilizadas para comprovação de atendimento de carga ou comercialização por meio de contratos."

Com relação aos incentivos à energia, cabe mencionar que a energia proveniente da Geração Distribuída possui desconto de $50 \%$ e $100 \%{ }^{13}$, nas Tarifas do Uso do Sistema de Transmissão (TUST) e nas Tarifas do Sistema de Distribuição (TUSD).

Adicionalmente, é importante salientar que a Geração Distribuída pode ser considerada como fonte complementar à geração hidrelétrica, quando se tratar de geração termelétrica a biomassa, uma vez que o período da produção da cana ocorre entre os meses de maio a outubro, ou seja, justamente no período seco da geração hidrelétrica.

\footnotetext{
${ }^{13}$ Não inferior a $50 \%$, podendo atingir $100 \%$.
} 


\section{ENERGIA INCENTIVADA}

\subsection{Aspectos Conceituais e de Comercialização}

O crescimento do mercado livre por meio da comercialização da energia incentivada é um importante fator da inserção das fontes alternativas renováveis.

Destacam-se nesse ambiente a energia proveniente de PCH's, empreendimentos eólicos e as térmicas a biomassa. A comercialização de energia incentivada possui papel importante na expansão da oferta de eletricidade no Brasil.

\subsubsection{Considerações Gerais}

No período de 08 a 23 de março de 2007, foi realizada a Audiência Pública $n^{\circ}$ 05/2007 para coleta de subsídios e informações para o aperfeiçoamento das Regras de Comercialização, aplicáveis a fontes incentivadas e consumidores especiais. Ato contínuo, a Resolução Normativa $n^{\circ}$ 286/2007, aprovou as Regras de Comercialização de Energia Elétrica aplicáveis a fontes incentivadas e consumidores especiais, de que trata a Resolução Normativa $n^{\circ}$ 247/2006.

A Resolução Normativa $n^{\circ}$ 247/2006 estabeleceu as condições para comercialização de energia elétrica, oriunda de empreendimentos de geração que utilizem fontes primárias incentivadas, com unidade ou conjunto de unidades consumidoras cuja carga seja maior ou igual a $500 \mathrm{~kW}$. A regulamentação acima citada foi objeto da Audiência Pública $n^{\circ}$ 033/2005, realizada no dia 11 de janeiro de 2006.

Referida resolução, em seu Art. $n^{\circ} 7$, também estabelece que o Agente Gerador Incentivado e o Consumidor Especial devem participar da CCEE, podendo ser representados, para efeitos de contabilização e liquidação, pelo comercializador autorizado pela ANEEL.

Importante acrescentar ainda que o Decreto $n^{\circ}$ 5.177/2004 (Art. 4 e Inciso VI) em acordo com $\circ$ Art. $n^{\circ} 6$ e $\S 5$ da Lei $n^{\circ}$ 9427/1996, obriga a participação dos 
consumidores livres e especiais como agentes da Câmara de Comercialização de Energia Elétrica (CCEE).

\subsection{Consumidor Especial}

\subsubsection{Definições e Regulamentação}

A título histórico, é importante apresentar que, inicialmente a Lei $n^{\circ} 9.648 / 1998$ e $\mathrm{n}^{\circ}$ 4, altera a Lei $n^{\circ} 9.427 / 1998$ e artigo $n^{\circ} 26$. Aqui é criada a figura do consumidor especial (carga $\geq 500 \mathrm{~kW})$.

"Art. 26. Depende de autorização da ANEEL:

I - o aproveitamento de potencial hidráulico de potência superior a $1.000 \mathrm{~kW}$ e igual ou inferior a $30.000 \mathrm{~kW}$, destinado a produção independente ou autoprodução, mantidas as características de pequena central hidrelétrica;

§ 10 Para cada aproveitamento de que trata o inciso I, a ANEEL estipulará percentual de redução não inferior a 50\% (cinqüenta por cento), a ser aplicado aos valores das tarifas de uso dos sistemas elétricos de transmissão e distribuição, de forma a garantir competitividade à energia ofertada pelo empreendimento.

$\S 50$ Os aproveitamentos referidos no inciso I poderão comercializar energia elétrica com consumidores cuja carga seja maior ou igual a $500 \mathrm{~kW}$, independentemente dos prazos de carência constantes do art. 15 da Lei no 9.074, de 1995".

Em 2002, a Lei $\boldsymbol{n}^{\mathbf{0}} \mathbf{1 0 . 4 3 8}$, inclui a possibilidade de comercialização de energia eólica, solar e biomassa.

Art. $26 \S 50$ O aproveitamento referido no inciso I e aqueles a partir de fontes eólica, biomassa ou solar poderão comercializar energia elétrica com consumidor ou conjunto de consumidores reunidos por comunhão de interesses de fato ou direito, cuja carga seja maior ou igual a $500 \mathrm{~kW}$, independentemente dos prazos de carência constantes do art. 15 da Lei no 9.074, de 7 de julho de 1995, observada a regulamentação da Aneel.

Posteriormente, a Lei $n^{\circ} \mathbf{1 0 . 7 6 2 / 2 0 0 3}$ altera o artigo $n^{\circ} 26$ da Lei $n^{\circ} 9.427 / 1998$, que conforme dito acima, já havia sido alterado pela Lei $n^{\circ}$ 9.648/1998.

Art. 26 - § 10 Para o aproveitamento referido no inciso I do caput, os empreendimentos hidroelétricos com potência igual ou inferior a $1.000 \mathrm{~kW}$ e aqueles com base em fontes solar, eólica, biomassa e cogeração qualificada, conforme regulamentação da ANEEL, cuja potência instalada seja menor ou igual a $30.000 \mathrm{~kW}$, a ANEEL estipulará percentual de redução não inferior a cinqüenta por cento a ser aplicado às tarifas de uso dos sistemas elétricos de transmissão e de distribuição, incidindo na produção e no consumo da energia comercializada pelos aproveitamentos. 
Finalmente, o Artigo $n^{\circ} 1$ da Resolução Normativa $n^{\circ}$ 247/2006 estabelece as condições para a comercialização de energia elétrica, no âmbito do SIN, do consumidor especial com geração oriunda de:

1) Aproveitamentos de Potencial Hidráulico PCH's (> 1MW e $\leq 30 \mathrm{MW}$ ) - Produção Independente ou Autoprodução;

2) Empreendimentos Hidrelétricos com Potência Instalada $\leq 1 \mathrm{MW}$; e

3) Empreendimentos cuja fonte primária de geração seja a biomassa, energia eólica ou solar - Potência Injetada nos sistemas de transmissão ou distribuição $\leq 30$ MW.

Ainda a Resolução Normativa $n^{\circ}$ 247/2006, definiu o Consumidor Especial (Agentes Compradores de Energia Elétrica): consumidor responsável por unidade consumidora ou conjunto de unidades consumidoras do Grupo "A", integrante(s) do mesmo submercado no SIN, reunidas por comunhão de interesses de fato ou de direito, cuja carga seja maior ou igual a $500 \mathrm{~kW}$.

De acordo com a referida resolução o Consumidor Especial deverá garantir o atendimento a $100 \%$ (cem por cento) de sua carga, em termos de energia e potência, por intermédio de geração própria, de contrato de fornecimento com agente de distribuição ou de CCEI.

Importante acrescentar que a distribuidora ou transmissora de energia, em cujo sistema a unidade consumidora esteja conectada, deverá celebrar com os consumidores, ou conjunto de consumidores, os contratos: (i) Contrato de Conexão ao Sistema de Distribuição (CCD) ou Contrato de Conexão do Sistema de Transmissão (CCT); e (ii) Contrato de Uso do Sistema de Distribuição (CUSD) ou Contrato de Uso do Sistema de Transmissão (CUST).

Ainda, o Consumidor Especial que optou por adquirir parte ou a totalidade do seu consumo de energia por meio de comercialização, em acordo com a Resolução Normativa $n^{\circ} \mathbf{2 4 7 / 2 0 0 6}$, poderá voltar a ser atendido plenamente pela distribuidora de energia, sob a prevalência de tarifas e condições reguladas. 
Assim ao optar pelo retorno ao mercado regulado, deverá formalizar à distribuidora com antecedência de 180 (cento e oitenta) dias ${ }^{14}$, em relação à data do início de fornecimento, cujo prazo poderá ser reduzido a critério da distribuidora. Ato contínuo, será de total responsabilidade desse consumidor eventuais repercussões financeiras em razão da desistência do seu retorno ao ambiente regulado.

\subsubsection{Evolução dos Consumidores Especiais}

De acordo com o gráfico 1, a seguir, destaca-se que ao longo do ano de 2010 e final de 2011, o número de consumidores especiais cresceu de forma considerável superando o número de consumidores livres, ou seja, em relação ao período destacado o número total de consumidores especiais cresceu $116,6 \%$, enquanto que o número de consumidores livres cresceu apenas $11,2 \%$.

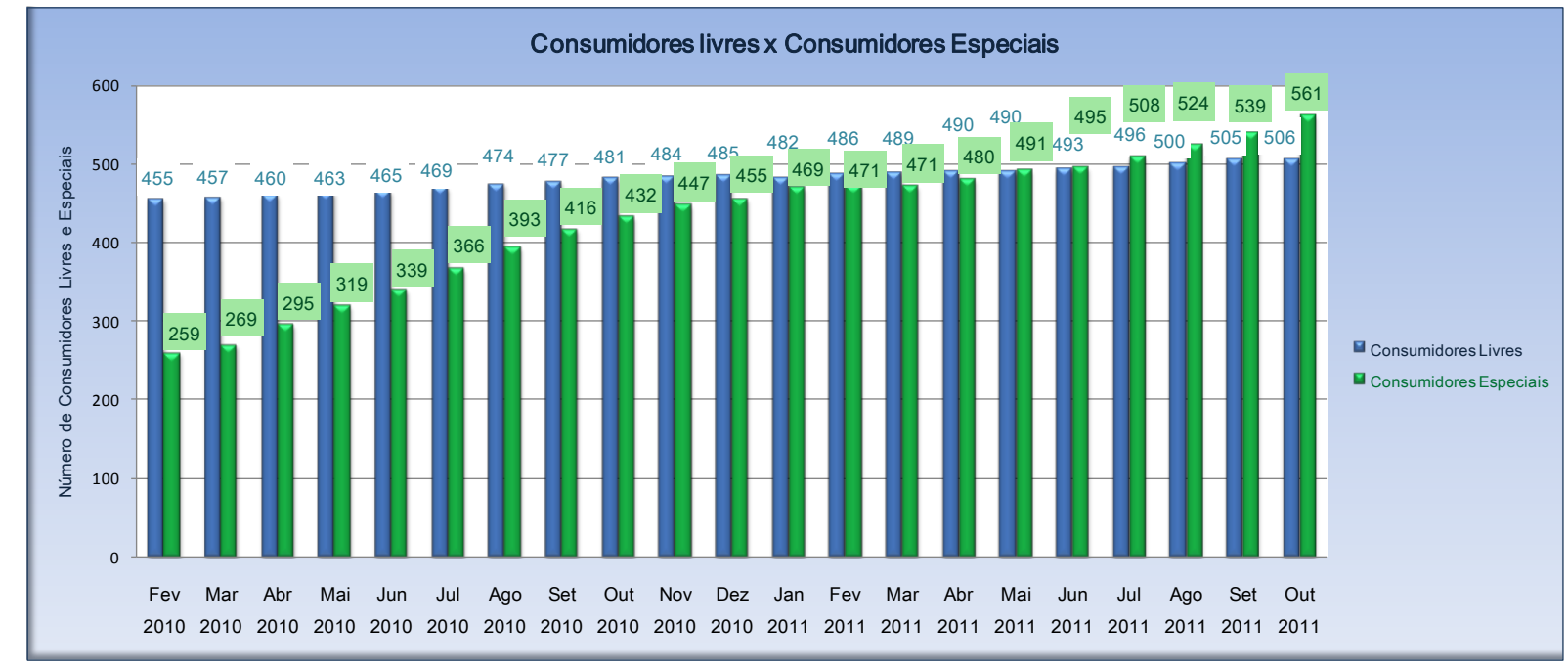

Gráfico 1: Gráfico do Número de Consumidores Livres x Número de Consumidores Especiais Fonte: Elaboração própria a partir de informações pela CCEE (www.ccee.org.br).

Apesar de ter sido considerada, para este trabalho, a data de corte de atualização das informações até junho de 2012, vale a pena registrar a publicação da MP 579 , de 11 de setembro de 2012, que dispõe sobre a redução dos encargos do setor elétrico e também estabelece prazo de retorno de cinco anos ao mercado cativo para consumidores especiais. Mesmo não sendo realizada uma análise a respeito da referida Medida Provisória neste trabalho, pode-se adiantar aqui que tais

${ }_{14}$ Alterado pela MP 579/2012, que estabelece prazo de retorno ao mercado cativo, igual ao Consumidor Livre, ou seja, de 5 anos. 
alterações podem afetar o mercado de consumo de energia renovável. Atualmente já existe uma movimentação dos consumidores de energia especial no sentido de tentar retornar ao mercado cativo.

\subsection{Outros Consumidores de Energia Elétrica}

Faz-se importante acrescentar nesse trabalho, além da definição de consumidores especiais, todos os tipos de consumidores definidos em regulação, conforme a seguir.

Ressalte-se que qualquer consumidor atuante do mercado livre pode realizar a compra de energia incentivada, porém somente os consumidores caracterizados como incentivados na CCEE, receberão os incentivos previstos para os agentes incentivados, valendo também para qualquer gerador ou comercializador que atue no mercado livre.

\section{Consumidor Livre}

O Consumidor Livre é aquele que pode exercer a livre opção de compra de energia, negociando livremente os preços da energia.

A Lei $\boldsymbol{n}^{\circ} \mathbf{9 . 0 7 4 / 1 9 9 5}$ criou a figura do Consumidor Livre (Artigos 15 e 16):

"Seção III - Das Opções de Compra de Energia Elétrica por parte dos Consumidores.

Art. 15. Respeitados os contratos de fornecimento vigentes, a prorrogação das atuais e as novas concessões serão feitas sem exclusividade de fornecimento de energia elétrica a consumidores com carga igual ou maior que $10.000 \mathrm{~kW}$, atendidos em tensão igual ou superior a $69 \mathrm{kV}$, que podem optar por contratar seu fornecimento, no todo ou em parte, com produtor independente de energia elétrica.

§ 10 Decorridos três anos da publicação desta Lei, os consumidores referidos neste artigo poderão estender sua opção de compra a qualquer concessionário, permissionário ou autorizado de energia elétrica do sistema interligado. (Redação dada pela Lei n 9.648 , de 1998)

§ 20 Decorridos cinco anos da publicação desta Lei, os consumidores com carga igual ou superior a $3.000 \mathrm{~kW}$, atendidos em tensão igual ou superior a $69 \mathrm{kV}$, poderão optar pela compra de energia elétrica a qualquer concessionário, permissionário ou autorizado de energia elétrica do mesmo sistema interligado.

Art. 16. É de livre escolha dos novos consumidores, cuja carga seja igual ou maior que $3.000 \mathrm{~kW}$, atendido, sem qualquer tensão, o fornecedor com quem contratará sua compra de energia elétrica." 
A Resolução Normativa $n^{\circ}$ 376/2009, estabelece as condições de contratação de energia elétrica, por Consumidor Livre no âmbito do SIN e revoga a Resolução ANEEL 264/1998 que trata o mesmo assunto.

"Art.1 e Parágrafo Único - Para fins desta Resolução, Consumidor Livre é o agente da Câmara de Comercialização de Energia Elétrica - CCEE, da categoria de comercialização, responsável por unidade consumidora enquadrada nas condições estabelecidas nos arts. 15 e/ou 16 da Lei n ${ }^{\circ} 9.074$, de 7 de julho de 1995."

O Decreto $n^{\circ}$ 5.163/2004 define o consumidor livre:

"Art. 1 - §2 - $\boldsymbol{X}$ - consumidor livre é aquele que, atendido em qualquer tensão, tenha exercido a opção de compra de energia elétrica, conforme as condições previstas nos arts. 15 e 16 da Lei n $n^{\circ}$ 9.074, de 7 de julho de 1995;"

\section{Consumidor Potencialmente Livre}

O Consumidor Potencialmente Livre (CPL) é aquele que apesar de apresentar as condições de consumidor livre (opção de compra de energia de qualquer fornecedor), é atendido no mercado cativo. (Decreto $n^{\circ} 5.163 / 2004$, Art. 1 , $\S 2$ e Inciso XI)

O Consumidor Potencialmente Livre que optar por comprar energia de outro fornecedor deve informar a distribuidora até quinze dias antes das declarações de suas necessidades de energia para o leilão "A-1".

A aquisição de energia de outro fornecedor poderá ser iniciada somente a partir de janeiro do ano subseqüente ao da declaração. O Consumidor Potencialmente Livre poderá contratar junto a outro fornecedor uma parte ou a totalidade de sua carga. Os contratos que tenham prazos de denúncia diferentes terão suas condições respeitadas.

É ainda estabelecido que se um consumidor livre optar por voltar a adquirir energia da distribuidora local deverá formalizar esta decisão com cinco anos de antecedência do início do fornecimento. A distribuidora poderá atendê-lo em prazo inferior, a seu exclusivo critério. 


\section{Consumidor Parcialmente Livre}

O consumidor Parcialmente Livre é aquele que exerce a opção de contratar parte das necessidades de energia e potência das unidades consumidoras de sua responsabilidade com a distribuidora local, nas mesmas condições reguladas aplicáveis a consumidores cativos, incluindo tarifas e prazos (Resolução Normativa $n^{\circ} 376 / 2009$, Art. $\left.n^{\circ} 15\right)$

\subsection{Gerador de Energia Incentivada}

A Resolução Normativa $n^{\circ}$ 247/2006, definiu O Agente Gerador Incentivado (Agentes Vendedores de Energia Incentivada): titular de concessão, permissão ou autorização do Poder Concedente para gerar energia elétrica.

Para complementação de lastro de venda, o Agente Gerador Incentivado deverá registrar somente contratos de fontes definidas conforme Art. $n^{\circ} 01$, da Resolução Normativa $n^{\circ} 247 / 2006$.

Além disso, para fins de complementação de geração, o Agente Gerador Incentivado poderá registrar contratos de aquisição de outras fontes de geração, de até 49\% (quarenta e nove por cento) de sua garantia física.

Assim, a CCEE verificará mensalmente, para cada agente vendedor de Energia Incentivada, o atendimento ao limite de $49 \%$ da Garantia Física, apurada das usinas cadastradas em seu nome, para registro de contratos de compra de energia oriunda de fontes não especiais, e no caso de ultrapassagem desse limite será atribuído desconto zero para as usinas de propriedade desse agente no mês do cálculo.

Para melhor entendimento, a figura 7, a seguir, representa como é realizada a verificação de atendimento ao limite de $49 \%$ da Garantia Física, para o registro de contratos de compra de energia de fontes não especiais, ou seja, fontes convencionais de energia.

Além disso, a CCEE informará a referida ocorrência à ANEEL e ao agente de distribuição ou transmissão ao qual cada usina do agente vendedor de energia incentivada estiver conectada. 
Importante acrescentar, no caso de mais de 3 períodos de comercialização em que a energia elétrica injetada, aferida no ponto de medição de faturamento, pelo empreendimento de geração que utiliza fonte incentivada de energia, nos sistemas de transmissão ou distribuição, for superior a $30 \mathrm{MW}$ médios, contabilizados no período de um mês, será aplicada, a título de penalidade, a perda total do desconto associado ao Agente Gerador Incentivado.

\begin{tabular}{|c|} 
Vendedor de Energia Incentivada \\
\begin{tabular}{|c|c|}
\hline $\begin{array}{c}\text { Contratos de Compra de } \\
\text { Energia Incentivada } \\
\text { (MWh) }\end{array}$ & $\begin{array}{c}\text { Contratos de Compra de } \\
\text { Energia Convencional } \\
\text { (MWh) }\end{array}$ \\
\hline 300 & 600 \\
\hline 200 & 500 \\
\hline 100 & 400 \\
\hline Total = 600MWh & Total = 1500 MWh \\
\hline
\end{tabular}
\end{tabular}

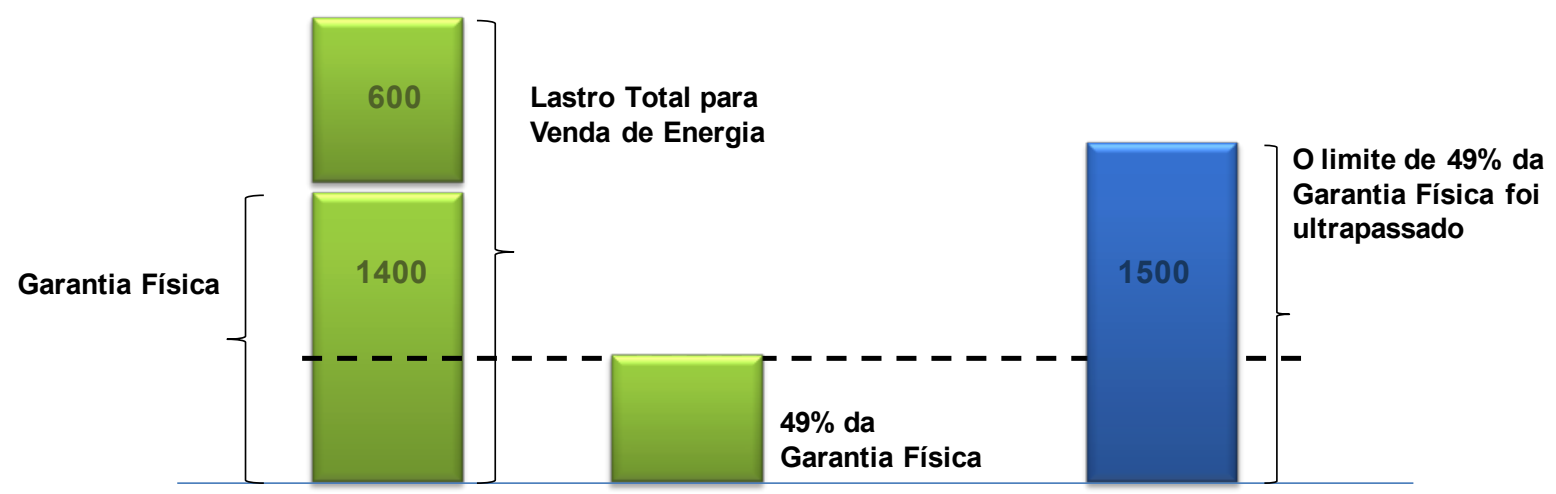

A verificação do limite de $49 \%$ da Garantia Física é realizada observando um período de 12 meses

Todas as usinas de fontes incentivadas do gerador que ultrapassar o limite de $49 \%$ serão afetadas em seu desconto.

Figura 7: Representação da verificação de atendimento ao limite de $49 \%$ da Garantia Física, para o registro de contratos de compra de energia de fontes não especiais.

Fonte: Elaboração própria utilizando os conceitos do Treinamento de Comercialização de Energia incentivada [6].

A Resolução Normativa $n^{\circ} 247 / 2006$, no $\$ 1^{\circ}$ do Art. $3^{\circ}$, estabelece ainda que, no caso de ultrapassagem maior que $5 \%$ (cinco por cento) do montante de uso do sistema de transmissão ou distribuição contratado por ponto de conexão, será aplicada, a título de penalidade uma tarifa de ultrapassagem sem o desconto previsto, de valor igual a três vezes a tarifa de uso estabelecida para cada período.

É estabelecido ainda nesta resolução que, para fins de redução não inferior a 50\% (cinqüenta por cento) a ser aplicada às TUST's e TUSD's, a redução final deve ser 
calculada proporcionalmente aos sub-montantes obtidos a partir dos MW médios provenientes de cada fonte individualmente, e para cada período de consumo.

\subsection{Sistema de Medição para Faturamento (SMF)}

A Convenção de Comercialização, homologada pela Resolução ANEEL $\boldsymbol{n}^{\circ}$ 109/2004 determina que a CCEE é responsável pela especificação, orientação e determinação dos aspectos referentes à adequação do Sistema de Medição de Faturamento (SMF), e pela implantação, operação e manutenção do SCDE Sistema de Coleta de Dados de Energia, de modo a viabilizar a coleta dos dados de energia elétrica para uso no Sistema de Contabilização e Liquidação - SCL, de forma a garantir a exatidão das grandezas apuradas, bem como o cumprimento dos prazos exigidos.

O Sistema de Medição para faturamento é necessário para a medição das grandezas elétricas utilizadas na contabilização e faturamento de energia elétrica comercializada na CCEE.

Conforme já dito, a CCEE adiministra o SCDE (Sistema de Coleta de Dados de Energia), que coleta e trata os dados de geração e consumo de todos os pontos de medição dos Agentes que participam da CCEE. Tais dados de medição são coletados vias telemedição (internet) e utilizados na contabilização e liquidação da CCEE conforme as Regras e Procedimentos de Comercialização de Energia.

Todos os Agentes da CCEE, para se interligarem ao SCDE, devem adequar seu sistema de medição de acordo com os requisitos técnicos constantes no Anexo 1Especificação técnica das medições para faturamento do submódulo 12.2 Instalação de Medição para Faturamento do Módulo 12 dos Procedimentos de Rede do ONS.

Após a adequação do sistema de medição ao SCDE, os Agentes devem cadastrar os seus pontos de medição físicos ${ }^{15}$ no SCDE para que seja realizada a coleta de

\footnotetext{
${ }^{15}$ Ponto de Medição Físico é o local de instalação de instrumentos para medir grandezas elétricas utilizadas na contabilição e liquidação da energia elétrica comercializada na CCEE.
} 
dados diários de geração. Cabe ressaltar que a CCEE analisa a estabilidade de coleta e compatibilidade dos dados coletados pelo SCDE.

\subsection{Modelagem dos Agentes Incentivados}

Para permitir a correta contabilização da energia na CCEE, foi necessária a representação do diagrama unifilar da rede elétrica (física) dos geradores, comercializadores e geradores em uma linguagem aceitável pelo programa computacional Sinercom, que processa as contabilizações do Mercado. Para tanto, são criados ativos de medição (usinas, unidades geradoras e cargas), interligados através de conexões entre nós monitores e receptores. Os Procedimentos para a modelagem de ativos no Sinercom estão definidos no PdC ME-02 - Manutenção do Cadastro do Sistema Elétrico.

Com a entrada da comercialização de energia incentivada na CCEE (operacionalização), foi necessária também a modelagem de ativos na CCEE nos perfis de consumidor especial, agente de geração incentivada e os agentes comercializadores interessados em intermediar a comercialização da energia proveniente desses agentes geradores de energia incentivada com os consumidores especiais.

Dessa forma, foi criado, por meio de modelagem, um agente vinculado cuja classe é gerador ou comercializador Incentivado ou consumidor especial.

Assim, o gerador de energia que optar por atuar na comercialização de energia incentivada, se representar ativos de geração de energia incentivada de $50 \%$ de desconto na TUSD/TUST, deve modelar na CCEE o perfil de Agente Gerador Vinculado de $50 \%$ de Desconto e o mesmo vale para o Agente que representar ativos de geração incentivada com $100 \%$ de desconto na TUSD/TUST, porém o cadastro deverá ser modelado como Agente Gerador Vinculado de $100 \%$ de desconto na TUSD/TUST.

Já o agente comercializador de energia incentivada deve modelar na CCEE o Agente Comercializador Vinculado de $50 \%$ de desconto na TUSD/TUST ou Agente 
Comercializador Vinculado de $100 \%$ de desconto na TUSD/TUST, conforme o seu caso específico.

Para entender melhor o significado de agente vinculado, dentro do conceito da modelagem, que representa a comercialização de energia incentivada na CCEE, são apresentadas as figuras a seguir:

As figuras 8 e 9, a seguir, ilustram a configuração do ambiente de comercialização de energia Convencional e a configuração do ambiente de comercialização de energia incentivada, para o caso dos Geradores e Comercializadores. Para os geradores convencionais que possuíam geração incentivada, foram criados agentes vinculados Geradores ou Comercializadores Incentivados e para os consumidores convencionais que possuíam cargas especiais, foram criados os agentes vinculados, chamados de Consumidores Especiais.

As setas verdes demonstram as adequações que foram feitas nas modelagens das usinas incentivadas que estavam modeladas para agentes convencionais. Assim, a energia incentivada passou a ser representada apenas pelo agente vinculado.

Para o caso dos Geradores, além da separação entre energia convencional e energia incentivada, foi necessária também a separação entre a energia incentivada proveniente de usinas com desconto definido em ato autorizativo de 50\% e energia incentivada proveniente de usinas com desconto de $100 \%$, por meio da criação de um agente incentivado para cada percentual de desconto.

Essa medida foi estabelecida a fim de minimizar os impactos nos descontos para os agentes compradores de energia incentivada (caso as usinas estivessem modeladas em um mesmo agente, o desconto a ser repassado ao comprador seria afetado, pois consistiria em um mix de descontos de 50 e 100\%).

Ao efetuar a modelagem conforme demonstrado na figura 8 é possível garantir que os Agentes vinculados e Incentivados vendam somente energia incentivada, não afetando as vendas de energia convencional realizadas pelo Agente Principal. 
A modelagem feita de forma separada como indicado na figura 9 , possibilita que os consumidores especiais somente comprem energia incentivada, uma vez que eles têm a obrigatoriedade de comprar energia incentivada.

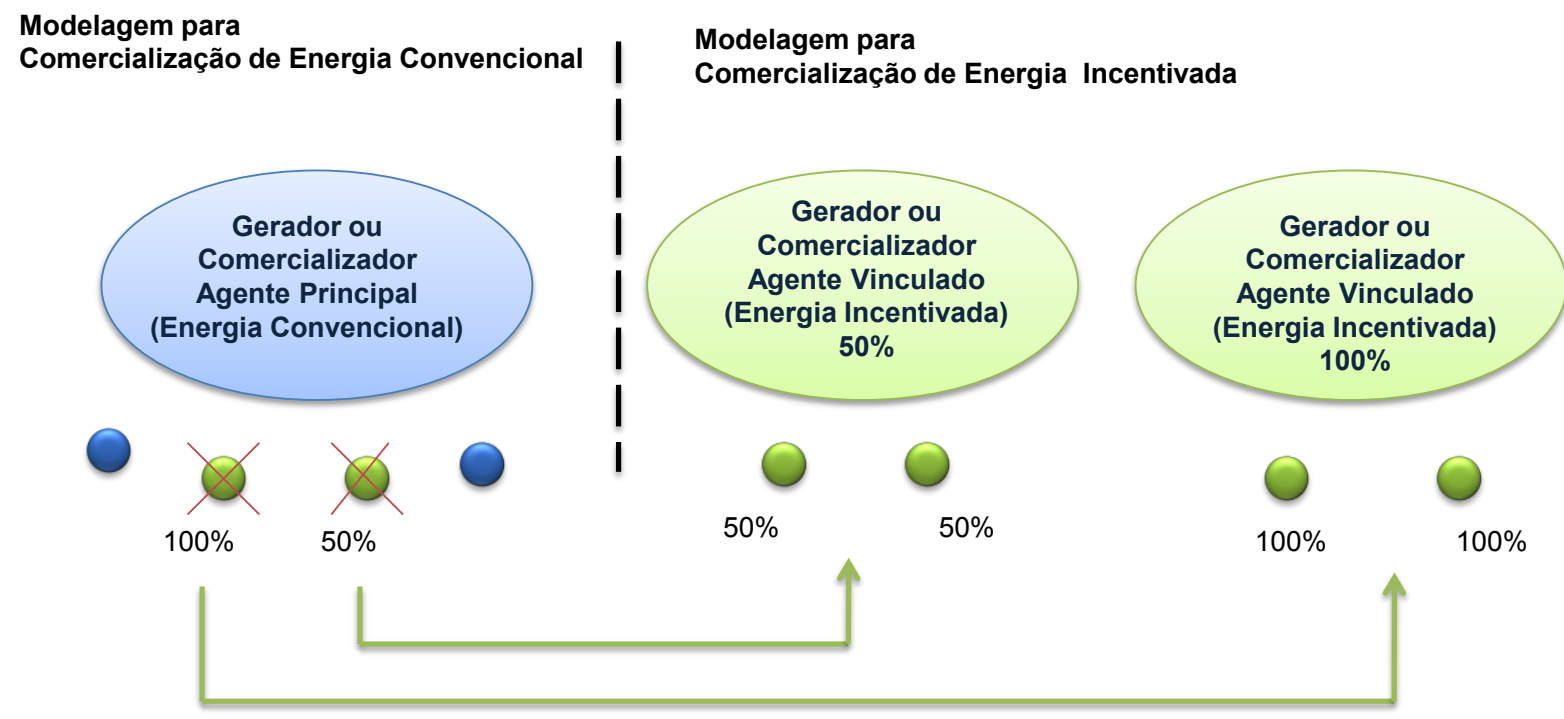

Figura 8: Representação da Modelagem do Gerador ou Comercialização para comercialização de energia convencional e energia incentivada.

Fonte: Elaboração própria utilizando os conceitos do Treinamento de Comercialização de Energia incentivada [6].

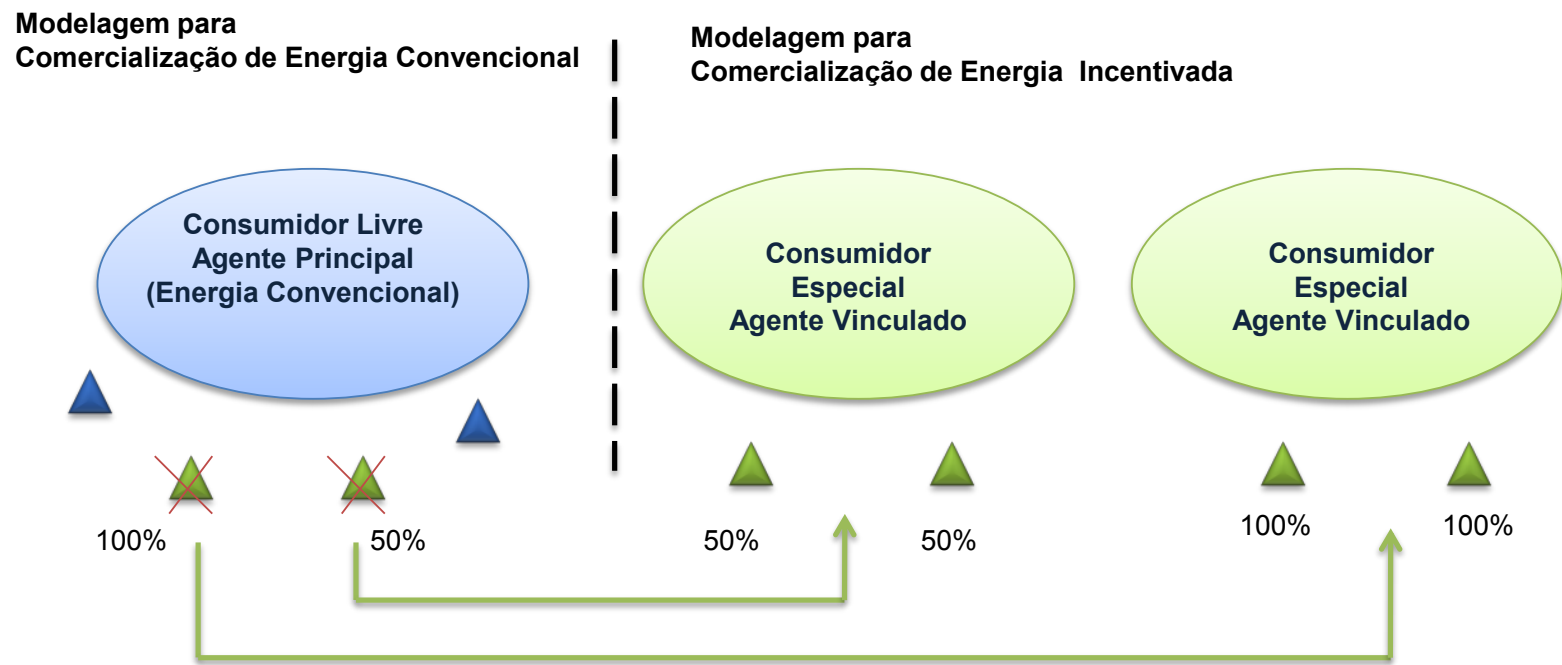

Figura 9: Representação da Modelagem Consumidor Livre para comercialização de energia convencional e do Consumidor Especial energia para comercialização de energia incentivada. Fonte: Elaboração própria utilizando os conceitos do Treinamento de Comercialização de Energia incentivada [6]. 
Ressalte-se que os consumidores que optarem pela comercialização exclusivamente de energia incentivada serão considerados agentes principais.

A figura 10, a seguir, ilustra as relações comerciais, de forma simplificada, envolvendo a energia incentivada. Os vendedores de energia incentivada, em verde, vendem exclusivamente energia incentivada, independente de quem seja o comprador. O consumidor especial pode comprar somente energia incentivada.

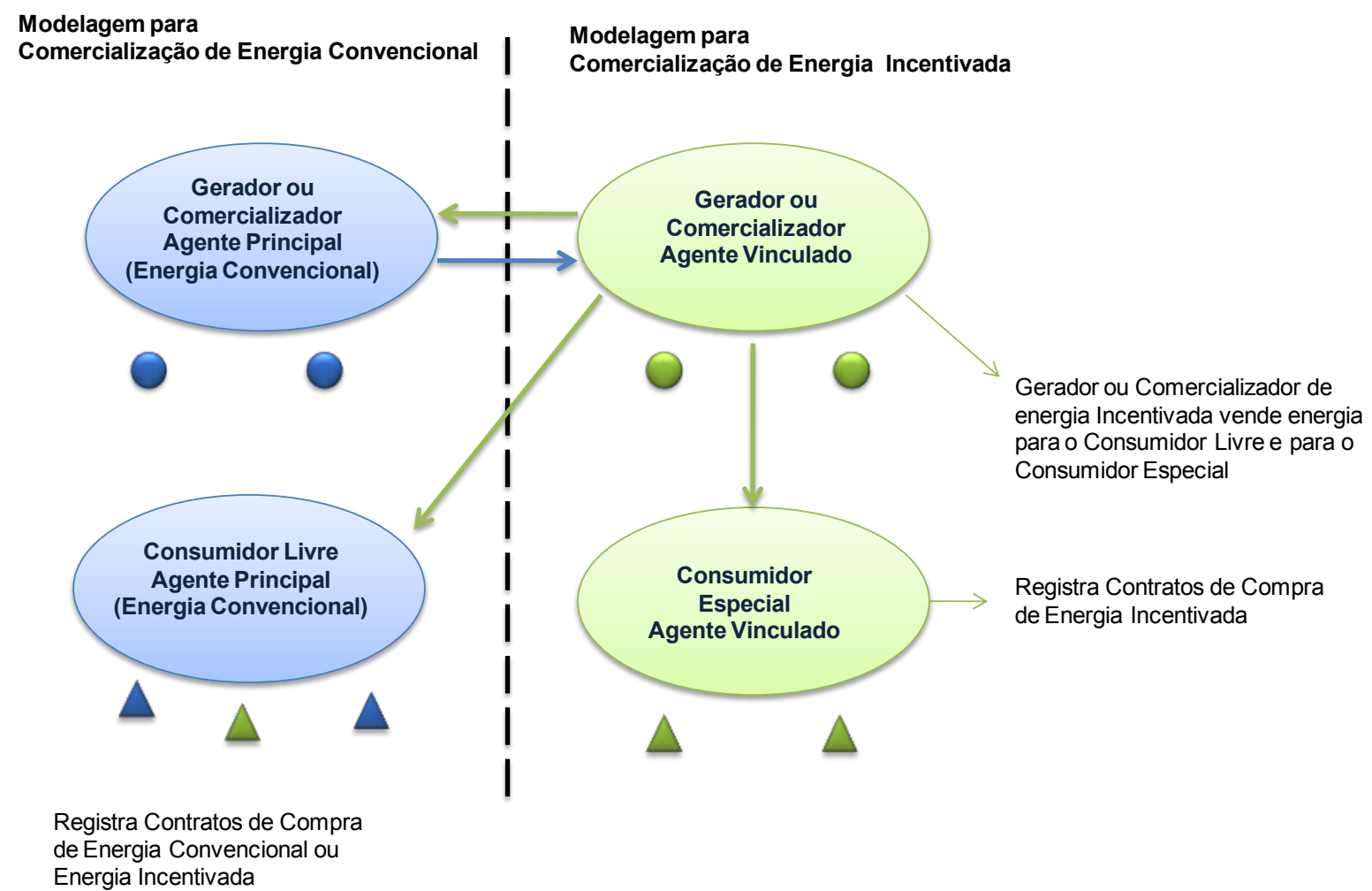

Figura 10: Representação da Modelagem em relações comerciais de forma simplificada envolvendo a energia incentivada.

Fonte: Elaboração própria utilizando os conceitos do Treinamento de Comercialização de Energia incentivada [6].

A energia incentivada adquirida pelo Agente que comercializa energia convencional serve para fins de lastro para o cálculo das penalidades, permitindo sua revenda no caso do gerador ou comercializador, porém não introduz desconto, tendo em vista que o Agente vende exclusivamente energia convencional devido à sua caracterização no perfil de Agente Convencional.

Os vendedores de energia incentivada podem realizar compras de energia convencional, porém a mesma não serve para fins de lastro de penalidades e não 
introduz desconto, servindo apenas para evitar exposições ao Preço de Liquidação das Diferenças.

\subsection{Contratos de Energia Incentivada (CCEl's)}

Os contratos firmados no Ambiente de Contratação Livre (ACL) tem condições de atendimento, preço e demais cláusulas de contratação livremente negociadas entre as partes. Referidos contratos são denominados Contratos de Comercialização no Ambiente Livre (CCEAL) e os contratos negociados a partir de fontes incentivadas de energia são chamados de Contratos de Comercialização de Energia Incentivada (CCEI).

Assim, a comercialização de energia incentivada (Resolução Normativa $\boldsymbol{n}^{\circ}$ 247/2006) implica na celebração de Contrato de Compra de Energia Incentivada (CCEl's), entre o Agente Gerador Incentivado e o Consumidor Especial. Além das cláusulas essenciais a esses contratos administrativos devem ser dispostas: (i) energia elétrica contratada, discriminada por segmentos mensais e/ou anuais; (ii) período de suprimento; (iii) critérios de rescisão; e (iv) submercados de entrega e de consumo.

Todos os contratos CCEl's e suas alterações devem ser registrados na CCEE, de acordo com Decreto $n^{\circ} \mathbf{5 . 1 6 3 / 2 0 0 4}$ (artigo $n^{\circ}$ 53) e a Convenção de Comercialização de Energia Elétrica (artigo $n^{\circ} 7$ ), obedecendo a Procedimentos de Comercialização de Energia. Cabe ressaltar que os preços negociados entre esses agentes no ACL não são objeto de registro na CCEE e são utilizados apenas para fins de negociação entre as partes envolvidas na negociação bilateral do contrato.

Os contratos fimados entre os agentes, tanto no ACR como no ACL, são objeto de verificação de lastro de energia para fins de apuração de penalidades após a contabilização na CCEE.

É importante ressaltar que após a realização do processo de contabilização, as diferenças entre as quantidades de energia contratadas pelos agentes e as quantidades de energia geradas ou consumidas pelos agentes são liquidadas no mercado de curto prazo ao preço da liquidação das diferenças (PLD). 


\subsubsection{Sazonalização e Modulação dos Contratos Bilaterais}

Os contratos firmados no ACL devem ser sazonalizados e modulados para fins de contabilização.

A sazonalização é a distribuição do volume anual de energia negociada nos contratos bilaterais (valendo para convencional e incentivada) em todos os meses do ano e é realizado de acordo com o perfil de entrega, conforme acordado nos contratos bilaterais.

A figura 11, a seguir, representa o processo de sazonalização:

Sazonalização: Montante Anual Contratado $=900 \mathrm{MWh}$ distribuidos ao longo do ano

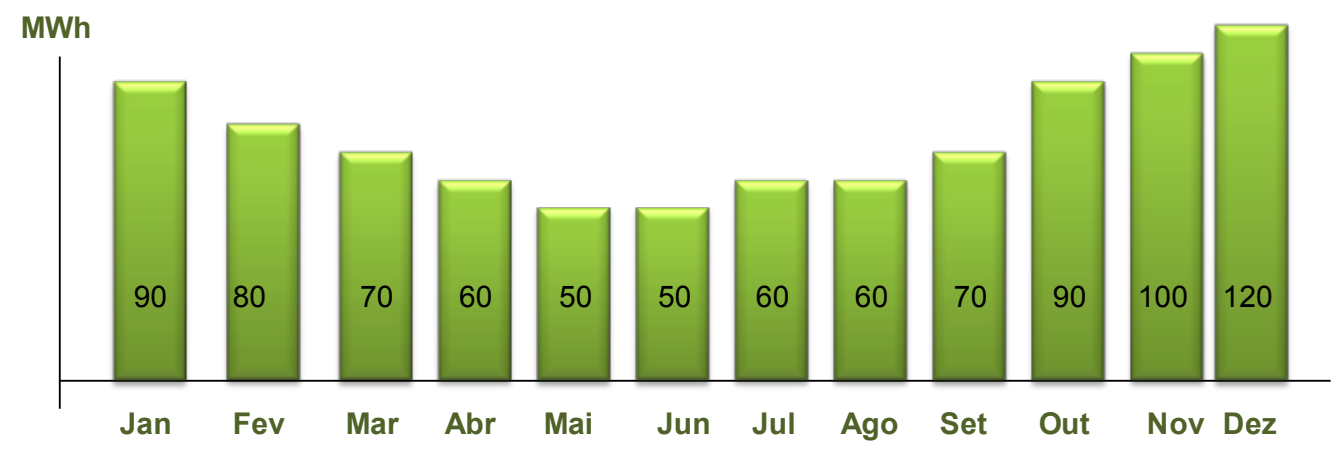

Figura 11: Representação do processo de sazonalização de um contrato bilateral no Ambiente de Contratação Livre (ACL).

Fonte: Elaboração própria utilizando os conceitos das regras e procedimentos de Comercialização de Energia [5].

O processo de sazonalização também poderá ser realizado de forma flat, ou seja, distribuído de forma uniforme ao longo dos meses do ano.

A Modulação é a distribuição do volume mensal de energia por hora ou semanalmente por patamar $^{16}$ de carga, ao longo de cada mês. A modulação também é realizada de acordo com o perfil de entrega, validado pelas partes em acordo com o contrato bilateral firmado.

A figura 12, a seguir, representa o processo de modulação de contrato respeitando os montantes mensais contratados.

\footnotetext{
${ }^{16}$ Patamar de Carga é a classificação das horas do mês, de acordo com o perfil de carga definido pelo ONS podendo ser: (i) Leve (horários de baixo consumo); (ii) Médio (horários de consumo médio); e (iii) Pesado (horários em que se verificam picos de consumo).
} 


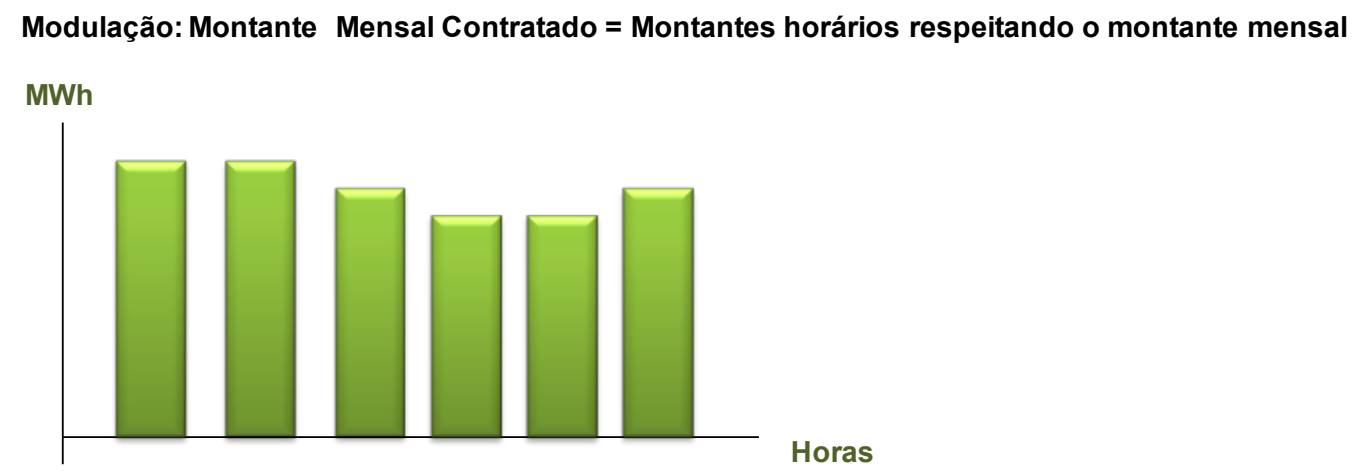

Figura 12: Representação do processo de modulação de um contrato bilateral, respeitados os limites mensais contratados.

Fonte: Elaboração própria utilizando os conceitos das regras e procedimentos de Comercialização de Energia [5].

O processo de modulação também poderá ser realizado de forma flat, ou seja, distribuído de forma uniforme, ao longo das horas do mês, respeitados os limites mensais contratados.

\subsection{Desconto TUSD ou TUST}

\subsubsection{Retrospectiva Normativa}

A Tarifa de Uso do Sistema de Distribuição - TUSD, criada pela Lei $\boldsymbol{n}^{\circ} \mathbf{9 . 0 7 4 / 1 9 9 5}$ art. $n^{\circ} 15$ e $\S 6^{\circ}$, é aplicável ao uso dos sistemas de distribuição de energia elétrica e a Tarifa de Uso do Sistema de Transmissão - TUST resulta do rateio entre os usuários da transmissão, sendo que metade da receita global deve ser paga pelos geradores e a outra metade pelas distribuidoras e consumidores.

Os Artigos $n^{\circ} \mathrm{s} 1^{\circ}$ e $3^{\circ}$ da Resolução Normativa $n^{\circ} \mathbf{7 7}$, de 18 de agosto de 2004, assegurou o direito de $100 \%$ (cem por cento) de redução, a ser aplicado às TUST e TUSD, incidindo na produção e no consumo da energia comercializada, desde que atendam as condições do Artigo $n^{\circ} 1$ da Resolução Normativa $n^{\circ}$ 247/2006, conforme descrito no capítulo sobre consumidores especiais desse trabalho.

A comercialização de energia incentivada sem lastro suficiente acarretará a redução do desconto associado aos contratos vendidos, proporcionalmente à insuficiência de lastro verificada. 
Dessa forma, o desconto na TUSD e na TUST cria uma corrente impactando no repasse dos agentes geradores aos seus consumidores ou dos geradores para os comercializadores e finalmente aos consumidores especiais e, dessa forma, nem sempre o desconto recebido será o estabelecido no ato autorizativo do gerador. Isso ocorre porque a energia incentivada pode ser comercializada livremente e um gerador incentivado pode comprar energia de outro gerador incentivado com desconto inferior ao seu, levando o seu próprio desconto a ser reduzido proporcionalmente, bem como um comercializador que compra energia com desconto reduzido repassará essa redução aos consumidores. Assim, a comercialização de energia incentivada por um agente impacta todos os demais agentes incentivados (geradores, comercializadores e consumidores especiais e consumidores livres que adquirem esta energia incentivada).

Dessa forma, mesmo que o Agente não realize qualquer ação que provoque a perda de seu desconto, o mesmo pode ser impactado pela perda de desconto de outro Agente, até em uma situação em que não haja um contrato bilateral entre ambos. Atualmente, esta perda de desconto é objeto de tratamento externo ao âmbito da CCEE, por meio de mecanismos definidos pelos próprios agentes que comercializaram essa energia.

Dito isto, a eventual redução do desconto associado à energia incentivada vendida por um agente, seja decorrente da ultrapassagem de limite 49\% da Garantia Física apurada na compra de contratos de energia convencional, seja pela ultrapassagem do limite de potência injetada, ou ainda pela comercialização de energia com insuficiência de lastro para venda, será refletida em toda a cadeia de comercialização em que este agente estiver envolvido.

\subsubsection{Metodologia de Repasse do Desconto TUSD /TUST}

As Regras de Comercialização de Energia Elétrica estão inseridas no Módulo de Penalidades das Regras de Comercialização de Energia Elétrica e definem a metodologia de cálculo dos descontos que serão aplicados nas Tarifas de Uso dos sistemas de Distribuição (TUSD) ou Tarifas de Uso do Sistema de Transmissão 
(TUST), para todos os agentes envolvidos na comercialização de energia oriunda de fontes incentivadas.

Neste capítulo, será abordado o detalhamento da metodologia de repasse de descontos na TUSD para os agentes incentivados (geradores, comercializadores e consumidores especiais). Entretanto, mais a frente, no âmbito do subtítulo "Riscos da Comercialização de Energia Incentivada - Perda dos Descontos", será representada a perda desses descontos de forma detalhada, sob a ótica da montagem da matriz de descontos.

A comercialização de energia de fonte convencional não deve produzir desconto na TUSD ou TUST. Importante ressaltar também que participam do cálculo do desconto final somente aqueles agentes que tiverem comercializado energia incentivada no mês do cálculo do desconto.

\subsubsection{Detalhamento da Metodologia de Repasse de Descontos na TUSD para os Agentes Geradores}

Para os agentes da categoria de geração, o desconto associado aos seus contratos de venda será representado por uma média global dos descontos de suas usinas e seus contratos de compra de energia incentivada (CCEl's), calculada pelo quociente entre os descontos ponderados e o máximo entre a garantia física apurada acrescida das quantidades compradas em contratos de energia incentivada (CCEl's), e as quantidades vendidas em contratos de energia incentivada especial.

No caso 1, a seguir, o gerador incentivado possui contratos de compra (CCEl's) acrescido de sua Garantia Física, igual ao montante dos seus contratos de venda de energia incentivada (CCEl's). Assim, verifica-se a seguir que o desconto médio da energia vendida pelo gerador é igual ao desconto médio da energia (comprada e/ou produzida).

Para o caso 2, o gerador possui contratos de compra de energia Incentivada (CCEl's) acrescido de sua garantia física em um montante maior do que os seus contratos de venda de energia incentivada (CCEl's). 
Verifica-se então, a seguir, que o desconto médio da energia vendida pelo gerador também é igual ao desconto médio da energia (comprada e/ou produzida).

\begin{tabular}{|c|c|}
\hline \multicolumn{2}{|c|}{$\begin{array}{c}\text { (1) Garantia Física (GF) + Contratos de } \\
\text { Compra (CCEI Compra) = Contratos de } \\
\text { Venda (CCEI Venda) }\end{array}$} \\
\hline Lastro $=14$ & Vendas $=14$ \\
\hline $\begin{array}{l}\text { Garantia Física = } 10 \\
\text { Desconto }=50 \%\end{array}$ & $\begin{array}{l}\text { CCEI = } 6 \\
\text { Desconto = ? }\end{array}$ \\
\hline $\begin{array}{l}\text { CCEI compra }=4 \\
\text { Desconto }=50 \%\end{array}$ & $\begin{array}{l}\text { CCEI }=8 \\
\text { Desconto = ? }\end{array}$ \\
\hline
\end{tabular}

\begin{tabular}{|c|c|}
\hline \multicolumn{2}{|c|}{$\begin{array}{c}\text { (2) Garantia Física (GF) + Contratos de } \\
\text { Compra (CCE Compra) }>\text { Contratos de } \\
\text { Venda (CCE Venda) }\end{array}$} \\
\hline Lastro $=14$ & Vendas $=8$ \\
\hline $\begin{array}{l}\text { Garantia Física }=10 \\
\text { Desconto }=50 \%\end{array}$ & $\begin{array}{l}\text { CCEI = } 4 \\
\text { Desconto = ? }\end{array}$ \\
\hline $\begin{array}{l}\text { CCEI compra }=4 \\
\text { Desconto }=50 \%\end{array}$ & $\begin{array}{l}\mathrm{CCEI}=4 \\
\text { Desconto = ? }\end{array}$ \\
\hline
\end{tabular}

Tabela 1: Exemplo de Cálculo de fator de desconto na Tarifa de Transporte para Energia Incentivada Comercializada por Agentes Geradores - Caso (1) Garantia Física (GF) + Contratos de Compra $($ CCEI Compra) $=$ Contratos de Venda (CCEI Venda) e Caso (2) Garantia Física (GF) + Contratos de Compra (CCEI Compra) > Contratos de Venda (CCEI Venda), respectivamente.

Fonte: Elaboração própria a partir de informações pela CCEE (www.ccee.org.br).

Caso (1) Desconto $=\frac{10 * 0,5+4 * 0,5}{8+6}=50 \%$

Caso (2) Desconto $=\frac{10 * 0,5+4 * 0,5}{10+4}=50 \%$

Equações: Caso (1) Garantia Física (GF) + Contratos de Compra (CCEI Compra) = Contratos de Venda (CCEI Venda) e Caso (2) Garantia Física (GF) + Contratos de Compra (CCEI Compra) > Contratos de Venda (CCEI Venda), respectivamente.

Fonte: Elaboração própria a partir de informações pela CCEE (www.ccee.org.br).

Na seqüência, analisam-se os casos em que os geradores incentivados possuem energia comprada e/ou produzida (garantia física) em montante inferior ao vendido em contratos de venda de energia incentivada (CCEl's).

No caso 3 a seguir, o agente gerador incentivado possui contratos de compra de energia incentivada (CCEl's), acrescido de sua garantia física, em montante inferior aos seus contratos de venda de energia incentivada. Por consequência da venda a maior, o gerador incentivado sofre uma redução de desconto proporcional à sua insuficiência de lastro de energia.

Já no caso 4, observa-se também que o desconto associado à sua garantia física é de $0 \%$ e que ainda contratou energia incentivada com desconto associado de $50 \%$. Assim, verifica-se que o desconto final desse gerador será associado ao lastro com desconto. 


\begin{tabular}{|c|c|}
\hline \multicolumn{2}{|c|}{$\begin{array}{c}\text { (3) Garantia Física (GF) + Contratos de } \\
\text { Compra (CCE Compra) < Contratos de } \\
\text { Venda (CCE Venda) }\end{array}$} \\
\hline Lastro $=14$ & Vendas $=16$ \\
\hline $\begin{array}{l}\text { Garantia Física = } 10 \\
\text { Desconto }=50 \%\end{array}$ & $\begin{array}{l}\mathrm{CCEI}=8 \\
\text { Des conto = ? }\end{array}$ \\
\hline $\begin{array}{l}\text { CCEI compra }=4 \\
\text { Desconto }=50 \%\end{array}$ & $\begin{array}{l}\mathrm{CCEI}=8 \\
\text { Desconto = ? }\end{array}$ \\
\hline
\end{tabular}

\begin{tabular}{|c|c|}
\hline \multicolumn{2}{|c|}{$\begin{array}{c}\text { (4) Garantia Física (GF) desconto }=0 \%+ \\
\text { Contratos de Compra (CCE Compra) }< \\
\text { Contratos de Venda (CCE Venda) }\end{array}$} \\
\hline Lastro $=14$ & Vendas $=16$ \\
\hline $\begin{array}{l}\text { Garantia Física }=10 \\
\text { Desconto }=0 \%\end{array}$ & $\begin{array}{l}\mathrm{CCEI}=8 \\
\text { Desconto = ? }\end{array}$ \\
\hline $\begin{array}{l}\text { CCEI compra }=4 \\
\text { Des conto }=50 \%\end{array}$ & $\begin{array}{l}\text { CCEI = } 8 \\
\text { Desconto = ? }\end{array}$ \\
\hline
\end{tabular}

Tabela 2: Exemplo de Cálculo de fator de desconto na Tarifa de Transporte para Energia Incentivada Comercializada por Agentes Geradores - Caso (3) Garantia Física (GF) + Contratos de Compra (CCEI Compra) < Contratos de Venda (CCEIVenda) e Caso (4) Garantia Física (GF) + Contratos de Compra (CCEI Compra) < Contratos de Venda (CCEI Venda [Desconto da usina $=0 \%$, respectivamente.

Fonte: Elaboração própria a partir de informações pela CCEE (www.ccee.org.br).

Caso (3) Desconto $=\frac{10 * 0,5+4 * 0,5}{8+8}=43,75 \%$

Caso (4)Desconto $=\frac{10 * 0+4 * 0,5}{8+8}=12,75 \%$

Equações: Caso (3) Garantia Física (GF) + Contratos de Compra (CCEI Compra) < Contratos de Venda (CCEI Venda) e Caso (4) Garantia Física (GF) + Contratos de Compra (CCEI Compra) < Contratos de Venda (CCEI Venda [Desconto da usina $=0 \%$ ], respectivamente.

Fonte: Elaboração própria a partir de informações pela CCEE (www.ccee.org.br).

\subsubsection{Detalhamento da Metodologia de Repasse de Descontos na TUSD para os Agentes Comercializadores}

Para os agentes da categoria dos comercializadores, o desconto associado aos contratos de venda será representado por uma média global dos descontos de seus contratos de compra de energia incentivada (CCEl's), calculada pelo quociente entre os descontos ponderados do lado do comprador e o máximo entre as quantidades compradas em contratos de compra de energia incentivada (CCEl's), e as quantidades vendidas em contratos de energia incentivada (CCEl's).

No caso 01 a seguir, verifica-se que o comercializador possui contratos de compra de energia incentivada (CCEl's) em montante de energia igual aos seus contratos de compra e venda de energia incentivada (CCEl's). Com isso, obviamente o desconto médio da energia vendida por este comercializador é igual ao desconto médio da energia comprada. 
Para o caso 2 a seguir, o comercializador possui contratos de compra de energia incentivada (CCEl's) em montante maior que suas vendas. Assim, novamente o seu desconto médio é igual ao desconto médio da energia comprada.

Já no caso 3, o comercializador possui contratos de compra de energia incentivada (CCEl's) em um montante inferior aos seus contratos de venda de energia incentivada (CCEl's). Por esta razão, o desconto associado será reduzido proporcionalmente à sua insuficiência de lastro de energia.

\begin{tabular}{|c|c|}
\hline \multicolumn{2}{|c|}{$\begin{array}{l}\text { (1) Contratos de Compra (CCECompra) } \\
\text { Contratos de Venda (CCEVenda) }\end{array}$} \\
\hline Lastro $=8$ & Vendas $=8$ \\
\hline $\begin{array}{l}\text { CCEI compra }=6 \\
\text { Desconto }=50 \%\end{array}$ & $\begin{array}{l}\mathrm{CCEI}=4 \\
\text { Des conto = ? }\end{array}$ \\
\hline $\begin{array}{l}\text { CCEI compra }=2 \\
\text { Desconto }=50 \%\end{array}$ & $\begin{array}{l}\mathrm{CCEI}=4 \\
\text { Desconto = ? }\end{array}$ \\
\hline
\end{tabular}

\begin{tabular}{l}
$\begin{array}{l}\text { (2) Contratos de Compra (CCEICompra) } \\
\text { Contratos de Venda (CCEVenda) }\end{array}$ \\
$\begin{array}{ll}\text { Lastro }=\mathbf{8} & \text { Vendas }=\mathbf{6}\end{array}$ \\
$\begin{array}{ll}\text { CCEI compra }=6 & \text { CCEI }=4 \\
\text { Desconto }=50 \% & \text { Desconto }=? \\
\text { CCEI compra }=2 & \text { CCEI }=2 \\
\text { Desconto }=50 \% & \text { Desconto }=?\end{array}$ \\
\hline
\end{tabular}

\begin{tabular}{|c|c|}
\hline \multicolumn{2}{|c|}{$\begin{array}{c}\text { (3) Contratos de Compra (CCEICompra) }< \\
\text { Contratos de Venda (CCEVenda) }\end{array}$} \\
\hline Lastro $=8$ & Vendas $=10$ \\
\hline $\begin{array}{l}\text { CCEI compra }=6 \\
\text { Desconto }=50 \%\end{array}$ & $\begin{array}{l}\mathrm{CCEI}=4 \\
\text { Desconto = ? }\end{array}$ \\
\hline $\begin{array}{l}\text { CCEI compra }=2 \\
\text { Desconto }=50 \%\end{array}$ & $\begin{array}{l}\mathrm{CCEI}=6 \\
\text { Desconto =? }\end{array}$ \\
\hline
\end{tabular}

Tabela 3: Exemplo de Cálculo de fator de desconto na Tarifa de Transporte para Energia Incentivada Comercializada por Agentes Comercializadores - Caso (1) Contratos de Compra (CCEI Compra) = Contratos de Venda (CCEI Venda), Caso (2) Contratos de Compra (CCEI Compra) $>$ Contratos de Venda (CCEI Venda) e Caso (3) Contratos de Compra (CCEI Compra) < Contratos de Venda (CCEI Venda), respectivamente.

Fonte: Elaboração própria a partir de informações pela CCEE (www.ccee.org.br)

Caso (1) Desconto $=\frac{6 * 0,5+2 * 0,5}{4+4}=50 \%$

Caso (2) Desconto $=\frac{6 * 0,5+2 * 0,5}{6+2}=50 \%$

Caso (3) Desconto $=\frac{6 * 0,5+2 * 0,5}{4+6}=40 \%$

Equações: Caso (1) Contratos de Compra (CCEI Compra) = Contratos de Venda (CCEI Venda), Caso (2) Contratos de Compra (CCEI Compra) > Contratos de Venda (CCEI Venda) e Caso (3) Contratos de Compra (CCEI Compra) < Contratos de Venda (CCEI Venda), respectivamente.

Fonte: Elaboração própria a partir de informações pela CCEE (www.ccee.org.br).

\subsubsection{Detalhamento da Metodologia de Repasse de Descontos na TUSD para os Agentes Consumidores Livres e Consumidores Especiais}

Para os consumidores livres e especiais, o desconto a ser aplicado na TUSD/TUST será a média global dos descontos de seus contratos de compra de energia 
incentivada (CCEl's), calculada pelo quociente entre os descontos ponderados pelo lado do comprador e o máximo entre a quantidade total contratada ou o consumo mensal verificado.

Para o caso do consumidor 1 , verifica-se que seu consumo de energia é igual à quantidade de energia comprada por meios dos contratos de compra de energia incentivada (CCEl's). Com isso, verifica-se que o seu desconto final é igual ao desconto médio da energia comprada.

No caso 2, o consumidor realizou contratos de compra de energia incentivada (CCEl's) e também um contrato de compra de energia com desconto igual a $0 \%$. Por consequência dessa compra de energia, sem direito ao desconto na TUSD/TUST, o desconto final será inferior à média ponderada dos seus descontos.

Finalmente, no caso 3, o consumidor consumiu mais energia do que comprou, possuindo assim, insuficiência de cobertura contratual de consumo. Em decorrência, dessa insuficiência, o seu desconto final será inferior à média ponderada dos descontos.

\begin{tabular}{|c|c|}
\hline \multicolumn{2}{|c|}{$\begin{array}{l}\text { (1) Contratos de Compra (CCEI Compra) }= \\
\text { Contratos de Venda (CCENenda) }\end{array}$} \\
\hline Lastro $=8$ & Consumo $=8$ \\
\hline $\begin{array}{l}\text { CCEI compra }=6 \\
\text { Desconto }=50 \%\end{array}$ & \multirow{2}{*}{$\begin{array}{l}\text { Consumo }=8 \\
\text { Desconto }=?\end{array}$} \\
\hline $\begin{array}{l}\text { CCEI compra }=2 \\
\text { Desconto }=50 \%\end{array}$ & \\
\hline
\end{tabular}

\begin{tabular}{|c|c|}
\hline \multicolumn{2}{|c|}{$\begin{array}{l}\text { (2) Contratos de Compra (CCEl Compra) }+ \\
\text { Contratos de Compra (Energia convencional) }\end{array}$} \\
\hline Lastro $=10$ & Consumo $=10$ \\
\hline $\begin{array}{l}\text { CCEI compra }=6 \\
\text { Des conto }=50 \%\end{array}$ & \multirow{3}{*}{$\begin{array}{c}\text { CCEI }=10 \\
\text { Desconto }=?\end{array}$} \\
\hline $\begin{array}{l}\text { CCEI compra }=2 \\
\text { Desconto }=50 \%\end{array}$ & \\
\hline $\begin{array}{l}\text { CCEI compra }=2 \\
\text { Desconto }=0 \%\end{array}$ & \\
\hline
\end{tabular}

\begin{tabular}{l}
$\begin{array}{l}\text { (3) Contratos de Compra (CCEI Compra) }+ \\
\text { Insuficiência de Cobertura Contratual de } \\
\text { Consumo }\end{array}$ \\
\begin{tabular}{l|} 
Lastro $=8$ \\
Consumo $=9$
\end{tabular} \\
$\begin{array}{l}\text { CCEI compra }=6 \\
\text { Desconto }=50 \%\end{array}$ \\
$\begin{array}{l}\text { CCEI }=9 \\
\text { CCEI compra }=2 \\
\text { Desconto }=50 \%\end{array}$ \\
\hline
\end{tabular}

Tabela 4: Exemplo de Cálculo de fator de desconto na Tarifa de Transporte para Energia Incentivada Comercializada por Agentes Consumidores Livres e Consumidores Especiais - Caso (1)

Consumidores Especiais: Contratos de Compra (CCEICompra) = Contratos de Venda (CCEIVenda), Caso (2) Consumidores Livres e Especiais: Contratos de Compra (CCEICompra) + Contratos de Compra (CCCompra Energia Convencional ) e Caso (3) Consumidores Livres e Especiais: Contratos de Compra (CCEICompra) + Insuficiência de Cobertura contratual de Consumo, respectivamente. Fonte: Elaboração própria a partir de informações pela CCEE (www.ccee.org.br).

$$
\begin{aligned}
& \text { Caso (1) Desconto }=\frac{6 * 0,5+2 * 0,5}{6+2}=50 \% \\
& \text { Caso (2) Desconto }=\frac{6 * 0,5+2 * 0,5+2 * 0}{6+2+2}=40 \% \\
& \text { Caso (3) Desconto }=\frac{6 * 0,5+2 * 0,5}{9}=44,44 \%
\end{aligned}
$$


Equações: Caso (1) Consumidores Especiais: Contratos de Compra (CCEI Compra) $=$ Contratos de Venda (CCEI Venda), Caso (2) Consumidores Livres e Especiais: Contratos de Compra (CCEI Compra) + Contratos de Compra (Contrato Compra Energia Convencional ) e Caso (3) Consumidores Livres e Especiais: Contratos de Compra (CCEI Compra) + Insuficiência de cobertura contratual de Consumo, respectivamente.

Fonte: Elaboração própria a partir de informações pela CCEE (www.ccee.org.br)

\subsection{Matriz de Descontos}

\subsubsection{Formulação e Equacionamento Matemático}

Como consequência do resultado da negociação da comercialização de energia incentivada, agentes podem ser impactados pelo resultado da apuração do desconto na TUSD ou TUST. Para entender melhor a questão da perda dos descontos pelos agentes, é necessário entender como é feita a matriz de descontos, conforme se detalha a seguir.

A CCEE calcula mensalmente o desconto final de todos os agentes envolvidos na comercialização de energia incentivada. As regras para esse cálculo adotam a técnica de solução de sistemas de equações lineares, via abordagem matricial.

Em maior detalhe, para a solução do problema do tipo $\mathbf{A}^{*} \mathbf{d}=\mathbf{b}, \mathbf{A}$ é a matriz de comercialização de energia incentivada; $\mathbf{d}$ é o vetor de descontos e $\mathbf{b}$ é vetor de disponibilidades de desconto. A solução inclui quatro passos: (i) montar a matriz $A$; (ii) obter a matriz inversa de $A$; (iii) montar o vetor b; (iv) calcular o vetor $d=A^{-1}$.b.

Assim, a equação $A^{*} d=b$, pode ser escrita conforme segue:

$\left[\begin{array}{cccc}a_{11} & a_{12} & \ldots & a_{1 n} \\ a_{21} & a_{22} & \ldots & a_{2 n} \\ a_{n 1} & a_{n 2} & \ldots & a_{n n}\end{array}\right] *\left[\begin{array}{c}d_{1} \\ d_{2} \\ \cdot \\ \cdot \\ d_{n}\end{array}\right]=\left[\begin{array}{c}b_{1} \\ b_{2} \\ \cdot \\ \cdot \\ b_{n}\end{array}\right]$

Para reprodutibilidade das regras, a CCEE deve disponibilizar aos agentes a matriz A e os vetores $d$ e $b$.

$\mathrm{O}$ processo de construção da matriz $\mathrm{A}$ e os vetores $\mathrm{d}$ e $\mathrm{b}$ está detalhadamente descrito a seguir: 
A matriz A (matriz de comercialização de energia incentivada) é composta tendo sua ordem igual ao número de agentes envolvidos na comercialização da energia incentivada.

Cada agente possui uma posição específica na matriz de comercialização de energia incentivada. Assim, cada elemento " $a_{i j}$ " da linha da matriz corresponde a um agente Gerador, comercializador ou Consumidor (Consumidor Livre ou Consumidor Especial) que comercializaram energia incentivada nos últimos doze meses.

A diagonal principal é composta pelo maior valor entre o lastro do agente e a energia comprometida com contratos de venda, ou seja, para os agentes vendedores considera-se o maior valor entre a sua Garantia Física acrescida dos contratos de compra de energia incentivada comparada aos contratos de venda e para os consumidores, o maior valor entre seus contratos de compra de energia incentivada e o seu consumo.

Os elementos fora da diagonal principal (índices "i” ₹ "j") são compostos pela relação comercial entre agente comprador "i" e o agente vendedor "j" , ou seja, o agente "i" comprou de "j". Correspondente valor é preenchido com sinal invertido (negativo) em razão da lógica inerente ao algoritmo de solução.

Da matriz A, a seguir, "n" corresponde ao número de agentes envolvidos na comercialização de energia incentivada.

$A=\left[\begin{array}{lll}a_{11} & a_{12} \ldots & a_{1 n} \\ a_{21} & a_{22} \ldots & a_{2 n} \\ a_{n 1} & a_{n 2} \ldots & a_{n n}\end{array}\right]$

Se “i” ₹ “j”, os elementos estão localizados fora da diagonal principal e se tem que:

$a_{i j}=-1$ * total de energia incentivada que o agente "i" comprou de "j" nos últimos doze meses

Por outro lado, se “i”" = “j”, os elementos estão localizados na diagonal principal e se pode denotar que:

- Agente Gerador

aii = máx [Garantia Física incentivada úlitimos 12 meses + CCEI Compra ütimos 12 moses; CCEI Venda üttimos 12 meses] 
- Agente Comercializador:

aii = máx[CCEI Compra últimos 12 meses; CCEI Venda últimos 12 meses]

- Consumidor Livre ou Especial:

aii = máx[CCEl Compra últimos 12 meses + CCEAL Compras Convencional últimos 12 meses; Consumo últimos 12 meses]

O vetor $\mathbf{b}$ (vetor de disponibilidades de desconto)pode ser denotado como:

$b=\left[\begin{array}{c}b_{1} \\ b_{2} \\ \vdots \\ b_{n}\end{array}\right]$

Se o Agente é gerador:

bi = SOMA (Garantia Física Incentivada no mês * Desconto da usina no mês) últimos 12 meses de todas as usinas do Agente

Outros Agentes: $b_{i}=$ zero

O vetor $\mathbf{d}$ (vetor de descontos), por sua vez, pode ser denotado como:

$d=\left[\begin{array}{c}d_{1} \\ d_{2} \\ \vdots \\ d_{n}\end{array}\right]=A^{-1} * b$

Onde: $d_{i}=$ Desconto final do Agente "i".

A seguir, é apresentado um exemplo simplificado da montagem de uma matriz A:

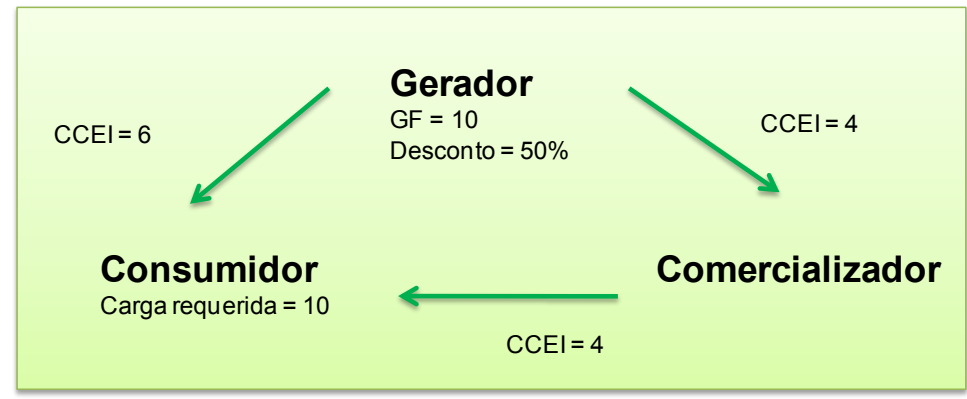

Figura 13: Descontos para a montagem simplificada da montagem da Matriz A. Fonte: Elaboração própria. 
Assim, utilizando o processo de construção, conforme detalhado no início desse capítulo, a matriz A é dada da seguinte forma:

$A=\begin{gathered}\text { Gerador } \\ \text { Comercializador } \\ \text { Consumidor }\end{gathered}\left(\begin{array}{ccc}10 & 0 & 0 \\ -4 & 4 & 0 \\ -6 & -4 & 10\end{array}\right)$

A matriz inversa será:

$$
A^{-1}=\left(\begin{array}{ccc}
0,100 & 0 & 0 \\
0,100 & 0,250 & 0 \\
0,100 & 0,100 & 0,100
\end{array}\right)
$$

O vetor b (vetor de disponibilidades de desconto) será:

$$
b=\left(\begin{array}{l}
5 \\
0 \\
0
\end{array}\right)
$$

Gerador: GF ${ }^{*}$ Desconto $=10 * 50 \%=5$

O vetor d (vetor de desconto) será:

$$
\begin{aligned}
& \boldsymbol{d}=\boldsymbol{A}^{-1} * \boldsymbol{b} \\
& \mathrm{d}=\left(\begin{array}{ccc}
0,100 & 0 & 0 \\
0,100 & 0,250 & 0 \\
0,100 & 0,100 & 0,100
\end{array}\right) *\left(\begin{array}{l}
5 \\
0 \\
0
\end{array}\right)=\left(\begin{array}{l}
0,5 \\
0,5 \\
0,5
\end{array}\right)
\end{aligned}
$$

Assim, o desconto final repassado ao comercializador e ao consumidor do exemplo acima será $50 \%$. 


\subsubsection{Riscos da Comercialização de Energia Incentivada - Perda dos Descontos}

Nesse capítulo será apresentado exemplo de casos em que determinados agentes perderam o desconto e repassaram essa perda a todos os consumidores que compraram essa energia, por meio da montagem da matriz de descontos [6].

Para demonstrar a questão do repasse da perda dos descontos, apresenta-se a seguir um caso principal (Cenário 01), no qual serão simuladas algumas situações:

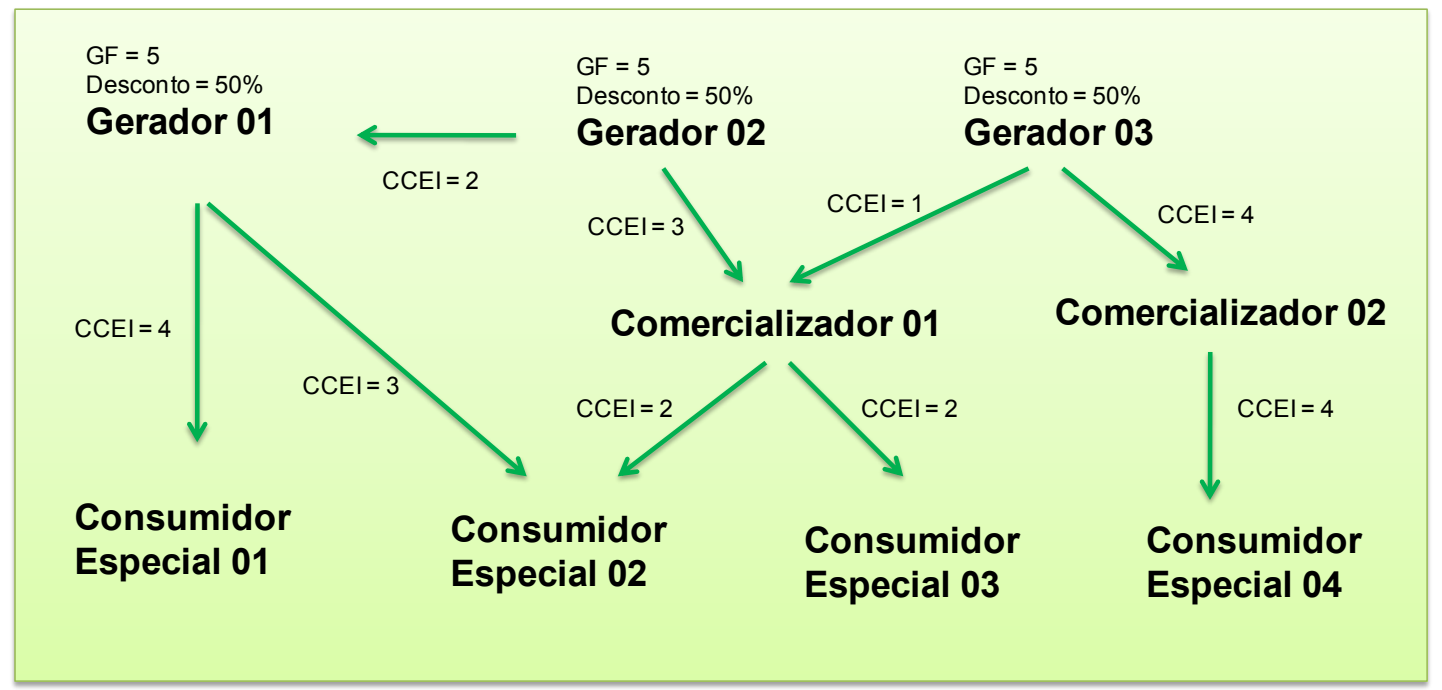

Figura 14: Cenário 01 - Repasse da perda dos descontos

Fonte: Treinamento de Comercialização de Energia incentivada [6].

Em primeiro lugar (cenário 01), consideremos um caso ideal (sem perda de descontos), onde todos geradores possuem o desconto de $50 \%$, todos os agentes possuem energia suficiente para suprir o seu lastro e os consumidores são considerados especiais, ou seja, somente compraram energia incentivada.

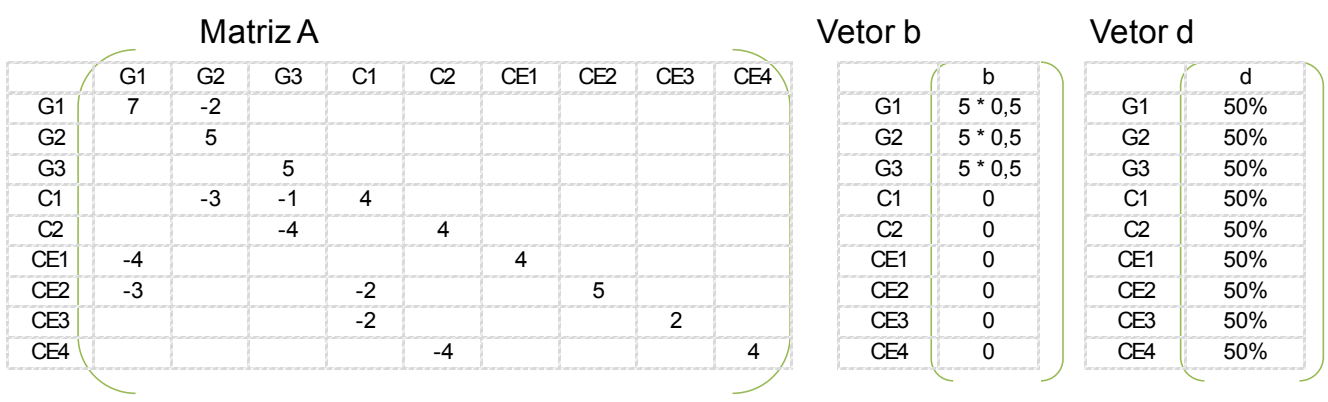


Agora considerando o mesmo cenário 01, porém o consumidor especial 01 não possui lastro suficiente para suprir o seu consumo, seu $\mathrm{CCEI}=4$ e seu consumo $=$ 4,5. Verifica-se então, que o seu desconto será reduzido de $50 \%$ para $44,4 \%$, não afetando o desconto dos demais agentes.

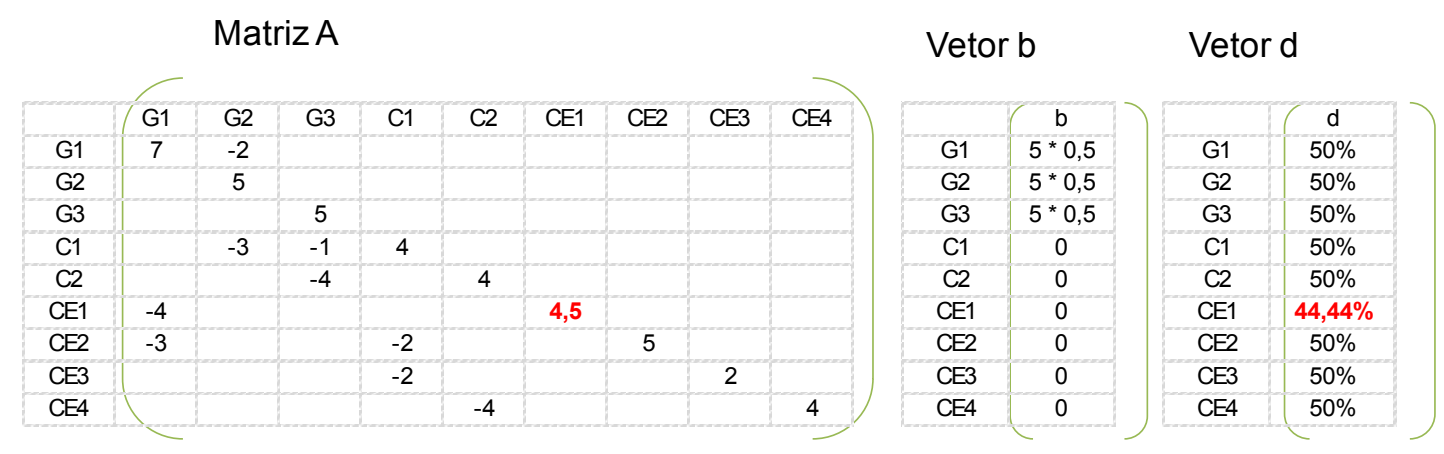

No caso a seguir, apresenta-se o primeiro cenário, porém neste caso o Gerador 03 tem desconto igual a zero.
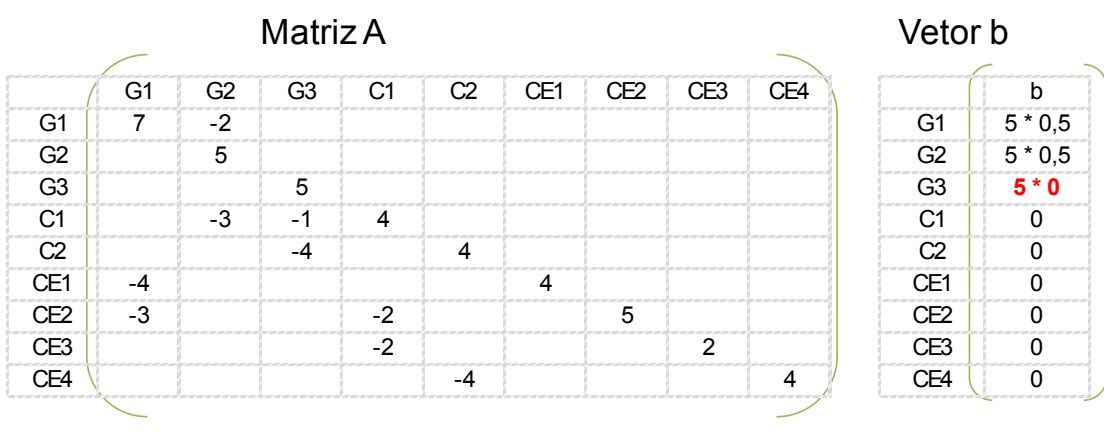

Vetor d

Verifica-se neste caso, que o Gerador 03 perdeu todo o desconto e esta perda impactou o desconto dos compradores que possuem vínculo, direta e ou indiretamente, com essa energia vendida.

Em seguida, analisa-se o cenário 02 , caracterizado na Figura 15 que se segue.

Neste Cenário, foi acrescentado um contrato de venda (CCEI) do Gerador 03 para o Gerador 02, o gerador 02 passa a vender CCEI=5 para o comercializador 01 e 0 Comercializador 01 passa a vender para o Gerador 03. Assim, considerando que o Gerador 03 possui desconto igual a $0 \%$, são apresentados os resultados estampados na equação 23. 


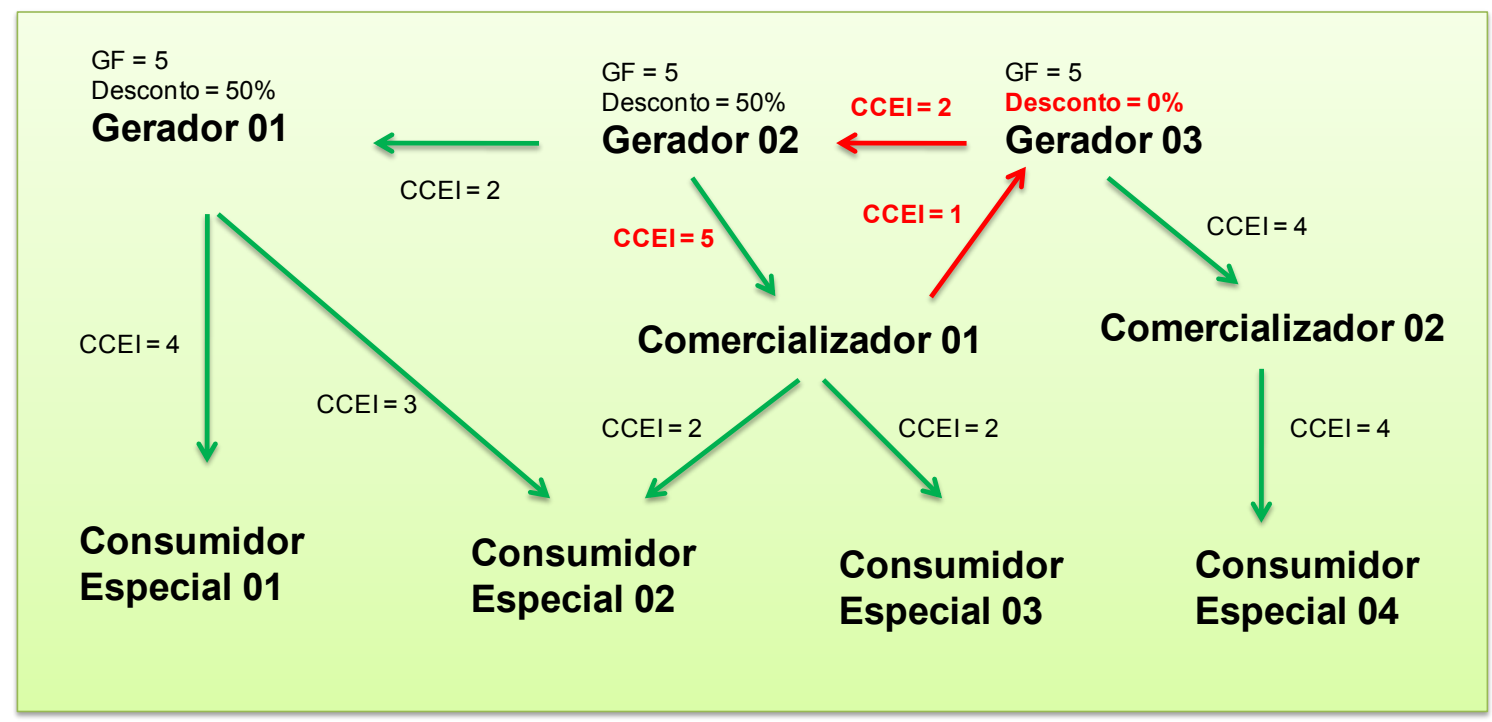

Figura 15: Cenário 02: Repasse da perda dos descontos.

Fonte: Treinamento de Comercialização de Energia incentivada [6].

\begin{tabular}{l|c|c|c|c|c|c|c|c|c|}
\multicolumn{10}{|c|}{ Matriz A } \\
\hline & G1 & G2 & G3 & C1 & C2 & CE1 & CE2 & CE3 & CE4 \\
\hline G1 & 7 & -2 & & & & & & & \\
\hline G2 & & 7 & -2 & & & & & & \\
\hline G3 & & & 6 & -1 & & & & & \\
\hline C1 & & -5 & & 5 & & & & & \\
\hline C2 & & & -4 & & 4 & & & & \\
\hline CE1 & -4 & & & & & 4 & & & \\
\hline CE2 & -3 & & & -2 & & & 5 & & \\
\hline CE3 & & & & -2 & & & & 2 & \\
\hline CE4 & & & & & -4 & & & & 4 \\
\hline
\end{tabular}

\begin{tabular}{|c|c|c|c|}
\hline \multicolumn{2}{|c|}{ Vetor b } & \multicolumn{2}{|c|}{ Vetor d } \\
\hline & $\mathrm{b}$ & & d \\
\hline G1 & $5 * 0,5$ & G1 & $46,43 \%$ \\
\hline G2 & $5 * 0,5$ & G2 & $37,5 \%$ \\
\hline G3 & $5 * 0$ & G3 & $6,25 \%$ \\
\hline $\mathrm{C} 1$ & 0 & $\mathrm{C} 1$ & $37,5 \%$ \\
\hline $\mathrm{C} 2$ & 0 & C2 & $6,25 \%$ \\
\hline CE1 & 0 & CE1 & $46,43 \%$ \\
\hline CE2 & 0 & CE2 & $42,86 \%$ \\
\hline CE3 & 0 & CE3 & $37,5 \%$ \\
\hline CE4 & 0 & CE4 & $6,25 \%$ \\
\hline
\end{tabular}

Em seguida, analisa-se o cenário 03:

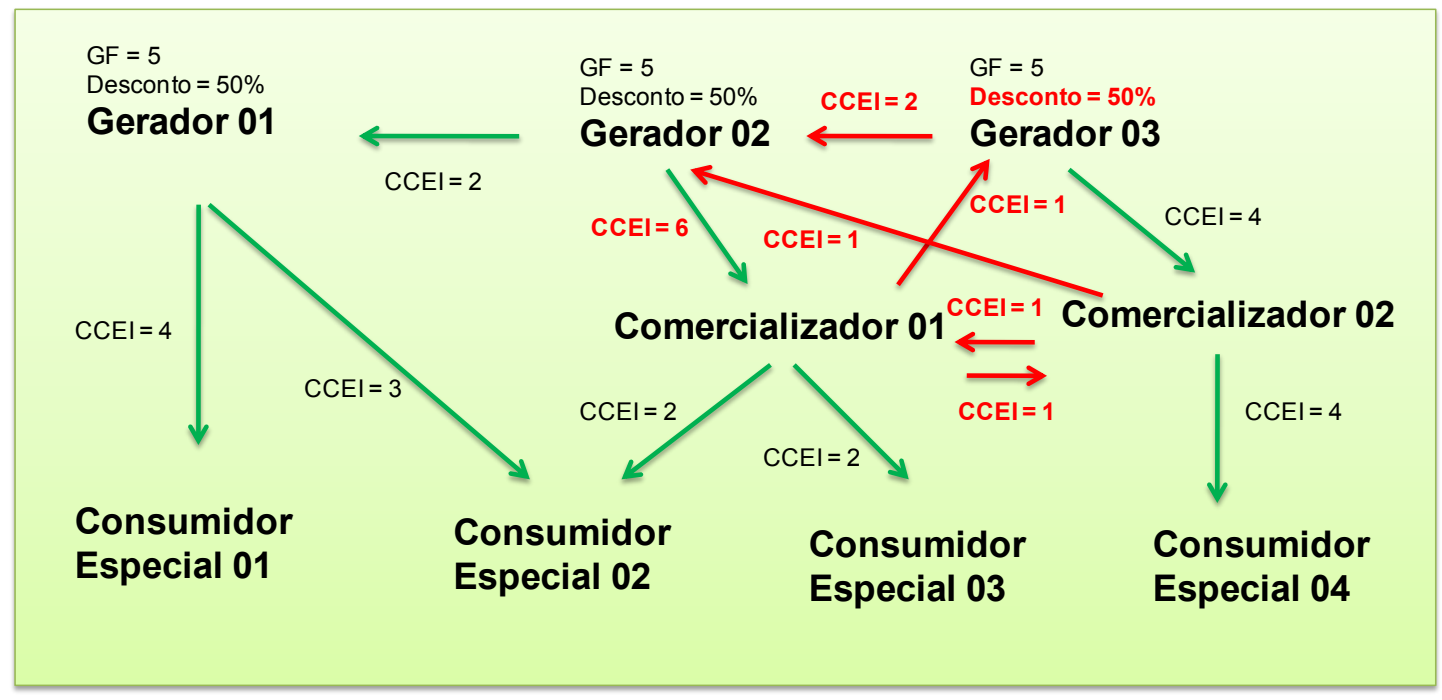

Figura 16: Cenário 03: Demonstração da questão do repasse da perda dos descontos. Fonte: Treinamento de Comercialização de Energia incentivada [6]. 
Por sua vez, no cenário 03 , considerando que o Comercializador 02 possui insuficiência de lastro de venda, resulta:
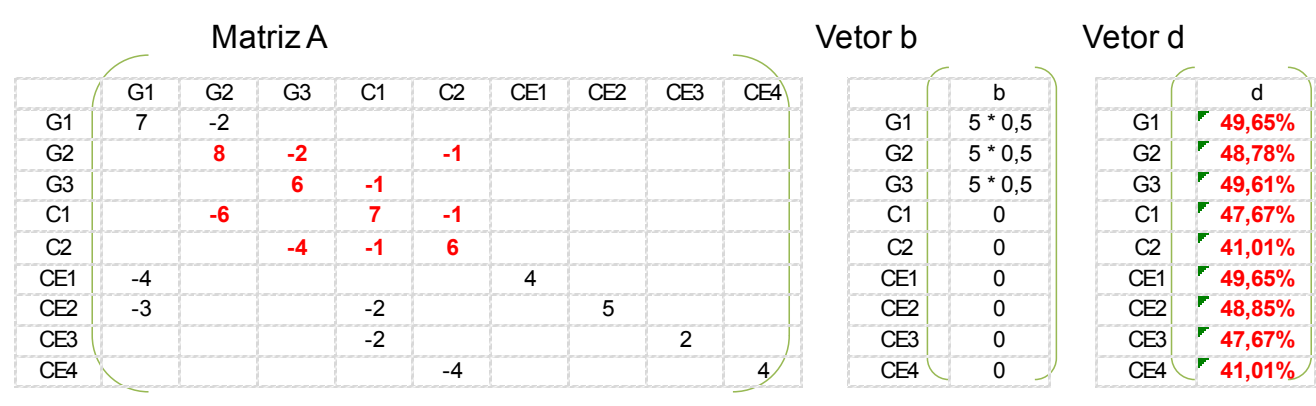

Finalmente, a seguir, continua a se considerar a insuficiência de lastro do comercializador 02 e o desconto do gerador 03, igual a zero.
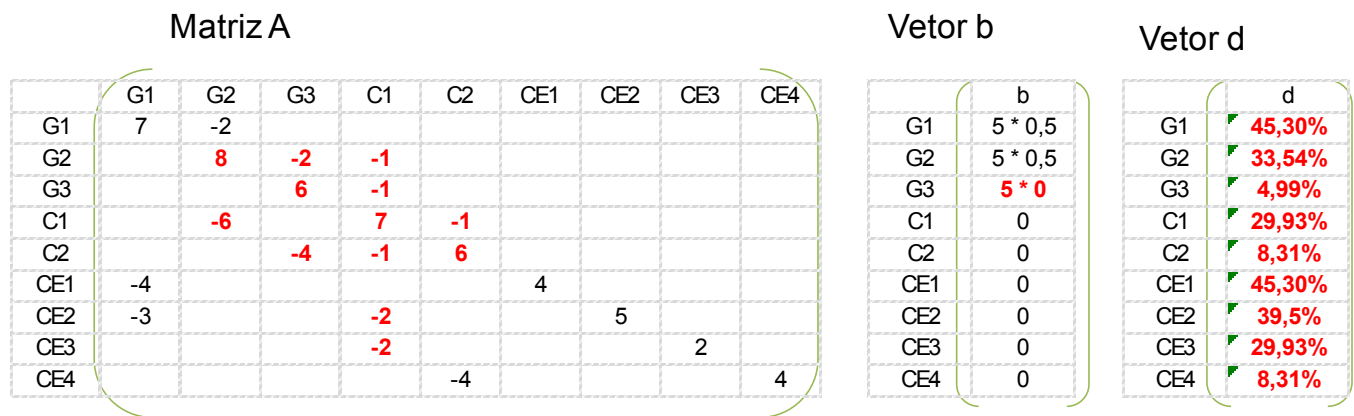

Um ponto importante a ressaltar é que devem ser estudadas formas de aplicação de sanções aos vendedores que proporcionem a perda de desconto, tendo em vista que no âmbito da CCEE não há nenhuma penalidade referente a este comportamento. Ainda, embora haja a possibilidade do mercado se auto-regular, selecionando melhor os fornecedores ou por meio de acordo de ressarcimento caso haja perda do desconto, muitos contratos foram firmados antes da aprovação das regras pela ANEEL.

Outro ponto importante é que em razão da aprovação de Processos de Recontabilização na CCEE, deve-se estudar a possibilidade do Agente recuperar o desconto perdido. 


\subsection{Contabilização}

O Artigo $n^{\circ} 2$, da Convenção de Comercialização de Energia Elétrica, estabelece as condições de comercialização de energia elétrica e as bases de organização, funcionamento e atribuições da Câmara de Comercialização de Energia Elétrica CCEE, incluindo o processo de contabilização e liquidação financeira das operações realizadas no mercado de curto prazo.

O processo de contabilização consiste no registro de todos os contratos de compra e venda de energia elétrica, bem como os dados de medição dos pontos de consumo e geração no Sistema de Contabilização e Liquidação (SCL). Esse sistema efetua todos os cálculos previstos nas regras de comercialização, permitindo à CCEE contabilizar mensalmente as diferenças entre os montantes de energia produzidos ou consumidos e os montantes contratados. Esse cálculo é feito para todos os patamares de carga de todas as semanas do mês contabilizado, tendo dessa forma, o resultado líquido do agente da CCE, ou seja, o montante que terá que pagar ou receber no processo de liquidação financeira.

\subsection{Penalidades}

\subsubsection{Conceitos e Definições}

O Decreto $n^{\circ}$ 5.163/2004 definiu em seus artigos $2^{\circ}$ e $3^{\circ}$ que os consumidores especiais estarão sujeitos a penalidade caso não garantam o atendimento a $100 \%$ de sua carga. A comprovação de Cobertura Contratual de Consumo para os agentes consumidores livres e especiais deve ser feita exclusivamente por meio de compra de energia de geradores/comercializadores de energia incentivada e a Insuficiência de lastro de venda é aplicável aos agentes de geração e de comercialização que não atenderam os requisitos de energia comprometida em contrato.

Para fins de apuração de penalidades por insuficiência de cobertura contratual de consumo e de lastro de venda de agentes vendedores, é promovida a verificação mensal pela CCEE, considerado o histórico de comercialização dos agentes de mercado (consumidores e vendedores) por meio da confrontação de recursos e requisitos dos doze meses precedentes (janela de 12 meses), com exceção dos 
agentes de distribuição, cujo nível de contratação é apurado uma única vez ao ano, no mês de dezembro, observando os valores de consumo e de energia contratada do ano civil.

Ressalte-se que, para o caso dos agentes incentivados, o histórico iniciou a partir de janeiro de 2008, devido à criação dos agentes consumidores especiais na CCEE a partir desta data.

A Convenção de Comercialização, instituída pela Resolução n 109/2004, definiu que a insuficiência de lastro de venda e cobertura contratual de consumo leva a aplicação de multa. Nesse contexto, o valor é obtido através do maior valor entre o Preço Médio da Liquidação das Diferenças e o Valor Anual de Referência (VR) vigentes no mês de apuração da penalidade.

A verificação de atendimento ao lastro integral dos agentes está alinhada à questão da segurança de suprimento, uma vez que o lastro é constituído por garantia física das usinas próprias e/ou por contratos de compra de energia elétrica. Por consequência, a exigência de lastro integral para cada agente leva o sistema a um cenário em que, independentemente da cadeia de comercialização e das relações comerciais formadas, a carga total do sistema não é maior do que o somatório dos valores de garantia física de todas as usinas em operação comercial no SIN.

\subsubsection{Penalidade por Insuficiência de Cobertura Contratual de Consumo}

Conforme já dito, a penalidade por insuficiência de cobertura contratual de consumo é apurada mensalmente, por meio da verificação dos dados de comercialização dos agentes consumidores livres e especiais, confrontando seus recursos e requisitos referentes aos doze meses precedentes.

A figura 17, a seguir, apresenta um exemplo de cálculo da apuração das penalidades por insuficiência de cobertura contratual de consumo para consumidores livres e especiais. Nesta figura é representado um consumidor livre que possui um consumo mensal de energia no montante de $100 \mathrm{MWh}$, pelo que impõe-se realizar a compra de energia para suprir o seu consumo mensal. 
Verifica-se então, que alguns meses o consumidor realizou a compra de energia em montante superior à sua necessidade (fev/08, mar/08 e abr/08) enquanto que nos meses (jan/08 e mai/08) comprou energia em montante inferior ao seu consumo.

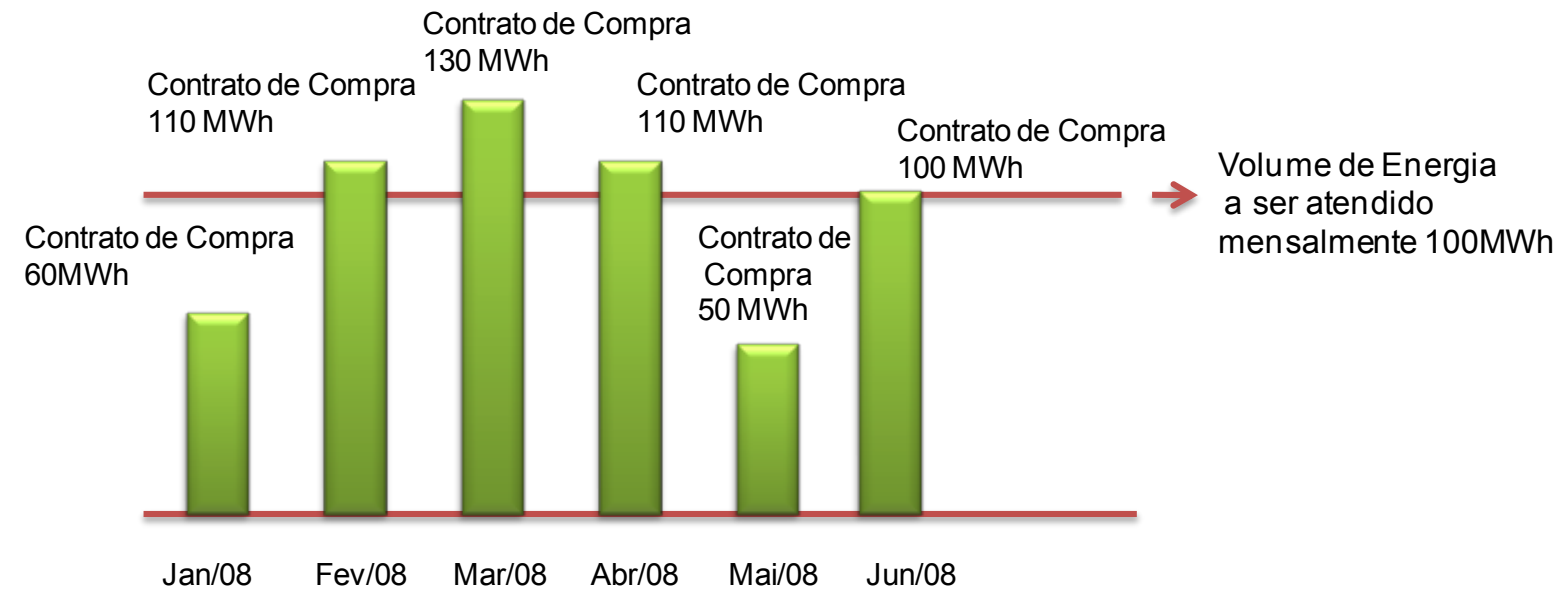

Figura 17: Exemplo de perfil de um consumidor livre ou especial para apuração de penalidade por Insuficiência de Cobertura Contratual de Consumo.

Fonte: Elaboração própria utilizando os conceitos das Regras de Comercialização de Energia da CCEE - Módulo Penalidades.

A partir da figura 17, foi elaborada a tabela a seguir que apresenta os dados numéricos de comercialização de um consumidor livre ou especial, para demonstração do cálculo de apuração de penalidade.

\begin{tabular}{|c|c|c|c|}
\hline \multicolumn{4}{|c|}{ Exemplo de apuração da Penalidade para o Consumidor Livre ou Especial } \\
\hline $\begin{array}{l}\text { Apuração da Penalidade - } \\
\text { Mês da Contabilização }\end{array}$ & $\begin{array}{l}\text { Contrato de } \\
\text { Compra (MWh) }\end{array}$ & $\begin{array}{l}\text { Consumo Mensal } \\
\text { (MWh) }\end{array}$ & $\begin{array}{l}\text { Nível de } \\
\text { Ins uficiência (MWh) }\end{array}$ \\
\hline jan/08 & $\begin{array}{l}\text { sem histórico anterior } \\
\text { ( ano 2007) }\end{array}$ & $\begin{array}{l}\text { sem histórico anterior } \\
\text { (ano 2007) }\end{array}$ & - \\
\hline fev/08 & $60($ jan/08) & $100(\mathrm{jan} / 08)$ & 40 (déficit) \\
\hline $\operatorname{mar} / 08$ & $\begin{array}{l}60(\text { jan/08) + } \\
110(\text { fev/08) = } \\
170\end{array}$ & $\begin{array}{l}100(\text { jan/08) + } \\
100(\text { fev/08) }= \\
200\end{array}$ & $170-200=30$ (déficit) \\
\hline $\mathrm{abr} / 08$ & $\begin{array}{l}60(\text { jan/08) + } \\
110(\text { fev/08) + } \\
130(\text { mar/08) }= \\
300\end{array}$ & $\begin{array}{l}100(\text { jan/08) + } \\
100(\text { fev/08) }+ \\
100(\text { mar/08) }= \\
300\end{array}$ & $300-300=0$ \\
\hline mai/08 & $\begin{array}{l}60(\text { jan/08) + } \\
110(\mathrm{fev} / 08)+ \\
130(\mathrm{mar} / 08)+ \\
110(\mathrm{abr} / 08)= \\
410\end{array}$ & $\begin{array}{l}100(\text { jan/08) + } \\
100(\text { fev/08) + } \\
100(\text { mar/08) + } \\
100(\text { abr/08) }= \\
400\end{array}$ & $410-400=10$ (sobra) \\
\hline
\end{tabular}

Tabela 5: Dados numéricos do consumidor livre ou especial para demonstração do cálculo de apuração de penalidade por Insuficiência de Cobertura Contratual de Consumo.

Fonte: Elaboração própria utilizando os conceitos das Regras de Comercialização de Energia da CCEE - Módulo Penalidades. 
Assim, conforme apresentado na figura 17 e tabela 5, é demonstrado a seguir a finalização do cálculo do valor da penalidade.

Observe que o Preço de Referência para a realização do cálculo do valor da Penalidade é o maior entre o Preço Médio da Liquidação das Diferenças e o Valor de Referência válido para o respectivo ano civil.

Acrescente-se ainda que o valor da penalidade é obtido por meio da confrontação dos recursos e requisitos dos doze meses precedentes, ou seja, realizando a subtração dos recursos todos os seus requisitos, dividindo pelo número de meses do ano e multiplicando pelo maior valor entre o entre o Preço Médio da Liquidação das Diferenças e o Valor de Referência válido para o respectivo ano civil.

\begin{tabular}{|c|c|c|}
\hline \multicolumn{3}{|c|}{ Exem plo do cálculo do Valor da Penalidade } \\
\hline $\begin{array}{l}\text { Apuração da Penalidade - } \\
\text { Mês da Contabilização }\end{array}$ & $\begin{array}{l}\text { Nível de } \\
\text { Insuficiência } \\
\text { (MWh) }\end{array}$ & $\begin{array}{l}\text { Valor da Penalidade } \\
\text { (R\$) }\end{array}$ \\
\hline jan/08 & - & $\begin{array}{c}40 / 12 * 139,44= \\
\mathbf{5 . 5 7 7 , 6 0 0}\end{array}$ \\
\hline fev/08 & 40 (déficit) & $\begin{array}{c}30 / 12 * 139,44= \\
\mathbf{4 . 1 8 3 , 2 0 0}\end{array}$ \\
\hline mar/08 & 30 (déficit) & - \\
\hline abr/08 & 0 & - \\
\hline mai/08 & 10 (sobra) & - \\
\hline
\end{tabular}

Exemplo:

Sendo o valor do VR $(2008)=139,44(R \$)$

Preço Médio da Liquidação das Diferenças $=120,00(R \$)$

Preço de Referência = maior valor entre o VR e Preço Médio da Liquidação das

Diferenças $=139,44(R \$)$

Tabela 6: Dados numéricos do consumidor livre ou especial para demonstração do cálculo do valor da penalidade por Insuficiência de Cobertura Contratual de Consumo.

Fonte: Elaboração própria utilizando os conceitos das Regras de Comercialização de Energia da CCEE - Módulo Penalidades.

\subsubsection{Penalidade por Insuficiência de Lastro de Venda de Energia (Geradores e Comercializadores)}

A figura 18, a seguir, apresenta um exemplo simplificado para o cálculo da apuração das penalidades para o gerador ou comercializador por Insuficiência de Lastro de Venda de Energia: 


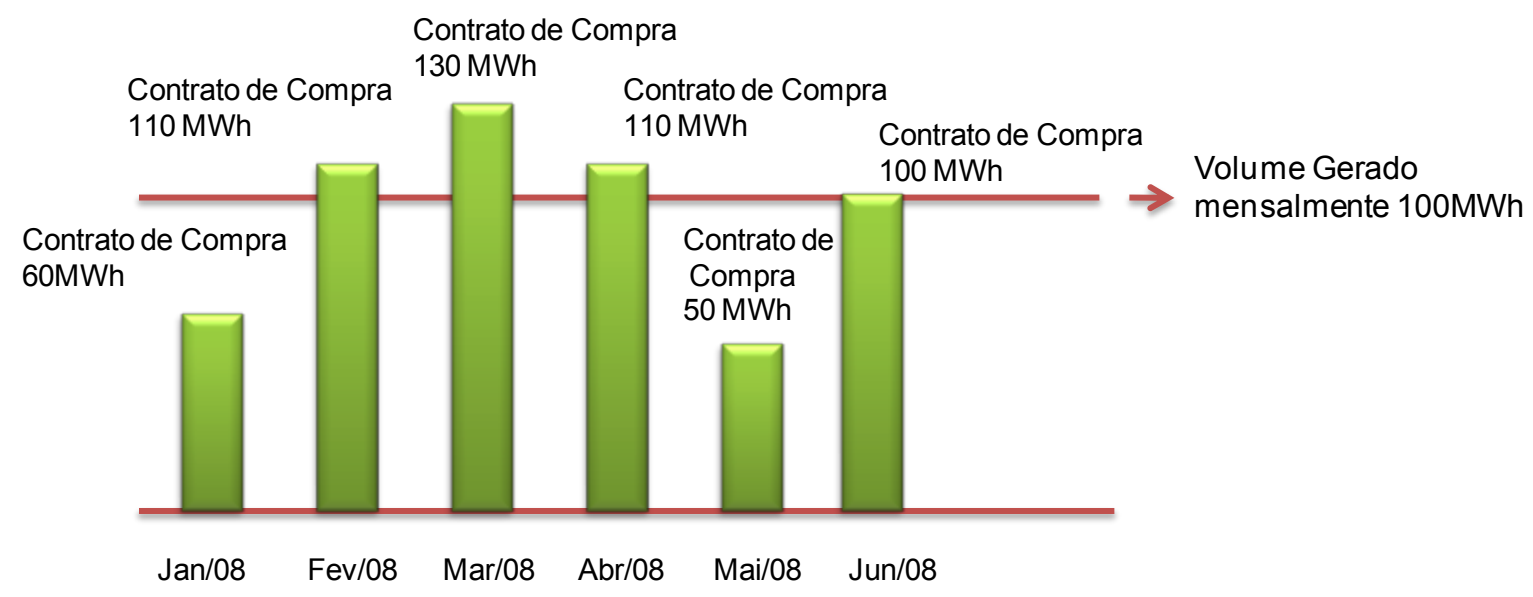

Figura 18: Exemplo de perfil de um gerador para apuração de penalidade por Insuficiência de Cobertura Contratual de Consumo.

Fonte: Elaboração própria utilizando os conceitos das Regras de Comercialização de Energia da CCEE - Módulo Penalidades.

A tabela 7, a seguir apresenta um exemplo númerico simplificado a partir da figura anterior dos cálculos de apuração das penalidades:

\begin{tabular}{|c|c|c|c|c|}
\hline \multicolumn{5}{|c|}{ Exemplo de apuração da Penalidade para o Gerador ou Comercializador Incentivado } \\
\hline $\begin{array}{l}\text { Apuração da Penalidade - } \\
\text { Mês da Contabilização }\end{array}$ & $\begin{array}{l}\text { Contrato de Venda } \\
\text { (MWh) }\end{array}$ & $\begin{array}{l}\text { Geração Mensal } \\
\text { (MWh) }\end{array}$ & $\begin{array}{l}\text { Contrato de Compra } \\
\text { (MWh) }\end{array}$ & $\begin{array}{l}\text { Nivel de } \\
\text { Insuficiência (MWh) }\end{array}$ \\
\hline jan/08 & $\begin{array}{l}\text { sem histórico anterior } \\
\text { ( ano 2007) }\end{array}$ & $\begin{array}{l}\text { sem histórico anterior } \\
\text { (ano 2007) }\end{array}$ & $\begin{array}{l}\text { sem histórico anterior } \\
\text { (ano 2007) }\end{array}$ & - \\
\hline fev/08 & $60($ jan/08) & $100($ jan/08) & 10 (jan/08) & 30 (sobra) \\
\hline $\mathrm{mar} / 08$ & $\begin{array}{l}60(\mathrm{jan} / 08)+ \\
110(\mathrm{fev} / 08)= \\
170\end{array}$ & $\begin{array}{l}100(\mathrm{jan} / 08)+ \\
100(\mathrm{fev} / 08)= \\
200\end{array}$ & - & $170-200=30$ (sobra) \\
\hline $\mathrm{abr} / 08$ & $\begin{array}{l}60(\mathrm{jan} / 08)+ \\
110(\mathrm{fev} / 08)+ \\
130(\mathrm{mar} / 08)= \\
300\end{array}$ & $\begin{array}{l}100(\mathrm{jan} / 08)+ \\
100(\mathrm{fev} / 08)+ \\
100(\mathrm{mar} / 08)= \\
300\end{array}$ & - & $300-300=0$ \\
\hline mai/08 & $\begin{array}{l}60(\mathrm{jan} / 08)+ \\
110(\mathrm{fev} / 08)+ \\
130(\mathrm{mar} / 08)+ \\
110(\mathrm{abr} / 08)= \\
410\end{array}$ & $\begin{array}{l}100(\mathrm{jan} / 08)+ \\
100(\mathrm{fev} / 08)+ \\
100(\mathrm{mar} / 08)+ \\
100(\mathrm{abr} / 08)= \\
400\end{array}$ & - & $410-400=10$ (déficit) \\
\hline
\end{tabular}

Tabela 7: Dados numéricos do gerador para demonstração do cálculo de apuração de penalidade por Insuficiência de Cobertura Contratual de Consumo.

Fonte: Elaboração própria utilizando os conceitos das Regras de Comercialização de Energia da CCEE - Módulo Penalidades.

O Preço de Referência para o cálculo do valor da Penalidade é o maior entre o Preço Médio da Liquidação das Diferenças e o Valor de Referência. Em continuação à figura 18 e tabela 7, apresenta-se a seguir a forma de cálculo do valor da penalidade: 


\begin{tabular}{|c|c|c|}
\hline \multicolumn{3}{|c|}{ Exemplo do cálculo do Valor da Penalidade } \\
\hline $\begin{array}{l}\text { Apuração da Penalidade - } \\
\text { Mês da Contabilização }\end{array}$ & $\begin{array}{l}\text { Nível de } \\
\text { Ins uficiência } \\
\text { (MWh) }\end{array}$ & $\begin{array}{l}\text { Valor da Penalidade } \\
\text { (R\$) }\end{array}$ \\
\hline $\mathrm{jan} / 08$ & - & - \\
\hline $\mathrm{fev} / 08$ & 30 (sobra) & - \\
\hline $\operatorname{mar} / 08$ & 30 (sobra) & - \\
\hline$a b r / 08$ & 0 & - \\
\hline mai/08 & 10 (déficit) & $10 * 139,44=1.234,40$ \\
\hline \multicolumn{3}{|l|}{ Exemplo: } \\
\hline \multicolumn{3}{|c|}{ Sendo o valor do VR $(2008)=139,44(R \$)$} \\
\hline \multicolumn{3}{|c|}{ Preço Médio da Liquidação das Diferenças = 120,00 (R\$) } \\
\hline \multicolumn{3}{|c|}{$\begin{array}{l}\text { Preço de Referência = maior valor entre o VR e Preço Médio da Liquidação das } \\
\text { Diferenças }=139,44(\mathrm{R} \$)\end{array}$} \\
\hline
\end{tabular}

Tabela 8: Dados numéricos do gerador para demonstração do cálculo do valor da penalidade por Insuficiência de Cobertura Contratual de Consumo.

Fonte: Elaboração própria utilizando os conceitos das Regras de Comercialização de Energia da CCEE - Módulo Penalidades.

\subsection{Venda de Excedentes pelos Consumidores Livres (Especiais)}

O Ministério de Minas e Energia disponibilizou para consulta pública (Portaria $\boldsymbol{n}^{\circ}$ 73/2010), a proposta de diretrizes para regulamentar a cessão de excedentes contratuais por consumidores livre e especial.

De acordo com a referida portaria, os consumidores livre e especial poderão ceder montantes de energia elétrica e de potência que sejam objeto de contrato validado na CCEE. Em suma, os montantes de energia elétrica passíveis de cessão pelos consumidores livres e especiais deveriam respeitar os seguintes limites:

(i) para o contrato celebrado e registrado na CCEE até cinco anos contados da data do ato de outorga de concessão para a implantação do empreendimento que proporciona a garantia física que constitui o respectivo lastro para venda, o limite de cessão é o montante contratado;

(ii) para o contrato celebrado e registrado na CCEE até três anos contados da data do ato de outorga de autorização para implantação do empreendimento que proporciona a garantia física que constitui o respectivo lastro para venda, o limite de cessão é o montante contratado; 
Já para os demais contratos:

a) contrato celebrado e registrado na CCEE com duração inferior a dois anos, o limite de cessão é de dez por cento do montante contratado;

b) contrato celebrado e registrado na CCEE com duração igual ou superior a dois anos e inferior a cinco anos, o limite de cessão é de vinte por cento do montante contratado;

c) contrato celebrado e registrado na CCEE com duração igual ou superior a cinco anos e inferior a dez anos, o limite de cessão é de cinquenta por cento do montante contratado; e

d) contrato celebrado e registrado na CCEE com duração igual ou superior a dez anos, o limite de cessão é o montante contratado.

Além disso, a partir de 2011, os registros de contratos na CCEE deveriam ser efetuados antes do início do respectivo período de consumo, conforme disciplina a ser estabelecida pela ANEEL, podendo ser admitido o registro de contrato após o mês de operação ou de consumo até o limite de cinco por cento dos montantes registrados para o respectivo mês de operação.

Outro ponto acrescentado foi autorizar a CCEE, conforme disciplina a ser estabelecida pela ANEEL, a promover Leilões de Excedentes do Mercado de Curto Prazo para atendimento ao Ambiente de Contratação Livre ( $A C L$ ), nos quais poderão ser negociadas eventuais sobras contratuais dos consumidores, sendo que tais leilões coexistirão com as negociações bilaterais.

Vale a pena acrescentar que o assunto trata de um antigo pleito do setor e que a esta audiência pública encontra-se ainda em análise do MME.

Ademais, também existe o Projeto de Lei tramitando sobre o assunto: Projeto de Lei $n^{\circ}$ 402/2009 que altera a Lei $n^{\circ}$ 9.427, de 26 de dezembro de 1996, para prever a livre comercialização de energia elétrica excedente por consumidores livres e especiais. 


\subsection{Penalidades por Alavancagem}

Foi realizada a Audiência Pública $n^{\circ}$ 123/2010, com período de contribuições de 23 de dezembro de 2010 a 04 de fevereiro de 2011, com objetivo de obter subsídios e informações adicionais para promover aprimoramentos em disposições relativas à apuração de insuficiência/cobertura contratual, e instituir a penalidade por violação de limite máximo de alavancagem.

A proposta é a adoção de metodologia que consiste em comparar a carga do sistema (média móvel de 12 meses para minimizar os efeitos da sazonalização) com a soma dos valores de garantia física de todas as usinas em operação comercial, expurgada a parcela de garantia física das usinas comprometidas com Contratos de Energia de Reserva (CER) [18].

Dessa comparação, surge o percentual de sobras de lastro (obtido pela razão entre as grandezas envolvidas no cálculo), a ser utilizado para identificar em qual dos quatro patamares estipulados se encontra a relação entre oferta e demanda de "lastro de energia". Por fim, para cada patamar, há um fator que multiplica o preço de referência da penalidade por insuficiência de lastro/cobertura contratual, que é o VR [18]. A figura 19, a seguir, apresenta a metodologia conforme descrito acima para obtenção do valor de penalidade por insuficiência de lastro/cobertura contratual.

Para que fosse implementado a metodologia apresentada na figura anterior, foram definidos os patamares de sobras de lastro de energia e os fatores de correção associados a esses patamares. Esses valores foram verificados por meio do histórico de valores de garantia física e carga obtido na CCEE que apresenta (i) os valores mensais de garantia física sazonalizada do período de janeiro de 2005 a junho de 2010; (ii) os valores mensais de carga do período de janeiro de 2005 a junho de 2010; e (iii) o Fator de Sobras de Lastro de Energia (FSLE) do período de janeiro de 2006 a junho de 2010 [18]. 
Preço da Penalidade $(\mathrm{R} \$ \mathrm{MWh})=F A T_{n} x V R$

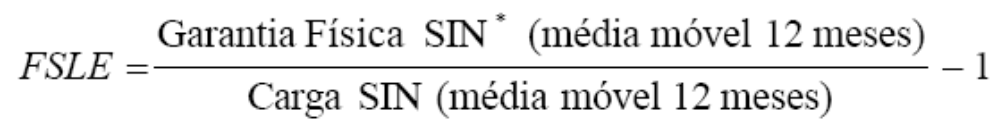

FSLE = Fator de Sobras de Lastro de Energia

* Expurgada a parcela de garantia física de usinas comprometidas com a contratação de energia de reserva

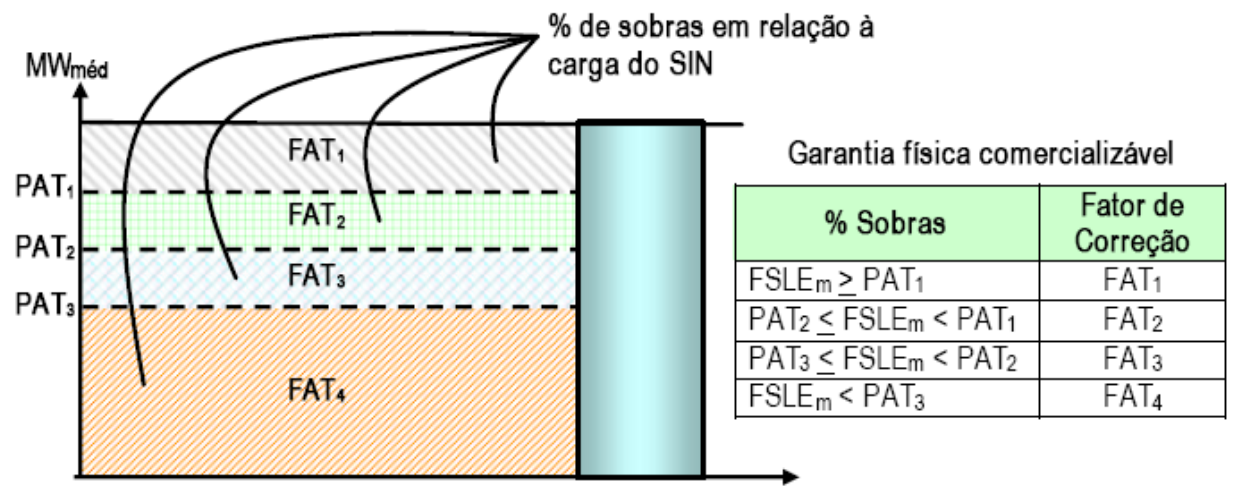

Figura 19: Obtenção do valor de penalidade por insuficiência de lastro/cobertura contratual. Fonte: Nota Técnica nº 123/2010-SEM/ANEEL [18].

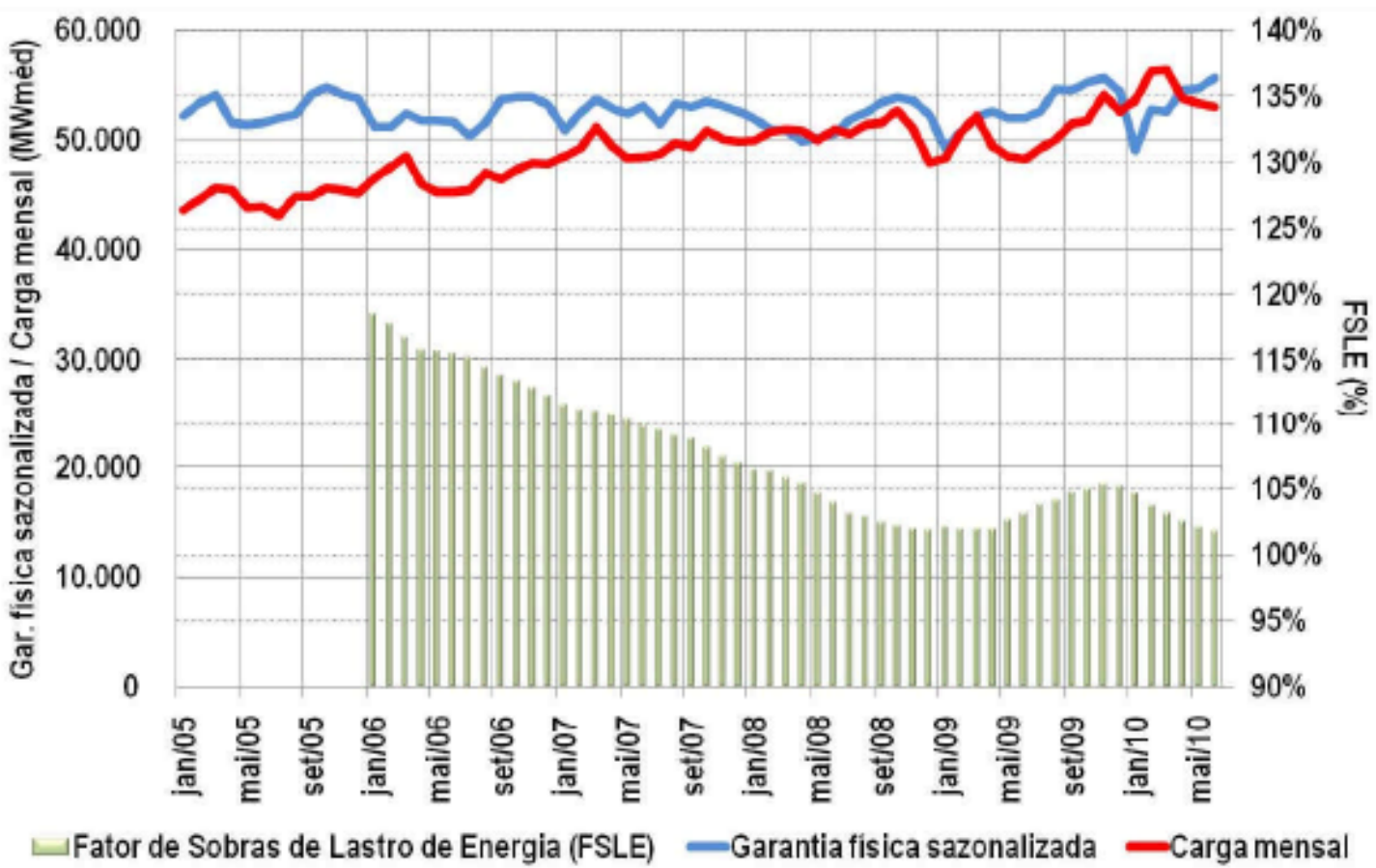

Figura 20: Comparação entre garantia física e carga do SIN.

Fonte: Nota Técnica n 123/2010-SEM/ANEEL [18]. 
Ao analisar os valores apresentados na figura 20 , em acordo com a Nota Técnica $\mathrm{n}^{\circ}$ 123/2010-SEM/ANEEL, a carga de alguns meses supera o valor da garantia física sazonalizada. Entretanto, utilizando a média desses valores em um período de 12 meses, percebe-se que sempre houve sobras de lastro, sendo que essas sobras variavam no intervalo de 2 a $18 \%$ da carga total do SIN verificada em períodos de 12 meses.

Assim, adotando a janela do ano civil (janeiro a dezembro), foi consolidado o Fator de Sobras de Energia (FSLE), conforme figura a seguir, que demonstra o parâmetro para os anos de 2005 a 2010, sendo que o valor referente para o ano de 2010 foi obtido dos valores de carga e garantia física sazonalizada somente dos meses de janeiro a junho, daí o valor negativo [18].

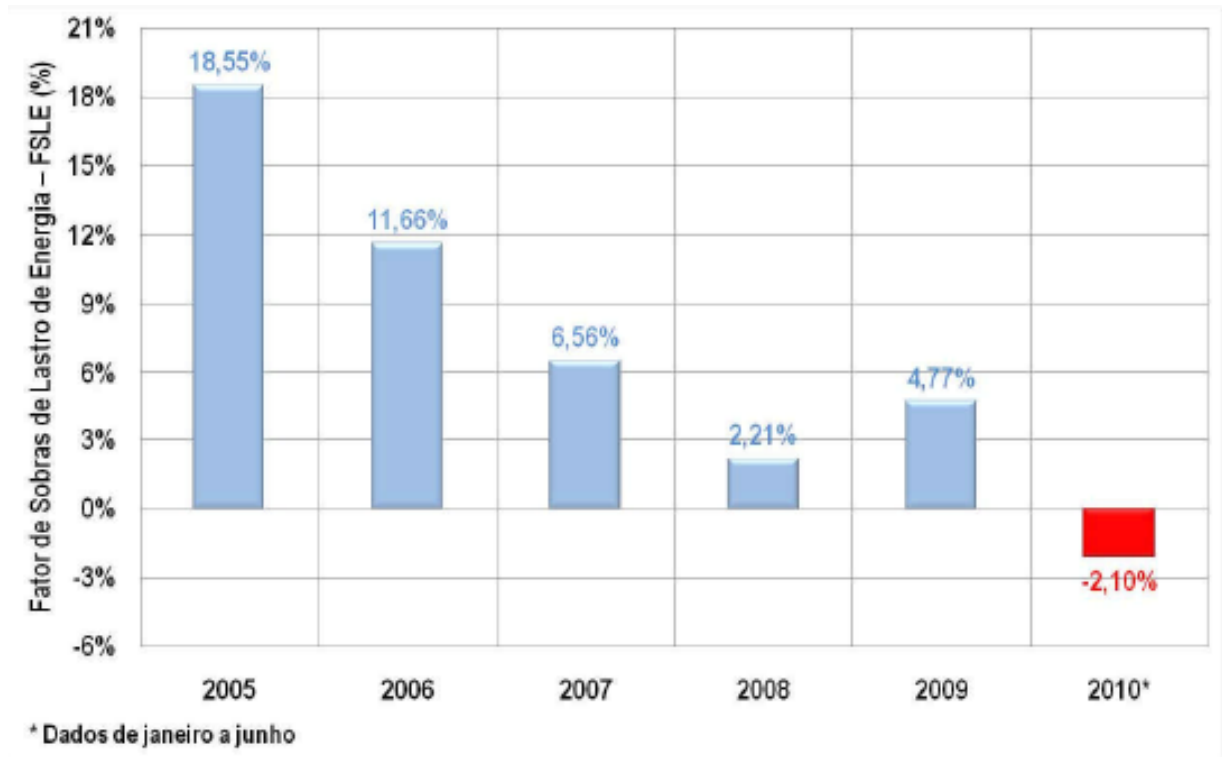

Figura 21: Valor do Fator de Sobras de Lastro de Energia (anos 2005 a 2010). Fonte: Nota Técnica n 123/2010-SEM/ANEEL [18].

De acordo com a Nota Técnica n 123/2010-SEM/ANEEL, considerando diversos aspectos, tais como: (i) o histórico de valores de garantia física e de carga; (ii) a representatividade dos ambientes de contratação regulada e livre; (iii) o incentivo à sobrecontratação por parte das distribuidoras; (iv) a impossibilidade de comercialização de sobras contratuais pelos consumidores livres/especiais; (v) a prática adotada por agentes de geração de "guardar" parte da garantia física para fins de hedge; (vi) o nível de atratividade do mercado spot; e (vii) os valores de ágio relativos aos contratos de curto prazo (ex-post) que são negociados pelas mesas de 
operação de agentes vendedores, bem como os sinais econômicos que devem advir da possibilidade de aplicação de penalidade por insuficiência de lastro/cobertura contratual, o entendimento foi de que devem ser adotados os patamares de sobras de lastro de energia e os fatores de correção, conforme figura a seguir:

\begin{tabular}{|l|c|c|}
\hline \multicolumn{1}{|c|}{$\%$ Sobras } & $\begin{array}{c}\text { Patamares de Sobras } \\
\text { de Lastro de Energia }\end{array}$ & $\begin{array}{c}\text { Fator de } \\
\text { Correção }\end{array}$ \\
\hline $\mathrm{FSLE}_{\mathrm{m}} \geq \mathrm{PAT}_{1}$ & $\mathrm{PAT}_{1}=10 \%$ & $\mathrm{FAT}_{1}=0,5$ \\
\cline { 1 - 1 } $\mathrm{PAT}_{2} \leq \mathrm{FSLE}_{\mathrm{m}}<\mathrm{PAT}_{1}$ & $\mathrm{PAT}_{2}=6 \%$ & $\mathrm{FAT}_{2}=0,7$ \\
$\mathrm{PAT}_{3} \leq \mathrm{FSLE}_{\mathrm{m}}<\mathrm{PAT}_{2}$ & $\mathrm{FAT}_{3}=0,8$ \\
\cline { 1 - 1 } $\mathrm{FSLE}_{\mathrm{m}}<\mathrm{PAT}_{3}$ & & $\mathrm{FAT}_{4}=1,0$ \\
& &
\end{tabular}

Figura 22: Parâmetros do valor da penalidade por insuficiência de lastro/cobertura contratual. Fonte: Nota Técnica n 123/2010-SEM/ANEEL [18].

O entendimento foi de que ao estabelecer uma correspondência entre o valor da penalidade e o impacto da insuficiência de lastro na questão da segurança de suprimento, a proposta apresentada permite que todos os agentes do mercado possam acompanhar, de modo transparente, as condições de equilíbrio entre oferta e demanda de energia elétrica, mediante divulgação mensal, pela CCEE, do chamado Fator de Sobras de Lastro de Energia.

O período de contribuições para esta audiência pública terminou em fevereiro de 2011 , entretanto até a presente data não foi divulgado o resultado de análise pela ANEEL.

\subsection{Liquidação Financeira}

Em conformidade com a Convenção de Comercialização de Energia Elétrica, a CCEE realiza o processo de liquidação financeira.

O processo de liquidação financeira consiste no pagamento e recebimento de todos os débitos e créditos referentes à compra e venda de energia elétrica no mercado de curto prazo que foram apurados no processo de contabilização. 
Para cada contabilização um determinado agente pode ficar em posição credora ou devedora. Assim, a somatória dos montantes a serem pagos pelos agentes devedores é igual à somatória dos montantes a serem recebidos pelos agentes credores.

$\mathrm{Na}$ data prevista no cronograma de liquidação financeira, todos os agentes devedores devem disponibilizar os montantes devidos em uma conta corrente específica junto ao Agente de Liquidação ${ }^{17}$. Em razão da impossibilidade de identificar contrapartes nas transações do mercado de curto prazo, caso algum agente fique inadimplente e suas garantias financeiras ${ }^{18}$ não sejam suficientes para liquidar todo o seu débito, é realizado um rateio desse saldo entre todos os agentes credores no processo ("loss sharing").

\subsection{Excedente Financeiro}

O intercâmbio de energia entre submercados, com preços diferentes, gera o excedente financeiro, devido ao fato de que a geração excedente no submercado exportador (preço mais baixo) será contabilizada ao PLD mais baixo, enquanto que o consumo excedente no submercado importador (preço mais alto) será contabilizado por um PLD mais elevado.

Assim, como os preços entre submercados são diferentes, ocorre o excedente financeiro, que corresponde à quantia equivalente ao intercâmbio de energia valorada pela diferença de preço entre os submercados. Como todos os agentes da CCEE pagaram e receberam os respectivos preços de seus submercados, o excedente financeiro não é vinculado a nenhum desses agentes.

Em um submercado tipicamente importador, como no caso do sudeste, é natural a existência de contratos que tenham fontes de geração localizadas em outros submercados. Como os contratos são registrados no submercado escolhido pelo comprador, um contrato onde o comprador está fisicamente localizado em um submercado importador poderá causar, ao vendedor, exposições à diferença de

\footnotetext{
17 Agente de Liquidação é a instituição financeira contratada pela CCEE para proceder a liquidação financeira das operações realizadas no mercado de curto prazo.

${ }^{18}$ Para efetuar o aporte de garantias e Liquidação Financeira, o Agente deve abrir conta corrente específica junto ao Agente Custodiante e Agente de Liquidação. Essa exigência é aplicável a todos os Agentes da CCEE, mesmo aos que já possuam conta junto à instituição financeira em questão.
} 
preços entre os submercados envolvidos. No submercado fonte, onde o vendedor tem suas usinas, porém não possui contrato, a energia será vendida ao PLD daquele submercado e no submercado destino, no qual o vendedor possui contrato de venda, mas não tem geração, o mesmo montante de energia será comprado no mercado de curto prazo, ao PLD desse submercado [16].

A seguir, ilustra-se um caso no qual um contrato pode estar sujeito ao risco da diferença do PLD entre os submercados:

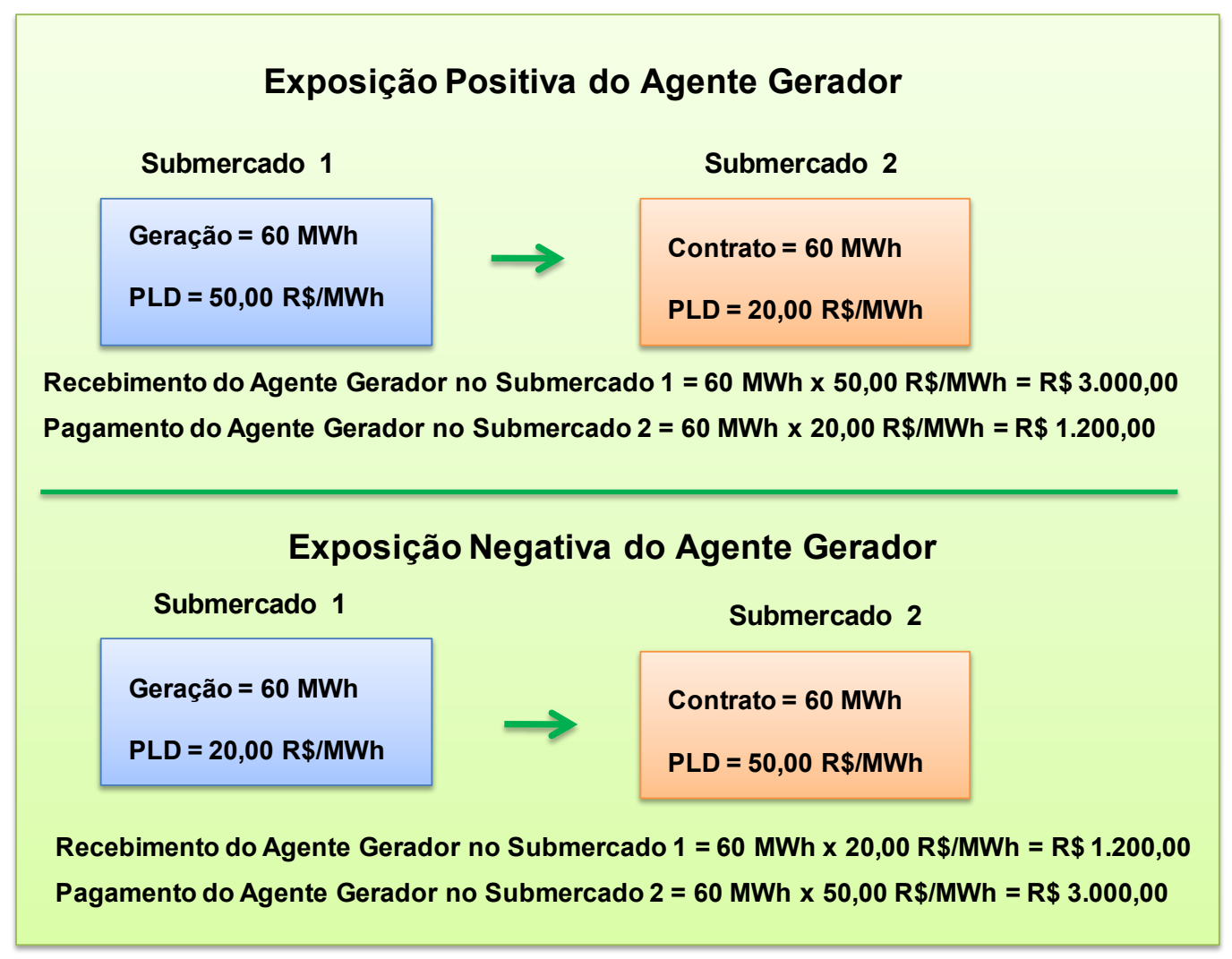

Figura 23: Exemplo de Exposição Positiva e Negativa de um contrato à diferença de preços de liquidação das diferenças entre submercados.

Fonte: CCEE - Câmara de Comercialização de Energia Elétrica. Visão Geral das Operações na CCEE. http://www.ccee.org.br [16].

Neste exemplo, o agente vendedor produz energia em um submercado para atender a um contrato que foi registrado no submercado do comprador. A exposição do contrato poderá ser positiva ou negativa, dependendo se o PLD do submercado onde a energia foi gerada for maior ou menor do que o PLD fixado para o submercado onde a energia foi comprada. 
Basicamente existem dois riscos que este mecanismo pode introduzir aos agentes. O primeiro é não dispor de recursos financeiros suficientes para abater as exposições negativas ou "prejuízos". O segundo é baseado na forma de tratar as exposições negativas não aliviadas, que são rateadas entre todos os geradores participantes do MRE proporcionalmente à Energia Assegurada. Portanto, mesmo que um Agente não tenha exposições negativas ou positivas pode ter que contribuir com este rateio [14].

Detalhando essa assertiva, vale salientar que o excedente financeiro é utilizado para aliviar as exposições negativas dos agentes de geração participantes do MRE que tiveram alocação de Energia Assegurada com preços diferentes daqueles em que estão localizadas suas usinas e também para os contratos: (i) PROINFA; (ii) contratos de Itaipú de quotistas no Submercado sul; (iii) Parcela de Contrato de importação da Argentina considerada nos Contratos Iniciais; (iv) Contratos de Autoprodução; (v) Direitos especiais (concedido às usinas específicas, definidas pela ANEEL através das Resoluções 211/01 e 431/01, com tratamento disciplinado pelo Despacho 288/02).

\subsection{Certificados de Energia Elétrica - Proposta de criação}

As associações do setor elétrico ( Abiape, Abraceel, Abrace, Anace, APMPE e Apine) estão propondo a criação de procedimentos de venda antecipada de energia no ACL, ou seja, os certificados de Energia. O objetivo principal da criação desses certificados é estimular a contratação de lastro de longo prazo e a negociação em bolsas mercantis.

A proposta seria de que os Certificados de Energia sejam o resultado da pulverização de lastros das garantias físicas dos empreendimentos em valores padrão, a critério e na proporção especificada pelo investidor proprietário do empreendimento. Os CCE's teriam sua emissão e comercialização controlada por regras proposta pelo mercado do setor elétrico e financeiro [17].

A abrangência da aplicação do CEE seria objeto de um critério de mercado, dado que a sua solicitação de emissão deve ser uma decisão do proprietário do ativo de geração, ou similar. 
A visão do CEE é sempre da energia futura; desta forma, todos os agentes geradores estariam aptos a solicitar a emissão do CEE do seu lastro futuro, dentro dos limites da garantia física futura do seu empreendimento, na proporção que desejarem. O comprometimento comercial dos CEE em operações já realizadas, como venda de contratos bilaterais ou CCEAR's e parcelas de autoprodução, ficaria a cargo de o emissor identificar, permitir e dar ciência ao mercado [17].

Os CEE's poderão estar também submetidos ao ACR por circunstâncias operacionais de lastros contratuais, por se tratar de garantia física de ativos de geração, sendo neste caso, apenas para fins de monitoramento.

$\mathrm{Na}$ visão processual os CEE's representariam um pequeno contrato de compra e venda de energia elétrica, em um padrão comercial acordado pelo mercado. O título seria um ativo financeiro, ou seja, não implicaria no compromisso de entrega física da energia elétrica, assim como os contratos bilaterais. No entanto, possui responsabilidade contratual e representam um direito de crédito ao portador, ou seja, o direito de registro do montante de energia especificado no certificado, para fins de contabilização e liquidação no ambiente da CCEE.

A figura a seguir apresenta como proposta das associações a visão geral, no qual os CEE's se inserem como instrumento de comercialização:

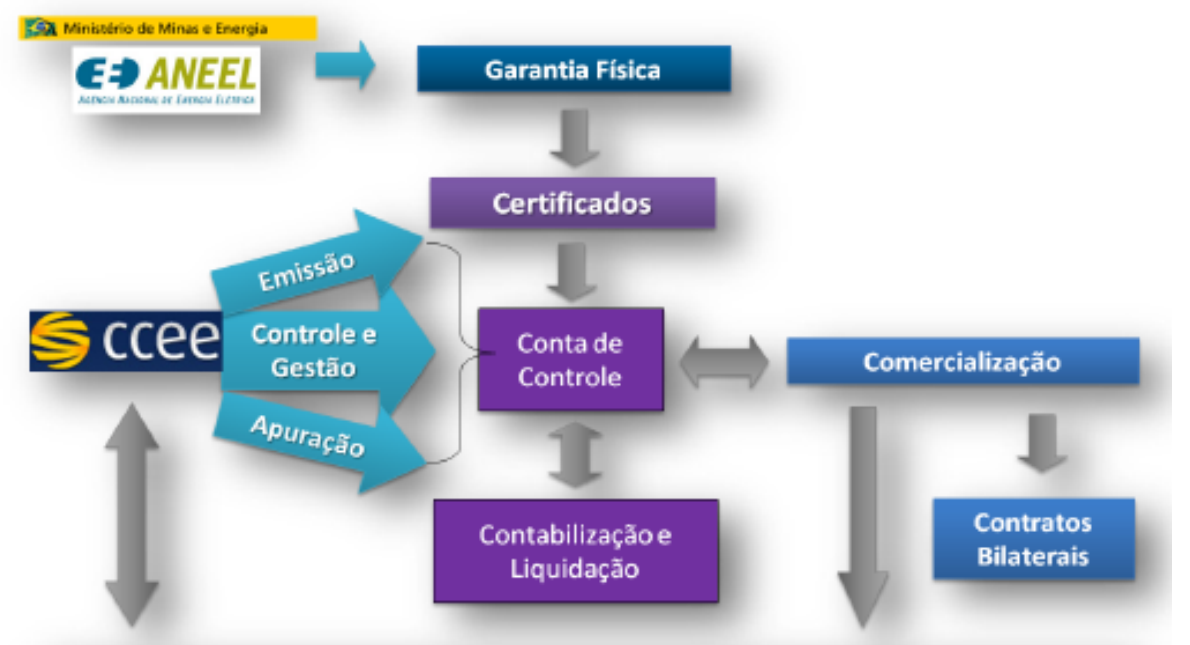

Bolsa - Ambiente Controlado de Negociação de Certificados

Figura 24: Visão Geral do Processo do CEE (Sugestão).

Fonte: O Desenvolvimento do ACL - Questões e Soluções [17]. 


\subsection{Programa de Incentivo às Fontes Alternativas - PROINFA}

\subsubsection{Caracterização do Programa}

O Programa de Incentivo às Fontes Alternativas de Energia Elétrica (PROINFA) foi criado no âmbito do Ministério de Minas e Energia (MME), pela Lei $n^{\circ}$ 10.438/2002.

O objetivo do PROINFA foi aumentar a participação da energia elétrica produzida por empreendimentos de Produtores Independentes Autônomos, concebidos com base em fontes eólica, pequenas centrais hidrelétricas ( $\mathrm{PCH}$ 's) e biomassa, no Sistema Elétrico Internacional Interligado (SIN).

Nesse contexto, o PROINFA inaugurou uma nova estratégia para a inserção sustentável das energias alternativas renováveis na matriz energética brasileira, reforçando a diversificação da matriz e o estímulo ao desenvolvimento de fontes renováveis.

O PROINFA foi dividido em 2 etapas. Na primeira etapa destaca-se a previsão de implantação de 3.300 (três mil e trezentos) MW de capacidade em instalações de produção com início de funcionamento previsto para até dezembro de 2008. A contratação dessa energia deveria ser distribuída igualmente para cada fonte participante do PROINFA (eólicas, PCHs e biomassa), ou seja, 1.100 (mil e cem) MW para cada fonte.

A energia produzida pelos empreendimentos do programa deveria ser adquirida pela Centrais Elétricas Brasileiras S.A. (Eletrobras) e os contratos dos geradores com a Eletrobrás teriam o prazo de 20 (vinte anos), contados a partir de sua entrada em operação. Os contratos de compra e venda da energia do PROINFA são compulsórios a todas as cargas do SIN, sendo representados pela CCEE e remunerados via Tarifa de Uso do Sistema de Distribuição e/ou Transmissão.

Ressalte-se ainda que, a aquisição da energia no PROINFA seria efetivada pelo valor econômico correspondente à tecnologia específica de cada fonte, a ser definido pelo Poder Executivo. 
Destaca-se nesse programa, a produção de energia eólica, que obteve um grande avanço na matriz energética brasileira. O PROINFA foi uma grande experiência para esse tipo de geração de energia, possibilitando testar todas as dificuldades da implementação de um novo sistema, sejam estas de natureza ambiental, concernentes à conexão, de estabilidade da rede, ou ainda de avaliação de tecnologia empregada.

Um ponto importante é que as primeiras usinas serviram para mostrar que vários estados possuem potencial eólico, bem como possibilitar ao Operador Nacional do Sistema Elétrico (ONS), análise do comportamento da eólica, inseridos na rede.

A garantia de venda de energia proporcionada pelo PROINFA garantiu financiamento pelo BNDES para as $\mathrm{PCH}$ 's, apesar de já possuírem participação na matriz energética brasileira antes da implantação do programa.

Por outro lado, a contratação de biomassa apresentou-se abaixo das expectativas em razão dos preços não atrativos estipulados pelo MME.

A regulamentação do PROINFA, prevendo contratação compulsória da energia e com valores de referência de custo "confortáveis", fixados pela Eletrobrás, conduziu à obtenção de preços muito elevados para a energia adquirida dos empreendimentos enquadrados, fato esse agravado pela ausência de incentivos para a redução de custos por parte dos empreendedores.

Não obstante, além de contemplar facilidades na contramão do interesse do consumidor, o PROINFA enfrentou sérios problemas de implementação e foram registrados inúmeros atrasos nas datas previstas para entrada em operação das instalações.

Registre-se ademais, em acordo com o Decreto $n^{\circ} \mathbf{5 . 0 2 5 / 2 0 0 4}$, que o PROINFA visa reduzir a emissão de gases de efeito estufa, nos termos da Convenção-Quadro das Nações Unidas sobre a Mudança do Clima, contribuindo para o desenvolvimento sustentável. 
De acordo com o Plano Nacional de Mudanças Climáticas, quanto às emissões de gases de efeito estufa, pode-se ressaltar que, com a implantação do PROINFA, estima-se uma redução anual de 3 milhões de toneladas de CO2.

Importante acrescentar que o PROINFA é considerado adicional no âmbito do Mecanismo de Desenvolvimento Limpo (MDL) e que os benefícios financeiros advindos da comercialização dos créditos de carbono gerados pelos projetos serão revertidos para o consumidor final, reduzindo os encargos do PROINFA e contribuindo para a modicidade tarifária. Entretanto, cabe salientar que o PROINFA nada fez até agora para contabilização e verificação da redução das emissões.

A Lei $n^{\circ} \mathbf{1 2 . 4 3 1 / 2 0 1 1}$, derivada da MP 517 prorroga a validade do PROINFA até 30 de dezembro de 2011.

\subsubsection{Contratos do PROINFA}

Compete à ANEEL, a regulamentação dos procedimentos para o rateio dos custos e da energia elétrica do Programa de Incentivo às Fontes Alternativas de Energia Elétrica - PROINFA, levando em consideração o respectivo Plano Anual (PAP) elaborado pela Eletrobrás (Centrais Elétricas Brasileiras S/A).

As quotas de custeio do PROINFA são estabelecidas em conformidade com o Plano anual do PROINFA que é elaborado pelo PROINFA (artigo $\mathrm{n}^{\circ} 12$ do Decreto no

\section{$5.025 / 2004)$}

Assim, os contratos do PROINFA representam os efeitos da energia comercializada pela Eletrobrás na CCEE, da energia elétrica produzida pelas usinas participantes do PROINFA com as distribuidoras de energia e consumidores livres, adquirentes da quota de energia.

Para efeitos de contabilização e liquidação na CCEE, é necessária a modulação desses contratos, de cada cotista do PROINFA, servindo de lastro de energia para os adquirentes dessas quotas.

A figura 25, a seguir, representa a energia comercializada na CCEE por meio das quotas do PROINFA para um consumidor: 
Figura 25: Representação da energia comercializada pela Eletrobrás na CCEE.

Fonte: Elaboração própria utilizando os conceitos das Regras e Procedimentos de Comercialização de Energia [5].

\subsection{LEILÕES DE ENERGIA}

Conforme já dito inicialmente no capítulo 2.7.3, os leilões de energia estabelecem o valor adequado ao equilíbrio do preço com a percepção do risco, porém de forma a estabelecer um preço teto coerente com a prática da modicidade tarifária.

Assim, os Contratos de Comercialização de Energia no Ambiente Regulado (CCEAR's) são resultado da comercialização de energia no Ambiente de Contratação Regulado (ACR), no qual as distribuidoras adquirem energia para atendimento à sua carga.

\subsubsection{Contratos de Comercialização de Energia no Ambiente Regulado (CCEAR's)}

Conforme o disposto no Art. 28 do Decreto $n^{\circ} 5.163 / 2004$, o CCEAR poderá ter as seguintes modalidades: (i) Quantidade de Energia Elétrica; ou (ii) Disponibilidade de Energia Elétrica.

Os CCEARs na modalidade Quantidade de Energia são os contratos em que o vendedor é responsável pela entrega da quantidade de energia contratada no centro 
de gravidade do submercado do empreendimento de geração, assumindo os custos decorrentes do risco hidrológico. Já os riscos financeiros decorrentes de diferença de preços entre os submercados da entrega e do consumo são assumidos pelo comprador [21].

A contratatação por quantidade de energia vem sendo empregada para a comercialização da maior parte do volume disponível de energia existente e também da energia de novos empreendimentos hidrelétricos, com os riscos hidrológicos mitigados pelo Mecanismo de Realocação de Energia [12].

Os CCEARs na modalidade Disponibilidade de Energia são contratos de energia proveniente de empreendimentos termelétricos, cujos riscos, ônus e benefícios da variação da produção em relação à garantia física são alocados ao grupo de distribuidoras participantes do leilão que, posteriormente, repassam para os consumidores regulados por meio das tarifas de energia elétrica [21].

A contratação por disponibilidade vem sendo empregada para a comercialização de energia de novos empreendimentos termelétricos convencionais (combustíveis fósseis), cujo custo variável de produção e a incerteza sobre o despacho são elevados [12].

\subsubsection{Leilões de Energia de Reserva}

A contratação de energia de reserva é regulamentada pelo Decreto $n^{\circ}$ 6.353/2008. Entende-se por energia de reserva aquela destinada a aumentar a segurança no fornecimento de energia elétrica ao sistema Interligado Nacional (SIN).

Decreto $n^{\circ}$ 6.353/2008 estabelece que a Energia de reserva seja contratada mediante leilões a serem promovidos pela ANEEL, direta ou indiretamente, conforme diretrizes do MME.

Referido Decreto estabelece em seu artigo $n^{0} 1$ e $\S 2^{\circ}$, que serão objeto de contratação de energia de reserva: (i) a energia proveniente de novos empreendimentos de geração; e (ii) de empreendimentos existentes, desde que acrescentem garantia física ao SIN ou sejam empreendimentos que não entraram em operação comercial, até a data de publicação desse Decreto. 
Importante ressaltar que, após adquirida nos leilões, a energia de reserva não pode constituir lastro para revenda de energia e que a mesma será contabilizada e liquidada exclusivamente no Mercado de curto Prazo (MCP) da CCEE.

\subsubsection{Contratação de Energia de Reserva}

De acordo com o Art $n^{\circ} 2$ do Decreto $n^{\circ}$ 6353/2008, a contratação de energia de reserva é formalizada mediante a celebração de Contrato de Energia de Reserva (CER) entre os agentes vendedores nos leilões e a CCEE, como representante dos agentes de consumo, incluindo consumidores livres, aqueles referidos no $\S 5$ do Art.

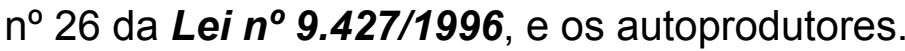

Assim, definida a CCEE como responsável pela celebração dos Contratos de Energia de Reserva (CER) na condição de representante dos agentes de consumo, com os agentes vendedores nos Leilões de Energia de Reserva, é necessária a realização de toda a operacionalização destes contratos por parte da CCEE.

Ressalte-se ainda a Energia de Reserva poderá ser contratada nas modalidades por quantidade ou por disponibilidade, observado o disposto no Art. 28 do Decreto $\boldsymbol{n}^{\circ}$ $5.163 / 2004$.

Em acordo com o Art. $3^{a}$ da Lei $n^{0}$ 10.848/2004, os custos decorrentes da contratação de energia de reserva, dentre outros custos administrativos, financeiros e encargos tributários, serão rateados entre todos os usuários finais de energia elétrica do SIN, incluindo os consumidores referidos nos Art. 15 e 16 da Lei $n^{\circ}$ 9.074/1995 e no $§ 5$ do Art. 26 da Lei $n^{\circ}$ 9.427/1996 e os autoprodutores apenas na parcela da energia decorrente da interligação ao SIN. Esses custos são pagos aos geradores mensalmente no âmbito da liquidação financeira específica a ser realizada pela CCEE, por intermédio de Encargos de Energia de Reserva (EER).

Dessa forma, uma vez que a CCEE participa, de forma ativa, da estrutura formada para implementação e operacionalização da contratação de Energia de Reserva, uma parcela dos recursos financeiros obtidos com o recolhimento do Encargo de Energia de Reserva (EER), é destinada para cobertura dos custos de natureza administrativa, financeira e tributária incorridos pela CCEE nesse processo [20]. 
Com o propósito de disciplinar a relação entre a CCEE e o Usuário de Energia de Reserva e, consequentemente, consolidar o arranjo comercial associado à contratação de Energia de Reserva, a CCEE celebra, com cada Usuário de Energia de Reserva ${ }^{19}$ o Contrato de Uso da Energia de Reserva (CONUER), cujo modelo foi aprovado pela ANEEL e consta do Anexo da Resolução Normativa $n^{\circ}$ 337/2008 [20].

Todos os agentes de distribuição e consumidores livres, inclusive aqueles previstos no $\S 5$ do Art. $n^{\circ} 26$ da Lei $n^{\circ}$ 9427/1996, bem como os autoprodutores, deverão firmar Contrato de Uso da Energia de Reserva (CONUER) com a CCEE e aportar a garantia financeira correspondente.

Os recursos administrativos envolvidos na Contratação de Energia de Reserva são administrados pela CCEE, mediante gestão da Conta de Energia de Reserva (CONER), e todos esses valores monetários integram o processo de Liquidação Financeira relativa à Contratação de Energia de Reserva. A CCEE é parte do CER, sendo também responsável pelo lançamento, na referida liquidação financeira, dos valores monetários devidos aos Agentes Vendedores de Energia de Reserva.

A figura 26, a seguir, representa os dispositivos contratuais e financeiros decorrentes da contratação de Energia de Reserva:

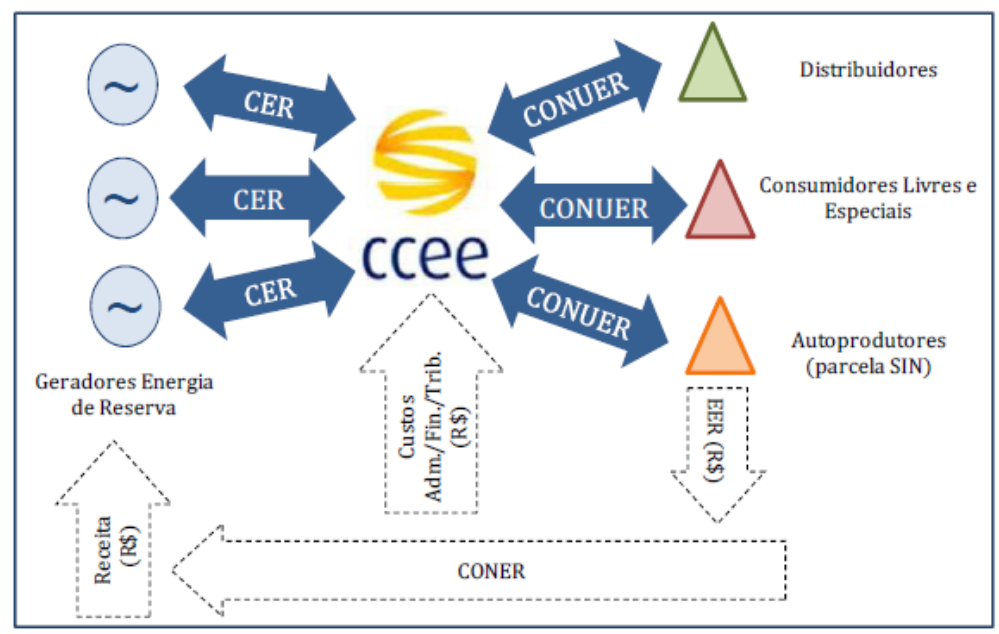

Figura 26: Contratos e Fluxo financeiro decorrentes da contratação de Energia de Reserva. Fonte: Regras de Comercialização aplicáveis ao Novo Sistema de Contabilização e Liquidação Novo SCL [20].

\footnotetext{
${ }^{19}$ Usuário de Energia de Reserva é um agente de distribuição, consumidor livre, consumidor especial, autoprodutor na parcela da energia adquirida, agente de geração com perfil de consumo ou agente de exportação que seja agente da CCEE (Resolução Normativa $n^{\circ} 337 / 2008$ )
} 
Assim, conforme dito, a CCEE mantém a Conta de Energia de Reserva (CONER), observando as seguintes finalidades e diretrizes: (i) receber o EER; (ii) efetuar os pagamentos devidos aos agentes vendedores, nos termos do CER; (iii) receber os valores pagos a título de penalidades relativas à Energia de Reserva; (iv) receber os valores relativo à inadimplência no pagamento do EER; (iv) receber os valores da Energia de Reserva liquidados no Mercado de curto Prazo, nos termos do $\S 1$ do Art. $n^{\circ} 4$ do Decreto $n^{\circ} 6353 / 2008$; e (vi) ressarcir os custos de estruturação e de gestão dos contratos e da Conta de que trata o Decreto.

Uma parcela do saldo da CONER será destinada à constituição de fundo de garantia para o pagamento devido aos agentes vendedores que firmaram o CER, com o objetivo de mitigação de eventual inadimplência no recolhimento do EER.

Cabe acrescentar ainda, a título de esclarecimento, que a Resolução Normativa $n^{\circ}$ 337/2008 estabelece as disposições relativas à contratação de energia de reserva e aprova o modelo do Contrato de Uso da Energia de Reserva - CONUER.

Diante do exposto, vale a pena complementar ainda que, nos meses em que há geração nas usinas comprometidas com CER, observado o período de entrega da energia contratada, a energia produzida é liquidada no Mercado de Curto Prazo (MCP), sendo a receita auferida com essa liquidação repassada a um agente virtual, - Agente associado à Contratação de Energia de Reserva (ACER), para posteriormente ser destinada à Conta de Energia de Reserva (CONER) para fins de composição dos recursos financeiros necessários para cobertura dos custos decorrentes da contratação de energia de reserva [20].

Ainda, com relação ao rateio dos custos decorrentes da contratação de Energia de Reserva, a parcela devida individualmente pelos Usuários de Energia de Reserva é estabelecida em base anual, de acordo com os dados de medição registrados na CCEE para efeito de contabilização no Mercado de Curto Prazo (MCP) nos últimos doze meses, sendo considerado, nesse rateio, os montantes de geração provenientes dos empreendimentos de autoprodução e produção independente destinados ao atendimento de unidades de consumo correlatas [20]. 
Nos Contratos de Energia de Reserva (CER) são estabelecidas penalidades a serem apuradas caso o agente vendedor de Energia de Reserva não cumpra com as suas obrigações, sendo essas penalidades, abatidas diretamente do pagamento devido ao agente, em acordo com as Regras e Procedimentos de Comercialização.

A figura 27, a seguir, repesenta o fluxo dos recursos financeiros da CONER:

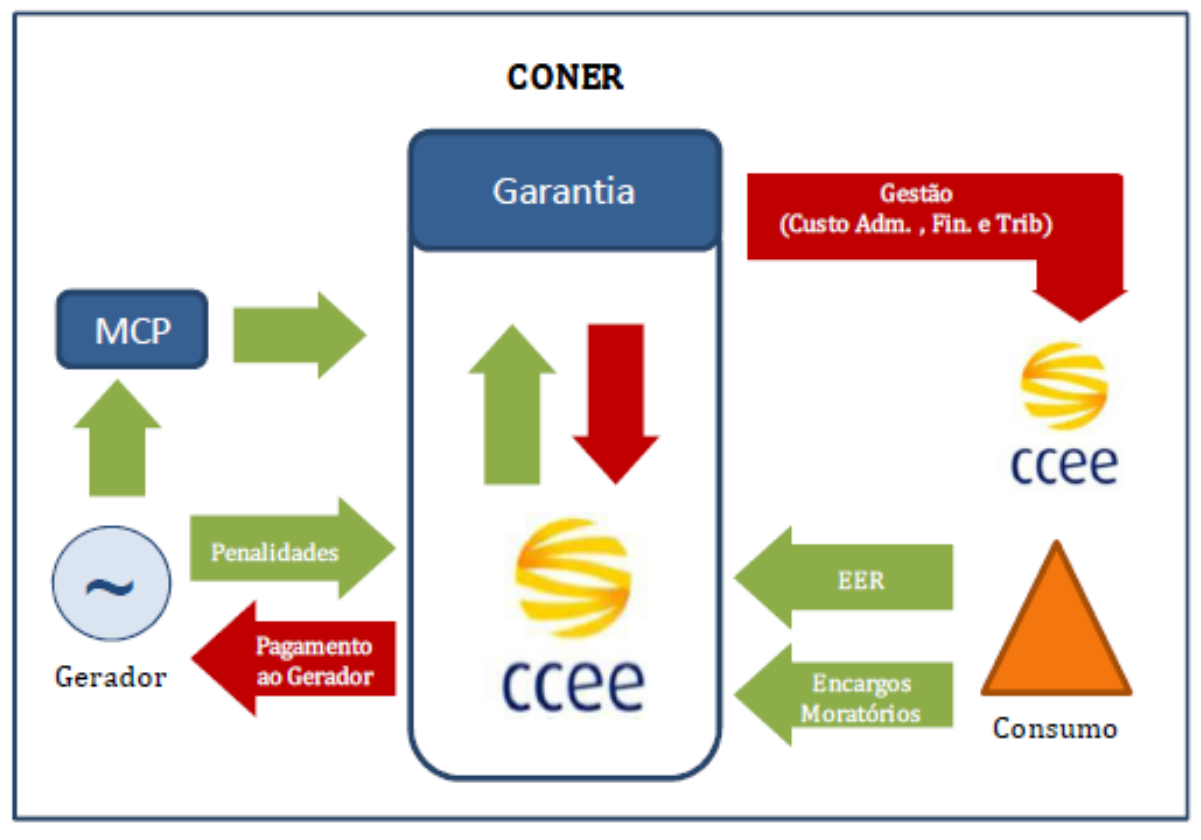

Figura 27: Fluxo de recursos financeiros da CONER.

Fonte: Regras de Comercialização aplicáveis ao Novo Sistema de Contabilização e Liquidação Novo SCL [20].

Com relação à figura acima, cabe esclarecer que os eventuais encargos moratórios previstos como créditos da CONER se referem à cobrança de multa e juros dos Usuários de Energia de Reserva inadimplentes no recolhimento do EER [20].

\subsubsection{Contabilização do Contrato de Energia de Reserva (CER)}

Para efeito de contabilização e liquidação de diferenças entre o montante de energia contratado e a produção efetiva, o prazo do contrato é subdividido em 5 períodos de conciliação quadrienais. A produção anual média é comparada com o valor anual contratado, obtendo-se o saldo anual de cada ano [12].

Com base no saldo anual, tem-se as seguinte encontro de contas, anualmente, dentro do quadriênio [40]: 
- Se o saldo anual for inferior a 90\% da obrigação contratual, o vendedor de energia deve ressarcir à CCEE o montante de energia não entregue, até o limite inferior, no preço do contrato acrescido de 15\%, em 12 parcelas;

- Se o saldo anual for superior a $130 \%$ da obrigação contratual, o vendedor de energia receberá da CCEE o montante de energia entregue, até o limite superior, a $70 \%$ do preço do contrato, em 12 parcelas;

- Se o saldo anual estiver entre $90 \%$ e $130 \%$ da obrigação contratual, não haverá encontro de contas, e o saldo é carregado para o ano seguinte.

Ao final de cada quadriênio é realizado um encontro final de contas:

- Se o saldo for negativo, ou seja, inferior à obrigação contratual, o vendedor deverá ressarcir a energia não entregue à CCEE ao mesmo preço do contrato, em 12 parcelas;

- Se o saldo for positivo, o vendedor poderá: i) repassar o saldo para o quadriênio seguinte, como crédito de energia; ii) ceder para outros agentes de geração que comercializaram energia no mesmo leilão; iii) liquidar o saldo ao mesmo valor do contrato, em 24 parcelas;

No início de cada quadriênio, a partir do segundo, é realizada a reconciliação contratual, ou seja, a obrigação contratual do próximo quadriênio será a média da produção dos anos anteriores, desde o início do suprimento, limitado ao montante originalmente contratado.

Em resumo, a tolerância estabelecida dentro de uma banda, que fica entre $90 \%$ e $130 \%$ da quantidade contratada, permite a previsibilidade do fluxo de recursos por parte do investidor. O gerador, num ano em que houve pouco vento, poderá compensar a baixa geração de energia no ano seguinte, sem impacto na receita fixa, dentro de um quadriênio [40].

\subsubsection{Contratação de Energia Eólica}

O investimento privado na geração de energia eólica depende do retorno financeiro e está diretamente relacionado aos riscos de sua implementação. Sabe-se que este 
tipo de geração possui elevado investimento inicial, entretanto o seu custo operacional é muito baixo.

Em razão da aleatoriedade da geração de energia eólica, o acesso a financiamentos acaba por encarecer esta opção, pois o preço, a garantia de tempo de recuperação do capital e acesso aos financiamentos, são fatores que influenciam a expectativa de retorno. Assim, esse risco pode ser amenizado com a transferência de parte dos riscos a terceiros. [12]

Ainda, a contratação de energia eólica na modalidade de energia de reserva tem influência positiva na absorção destes riscos, uma vez que podem ser mitigados, por meio desse tipo de modalidade que considera a produção média ao longo dos anos.

As usinas eólicas têm a mesma característica operacional de hidrelétricas a fio d'água não despachadas centralizadamente, ou seja, sempre gerarão a energia correspondente ao vento que existir a cada instante, dentro dos limites operacionais das máquinas. Deste modo, as gerações destas usinas não estão sujeitas a riscos hidrológicos decorrentes do despacho centralizado do SIN [12].

A energia eólica de reserva é contratada na modalidade de "disponibilidade", mitigando os riscos elevados que assumiria se a contratação fosse pela modalidade "quantidade". Seja como for, existe a contabilização da energia produzida, consolidando um balanço anual, configurando-se a obrigação do agente produzir pelo menos a sua Garantia Física, que define a receita fixa a ser paga ao agente.

Ocorre que a integralização da Garantia Física declarada pode ocorrer em período de até 4 anos e, em não ocorrendo, o agente eólico deverá "devolver" os valores contratuais recebidos a maior, sem penalidade.

Nestes termos, a contratação de energia eólica na modalidade de um leilão de compra de Energia de Reserva (LER), com a integralização da produção eólica em base anual é a que se afigura mais adequada para uma contratação inicial [12]. 


\subsubsection{Contratação de Termelétricas a Biomassa}

A contratação por disponibilidade de energia foi empregada também para a contratação de termelétricas a biomassa, cujos custos variáveis de produção são considerados nulos ${ }^{20}$ e sem incerteza de despacho, mas que teriam risco elevado na comercialização por quantidade durante a entressafra, quando os empreendedores estariam expostos à volatilidade do preço de curto prazo se a energia contratada fosse nessa modalidade [12]. Ressalte-se que o despacho das termelétricas a biomassa segue a declaração de energia disponível feita pelo agente.

A contratação por disponibilidade da energia produzida pelas termelétricas movidas a biomassa, requer a produção efetiva declarada, sendo a produção efetiva acumulada ao longo dos períodos de contabilização da energia declarada. Assim, o risco de produção é mitigado pela estocagem de biomassa e pela acumulação de produção total ao longo do período de contabilização contratual.

\footnotetext{
${ }^{20} \mathrm{Em}$ alguns casos, como na maioria dos empreendimentos termelétricos a biomassa, o CVU tem valor 0 (zero). Assim, em caso de atraso para o início da operação comercial, qualquer que fosse o contrato de compra e venda celebrado pelo agente vendedor, o custo que seria repassado pelo consumidor final ao vendedor seria zero, visto que esse seria o menor valor verificado dentre as opções previstas nos incisos de I a IV da RN 165.
} 


\section{ENERGIA INCENTIVADA - UMA VISÃO SUSTENTÁVEL}

\subsection{Considerações Iniciais}

A tendência nítida de aumento sustentado das emissões de carbono, mesmo com a realização de vários projetos do Mecanismo de Desenvolvimento Limpo (MDL), é um fator preocupante. O estímulo à energia incentivada pode ser considerado relevante na redução dos níveis de emissões do setor elétrico.

O objetivo deste capítulo é discutir a representatividade e a importância da geração de energia a partir das fontes consideradas incentivadas na matriz energética brasileira, uma vez que, conforme já apresentado ao longo desse trabalho, diversos são os incentivos relacionados às fontes consideradas limpas.

O Brasil dispõe de diversas alternativas para a expansão da oferta de energia elétrica, livres de emissão ou com redução de carbono, adicionais à hidroeletricidade. Destaca-se a geração a partir de fontes renováveis, cogeração a partir do bagaço de cana de açúcar ou outras formas de biomassa, eólica e solar, bem como geração a partir de resíduos sólidos.

As usinas eólicas e as usinas térmicas a bagaço de cana de açúcar apresentam a possibilidade de gerar energia justamente no período de deplecionamento dos reservatórios do Sistema Interligado Nacional (SIN). O perfil de geração dessas usinas apresenta seu máximo justamente quando o sistema interligado necessita economizar água $\mathrm{e}$, tradicionalmente, são despachadas usinas térmicas a combustíveis fósseis. A complementaridade dessas fontes representa uma menor necessidade de usar água e/ ou acionar usinas térmicas, bem como proporcionam benefícios energéticos ao sistema e evitam a emissão de gases de efeito estufa [2].

Além disso, no caso da obtenção de energia, proveniente da biomassa vegetal, é importante ressaltar que o dióxido de carbono emitido na queima da biomassa é recapturado da atmosfera pela fotossíntese das plantas durante o seu cultivo. 
De acordo com a Resenha Energética Brasileira (Exercício de 2010), que realiza a análise de registros da configuração de dados de consumo, produção e comercialização de diferentes formas de energia em âmbito nacional, com relação à Oferta Interna de Energia Elétrica (OIEE), a geração eólica passou de 1.238 GWh em 2009 para 2.177 GHh em 2010, representando crescimento cerca de 76\%, enquanto a geração por biomassa cresceu $24 \%$, sendo que, o destaque fica pelo aumento da geração a bagaço de cana.

A tabela 09, a seguir, ilustra a Oferta Interna de Energia Elétrica (OIEE), referente ao ano de 2010 em comparação ao ano de 2009. Importante observar o forte crescimento da geração eólica, seguido da geração a biomassa.

\begin{tabular}{lrrrrrr}
\hline & \multicolumn{2}{c}{ GWh } & \multicolumn{2}{c}{ ESTRUTURA (\%) } \\
ESPECIFICAÇÃO & \multicolumn{2}{c}{$\mathbf{2 0 0 9}$} & $\mathbf{2 0 1 0}$ & $\mathbf{1 0} / \mathbf{0 9} \%$ & $\mathbf{2 0 0 9}$ & $\mathbf{2 0 1 0}$ \\
\hline HIDRO & 390.988 & 405.055 & 3,6 & 77,2 & 74,3 \\
NUCLEAR & 12.957 & 14.523 & 12,1 & 2,6 & 2,7 \\
GÁS NATURAL & 13.332 & 30.830 & 131,2 & 2,6 & 5,7 \\
CARVÄO MINERAL & 5.214 & 7.098 & 36,1 & 1,0 & 1,3 \\
DERIVADOS DE PETRÓLEO & 12.724 & 14.645 & 15,1 & 2,5 & 2,7 \\
BIOMASSA & 22.639 & 28.019 & 23,8 & 4,5 & 5,1 \\
GÁSINDUSTRIAL & 7.066 & 8.165 & 15,5 & 1,4 & 1,5 \\
EÓLICA & 1.238 & 2.177 & 75,8 & 0,2 & 0,4 \\
IMPORTAÇÄO & 39.984 & 34.369 & $-14,0$ & 7,9 & 6,3 \\
TOTAL & $\mathbf{5 0 6 . 1 4 1}$ & $\mathbf{5 4 4 . 8 8 0}$ & $\mathbf{7 , 7}$ & $\mathbf{1 0 0 , 0}$ & $\mathbf{1 0 0 , 0}$ \\
\hline
\end{tabular}

Notas: (a) inclui 40,4 TWh de autoprodutor cativo em 2010 (que não usa a rede básica); (b) Gás industrial inclui gás de alto forno, gás siderúrgico, gás de coqueria, gás de processo, gás de refinaria, enxofre e alcatrão

Tabela 9: Oferta Interna de Energia Elétrica (OIEE) (GWh e \%).

Fonte: Resenha Energética Brasileira - Exercício de 2010 (Preliminar) - Maio de 2011.

Comparando os anos de 2011 e 2010, de acordo com a Resenha Energética Brasileira (exercício de 2011) a geração eólica continuou com forte expansão apesar do seu aumento de $24 \%$, mesmo sendo inferior em relação ao crescimento de 2009/2010 (76\%). Ainda com relação à geração a biomassa, registrou crescimento de apenas $2,1 \%$, mas a referida resenha justifica que foi devido ao fraco desempenho da geração por bagaço de cana, em razão do recuo de $18 \%$ na produção de etanol e recuo de $3 \%$ na produção de açúcar; mesmo assim, a geração a bagaço de cana representa $69 \%$ da geração total por biomassa. 
A tabela 10, a seguir, ilustra a Oferta Interna de Energia Elétrica (OIEE), referente ao ano de 2011 em comparação ao ano de 2010. Importante observar que continou em 2011, o forte crescimento da geração eólica.

\begin{tabular}{|c|c|c|c|c|c|}
\hline \multirow{2}{*}{ Especificação } & \multicolumn{2}{|c|}{ GWh } & \multirow{2}{*}{$11 / 10 \%$} & \multicolumn{2}{|c|}{ Estrutura (\%) } \\
\hline & 2010 & 2011 & & 2010 & 2011 \\
\hline Hidráulica & 403.290 & 428.571 & 6,3 & 73,3 & 75,4 \\
\hline Nuclear & 14.523 & 15.659 & 7,8 & 2,6 & 2,8 \\
\hline Gás Natural & 36.476 & 26.242 & $-28,1$ & 6,6 & 4,6 \\
\hline Carvão Mineral & 6.992 & 6.530 & $-6,6$ & 1,3 & 1,1 \\
\hline Derivados de Petróleo & 14.216 & 12.117 & $-14,8$ & 2,6 & 2,1 \\
\hline Biomassa & 31.545 & 32.197 & 2,1 & 5,7 & 5,7 \\
\hline Gás Industrial & 6.580 & 8.851 & 34,5 & 1,2 & 1,6 \\
\hline Eólica & 2.177 & 2.705 & 24,2 & 0,4 & 0,5 \\
\hline Importação & 34.648 & 35.886 & 3,6 & 6,3 & 6,3 \\
\hline TOTAL & 550.447 & 568.758 & 3,3 & 100,0 & 100,0 \\
\hline
\end{tabular}

Tabela 10: Oferta Interna de Energia Elétrica (OIEE) (GWh e \%).

Fonte: Resenha Energética Brasileira - Exercício de 2011 (Preliminar) - Maio de 2012.

Pode-se verificar também na figura 28, a seguir, na matriz de Oferta Interna de Energia Elétrica (OIEE), as vantagens comparativas de $86 \%$ de fontes renováveis na matriz elétrica brasileira, contra apenas $17 \%$ nos países da OECD ${ }^{21}$ e de $19 \%$ na média mundial.

Já na matriz de Oferta Interna de Energia Elétrica (OIEE), referente a Resenha Energética Brasileira de 2011, oberva-se as vantagens comparativas de $88 \%$ de fontes renováveis na matriz elétrica brasileira, contra apenas $18 \%$ nos países OECD e de $20 \%$ na média nacional. Verifica-se um pequeno aumento, comparando-se 2011 com 2010 em relação à comparação de 2010 com 2009. Vide figura 29 a seguir.

${ }^{21}$ OECD são os 30 países membros da Organisation de Coopération et Développement Économiques: Alemanha, Austrália, Áustria, Bélgica, Canadá, Coréia do Sul, Dinamarca, Espanha, Estados Unidos, Finlândia, França, Grécia, Holanda, Hungria, Irlanda, Islândia, Itália, Japão, Luxemburgo, México, Noruega, Nova Zelândia, Polônia, Portugal, Reino Unido,República Tcheca, Suiça e Turquia. Além desses países, também integra a OCDE a União Euopéia. 


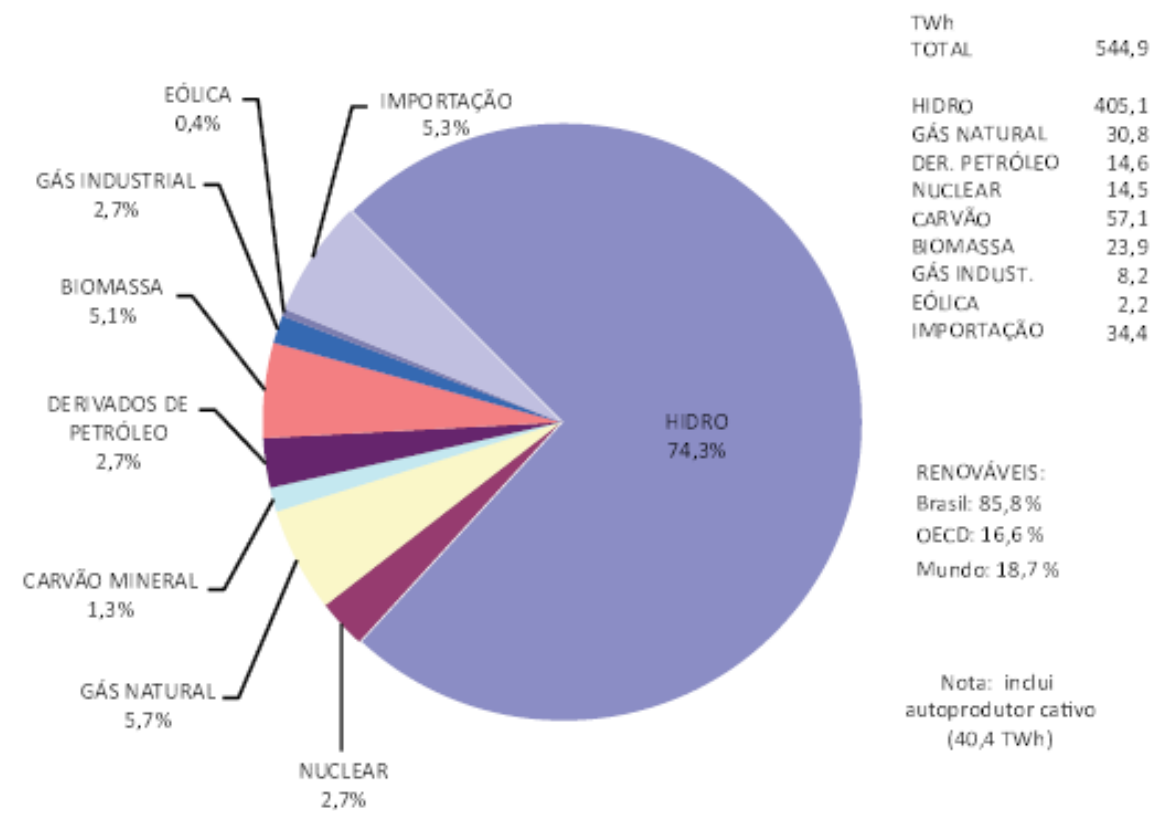

Figura 28: Oferta Interna de Energia Elétrica (OIEE).

Fonte: Resenha Energética Brasileira - Exercício de 2010 (Preliminar) - Maio de 2011.

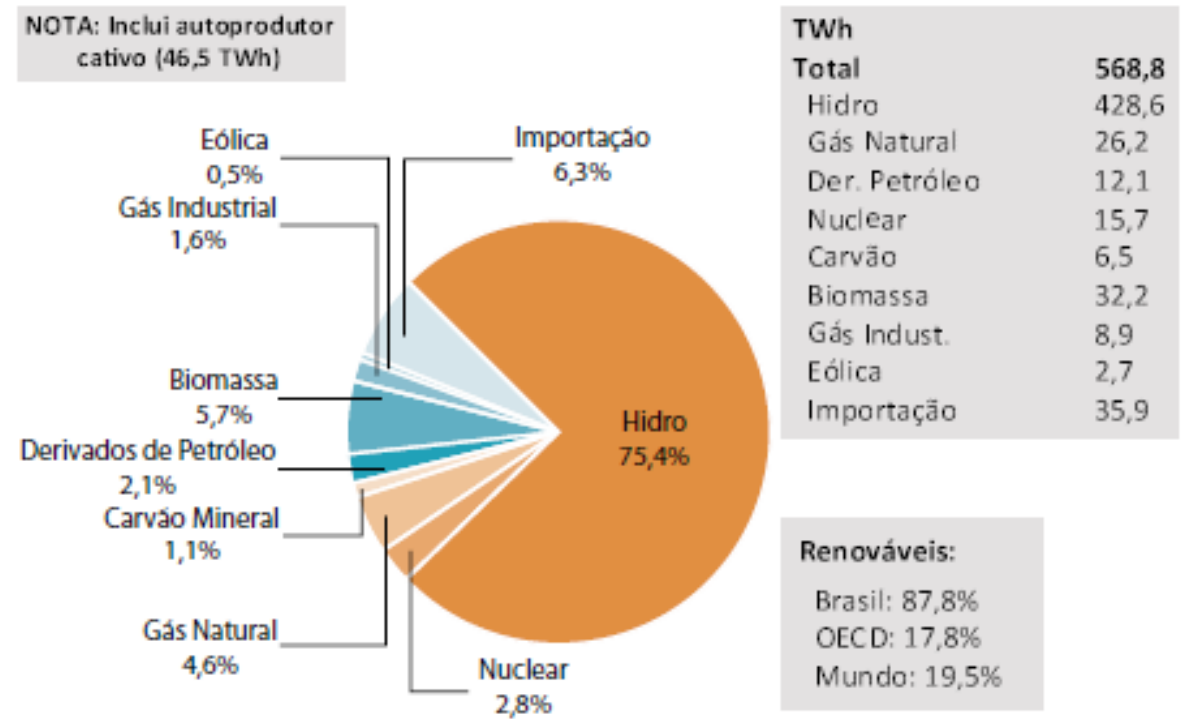

Figura 29: Oferta Interna de Energia Elétrica (OIEE).

Fonte: Resenha Energética Brasileira - Exercício de 2011 (Preliminar) - Maio de 2012.

Cabe acrescentar ainda que, os Planos Decenais de Expansão de Energia 2020 e 2021 (PDE), que apresentam o planejamento energético da expansão da demanda e da oferta de diversos energéticos, consideram ser um importante instrumento para a 
delimitação do cenário de mitigação, uma vez que incorpora medidas que, em conjunto, contribuem para a diminuição da emissão de GEE, como o incremento do parque instalado de hidroeletricidade e fontes alternativas de energia elétrica como eólica, biomassa e PCHs, além da avaliação das áreas de expansão da cana necessárias para o aumento do volume de biocombustíveis e consequente substituição de combustíveis fósseis, que também estão entre as medidas incorporadas.

Quanto à biomassa de cana de açúcar para a geração de bioeletricidade, a avaliação da quantidade de energia já contratada pelo setor elétrico e a análise de seu potencial técnico, evidenciaram uma significativa folga para ampliação de sua capacidade, o que possibilitaria sua consolidação como uma fonte importante na matriz elétrica nacional, em consonância com as diretrizes definidas para a expansão da geração através de fontes renováveis [7].

O PDE 2020 considera ainda a priorização da participação das fontes renováveis de energia, com destaque para as grandes e pequenas centrais hidrelétricas, usinas eólicas e as usinas movidas a biomassa, para atendimento ao crescimento do consumo de energia elétrica no horizonte decenal.

Já, de acordo com o PDE 2021, em continuidade com os planos anteriores, o conceito de sustentabilidade orientou os estudos socioambientais desenvolvidos para este Plano. O foco em alternativas de maior sustentabilidade está balizado pelas atuais discussões e negociações internacionais sobre mudançcas do clima, conforme evidenciado em Copenhague (COP-15). Em âmbito nacional, a questão climática teve sua relevância reiterada na promulgação da Lei $n^{\circ} 12.187 / 09$ e do Decreto $n^{\circ} 7.390 / 10$, que regulamenta esta lei. Esse novo arcabouço legal, que instituiu a Política Nacional sobre Mudançca do Clima e estabeleceu a meta de redução das emissões de gases de efeito estufa em 36,1 a 38,9\% em relação a um cenário de referência para 2020, desloca as discussões sobre mudanças climáticas, no Brasil, para um novo patamar institucional. Um dos destques é que o referido Decreto estabeleceu que, no setor de energia, o plano setorial de mitigação às mudanças do clima é o próprio Plano Decenal de Energia. [43] 
Ainda, o PDE 2021 tem em seus objetivos o atendimento a metas específicas no quesito "emissões absolutas do setor elétrico como um todo", no ano de 2020, sendo outra meta relacionada ao indicador de carbono da economia, que não deverá ultrapassar o valor registrado em 2005.

Faz-se importante ilustrar, no gráfico 2, a seguir, a evolução da capacidade instalada hidrotérmica por tipo de fonte, partindo de aproximadamente $116 \mathrm{GW}$, em dezembro de 2010, para cerca de $182 \mathrm{GW}$, no final de 2021, com destaque para a manutenção do perfil fortemente renovável da matriz elétrica brasileira.

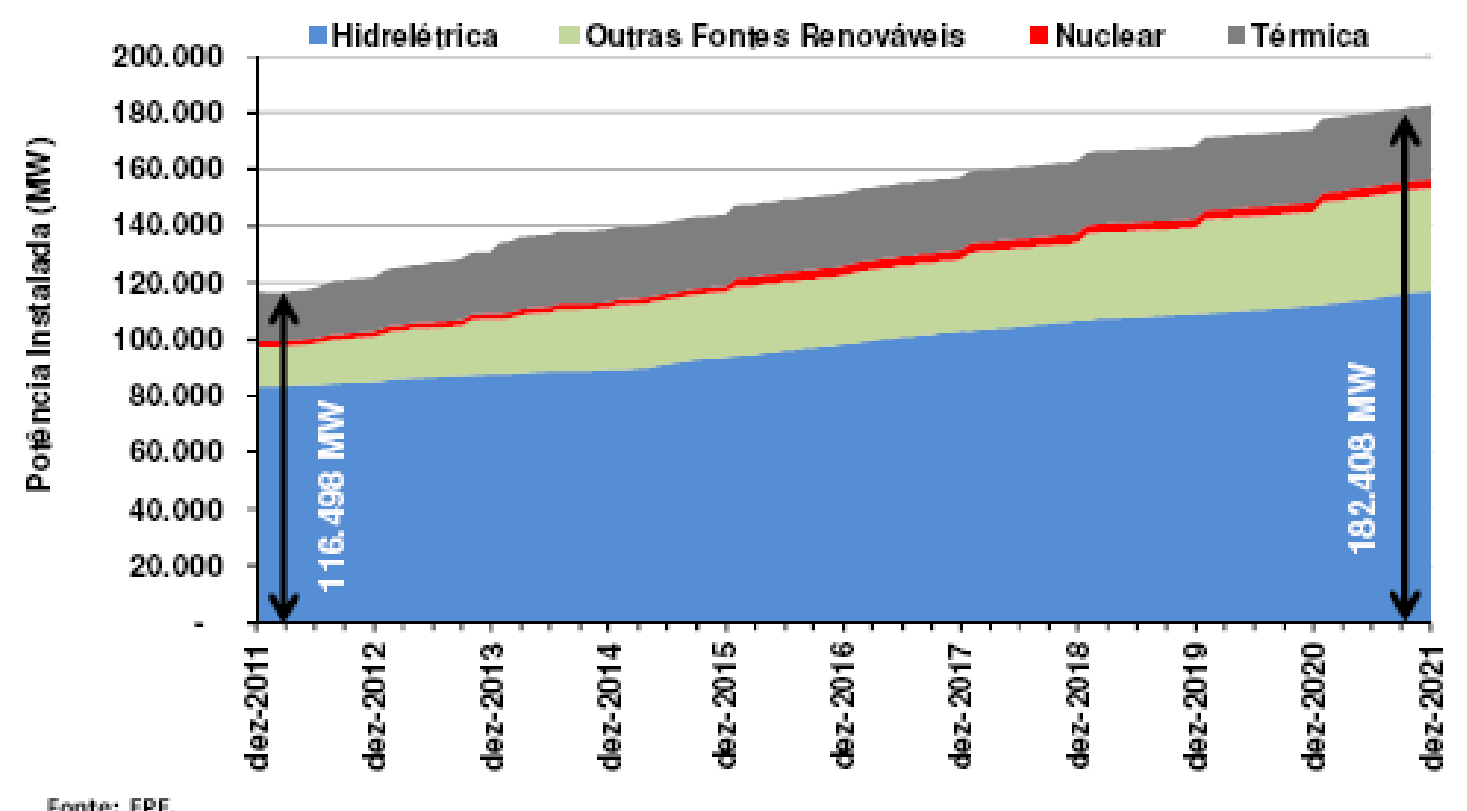

Gráfico 2: Representação reginal da capacidade instalada no SIN.

(Obs. Para os projetos que completam sua motorização ao longo de vários anos, foi considerada a motorização parcial para o cálculo da evolução da capacidade instalada.)

Fonte: PDE 2021

Com relação ao PROINFA, o PDE considera os empreendimentos contratados de acordo com o cronograma do CMSE, que ao final de 2011, foram instalados 2.889 MW de potência distribuidos em 132 empreendimentos. No PDE 2021, vide tabela 11 a seguir, foram considerados 134 empreendimentos, sendo 62 pequenas centrais hidrelétricas ( $\mathrm{PCH}$ 's), 21 usinas termelétricas a biomassa (BIO) e 51 usinas eólicas (EOL), onde a previsão de entrada comercial ficou para janeiro de 2014. 
A tabela 11, a seguir, apresenta a expansão da biomassa, $\mathrm{PCH}$ e eólica de 2012 a 2016, distribuído por região e por ano:

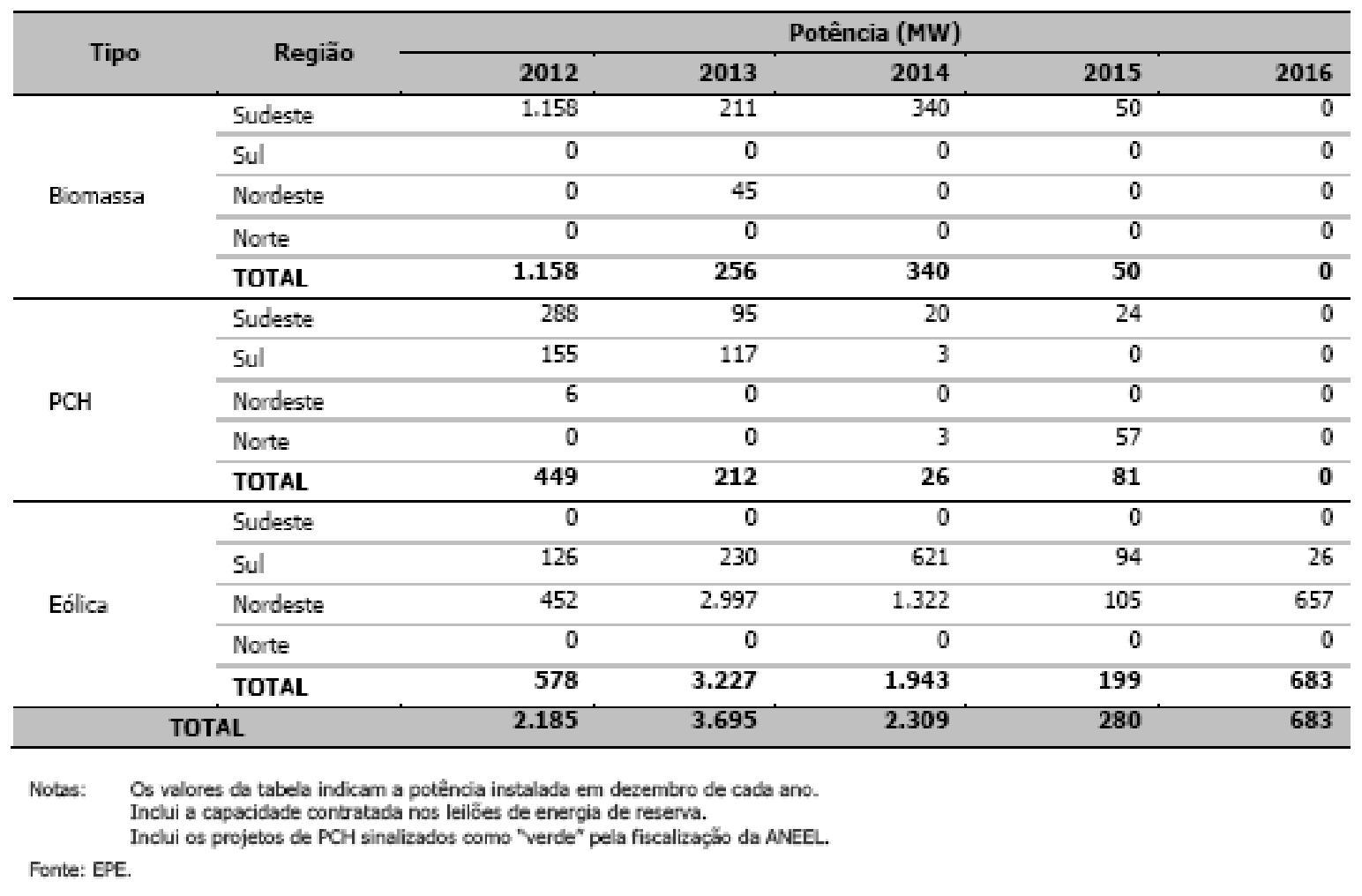

Tabela 11: Expansão de biomassa, PCH e eólica de 2012 a 2016.

Fonte: PDE 2021

Com relação às outras fontes renováveis de geração consideradas no PDE 2021 eólicas, térmicas movidas a biomassa, em sua maioria de bagaço de cana-deaçucar, e as PCH's - nota-se uma expansão média de 10\%, com destaque às usinas eólicas. A região Sudeste/Centro-Oeste mantém a maior participação dessas fontes ao longo do horizonte de tempo, como pode ser visto no gráfico 3 , a seguir.

Vale a pena frisar ainda como resultado do gráfico 3 que, com relação às fontes alternativas, o PDE 2020 também já havia verificado uma expansão média anual de $12 \%$, com destaque para as usinas eólicas, a biomassa de bagaço de cana-deaçúcar e PCH. A região Sudeste/Centro-Oeste mantém a maior participação dessas fontes ao longo do horizonte de tempo do estudo. 


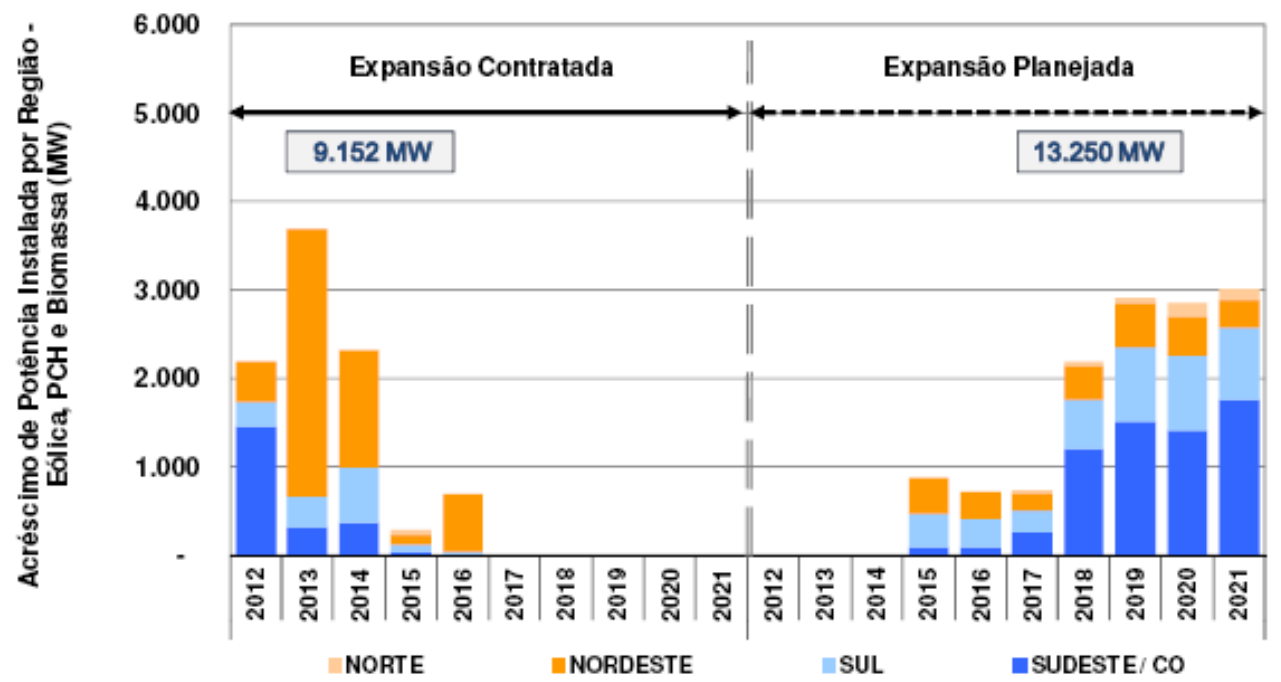

FONTE: EPE.

Gráfico 3: Acréscimo de capacidade instalada de outras fontes renováveis (MW).

Fonte: EPE - PDE 2021.

Foi observado que a expansão das fontes alternativas - biomassa, PCH e eólica faz a sua participação no parque de geração do SIN passar de 16\%, em 2015, para $20 \%$, em 2021, distribuídos basicamente entre as regiões Sudeste/Centro-Oeste, Nordeste e Sul. Em contrapartida, as usinas termelétricas perdem participação perante as demais fontes, caindo de $18 \%$ para $14 \%$, no ano final.

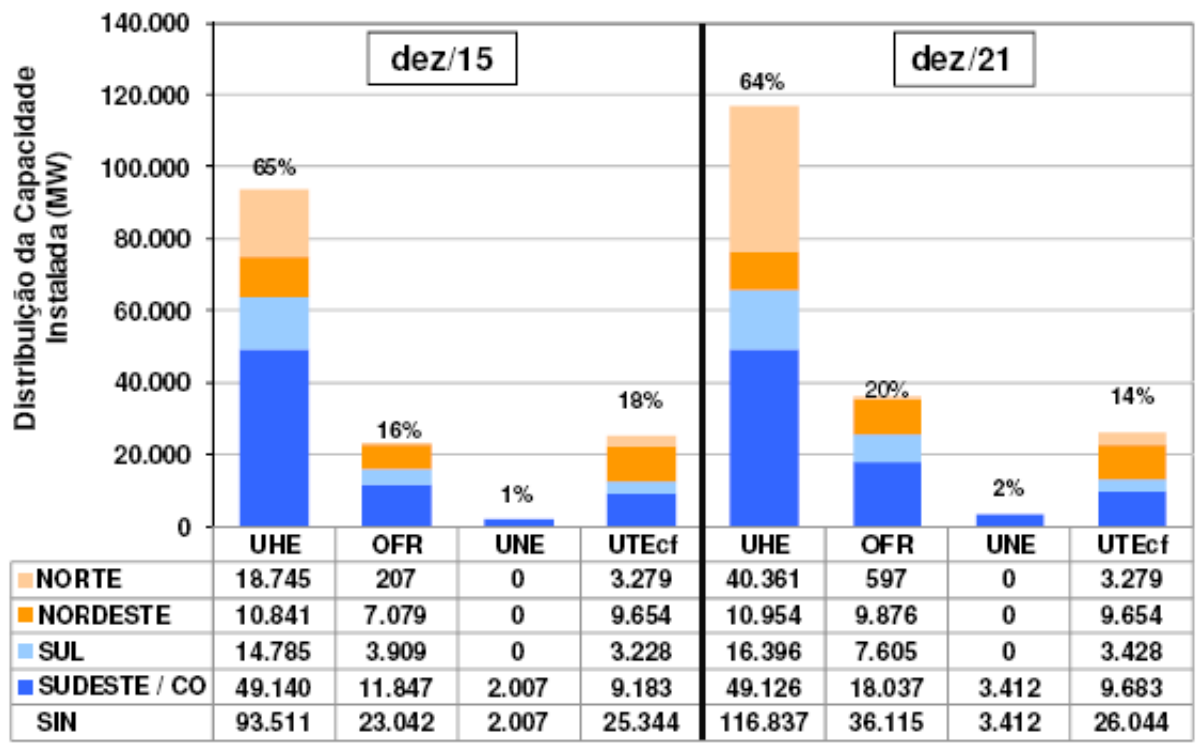

Legenda: UHE-usinas hidrelétricas; OFR-outras fontes renováveis; UNE-usinas nucleares; UTEcf -usinas termelétricas FONTE: EPE.

Gráfico 4: Participação das fontes de produção em 2015 e em 2021 (MW).

Fonte: EPE - PDE 2021 
No gráfico 5, a seguir, destaca-se a retomada da participação das fontes renováveis na matriz elétrica a partir do ano de 2014 , em detrimento das fontes baseadas em combustíveis fósseis.

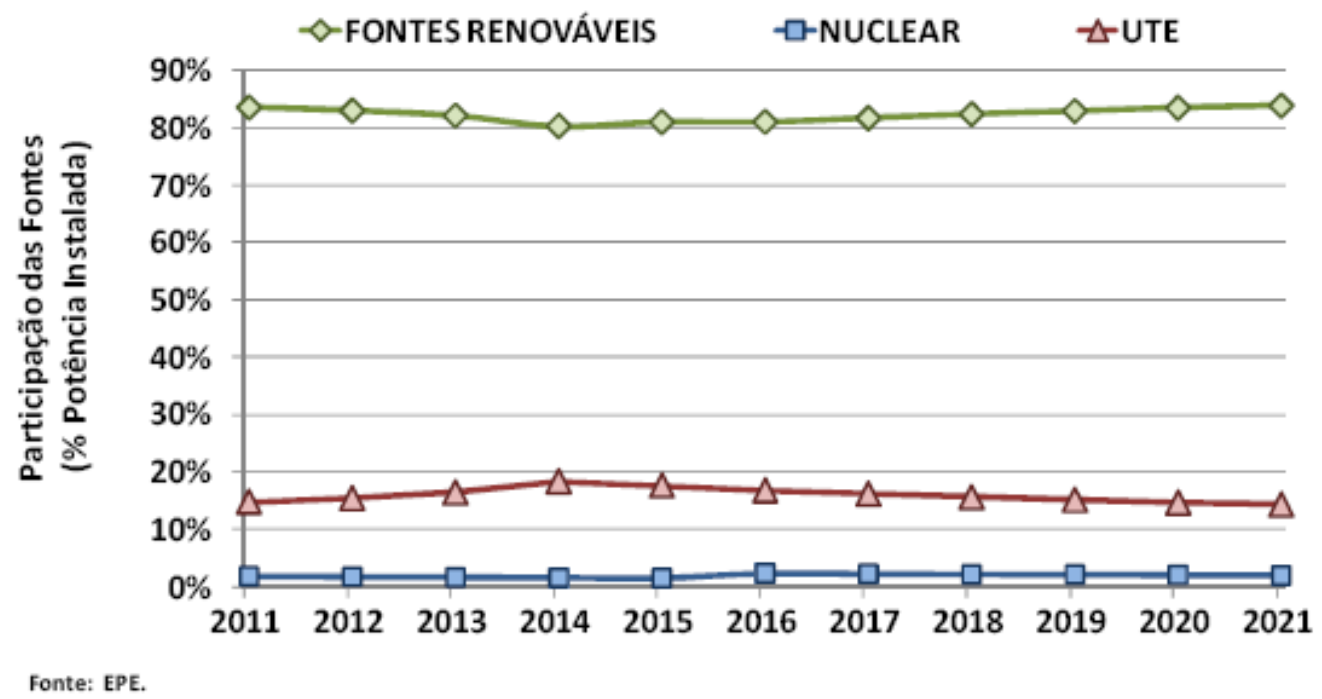

Gráfico 5: Evolução da participação das fontes de produção na capacidade instalada do SIN (\%). Fonte: EPE - PDE 2021.

O gráfico 6, a seguir, apresenta a evolução da capacidade instalada para diferentes fontes de geração ao longo do período de estudo, sendo ilustrado o seu comportamento no final dos anos 2011, 2015 e 2021.
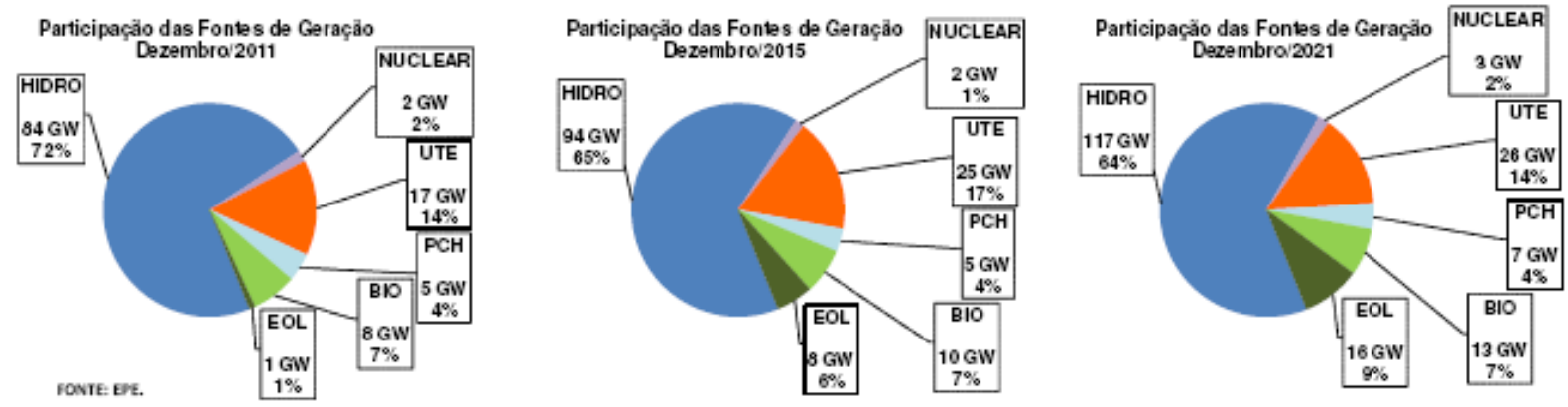

Gráfico 6: Evolução da capacidade instalada por fonte de geração (GW e \%).

Fonte: EPE - PDE 2021.

Faz-se importante ressaltar o crescimento no período de 2011 a 2021, apresentado no gráfico 6, acima, das fontes altenativas de energia ( $\mathrm{PCH}$, biomassa e eólica). 
No gráfico 7, a seguir, é apresentada a expansão contratada e a planejada por tipo de fonte. Observa-se a priorização das usinas hidrelétricas e das fontes alternativas no horizonte de planejamento.

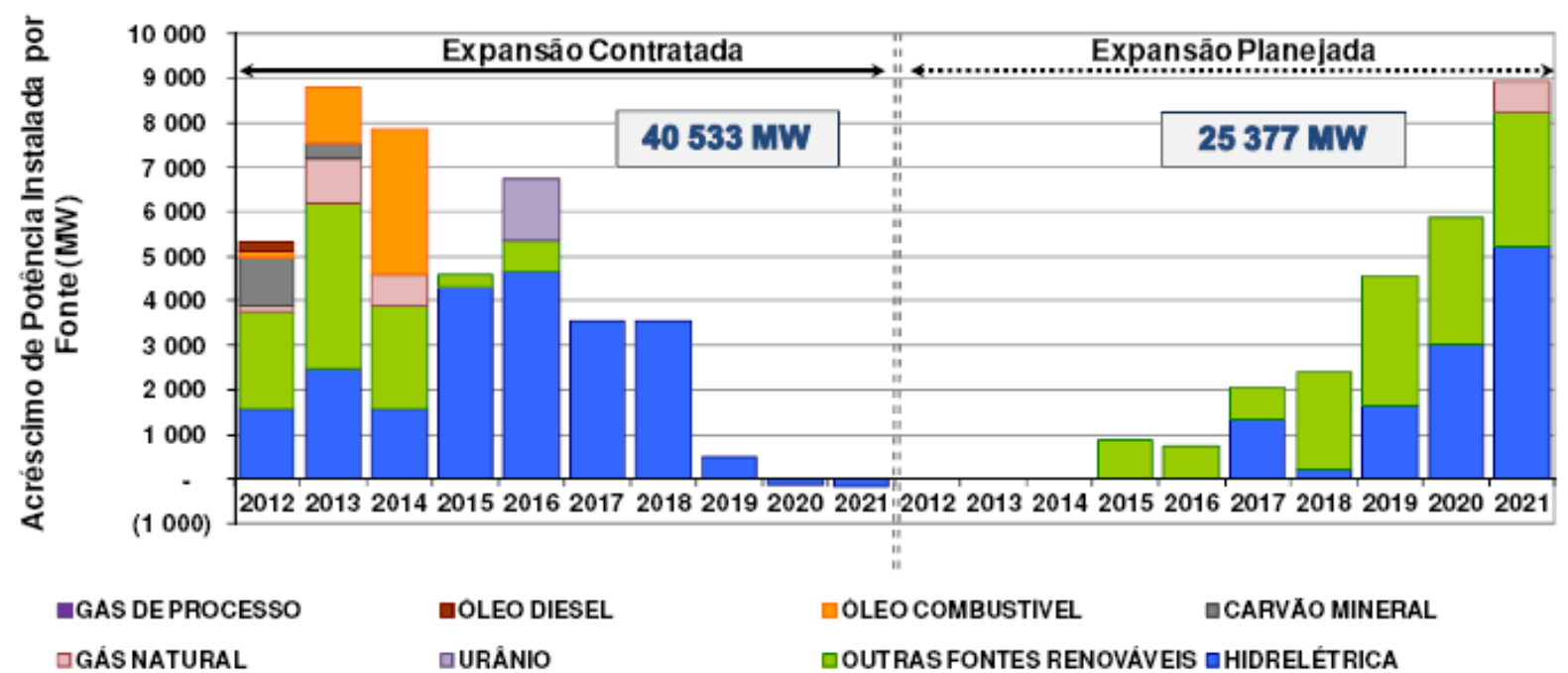

FONTE: EPE.

Gráfico 7: Acréscimo de capacidade instalada anual por fonte (MW).

Fonte: EPE - PDE 2021

Com relação às estimativas de investimentos, a expansão em geração, no período 2012 a 2021, requer investimentos da ordem de $R \$ 213$ bilhões. Cabe ressaltar que grande parte destes investimentos refere-se às usinas já autorizadas; entre estas, as usinas com contratos assinados nos leilões de energia nova. O montante a investir em novas usinas, ainda não contratadas ou autorizadas (planejadas) é da ordem de $\mathrm{R} \$ 117$ bilhões, sendo $57 \%$ em hidrelétricas e $42 \%$ no conjunto de outras fontes renováveis $(\mathrm{PCH}+$ biomassa + eólica).

A tabela 12, a seguir, apresenta a composição do custo de investimento por tipo de fonte de geração. 


\begin{tabular}{|c|c|c|c|c|c|c|}
\hline \multirow[t]{2}{*}{ TIPO DE FONTE } & \multicolumn{2}{|c|}{$\begin{array}{c}\text { Usinas contratadas e } \\
\text { autorizadas }\end{array}$} & \multicolumn{2}{|c|}{ Usinas planejadas } & \multicolumn{2}{|c|}{ TOTAL } \\
\hline & Bilhôes R\$ & $\%$ & Bilhões R\$ & $\%$ & Bilhões R\$ & $\%$ \\
\hline HIDRO & 40,9 & $43 \%$ & 67,3 & $57 \%$ & 108,2 & $51 \%$ \\
\hline TERMELÉTRICA & 21,6 & $23 \%$ & 1,3 & $1 \%$ & 22,9 & $11 \%$ \\
\hline - Nuclear & 6,2 & $7 \%$ & 0,0 & $0 \%$ & 6,2 & $3 \%$ \\
\hline - Gás natural & 3,0 & $3 \%$ & 1,3 & $1 \%$ & 4,3 & $2 \%$ \\
\hline - Carvão & 2,4 & $3 \%$ & 0,0 & $0 \%$ & 2,4 & $1 \%$ \\
\hline - Óleo combustivel/diesel & 10,0 & $10 \%$ & 0,0 & $0 \%$ & 10,0 & $5 \%$ \\
\hline PCH + BIOMASSA +EÓLICA & 33,3 & $34 \%$ & 48,8 & $42 \%$ & 82,1 & $38 \%$ \\
\hline $\begin{array}{ll}\text { TOTAL } \\
\end{array}$ & 95,8 & $100 \%$ & 117,4 & $100 \%$ & 213,2 & $100 \%$ \\
\hline
\end{tabular}

Notas: Os investimentos abrangem as parcelas de desembolso que ocorrem no período decenal. Fonte: EPE.

Tabela 12: Estimativa de investimentos em geração de energia.

Fonte: EPE - PDE 2021.

O Balanço Energético Nacional (BEN), que é uma análise da matriz energética brasileira trazendo dados sobre a oferta e a demanda de energia, apresenta em seu estudo que, em 2011, com acréscimo de aproximadamente $5 \mathrm{GW}$, a capacidade instalada das centrais de geração elétrica no Brasil alcançou 117.135 MW, na soma das centrais de serviço público, de produção independente e autoprodutoras, sendo que deste total, $10,5 \%$ correspondem às usinas eólicas.

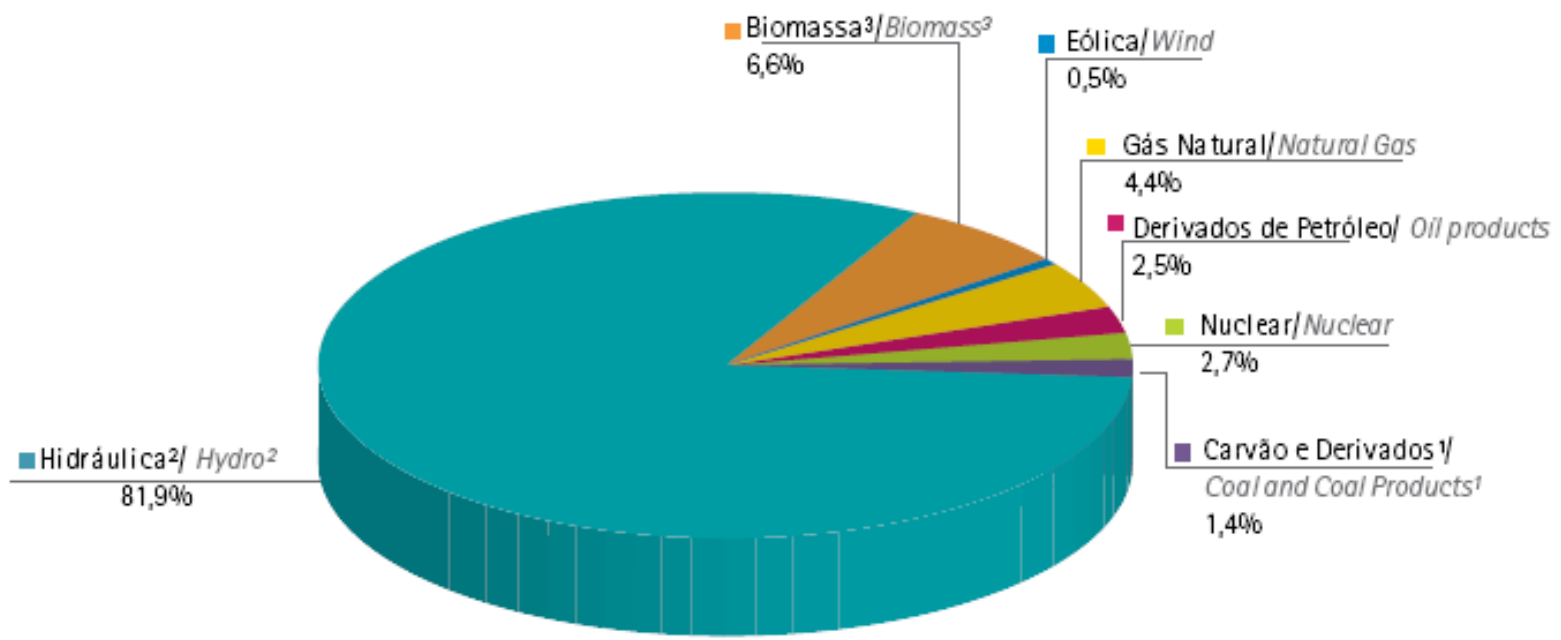

Notas/ Notes:

' Inclui gás de coqueria/ hcludes coke oven gas

${ }^{2}$ Inclui importaçao de eletricidade/ includes electricity imports

3 Indui lenha, bagaço de cana, lixlvia e outras recuperaçoes/ Includes firewood, sugarcane bagasse, block-liquor and other primary sources

Gráfico 8: Oferta Interna de Energia Elétrica por Fonte de Eletricidade no Brasil em 2011.

Fonte: EPE - BEN 2012 
Ainda, de acordo com o BEN 2012, somando as importações, que essencialmente também são de origem renovável, pode-se afirmar que aproximadamente $86 \%$ da eletricidade no Brasil é originada de fontes renováveis.

\subsection{Perspectiva de Redução de Emissões}

\subsubsection{Plano Nacional de Mudança do Clima (PNMC)}

O objetivo geral do Plano Nacional sobre Mudança do Clima é identificar, planejar e coordenar as ações e medidas que possam ser empreendidas para mitigar as emissões de gases de efeito estufa no Brasil, bem como estabelecer as ações necessárias à adaptação da sociedade aos impactos que ocorram devido à mudança do clima [7].

\subsubsection{Emissões de Gases de Efeito Estufa (GEE)}

A mudança global do clima causada pelas emissões antrópicas tem sido incluída na pauta das principais questões sócioambientais a serem enfrentadas ao longo deste século. O Brasil, signatário da UNFCCC ${ }^{22}$, em razão da temporalidade e do estágio de seu desenvolvimento econômico, não está obrigado a atender a metas quantitativas de redução de emissões de GEE no âmbito do Protocolo de Quioto, no qual países desenvolvidos listados em seu Anexo I, se comprometem a reduzir, no período de 2008 a 2012, as respectivas emissões em $5 \%$ dos valores verificados em $1990[7]$.

Apesar de não estar vinculado ao compromisso de redução, o Brasil, assim como outros países signatários da UNFCCC, tem empreendido esforços no sentido de mitigar suas emissões como forma de contribuir para o objetivo global de estabilizar a concentração de GEE na atmosfera, princípio basilar da convenção.

Em dezembro de 2009, na $15^{\circ}$ Conferência das Partes (COP-15), realizada em Copenhague, o Brasil anunciou meta voluntária de reduzir, em 2020, entre 36,1 e $38,9 \%$ de suas emissões totais de GEE projetadas para aquele ano.

\footnotetext{
${ }^{22}$ UNFCC: Sigla em inglês da Convenção-Quadro das Nações Unidas sobre Mudança do Clima (United Nations Framework Convention on Climate Change)
} 
Essa meta foi formalizada pela Lei $n^{\circ} 12.187 / 2009$, que entre outras providências, instituiu a Política Nacional sobre Mudança do clima [7].

Por meio do Mecanismo de Desenvolvimento Limpo (MDL), uma Parte dos países do Anexo I pode comprar reduções certificadas de emissões resultantes de atividades de projeto desenvolvidas em qualquer país em desenvolvimento que tenha ratificado o Protocolo, desde que o governo do país anfitrião concorde que a atividade de projeto é voluntária e contribui para o desenvolvimento sustentável nacional e, ao mesmo tempo, para que as reduções de emissão ou remoções de gases de efeito estufa sejam certificadas dentro dos procedimentos e regras estabelecidas no âmbito do Protocolo [2].

Assim, o MDL é uma oportunidade para as companhias brasileiras desenvolverem projetos de redução de emissão, como, por exemplo, pelo uso de energias renováveis.

De acordo com o Plano Nacional de Mudança do Clima (PNMC), quanto à redução de emissões de GEE projetadas por meio do MDL no mundo, o potencial brasileiro é de aproximadamente 312 milhões de toneladas de dióxido de carbono equivalente CO2eq - 6\% do total mundial - para o primeiro período de obtenção de créditos (no máximo 10 anos para projetos de período fixo ou de 7 anos para projetos de período renovável). Anualmente, esse potencial de redução é de aproximadamente 41 milhões de toneladas de dióxido de carbono equivalente [2].

De acordo com a Resenha Energética Brasileira do Exercício de 2010, a expressiva participação da energia hidráulica e o uso representativo da biomassa na matriz energética brasileira proporcionam indicadores de emissões de $\mathrm{CO}_{2}$ bem menores do que a média mundial e dos países desenvolvidos. No país, a emissão de 2010 pelo uso da energia ficou em 1,45 toneladas de $\mathrm{CO}_{2}$ por tep da Oferta Interna de Energia (OIE), enquanto que nos países da OECD esse indicador ficou em 2,33 $\mathrm{tCO}_{2}$ /tep de OIE (2008), e no mundo ficou em 2,4 $\mathrm{tCO}_{2} /$ tep (2008). A China e os Estados Unidos, com 12.140 milhões de $t$ de emissões de $\mathrm{CO}_{2}$, responderam por $41 \%$ das emissões mundiais de 2008 , no montante de 29.380 milhões de $\mathrm{tCO}_{2}$.

O gráfico 9 , a seguir, apresenta estimativas de níveis de emissões de $\mathrm{CO}_{2}$ no período compreendido do ano de 2006 a 2015. 


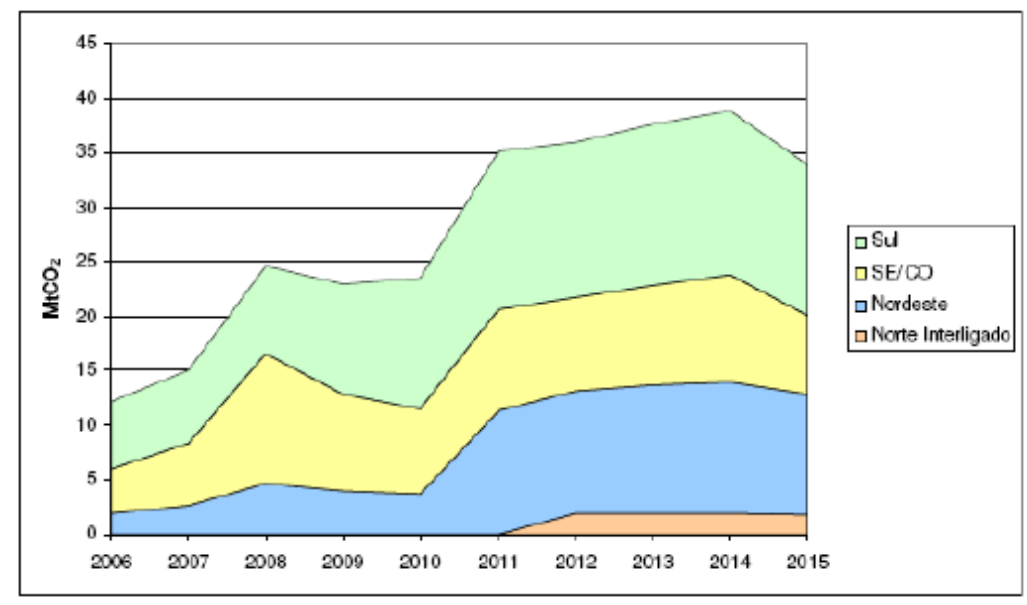

Gráfico 9: Estimativas de Níveis das emissões de $\mathrm{CO} 2$.

Fonte: Aula 3, PEA-5001 - Métodos de quantificação de créditos de carbono no setor elétrico brasileiro utilizando-se os Mecanismos do Protocolo de Quioto [31]. 


\section{COMPLEMENTAÇÃO ENERGÉTICA ENTRE FONTES INCENTIVADAS}

\subsection{Geração Hidrelétrica}

As precipitações pluviométricas que abastecem os reservatórios com água não ocorrem de modo uniforme ao longo do ano. Existem meses em que a pluviosidade é maior que a média e meses em que a mesma é menor que a média.

O período úmido vai, normalmente, de dezembro a abril, enquanto os demais meses compõem o período chamado período seco (maio a novembro).

Acrescente-se ainda que a exigência de carga não ocorre de modo uniforme ao longo das horas do dia, ao longo dos dias da semana e do ano.

Em um sistema como o SIN, no qual as usinas são integradas, algumas são projetadas para gerar energia em regimes diferentes em tempos de programação de horas a produzir. Uma usina de base é operada de forma a produzir energia com uma carga constante, enquanto a usina de ponta é normalmente operada de forma a produzir energia complementar, específico para cobrir os períodos de carga do sistema elétrico (chamado patamar de carga pesada).

\subsection{Caracterização da Complementaridade entre Energia Eólica e a Hidroeletricidade}

A energia eólica é renovável, considerada ambientalmente limpa e contribui na redução da emissão de gases de efeito estufa. Além disso, em razão da possibilidade de complementação de sua energia produzida com a geração hidrelétrica é merecedora de bastante atenção.

A inserção de uma nova fonte na matriz de insumos energéticos é um processo que principia pelo levantamento do potencial e aquisição de conhecimento sobre a tecnologia; evolui com a inclusão dos empreendimentos no planejamento da expansão e conclui com a contratação dos empreendimentos à medida que a tecnologia se torna competitiva. 
No caso da energia eólica, há uma estimativa do potencial brasileiro e medições em locais específicos, mas ainda não há um histórico que permita uma avaliação mais precisa do potencial e do benefício energético da geração eólica em operação no sistema hidrotérmico brasileiro [12]. A figura 28, a seguir, demonstra que com exceção da região amazônica, o potencial dos ventos se distribui pelo território nacional, sendo mais intenso nos meses de junho a dezembro, o que coincide com o período seco hidrelétrico.

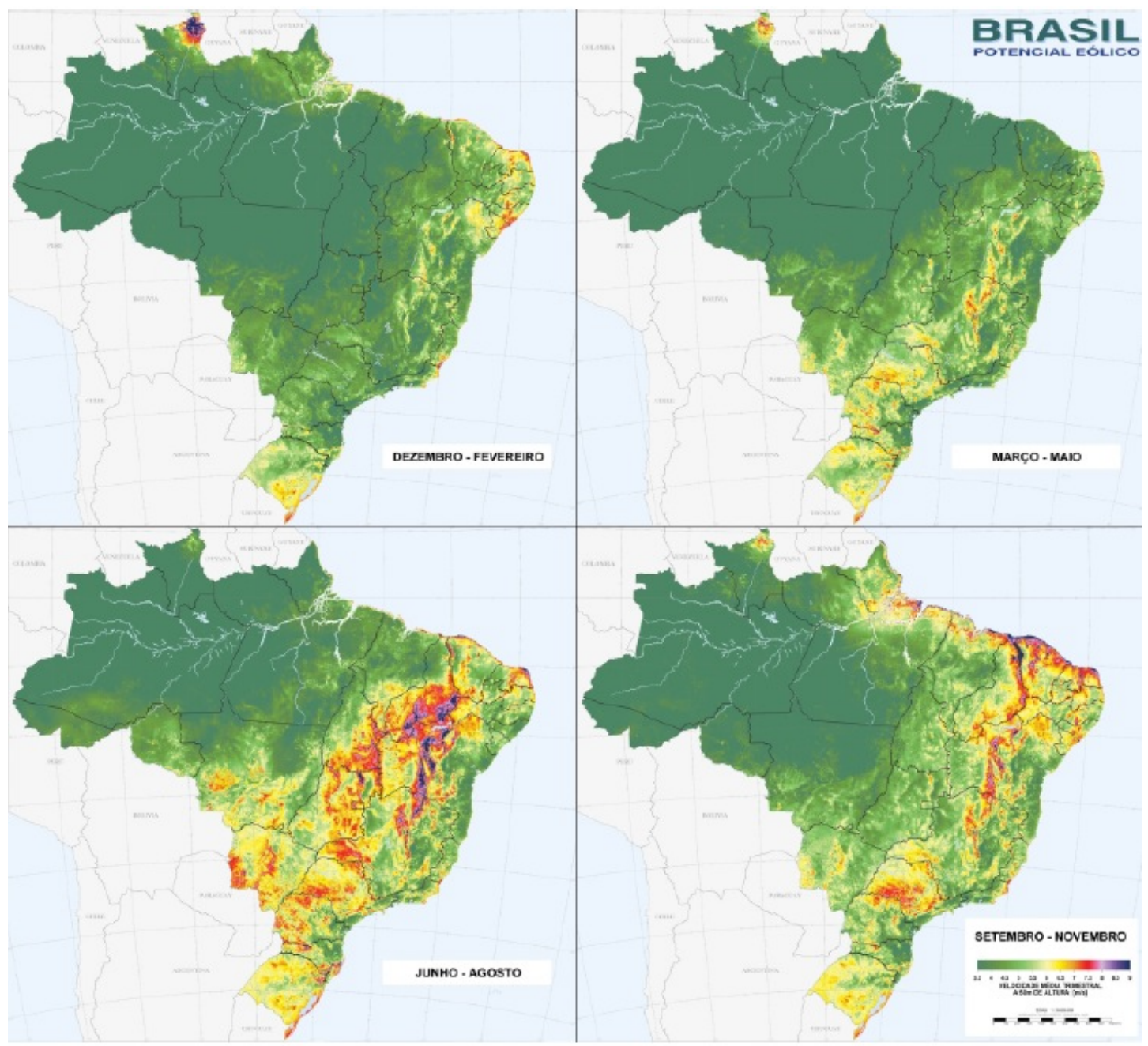

Figura 30: Atlas do Potencial Eólico Brasileiro.

Fonte: CEPEL - Centro de Pesquisas de Energia Elétrica [27].

A região nordeste é particularmente favorecida pelos ventos, não apenas na faixa costeira que abrange o Rio Grande do Norte, Ceará, Piauí e Maranhão, mas também na faixa interiorana que se inicia no mar do Piauí até o norte de Minas Gerais, estendendo-se por cerca de 1.500 km [12]. 
Em relação às características da energia eólica no país, tem-se que os regimes de vento e de afluências são complementares na região nordeste do Brasil, onde não somente o potencial brasileiro de energia é alto, mas também onde se tem importado energia de outra áreas do país. Na região Nordeste, quando os reservatórios das usinas hidrelétricas estão em seu nível mais baixo, há maior intensidade de ventos, proporcionando uma complementariedade entre as fontes eólica e hidrelétrica, o que poderia, dependendo da capacidade eólica instalada, garantir o suprimento de energia contínuo na região durante todo o ano [13].

Com informações obtidas a partir do Operador Nacional do Sistema Elétrico (ONS), foram feitos os gráficos a seguir para demonstrar a questão da sazonalidade e também uma comparação da geração de energia eólica no SIN, Norte e Nordeste, Sul Sudeste e Centro Oeste. O gráfico a seguir apresenta o crescimento significativo da geração de energia eólica no SIN, a partir do ano de 2006, em termos de MW médios. (Os dados obtidos para a geração dos gráficos representados pelos gráficos 10,11 e 12, a seguir, estão apresentados no apêndice B deste trabalho).

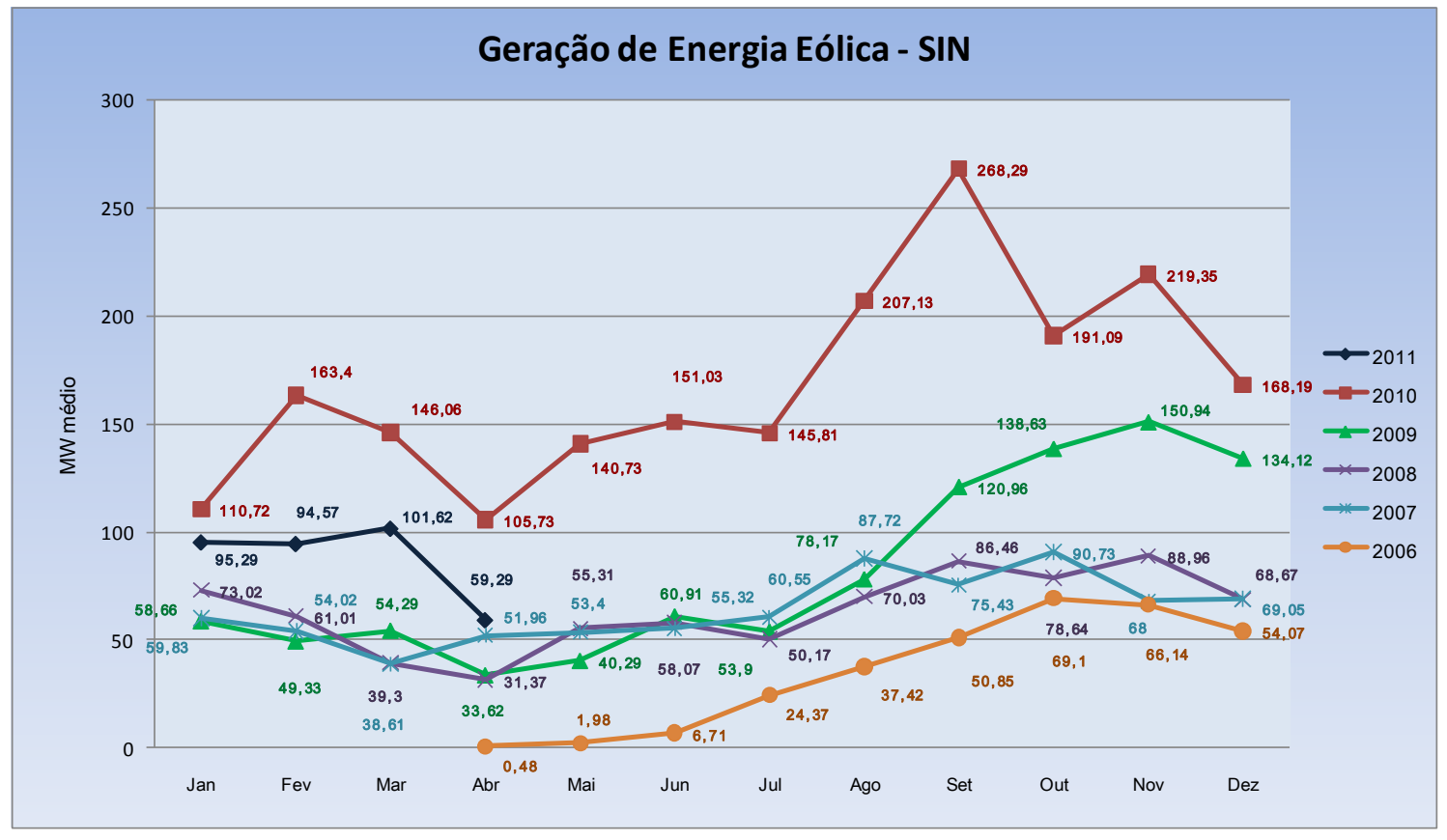

Gráfico 10: Gráfico de Geração de Energia Eólica - SIN.

Fonte: Elaboração a partir de informações do ONS (www.ons.org.br)

A região Nordeste é favorecida pelos ventos, conforme já dito e pode ser verificado no gráfico a seguir: 


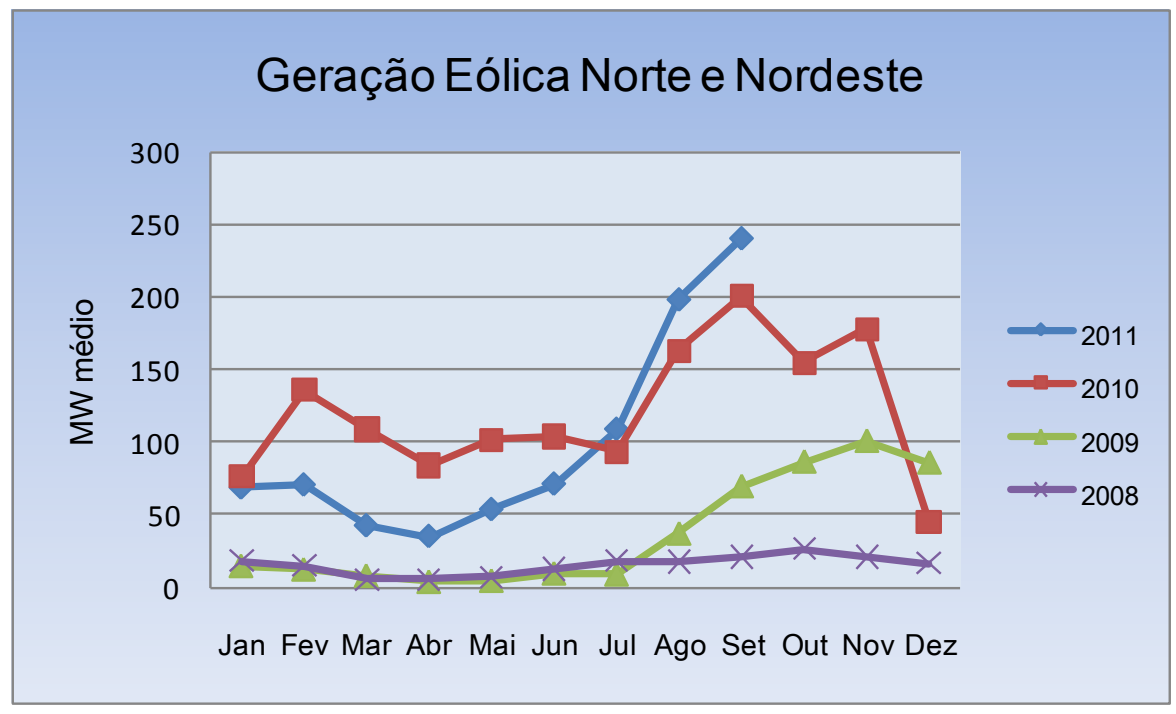

Gráfico 11: Gráfico de Geração de Energia Eólica - Norte e Nordeste. Fonte: Elaboração a partir de informações do ONS (www.ons.org.br)

Já as regiões Sul, Sudeste e Centro Oeste, apresentaram crescimento da geração eólica no ano de 2011, conforme comprovado por meio de informações de geração do ONS.

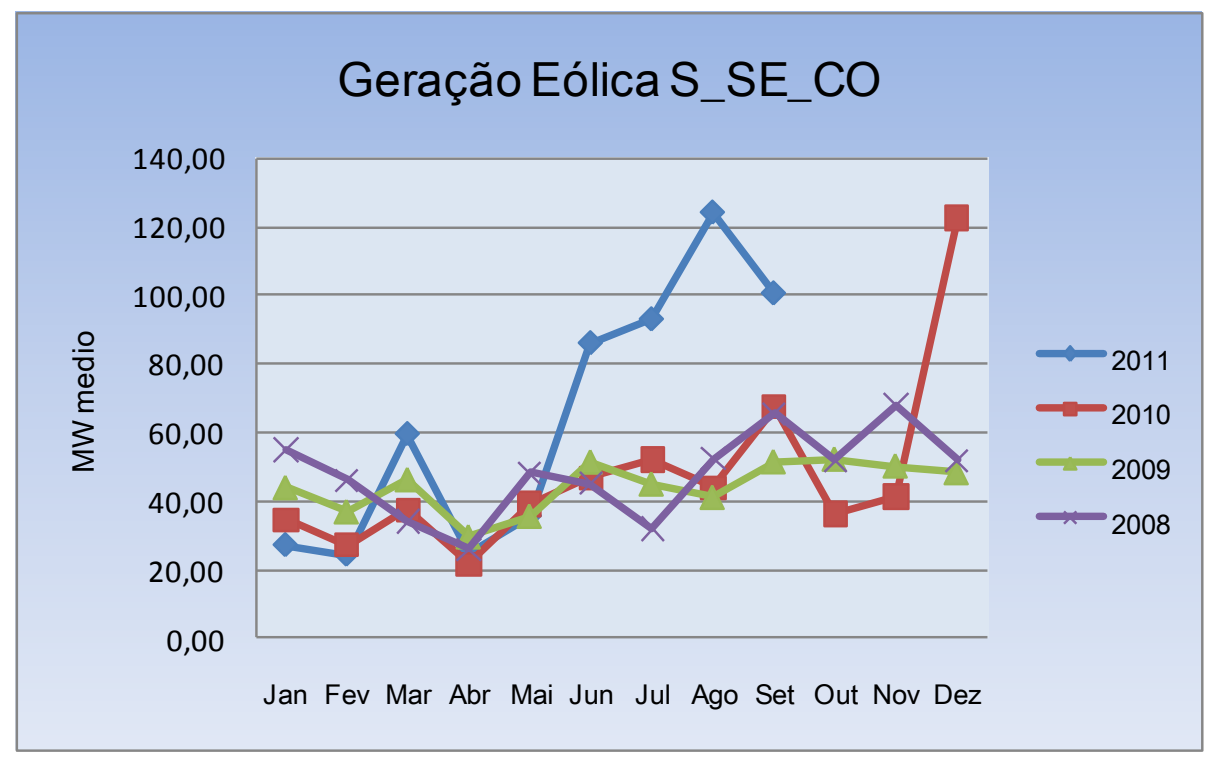

Gráfico 12: Gráfico de Geração de Energia Eólica - S_SE_CO.

Fonte: Elaboração a partir de informações do ONS (www.ons.org.br).

Importante acrescentar ainda que a medição dos ventos é uma barreira identificada na geração eólica. 
O setor não possui histórico de dados e alterações climáticas e variações na intensidade do fluxo dos ventos, que pode impactar as tensões na rede elétrica, prejudicando a geração de energia eólica.

\subsection{Análise de Complementaridade de geração entre fontes renováveis de produção sazonal - Geração de Energia Eólica e Termelétricas movidas a Biomassa com PCH's}

Inicialmente, cabe destacar o fato de que, como energia de reserva, a biomassa de cana de açúcar e a energia eólica podem atuar de forma complementar à geração hidrelétrica. O período de safra de cana de açúcar coincide com o período seco do sistema elétrico, quando os reservatórios estão normalmente deplecionados e a produção hidrelétrica é menor, como também a fonte eólica, pode apresentar complementação importante, pelo fato de que, no período seco anual há mais vento. Assim, a entrada dessas usinas traz um impacto benéfico relevante na formação do Preço da Liquidação das Diferenças (PLD), que é extremamente sensível ao nível dos reservatórios, contribuindo também para a mitigação do risco de atendimento sistêmico.

Por outro lado, na ótica empresarial, a complementariedade existente entre fontes incentivadas de produção sazonal, pode ser utilizada para permitir aos agentes atuando no mercado livre, maximizar sua receita esperada, sob condicionamento de critérios de risco pré-fixados. Destarte, com o objetivo de avaliar e qualificar a sinergia entre energia eólica e da biomassa que tem perfil de produção complementar às Pequenas Centrais Hidrelétricas $(\mathrm{PCH}$ 's), foram realizadas simulações para identificar a melhor estratégia de contratação de energia, a fim de buscar a máxima receita líquida possível, atendendo restrições de risco, conforme se detalha a seguir.

Para essa análise foram utilizados dados já trabalhados anteriormente [11] e [38], acrescidos de dados de geração de energia eólica (ONS) do perfil nordeste. Dito isto, foram comparadas situações que consideram (i) um agente incentivado atuando comercialmente isolado e (ii) mais de um agente incentivado atuando comercialmente de forma conjunta (portfólio de plantas de um único agente gerador), de modo a perseguir a vantagem de produção sazonal complementar, em 
que os agentes proporcionam hedge ${ }^{23}$ entre si. Nessa situação, torna-se possível maximizar a receita do conjunto, sem infração aos critérios de risco, obtendo ganhos em relação à soma das receitas dos agentes quando considerados atuando isoladamente.

Para um período de 5 anos, os critérios de risco financeiro fixados, para todas as simulações apresentadas, foram (i) limite de 3\% de tolerância de receita abaixo de $80 \%$ de uma receita constituída pela receita de contratos de longo prazo de contratação de $100 \%$ da Garantia Física e (ii) limite de $3 \%$ de probabilidade de ocorrência de receitas entre $80 \%$ e $85 \%$ da mesma receita de referência descrita em (i). Por simplicidade de apresentação dos resultados, foi assumido um perfil "flat" para os contratos bilaterais em todos os casos estudados.

Para a configuração simulada no modelo NEWAVE, obteve-se PLD médio de R\$ 140,66

\subsubsection{Simulações: Parte I}

\subsubsection{Simulação I: Análise de uma PCH (a) operando comercialmente de forma isolada}

Registradas as restrições, em primeiro lugar foi analisada uma $\mathrm{PCH}$ com as seguintes características: potência instalada de $30 \mathrm{MW}$, subsistema Sudeste e preço de venda em contratos a $\mathrm{R} \$ 150,00 / \mathrm{MWh}$.

Operando sozinha, esta PCH possui Garantia Física (GF) de 17,52 MW médios, sendo possível alocar $89,83 \%$ em contratos. Observe-se do gráfico a seguir, que se não houvesse a limitação de risco financeiro, a maximização de receita seria obtida com a contratação de $100 \%$ do lastro físico da PCH. A Receita Total no período de 5 (cinco) anos será $\mathrm{R} \$ 120.604 .845,71$.

\footnotetext{
${ }^{23}$ Mecanismo de 'hedge' caracteriza um mecanismo de proteção para as flutuações do Preço de Curto Prazo (PLD).
} 


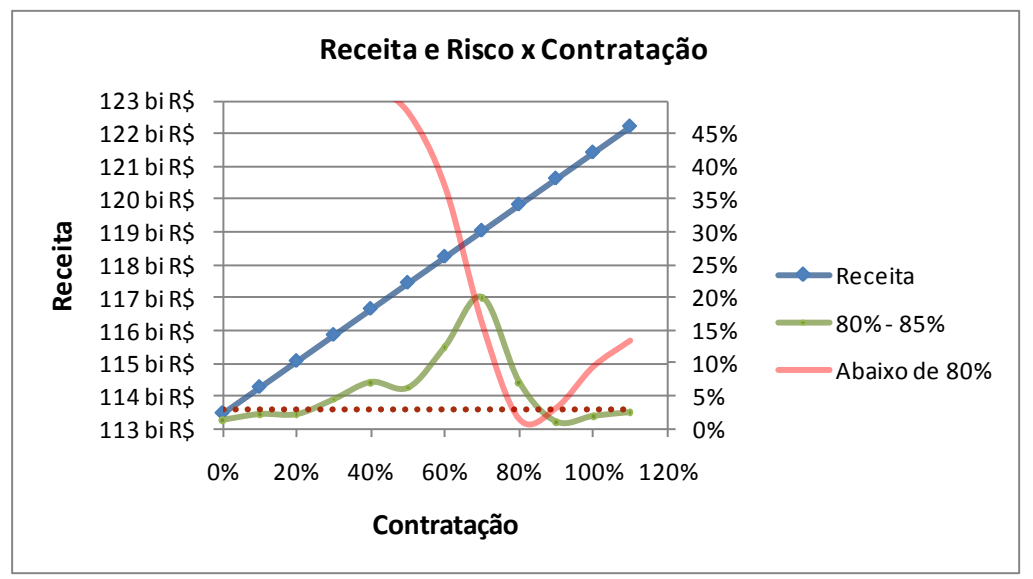

Gráfico 13: Análise de uma PCH (a) operando comercialmente de forma isolada, com preço de venda a R\$ 150,00/MWh.

Fonte: Elaboração a partir da simulação realizada em planilha Excel, com base de dados já trabalhados em [11].

Verifica-se, da simulação, que a melhor estratégia identificada para atendimento às restrições, apresentadas no início dessa seção, e ao mesmo tempo maximizar a receita, é disponibilizar $89.83 \%$ da garantia física da $\mathrm{PCH}$ sob contrato e disponibilizar o restante para ser vendido ao preço spot. Nota-se, do gráfico, que aumentar o percentual de contratação, implica em violar a restrição de receita mínima abaixo de $80 \%$ da receita de referência.

\subsubsection{Simulação II: Análise de uma Usina Eólica (b) operando comercialmente de forma isolada}

Análise de uma usina eólica com potência instalada de $30 \mathrm{MW}$, perfil de geração do subsistema nordeste e preço de venda em contratos a $\mathrm{R} \$ 150,00 / \mathrm{MWh}$.

Operando sozinha, esta usina eólica possui Garantia Física (GF) de 6,74 MW médios, sendo utilizados $100 \%$ em contratos. A Receita Total maximizando período de 5 (cinco) anos foi $\mathrm{R} \$ 44.888 .012,68$.

Verifica-se neste caso, que mesmo com as restrições de risco impostas, foi possível disponibilizar $100 \%$ da Garantia Física da planta em contratos bilaterais. 


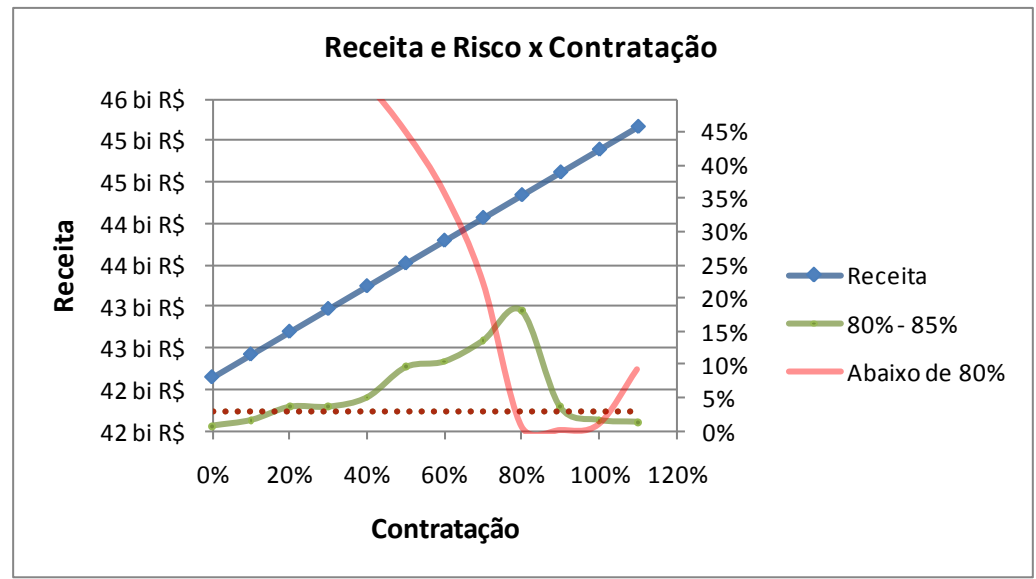

Gráfico 14: Análise de uma usina eólica (b) operando comercialmente de forma isolada, com preço de venda a $\mathrm{R} \$ 150,00 / \mathrm{MWh}$.

Fonte: Elaboração a partir da simulação realizada em planilha Excel, com base de dados já trabalhados em [11].

\subsubsection{Simulação III: Análise da PCH (a) e a Usina Eólica (b) operando comercialmente em conjunto}

Realizada a simulação conjunta da $\mathrm{PCH}$ com a usina eólica apresentados nas simulações I e II, operando como uma única empresa, verifica-se que é possível alocar $94,4 \%$ da Garantia Física do conjunto (soma das Garantias Físicas Individuais) em contratos bilaterais de longo prazo.

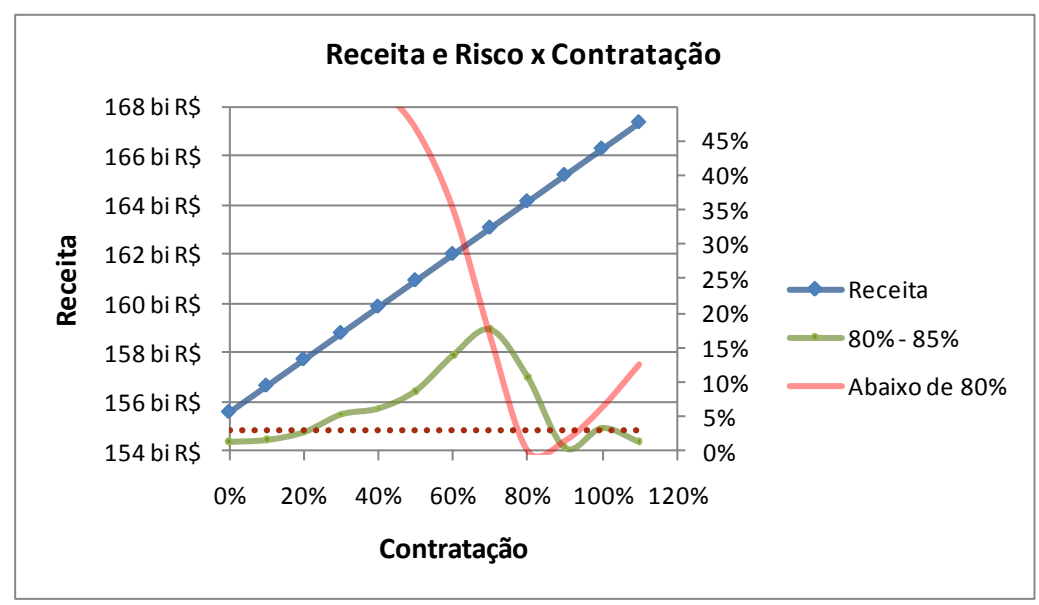

Gráfico 15: Análise de complementação eólica (b) e PCH (a), operando comercialmente em conjunto, com preço de venda a $\mathrm{R} \$ 150,00$.

Fonte: Elaboração própria a partir da simulação realizada em planilha Excel, com base de dados já trabalhados em [11].

A Receita Total maximizada no período de 5 (cinco) anos foi $\mathrm{R} \$ 165.711 .721,52$. 
Verifica-se que a Receita Total no período de 5 (anos) da estratégia de venda das duas plantas em conjunto supera a soma das receitas maximizadas das mesmas plantas quando individualmente consideradas, com um ganho de $\mathrm{R} \$ 218.862,13$. Conclui-se, portanto, que a melhor estratégia identificada para atendimento às restrições, conforme apresentadas no início da seção, é alocar $94,40 \%$ da Garantia Física total em contratos bilaterais e disponibilizar o restante para ser vendido no mercado spot.

\subsubsection{Simulação IV: Análise de Usina termelétrica a Biomassa (c) operando comercialmente de forma isolada}

Foram avaliados também os ganhos de complementação entre uma térmica a biomassa (c) e a PCH (a) analisada anteriormente na simulação I.

Feita a simulação para obtenção da melhor estratégia de contratação da térmica a biomassa, também com potência instalada de $30 \mathrm{MW}$, considerando as mesmas restrições, verifica-se que não existe solução factível. Isso ocorre porque ao atender um contrato "flat", a planta a biomassa se expõe de modo excessivo ao período úmido, quando não produz. Por outro lado, ao deixar grande parte de sua Garantia Física sem alocação em contrato, a receita resulta muito baixa em período de hidrologia favorável (que ocorrem 95\% do tempo), inviabilizando se obter um "tradeoff" para acomodar as restrições de risco financeiro.

\subsubsection{Simulação V: Análise da $\mathrm{PCH}$ (a) e a Usina termelétrica à Biomassa (c) operando em conjunto}

Avaliando a seguir a performance do conjunto formado por essa térmica a biomassa

e a $\mathrm{PCH}$ analisada anteriormente, verifica-se os comportamentos e risco estampados no gráfico a seguir. 


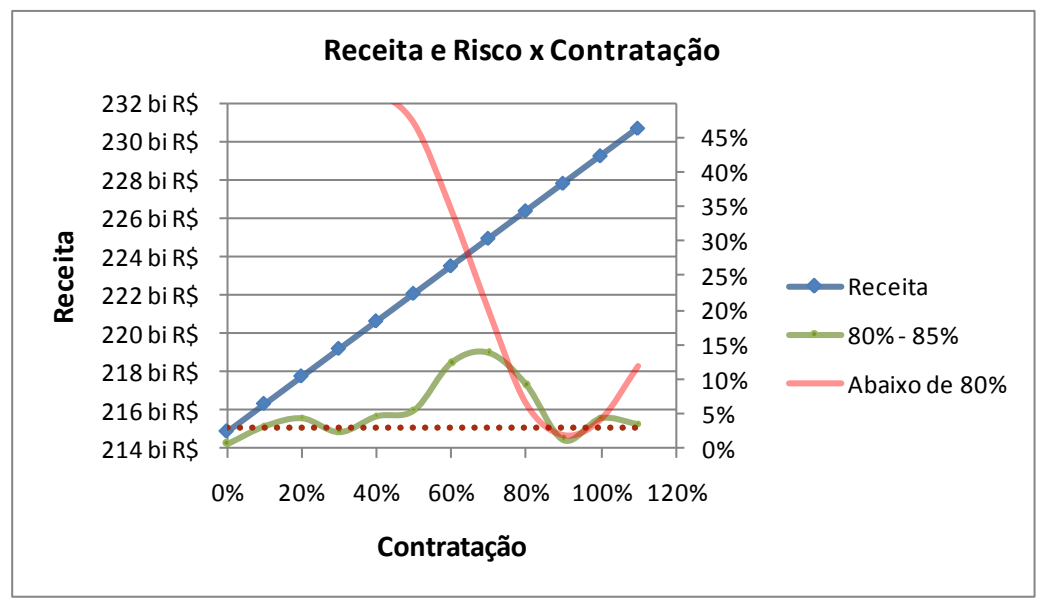

Gráfico 16: Análise de complementação térmica a biomassa (c) e PCH (a), operando comercialmente em conjunto, com preço de venda a $\mathrm{R} \$ 150,00$.

Fonte: Elaboração própria a partir da simulação realizada em planilha Excel, com base de dados já trabalhados em [11].

A Garantia Física possível de alocar em contratos, para o conjunto é $94,90 \%$. A Receita Total maximizada no período de 5 (cinco) anos será $\mathrm{R} \$ 228.516 .925,60$. Cabe observar que, para os critérios de risco admissível considerados na simulação, a usina térmica a biomassa, quando operando de forma isolada, se apresentou inviável.

Conclui-se neste caso, que a complementação da usina a biomassa à $\mathrm{PCH}$, se mostrou muito vantajosa, tendo em vista a inviabilidade da comercialização isolada da planta de cogeração.

\subsubsection{Simulações I a V:}

Verifica-se ainda em todas as simulações apresentadas nesse item que quanto maior a venda em contratos, maior é a receita, em razão de que o preço da venda é $R \$ 150,00$ comparado à média do PLD que é igual a $R \$ 140,66$.

\subsubsection{Simulações: Parte II}

Nas simulações da parte II, foram considerados os mesmo casos simulados na parte I, porém agora com preço de venda a R $\$ 130,00 / \mathrm{MWh}$. 


\subsubsection{Simulação l': Análise da PCH (a) operando comercialmente de forma isolada}

Como análise de sensibilidade das conclusões ao valor do preço de contrato, considerando os mesmos casos simulados na parte I, para a $\mathrm{PCH}$ (a) operando comercialmente de forma isolada, com preço de venda a $\mathrm{R} \$ 130,00 / \mathrm{MWh}$, foram obtidos os resultados conforme verifica-se no gráfico a seguir:

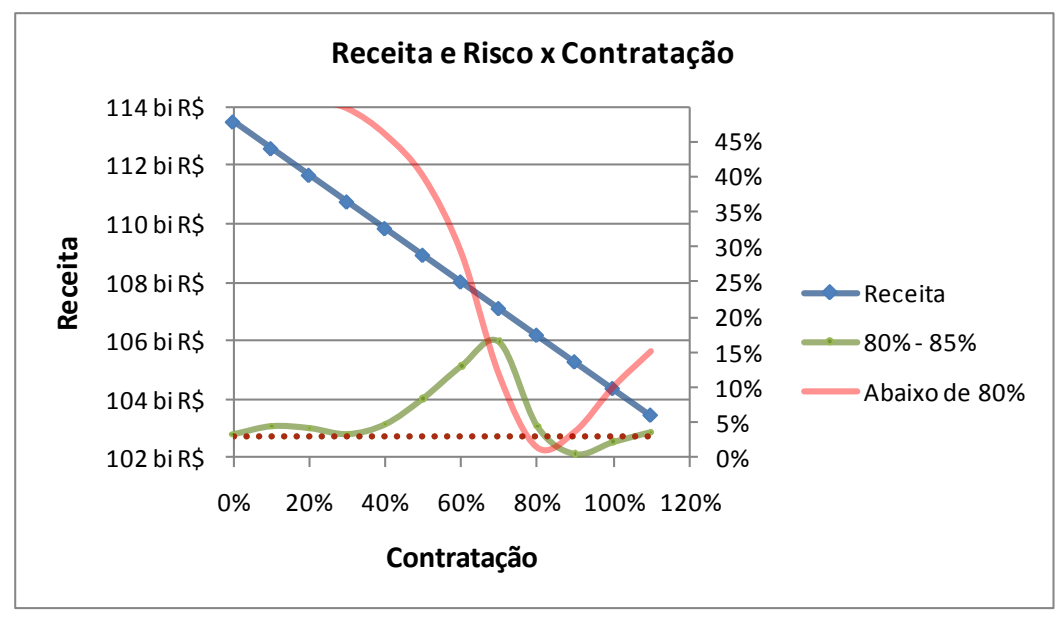

Gráfico 17: Análise de uma usina eólica (b) operando comercialmente de forma isolada, com preço de venda a R\$130,00/MWh.

Fonte: Elaboração a partir da simulação realizada em planilha Excel, com base de dados já trabalhados em [11].

$\mathrm{Na}$ nova conjuntura de preços de venda, quando operando sozinha, foi possível alocar $80,97 \%$ da Garantia Física (GF) da PCH em contratos. A Receita Total maximizada no período de 5 (cinco) anos será $R \$ 106.069 .072,68$. Note-se que agora, a maximização da receita, sem ponderar restrições, seria obtida alocando-se toda a Garantia Física da planta no mercado spot.

\subsubsection{Simulação II': Análise da Usina Eólica (b) operando individualmente}

Agora, se analisa a mesma usina eólica anterior (b) e características (potência instalada de $30 \mathrm{MW}$, perfil de geração do subsistema nordeste), porém com preço de venda em contratos a $\mathrm{R} \$ 130,00 / \mathrm{MWh}$. 


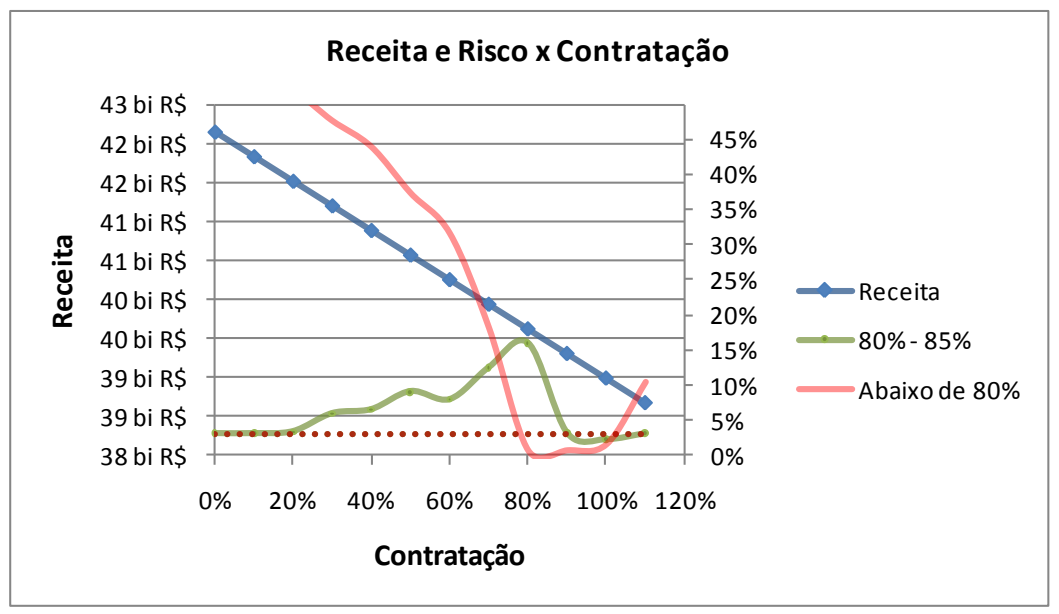

Gráfico 18: Análise de uma usina eólica (b) operando comercialmente de forma isolada, com preço de venda a R\$130,00/MWh.

Fonte: Elaboração a partir da simulação realizada em planilha Excel, com base de dados já trabalhados em [11].

No caso da planta eólica, quando comercializando energia individualmente, foi necessário alocar $92,67 \%$ da Garantia Física em contratos. A Receita Total maximizada no período de 5 (cinco) anos será $\mathrm{R} \$ 39.214 .553,92$.

Lembre-se que na simulação II anterior, verificou-se que para essa mesma usina ao vender energia a R $\$ 150,00 / \mathrm{MWh}$, a melhor estratégia comercial foi vender $100 \%$ da Garantia Física por meio de contratos.

\subsubsection{Simulação IIl': Análise da PCH (a) e a Usina Eólica (b) operando em conjunto}

Realizada a simulação conjunta da PCH (a) operando comercialmente em conjunto com a usina eólica (b), com preço de venda a $R \$ 130,00 / \mathrm{MWh}$, conforme apresentadas anteriormente nas simulações l' e Il', o resultado está apresentado no gráfico a seguir. 


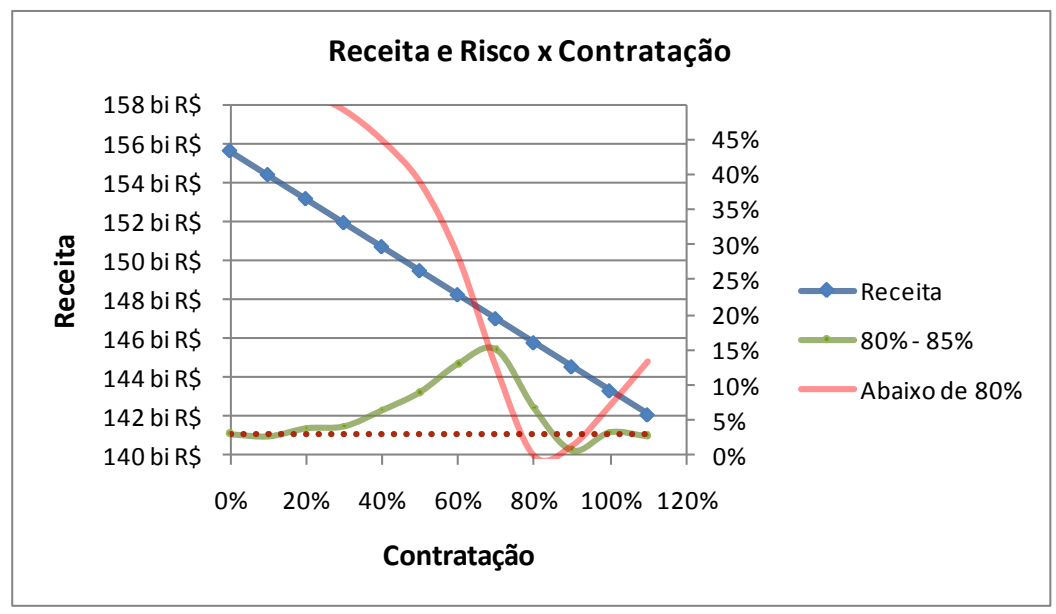

Gráfico 19: Análise de complementação eólica (b) e PCH (a), operando em conjunto, com preço de venda a $\mathrm{R} \$ 130,00$.

Fonte: Elaboração própria a partir da simulação realizada em planilha Excel, com base de dados já trabalhados em [11].

Como resultado da simulação, a melhor estratégia foi de alocar $81,46 \%$ da Garantia Física em contratos. A Receita Total maximizada no período de 5 (cinco) anos é R\$ 145.593.676,29.

Verifica-se que a Receita Total no período de 5 (anos) da estratégia de venda da usina eólica que complementou a geração da $\mathrm{PCH}$ será maior, ou seja, com um ganho de $\mathrm{R} \$ 310.049,69$.

Em comparação à análise anterior, simulada com preço de venda a $R \$ 150,00 / M W h$, a melhor estratégia foi alocar $94,40 \%$ da Garantia Física em contratos bilaterais.

\subsubsection{Simulação IV': Análise da Usina a Biomassa (c)}

Analisando novamente a contratação de uma termelétrica a biomassa, com as mesmas configurações da simulação IV, realizada anteriormente, porém com preço de venda em contratos a $R \$ 130,00$, verifica-se novamente que não houve viabilidade para sua implementação. 


\subsubsection{Simulação V': Análise da PCH (a) e a Usina termelétrica a Biomassa (c) operando em conjunto}

Observe ainda a seguir, que após a análise da complementação da termelétrica a biomassa (c) à $\mathrm{PCH}$ (a) analisada anteriormente, porém com preço de venda em contratos a $R \$ 130,00$, obtém-se os resultados estampados no gráfico, a seguir:

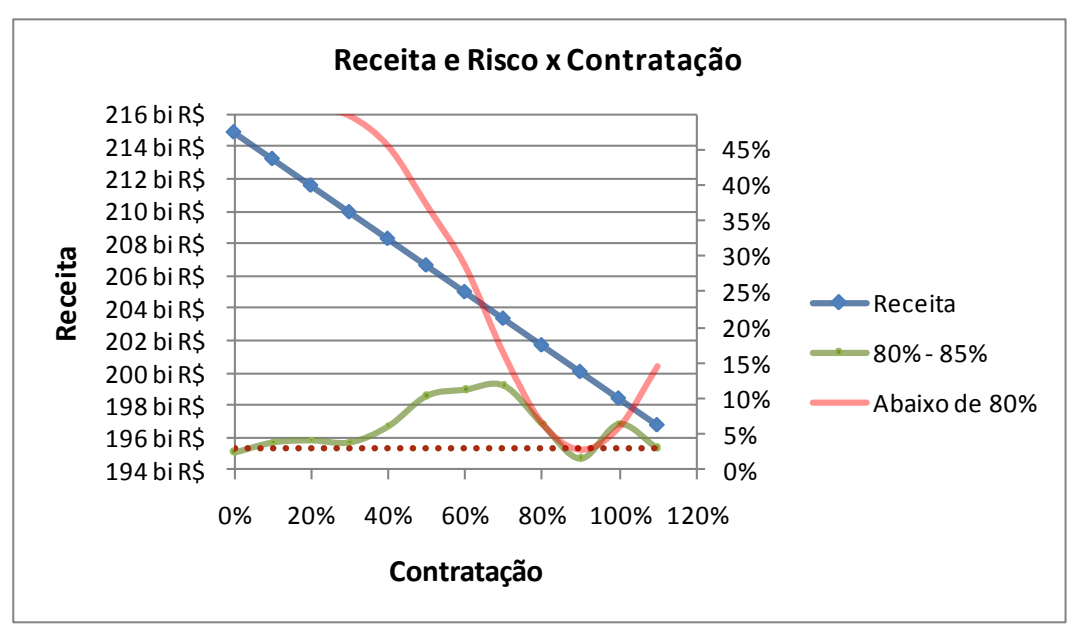

Gráfico 20: Análise de complementação termelétrica a biomassa (c) e PCH (a), operando em conjunto, com preço de venda a $\mathrm{R} \$ 130,00 / \mathrm{MWh}$.

Fonte: Elaboração própria a partir da simulação realizada em planilha Excel, com base de dados já trabalhados em [11].

Após a realização da simulação conjunta, verifica-se a necessidade de alocação de $88,11 \%$ da Garantia Física em contratos. A Receita Total maximizada no período de 5 (cinco) anos foi $\mathrm{R} \$ 200.334 .108,60$.

Conclui-se neste caso que a complementação da usina termelétrica a biomassa à $\mathrm{PCH}$, novamente se mostrou muito vantajosa, tendo em vista a inviabilidade de comercialização da planta de cogeração para atendimento de contratos "flat" quando operando de forma isolada.

\subsubsection{Simulações l' a V':}

Verifica-se ainda nas simulações com preço de venda de $R \$ 130,00 / \mathrm{MWh}$, que quanto menor a venda em contratos, maior é a receita, em razão de que o preço da venda é $R \$ 130,00$ comparado à média do PLD que é igual a $R$ \$140,66. 


\section{CONCLUSÃo}

Pode-se dizer que os aspectos regulatórios, de comercialização e aplicação das fontes incentivadas estão diretamente relacionados à sustentabilidade garantindo assim a expansão da oferta de energia elétrica, adicionais à hidroeletricidade, de forma a atingir um desenvolvimento energético mais sustentável.

A Resolução Normativa $n^{\circ}$ 247/2006 estabeleceu as condições para a comercialização de energia elétrica incentivada. $\mathrm{O}$ crescimento do mercado livre por meio da comercialização de energia incentivada é um importante fator da inserção das fontes alternativas renováveis e possui papel importante na expansão da oferta de eletricidade no Brasil. Destacando-se nesse ambiente a energia proveniente de $\mathrm{PCH}$ 's, empreendimentos eólicos e as térmicas a biomassa (fontes consideradas incentivadas), sendo um aspecto relevante dessa regulamentação a criação de um nicho de mercado específico para as fontes incentivadas, constituído pelos consumidores com demanda contratada entre $500 \mathrm{~kW}$ e $3.000 \mathrm{~kW}$, os quais podem migrar para o mercado livre apenas e tão somente se adquirirem sua energia das referidas fontes incentivadas.

Verificou-se que no período de fevereiro de 2010 a outubro de 2011, a quantidade de consumidores especiais cresceu de forma considerável, superando o número de consumidores livres, ou seja, o número de consumidores especiais cresceu $116,6 \%$, enquanto que o número de consumidores livres cresceu apenas $11,21 \%$.

Destaca-se ainda, na comercialização de energia incentivada, um estímulo adicional para todos os agentes envolvidos na compra e venda de energia proveniente de fontes incentivadas, ou seja, o direito ao desconto sobre as Tarifas de Uso dos Sistemas de Distribuição (TUSD) ou Tarifas de Uso dos Sistemas de Transmissão (TUST). Os agentes compradores de energia incentivada também recebem o desconto nas referidas tarifas como reflexo do agente vendedor, abrindo espaço para que as Fontes Alternativas possam se apresentar mais competitivas. 
Outro aspecto contemplado refere-se ao fato de que, como energia de reserva, a biomassa de cana de açúcar e a energia eólica podem atuar de forma complementar à geração hidrelétrica. O período de safra da cana de açúcar coincide com o período seco do sistema elétrico, quando os reservatórios estão normalmente deplecionados, como também a fonte eólica, pelo fato de que, no período seco anual, há mais vento. Assim, a entrada dessas usinas traz um impacto benéfico importante na formação do Preço de Liquidação das Diferenças, que é extremamente sensível ao nível dos reservatórios, contribuindo também para a mitigação do risco de atendimento sistêmico.

As principais vantagens da energia eólica em relação às fontes térmicas derivam dos aspectos ambientais, pois além de ser limpa e renovável, apresenta qualidades com a complementariedade com o regime hidrológico principalmente na região nordeste brasileira, onde o potencial de energia eólica é alto e por isso se tem perspectivas concretas de exportação de energia para outras áreas do país.

A sinergia existente entre as fontes eólica e biomassa e a geração hidrelétrica é discutida. Nesse âmbito, incluiu-se uma aferição do risco de comercialização da Energia Incentivada e como esse risco pode ser mitigado através de "hedge" contratual entre fontes incentivadas. Dito isto, com o objetivo de avaliar e qualificar a sinergia entre energia eólica e da biomassa que tem perfil de produção complementar às Pequenas Centrais Hidrelétricas ( $\mathrm{PCH}$ 's), foram realizadas simulações para identificar a melhor estratégia de contratação de energia, a fim de buscar a máxima receita líquida possível, atendendo restrições de risco.

Como consequência da análise de complementação energética entre as usinas eólicas e termelétricas a biomassa às $\mathrm{PCH}$ 's, foi verificada a existência de um mecanismo de "hedge" financeiro natural entre fontes incentivadas com forte variação de produção sazonal, de tal forma que quando duas usinas comercializam energia em conjunto ( $\mathrm{PCH}+$ eólica) ou ( $\mathrm{PCH}+$ termelétrica a biomassa), obtém-se um retorno financeiro maior do que quando a comercialização é realizada de forma isolada. 
Sugere-se para trabalhos futuros, realização de novas simulações, de tal forma que usinas eólicas e termelétricas a biomassa comercializem energia em conjunto com PCH's, em diversas proporções, a fim de buscar a máxima receita líquida possível, atendendo restrições de risco.

Com relação à geração de energia, verificou-se ainda que a Geração Distribuída também pode ser considerada como fonte complementar à geração hidrelétrica, quando se tratar de geração termelétrica a biomassa a cana de açúcar. Nota-se ainda, a criação de um ambiente especial para o desenvolvimento de um mercado para a geração distribuída com energias renováveis.

A regulação do setor elétrico é um importante aspecto a ser considerado para caracterizar o efetivo aproveitamento dessas fontes alternativas de energia, ajudando o país a atingir um desenvolvimento mais sustentável.

Diversos são os estudos realizados pelos órgãos e associações do setor elétricos que comprovam o crescimento da aplicação das fontes alternativas consideradas incentivadas, proporcionando benefícios energéticos e evitando a emissão de gases efeito estufa.

Destaca-se que o próprio PROINFA em sua regulamentação, com o Decreto $n^{\circ}$ $5.025 / 2004$ já possui a prerrogativa de redução da emissão de gases de efeito estufa, nos termos da Convenção-Quadro das Nações Unidas sobre Mudanças do Clima, contribuindo para o desenvolvimento sustentável.

Ainda, o incentivo à Energia Incentivada pode ser considerado um relevante fator na redução nos níveis de emissões no setor elétrico, ajudando o país a atingir um desenvolvimento mais sustentável. Nessa perspectiva, foram apresentados resultados de estudos do setor elétrico, realizado pelas instituições do setor elétrico e outros órgãos, que comprovam o crescimento das fontes alternativas de energia, eólica, biomassa e PCH's na matriz energética brasileira que consequentemente proporcionam benefícios energéticos relacionados à segurança do abastecimento evitando ainda a emissão de gases de efeito estufa. 
Em que pese o fato de que as propostas regulatórias e comerciais apresentadas ainda estão sendo discutidas no setor elétrico, e portanto, não se dispõe de um encaminhamento definitivo, vale a pena considerar seu entendimento em razão de seus impactos relevantes no que diz respeito à comercialização de energia incentivada. Destaca-se no trabalho a possibilidade de cessão de energia excedente pelos consumidores livres e especiais; a criação de penalidades por alavancagem; a proposta de criação do Comercializador Varejista; como também dos certificados de energia (CEE's).

Como última consideração, mesmo não sendo objetivo desse trabalho, por ter data de corte de atualização de informações até junho de 2012, vale a pena registrar a Medida Provisória 579, de 11 de setembro de 2012 que dispõe sobre a redução dos encargos do setor elétrico e também estabelece prazo de retorno de cinco anos ao mercado cativo para consumidores especiais. Mesmo não sendo realizada uma análise a respeito dessa MP pode-se verificar que tais alterações podem afetar o mercado de consumo de energia renovável e que atualmente já existe uma movimentação dos consumidores de energia especial no sentido de retorno ao mercado cativo. 


\section{REFERÊNCIAS BIBLIOGRÁFICAS}

\subsection{Documentos}

[1] Januário, A.C.V. - O mercado de Energia Elétrica de Fontes Incentivadas: Proposta para sua expansão e implicações na Câmara de Comercialização de Energia Elétrica. Dissertação (Mestrado em Energia Elétrica) - Escola Politécnica da universidade de São Paulo. São Paulo, 2007.

[2] MMA - Ministério do Meio Ambiente. Plano Nacional sobre Mudança do Clima - PNMC - Brasil. Brasília, dezembro de 2008. Disponível em http://www.mma.gov.br/sitio/index.php?ido=publicacao.publicacoesPorSecretaria\&id Estrutura=137, acesso em 06.07.2010.

[3] Esparta, ARJ. - Redução de emissões de gases de feito estufa no setor Elétrico brasileiro: a experiência do Mecanismo de Desenvolvimento Limpo do Protocolo de Quioto. Tese de Doutorado, São Paulo, Programa Interunidades de Pós-Graduação em Energia, Universidade de São Paulo, 2008.

[4] Duke Energy - Guia do Cliente Livre. 1 Edição, Maio de 2006.

[5] CCEE - Câmara de Comercialização de Energia Elétrica. Regras e Procedimentos de Comercialização de Energia Elétrica. http://www.ccee.org.br. Acesso em 2011.

[6] CCEE - Câmara de Comercialização de Energia Elétrica. Treinamento de Energia Incentivada. http://www.ccee.org.br. Acesso em 2011.

[7] EPE- Empresa de Pesquisa Energética. Plano Decenal de Expansão de Energia Elétrica 2020. Disponível em http://www.epe.gov.br, acesso em 20.10.2011.

[8] ANEEL - Agência Nacional de Energia Elétrica. Relatório ANEEL 10 anos. Disponivel em http://www.aneel.gov.br/arquivos/PDF/Aneel_10_Anos.pdf , acesso em 15.04.11.'

[9] ONS - Operador Nacional do Sistema Elétrico. http://www.ons.org.br. Acesso em 2011. 
[10] Silva, E.F. e Ramos, D.S. - A Comercialização de Energia Incentivada no Brasil. São Paulo, 2008.

[11] Dias, N.V. - Estratégias de energia para um portfólio de usinas: Análise da complementariedade Energética e Mecanismo de "Hedge". Projeto de Formatura da Escola Politécnica da USP, São Paulo, 2008.

[12] EPE - Empresa de Pesquisa Energética. Expansão da Geração Eólica no Brasil. Rio de Janeiro, fevereiro de 2009. Disponível em http://www.epe.gov.br, acesso em 01.08.2011.

[13] Ricosti, J.F.C. - Inserção da energia eólica no sistema hidrotérmico brasileiro. Dissertação (Mestrado em Energia Elétrica) - Escola Politécnica da universidade de São Paulo. São Paulo, 2011.

[14] da Silva, E.F. - Principais Condicionantes das Alterações no Modelo de Comercialização de Energia Elétrica: Retrospectiva e Análise CríticaDissertação (Mestrado em Energia Elétrica) - Escola Politécnica da universidade de São Paulo. São Paulo, 2008.

[15] Escola Politécnica da Universidade de São Paulo - Diretrizes para apresentação de dissertações e teses / Divisão de Biblioteca da Epusp, - 3. ed. São Paulo, 2006.

[16] CCEE - Câmara de Comercialização de Energia Elétrica. Visão Geral das Operações na CCEE. http://www.ccee.org.br.

[17] ABIAPE, ABRACEEL, ABRACE, ANACE, APMPE e APINE. 0 Desenvolvimento do ACL - Questões e Soluções. São Paulo, 2010

[18] ANEEL - Agência Nacional de Energia Elétrica. Nota Técnica n 123/2010SEM/ANEEL.

http://www.aneel.gov.br/aplicacoes/audiencia/dspListaDetalhe.cfm?attAnoAud=2010 \&attldeFasAud=516\&id_area=13\&attAnoFasAud=2011. Acesso em 2011.

[19] ANEEL - Agência Nacional de Energia Elétrica. Audiência Pública 123/2010 Obter subsídios e informações adicionais para promover aprimoramentos em disposições relativas à apuração de insuficiência de lastro/cobertura 
contratual, e instituir a penalidade por violação de limite máximo de alavancagem. Disponível

http://www.aneel.gov.br/aplicacoes/audiencia/dspListaDetalhe.cfm?attAnoAud=2010 \&attldeFasAud=516\&id_area=13\&attAnoFasAud=2011. Acesso em 2011.

[20] ANEEL - Agência Nacional de Energia Elétrica. Audiência Pública 39/2011 Obter subsídios à elaboração de ato regulamentar para aprovação do segundo conjunto de módulos das Regras de Comercialização aplicáveis ao Novo Sistema de Contabilização e Liquidação - Novo SCL. Disponível em http://www.aneel.gov.br/aplicacoes/audiencia/dspListaDetalhe.cfm?attAnoAud=2011 \&attldeFasAud=557\&id_area=13\&attAnoFasAud=2011. Acesso em 2011.

[21] ANEEL - Agência Nacional de Energia Elétrica. Audiência Pública 29/2010 Obter subsídios e informações para elaboração de ato regulamentar, a ser expedido pela ANEEL, para aprovação de Módulos das Regras de Comercialização aplicáveis ao Novo Sistema de Contabilização e Liquidação $\begin{array}{lllll}\text { Financeira } & \text { - } & \text { Novo } & \text { SCL. } & \text { Disponível }\end{array}$ http://www.aneel.gov.br/aplicacoes/audiencia/dspListaDetalhe.cfm?attAnoAud=2011 \&attldeFasAud=557\&id_area=13\&attAnoFasAud=2011. Acesso em 2011.

[22] APINE - Associação Brasileira dos Produtores Independentes de Energia Elétrica. Nota Técnica Apine N.008/2008. Formatação de Leilões para Usinas Eólicas. Dezembro de 2008.

[23] EPE - Empresa de Pesquisa Energética. Metodologia de Cálculo da Garantia Física da Usinas. Julho de 2008. Disponível em http://www.epe.gov.br, acesso em 01.08.2011.

[24] EPE - Empresa de Pesquisa Energética. $1^{\circ}$ Leilão de Energia de Reserva 2008. Definição do Preço Inicial. Junho de 2008. Disponível em http://www.epe.gov.br, acesso em 01.08.2011.

[25] EPE - Empresa de Pesquisa Energética. Estudos para Expansão da Geração. Metodologia de Contabilização da Produção Eólica. Junho de 2009. Disponível em http://www.epe.gov.br, acesso em 01.08.2011. 
[26] EPE - Empresa de Pesquisa Energética. Informe Técnico $\mathbf{N}^{\circ}$ EPE-DEEIT002/2009-r0. Regras de Contabilização da Produção da Energia Eólica. Março de 2009. Disponível em http://www.epe.gov.br, acesso em 01.08.2011.

[27] CEPEL - Centro de Pesquisas de Energia Elétrica. Atlas do Potencial Eólico Brasileiro. $\quad$ Brasília, $2001 . \quad$ Disponível em http://www.cresesb.cepel.br/publicacoes/index.php?task=livro\&cid=1, acesso em 13.10.2011.

[28] Barros, P.V. - Análise de Estratégias de Comercialização de Energia para Pequenas Centrais Hidrelétricas no Novo Ambiente Institucional do Setor Elétrico. Projeto de Formatura da Escola Politécnica da USP, São Paulo, 2007.

[29] Jadjiski, D. - Geração Distribuída: direto na rede. Reportagem Especial. Disponível em http://canalenergia.com.br/zpublisher/materias/Reportagem_Especial.asp?id=76798. Acesso em 06.04.2011.

[30] Tatemoto, K.A. e Ramos, D.S. - Energia Incentivada: uma discussão focada na complexidade da regulação e seus rebatimentos na comercialização. CLAGTEE - IX Latin - American Electricity Generation and Transmission Congress. Mar del Plata - Argentina, 2011.

[31] PEA 5011 - "Métodos de quantificação de créditos de carbono no setor elétrico brasileiro utilizando-se os Mecanismos de Protocolo de Quioto" - Prof. Dr. Fernando Amaral de Almeida Prado Jr e Prof. Livre Docente Marco António Saidel. Escola Politécnica da Universidade de São Paulo, 2009.

[32] MME- Ministério de Minas e Energia. Resenha Energética Brasileira. Exercício de 2010 (Preliminar). Maio de 2011. Disponível em http://www.mme.gov.br, acesso em 20.10.2011.

[33] EPE - Empresa de Pesquisa Energética. Balanço Energético Nacional 2011 Ano Base 2010. Brasília, 2011. Disponível em http://www.epe.gov.br/Estudos/Paginas/Balan\%C3\%A70\%20Energ\%C3\%A9tico\%20 Nacional\%20\%E2\%80\%93\%20BEN/Estudos_13.aspx, acesso em 03.11.2011. 
[34] EPE - Empresa de Pesquisa Energética. Custo Marginal de Expansão Metodologia de Cálculo 2011. No EPE-DEE-RE-091/2011-r0. Outubro de 2009. Disponível em http://www.epe.gov.br/geracao/Documents/Estudos_26/NT_MetodologiadeCalculoC ME_2011.pdf. Acesso em 09.11.2011.

[35] Christofari, V.D. O setor de energia elétrica: aspectos físicos e regulamentação. Curso Ministrado pela Triconsult - estudos e Projetos Ltda. Ano 2007. São Paulo.

[36] PEA 5916 e PEA 5917 - "Formação de Preços e Comercialização no Mercado de Energia Elétrica" - Partes I e II - Prof. Dr. Dorel Soares Ramos e Prof. Dr. Donato da Silva Filho. Escola Politécnica da Universidade de São Paulo, 2011.

[37] MME - Ministério de Minas e Energia. Cartilha MME. Modelo Institucional do Setor Elétrico. Brasília, 2003.

[38] Marinho, R.R. - Estudo de alternativas de comercialização para alavancar a viabilidade econômica de Usinas Eólicas no Parque Gerador Brasileiro. Projeto de Formatura da Escola Politécnica da USP, São Paulo, 2011.

[39] Cesp - Companhia energética de São Paulo. Metodologia e Ferramental de Apoio à Decisão Empresarial para implantação de Empreendimentos de Geração Sazonal de Energia, contemplando mitigação de riscos de mercado e análise de Portfólio. Relatório 1. Novembro 2011.

[40] Kawana, S.A. - Impacto Decorrente dos Empreendimentos Eólicos instalados na região nordeste nos custos de transporte de energia elétrica no sistema interligado. Dissertação (Mestrado em Energia Elétrica) - Escola Politécnica da universidade de São Paulo. São Paulo, 2012.

[41] EPE - Empresa de Pesquisa Energética. Balanço Energético Nacional 2011 Ano Base 2010. Brasília, 2012. Disponível em https://ben.epe.gov.br/downloads/Resultados_Pre_BEN_2012.pdf, acesso em 29.10.2012. 
[42] MME- Ministério de Minas e Energia. Resenha Energética Brasileira. Exercício de 2010 (Preliminar). Maio de 2012. Disponível em http://www.biblioteca.presidencia.gov.br/publicacoes-oficiais1/catalogo/conselhos/conselho-nacional-de-politica-energetica/resenha-energeticabrasileira-exercicio-de-2011-resultados-preliminares/view, acesso em 29.10.2012.

[43] EPE- Empresa de Pesquisa Energética. Plano Decenal de Expansão de $\begin{array}{llll}\text { Energia } & \text { Elétrica } & 2021 . & \text { Disponível }\end{array}$ http://www.epe.gov.br/PDEE/Forms/EPEEstudo.aspx, acesso em 29.10.2012.

\subsection{Legislação}

BRASIL. Presidência da República. Casa Civil. Medida Provisória nº 579, de 11 de setembro de 2012. Dispõe sobre as concessões de geração, transmissão e distribuição de energia elétrica, sobre a redução dos encargos setoriais, sobre a modicidade tarifária, e dá outras providências.

BRASIL. Presidência da República. Casa Civil. Lei n 9.427, de 26 de dezembro de 1996. Institui a Agência Nacional de Energia Elétrica - ANEEL, disciplina o regime das concessões de serviços públicos de energia elétrica e dá outras providências.

BRASIL. Presidência da República. Casa Civil. Lei n 9.648, de 27 de maio de 1998. Altera dispositivos das Leis no 3.890-A, de 25 de abril de 1961, no 8.666, de 21 de junho de 1993, no 8.987, de 13 de fevereiro de 1995, no 9.074, de 7 de julho de 1995, no 9.427, de 26 de dezembro de 1996, e autoriza o Poder Executivo a promover a reestruturação da Centrais Elétricas Brasileiras - ELETROBRÁS e de suas subsidiárias e dá outras providências.

BRASIL. Presidência da República. Casa Civil. Lei $n^{0}$ 10.848, de 15 de março de 2004. Dispõe sobre a comercialização de energia elétrica, altera as Leis nos 5.655 , de 20 de maio de 1971, 8.631, de 4 de março de 1993, 9.074, de 7 de julho de 1995, 9.427, de 26 de dezembro de 1996, 9.478, de 6 de agosto de 1997, 9.648, de 27 de maio de 1998, 9.991, de 24 de julho de 2000, 10.438, de 26 de abril de 2002, e dá outras providências. 
BRASIL. Presidência da República. Casa Civil. Lei no 10.847, de 15 de março de 2004. Autoriza a criação da Empresa de Pesquisa Energética - EPE e dá outras providências.

BRASIL. Presidência da República. Casa Civil. Lei $\mathbf{n}^{\circ}$ 10.438, de 26 de abril de 2002. Dispõe sobre a expansão da oferta de energia elétrica emergencial, recomposição tarifária extraordinária, cria o Programa de Incentivo às Fontes Alternativas de Energia Elétrica (Proinfa), a Conta de Desenvolvimento Energético (CDE), dispõe sobre a universalização do serviço público de energia elétrica, dá nova redação às Leis no 9.427, de 26 de dezembro de 1996, no 9.648, de 27 de maio de 1998, no 3.890-A, de 25 de abril de 1961, no 5.655, de 20 de maio de 1971, no 5.899, de 5 de julho de 1973, no 9.991, de 24 de julho de 2000, e dá outras providências.

BRASIL. Presidência da República. Casa Civil. Lei n 10.762, de 11 de novembro de 2003. Dispõe sobre a criação do Programa Emergencial e Excepcional de Apoio às Concessionárias de Serviços Públicos de Distribuição de Energia Elétrica, altera as Leis nos 8.631, de 4 de março de 1993, 9.427, de 26 de dezembro de 1996, 10.438 , de 26 de abril de 2002, e dá outras providências.

BRASIL. Presidência da República. Casa Civil. Lei nº 9.074, de 7 de julho de 1995. Estabelece normas para outorga e prorrogações das concessões e permissões de serviços públicos e dá outras providências.

BRASIL. Presidência da República. Casa Civil. Lei no 10.438, de 26 de abril de 2002. Dispõe sobre a expansão da oferta de energia elétrica emergencial, recomposição tarifária extraordinária, cria o Programa de Incentivo às Fontes Alternativas de Energia Elétrica (Proinfa), a Conta de Desenvolvimento Energético (CDE), dispõe sobre a universalização do serviço público de energia elétrica, dá nova redação às Leis no 9.427, de 26 de dezembro de 1996, no 9.648, de 27 de maio de 1998, no 3.890-A, de 25 de abril de 1961, no 5.655, de 20 de maio de 1971, no 5.899 , de 5 de julho de 1973, no 9.991, de 24 de julho de 2000, e dá outras providências.

BRASIL. Presidência da República. Casa Civil. Lei $\mathbf{n}^{\circ} \mathbf{9 . 4 7 8}$, de 6 de agosto de 1997. Dispõe sobre a política energética nacional, as atividades relativas ao 
monopólio do petróleo, institui o Conselho Nacional de Política Energética e a Agência Nacional do Petróleo e dá outras providências.

BRASIL. Presidência da República. Casa Civil. Decreto $n^{\circ}$ 5.163, de 30 de julho de 2004. Regulamenta a comercialização de energia elétrica, o processo de outorga de concessões e de autorizações de geração de energia elétrica, e dá outras providências.

BRASIL. Presidência da República. Casa Civil. Decreto nº 5.177 de 12 de agosto de 2004. Regulamenta os arts. 40 e 50 da Lei $n^{\circ}$ 10.848, de 15 de março de 2004, e dispõe sobre a organização, as atribuições e o funcionamento da Câmara de Comercialização de Energia Elétrica - CCEE.

BRASIL. Presidência da República. Casa Civil. Decreto $\mathbf{n}^{\circ} \mathbf{5 . 0 2 5}$, de 30 de março de 2004. Regulamenta o inciso I e os $\S \S 10,20,30,40$ e 50 do art. 3o da Lei no 10.438, de 26 de abril de 2002, no que dispõem sobre o Programa de Incentivo às Fontes Alternativas de Energia Elétrica - PROINFA, primeira etapa, e dá outras providências.

BRASIL. Presidência da República. Casa Civil. Decreto $\mathbf{n}^{\circ}$ 2.655, de 2 de julho de 1998. Regulamenta o Mercado Atacadista de Energia Elétrica, define as regras de organização do Operador Nacional do Sistema Elétrico, de que trata a Lei $n^{0}$ 9.648, de 27 de maio de 1998, e dá outras providências.

BRASIL. Presidência da República. Casa Civil. Decreto $\mathbf{n}^{\mathbf{0}}$ 6.048, de 27 de fevereiro de 2007. Altera os arts. 11, 19, 27, 34 e 36 do Decreto no 5.163, de 30 de julho de 2004, que regulamenta a comercialização de energia elétrica, o processo de outorga de concessões e de autorizações de geração de energia elétrica.

BRASIL. Presidência da República. Casa Civil. Decreto $n^{\circ}$ 6.353, de 16 de janeiro de 2008. Regulamenta a contratação de energia de reserva de que trata o § 30 do art. 3o e o art. 3o-A da Lei no 10.848, de 15 de março de 2004, altera o art. 44 do Decreto no 5.163, de 30 de junho de 2004, e o art. 2o do Decreto no 5.177, de 12 de agosto de 2004, e dá outras providências. 
BRASIL. Presidência da República. Casa Civil. Decreto nº 5.175 de 9 de agoto de 2004. Constitui o Comitê de Monitoramento do Setor Elétrico - CMSE de que trata o art. 14 da Lei no 10.848, de 15 de março de 2004.

BRASIL. Presidência da República. Casa Civil. Decreto nº 5.184 de 16 de agosto de 2004. Cria a Empresa de Pesquisa Energética - EPE, aprova seu Estatuto Social e dá outras providências.

ANEEL - Agência Nacional de Energia Elétrica. Resolução n² 265, de 13 de agosto de 1998. Estabelece as condições para o exercício da atividade de comercialização de energia elétrica.

ANEEL - Agência Nacional de Energia Elétrica. Resolução Normativa $n^{\circ}$ 67, de 8 de junho de 2004. Estabelece critérios para a composição da Rede Básica do Sistema Interligado Nacional, e dá outras providências.

ANEEL - Agência Nacional de Energia Elétrica. Resolução Normativa $n^{\circ}$ 247, DE 21 de dezembro de 2006. Estabelece as condições para a comercialização de energia elétrica, oriunda de empreendimentos de geração que utilizem fontes primárias incentivadas, com unidade ou conjunto de unidades consumidoras cuja carga seja maior ou igual a 500 kW e dá outras providências.

ANEEL - Agência Nacional de Energia Elétrica. Resolução Normativa $n^{\circ}$ 376, DE 25 de agosto de 2009. Estabelece as condições para contratação de energia elétrica, no âmbito do Sistema Interligado Nacional - SIN, por Consumidor Livre, e dá outras providências.

ANEEL - Agência Nacional de Energia Elétrica. Resolução ANEEL n² 264, de 13 de agosto de 1998. Estabelece as condições para Contratação de Energia Elétrica por Consumidores Livres.

ANEEL - Agência Nacional de Energia Elétrica. Resolução Normativa n 77, DE 18 de agosto de 2004. Estabelece os procedimentos vinculados à redução das tarifas de uso dos sistemas elétricos de transmissão e de distribuição, para empreendimentos hidroelétricos e aqueles com base em fonte solar, eólica, biomassa ou cogeração qualificada, cuja potência injetada nos sistemas de transmissão e distribuição seja menor ou igual a 30.000 kW. 
ANEEL - Agência Nacional de Energia Elétrica. Resolução Normativa nº 109, de 26 de outubro de 2004. Institui a Convenção de Comercialização de Energia Elétrica.

ANEEL - Agência Nacional de Energia Elétrica. Resolução Normativa n 409, de 10 de agosto de 2010. Estabelece critérios e procedimentos para participação de empreendimento hidrelétrico não despachado centralizadamente no Mecanismo de Realocação de Energia - MRE.

ANEEL - Agência Nacional de Energia Elétrica. Resolução Homologatória $\mathbf{n}^{\circ}$ 406, de 12 de dezembro de 2006. Estabelece o valor da Tarifa de Energia de Otimização - TEO, com vigência a partir de 10 de janeiro de 2007, para valorar a energia transferida entre as usinas participantes do Mecanismo de Realocação de Energia MRE, no âmbito da Câmara de Comercialização de Energia Elétrica - CCEE.

ANEEL - Agência Nacional de Energia Elétrica. Resolução Normativa nº $^{\circ 37}$, de 11 de novembro de 2008. Estabelece as disposições relativas à contratação de energia de reserva e aprova o modelo do Contrato de Uso da Energia de Reserva CONUER. 


\section{APÊNDICE A - INSTITUIÇÕES DO SETOR ELÉTRICO}

Este apêndice tem o objetivo de complementar o capítulo 2 que trata sobre Comercialização de Energia Elétrica. Com isso são apresentadas a seguir, são apresentadas as instituições do setor elétrico que foram criadas e alteradas pelo Novo Modelo do Setor Elétrico Brasileiro.

A Lei $n^{\circ}$ 9.478/1997 dispõe sobre a política energética nacional e institui o Conselho Nacional de Política Energética (CNPE) e o Decreto $n^{\circ}$ 3.520/2000 dispõe sobre a sua estrutura e funcionamento.

O Conselho Nacional de Política Energética (CNPE) é um órgão de assessoramento do Presidente da República. Sua função é formular políticas nacionais e medidas específicas destinadas a: promover o aproveitamento nacional dos recursos energéticos do País; assegurar em função das características regionais, o suprimento de insumos energéticos às áreas mais remotas ou de difícil acesso no país, rever periodicamente as matrizes energéticas aplicadas às diversas regiões do País; rever periodicamente as matrizes energéticas aplicadas às diversas regiões no País; estabelecer diretrizes para programas específicos, como os de uso de gás natural, do álcool, do carvão e da energia termonuclear; estabelecer diretrizes para importação e exportação de petróleo e seus derivados, gás natural e condensado; propor critérios de garantia de suprimento de energia elétrica que assegurem o equilíbrio adequado entre confiabilidade de fornecimento e modicidade de tarifas e preços; além de propor critérios gerais de garantia de suprimento, a serem considerados no cálculo das energias asseguradas e em outros respaldos físicos para a contratação de energia elétrica, incluindo importação.

A Lei $n^{\circ} 3.782 / 1960$ cria o Ministério de Minas e Energia (MME), cujos assuntos eram de competência do Ministério da Agricultura. Posteriormente, a Lei $n^{\circ}$ 8.208/1990 extinguiu O MME e transferiu suas atribuições ao Ministério da Infraestrutura. O MME foi criado novamente pela Lei $n^{\circ} 8.422 / 1992$.

A Lei $n^{\circ} \mathbf{1 0 . 6 8 3 / 2 0 0 3}$ define as competências do MME e o Decreto $n^{\circ} \mathbf{5 . 2 6 7 / 2 0 0 4}$ aprova a Estrutura Regimental e o Quadro Demonstrativo dos Cargos em Comissão e das Funções 
O Ministério de Minas e Energia (MME) é o órgão do Governo Federal responsável pela condução das políticas energéticas do país. Suas principais obrigações incluem a formulação e implementação de políticas para o setor energético, de acordo com as diretrizes definidas pelo CNPE. O MME é responsável por estabelecer o planejamento do setor energético nacional, monitorar a segurança do suprimentos do Setor Elétrico Brasileiro e definir ações preventivas para restauração da segurança de suprimento no caso de desequilíbrios conjunturais entre oferta e demanda de energia.

A Lei $n^{\circ}$ 10.847/2004 autoriza a criação da Empresa de Pesquisa Energética (EPE), vinculada ao MME e o Decreto $n^{\circ}$ 5.184/2004 a cria e aprova o seu Estatuto Social.

A Empresa de Pesquisa Energética (EPE) tem por finalidade prestar serviços na área de estudos e pesquisas destinadas a subsidiar o planejamento do setor energético. Suas principais atribuições incluem a realização de estudos e projeções da matriz energética brasileira, execução de estudos que propiciem o planejamento integrado de recursos energéticos, desenvolvimento de estudos que visem 0 planejamento de expansão da geração e da transmissão de energia elétrica de curto, médio e longo prazo, realização de análises de viabilidade técnico-econômica e sócio-ambiental de usinas, bem como a obtenção da licença ambiental prévia para aproveitamentos hidrelétricos e de transmissão de energia elétrica.

A Lei $n^{0}$ 10.848/2004 autoriza a constituição do Comitê de Monitoramento do Setor elétrico (CMSE) e o Decreto $n^{\circ} 5.175 / 2004$ o constitui, sob a coordenação direta do MME.

O Comitê de Monitoramento do Setor Elétrico (CMSE) tem a função de acompanhar e avaliar permanentemente a continuidade e a segurança do suprimento eletroenergético em todo o território nacional. Suas principais atribuições incluem: acompanhar o desenvolvimento das atividades de geração, transmissão, distribuição, comercialização, importação e exportação de energia elétrica; avaliar as condições de abastecimento e de atendimento; identificar dificuldades e obstáculos que afetem a regularidade e a segurança de abastecimento e expansão do setor e elaborar propostas para ajustes e ações preventivas que possam restaurar a segurança no abastecimento e no atendimento elétrico. 
A Lei $n^{0}$ 9.427/1996 institui a Agência Nacional de Energia Elétrica (ANEEL) e o Decreto $n^{\circ}$ 2.335/1997 estabelece sua constituição.

A Agência Nacional de Energia Elétrica (ANEEL) possui as atribuições de regular e fiscalizar a produção, transmissão e comercialização de energia elétrica, zelando pela qualidade dos serviços prestados, pela universalização do atendimento e pelo estabelecimento das tarifas para os consumidores finais, sempre preservando a viabilidade econômica e financeira dos Agentes e da indústria. As alterações promovidas em 2004 pelo novo modelo do setor estabeleceram como responsabilidade da ANEEL, direta ou indiretamente, a promoção de licitações na modalidade de leilão, para a contratação de energia elétrica pelos Agentes de distribuição do Sistema Interligado Nacional (SIN).

A Lei $n^{\circ}$ 9.648/1998 cria o Operador Nacional do Sistema Elétrico (ONS), o Decreto $n^{\circ} \mathbf{2 . 6 5 5 / 1 9 9 8}$ o regulamenta, com posteriores alterações no Decreto $n^{\circ} 5.081 / 2004$.

O Operador Nacional do Sistema Elétrico (ONS) possui a função de operar, supervisionar e controlar a geração de energia elétrica no SIN, e administrar a rede básica de transmissão de energia elétrica no Brasil, com o objetivo principal de atender os requisitos de carga, otimizar custos e garantir confiabilidade do sistema, definindo ainda as condições de acesso à malha de transmissão em alta-tensão do país. As alterações implantadas a partir de 2004 trouxeram maior independência à governança do ONS, através da garantia de estabilidade do mandato de sua diretoria.

A Lei $n^{\circ}$ 10.848/2004 institui a Câmara de Comercialização de Energia Elétrica (CCEE) e o Decreto $n^{\circ} 5.177 / 2004$ a cria.

A Câmara de Comercialização de Energia Elétrica (CCEE) absorveu as funções e estruturas organizacionais e operacionais do MAE. Entre suas principais obrigações estão: a realização de leilões de compra e venda de energia no ACR por delegação da ANEEL; a apuração do Preço de Liquidação de Diferenças (PLD), utilizado para valorar as transações realizadas no mercado de curto prazo; a realização da contabilização dos montantes de energia elétrica comercializados e a liquidação financeira dos valores decorrentes das operações de compra e venda de energia elétrica realizadas no mercado de curto prazo. 
A figura a seguir representa as Instituções do Setor Elétrico Brasileiro:

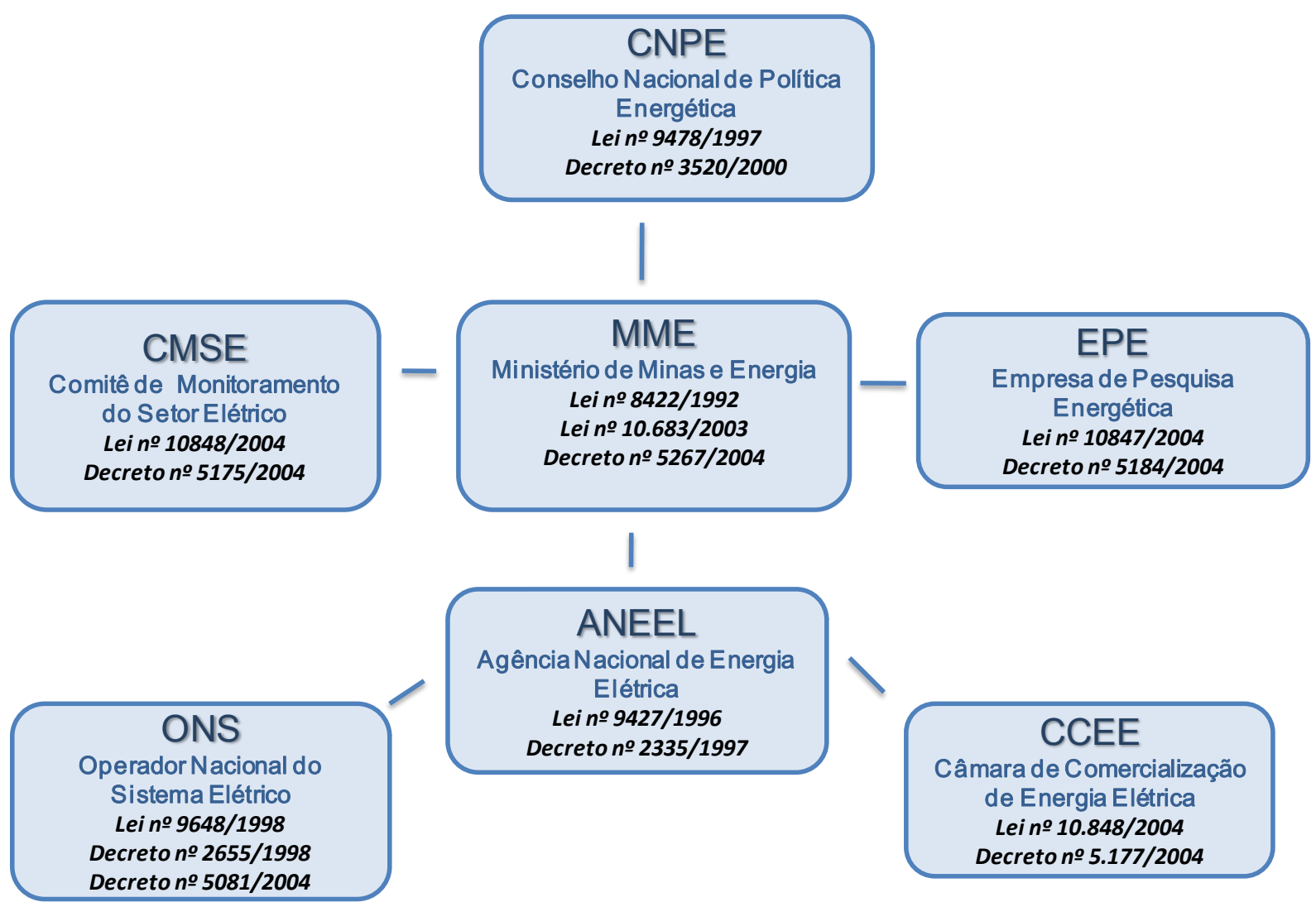

Figura 31: Instituições do Setor Elétrico Brasileiro.

Fonte: Elaboração própria. 


\section{APÊNDICE B - DADOS DE GERAÇÃO DE ENERGIA EÓLICA - ONS}

Este apêndice tem o objetivo de complementar o capítulo 6.1.1 (Complementação de Energia Eólica às PCH's), apresentando as informações utilizadas para a geração dos gráficos 10, 11 e 12, que foram gerados a partir das informações de geração fornecidas pelo Operador Nacional do Sistema Elétrico em (www.ons.gov.br).

\begin{tabular}{|c|r|r|r|r|r|r|}
\hline \multicolumn{7}{|c|}{ Geração de Energia Eólica - SIN } \\
\hline & $\mathbf{2 0 1 1}$ & $\mathbf{2 0 1 0}$ & $\mathbf{2 0 0 9}$ & $\mathbf{2 0 0 8}$ & $\mathbf{2 0 0 7}$ & $\mathbf{2 0 0 6}$ \\
\hline Jan & 95,29 & 110,72 & 58,66 & 73,02 & 59,83 & \\
\hline Fev & 94,57 & 163,4 & 49,33 & 61,01 & 54,02 & \\
\hline Mar & 101,62 & 146,06 & 54,29 & 39,3 & 38,61 & \\
\hline Abr & 59,29 & 105,73 & 33,62 & 31,37 & 51,96 & 0,48 \\
\hline Mai & & 140,73 & 40,29 & 55,31 & 53,4 & 1,98 \\
\hline Jun & & 151,03 & 60,91 & 58,07 & 55,32 & 6,71 \\
\hline Jul & & 145,81 & 53,9 & 50,17 & 60,55 & 24,37 \\
\hline Ago & & 207,13 & 78,17 & 70,03 & 87,72 & 37,42 \\
\hline Set & & 268,29 & 120,96 & 86,46 & 75,43 & 50,85 \\
\hline Out & & 191,09 & 138,63 & 78,64 & 90,73 & 69,1 \\
\hline Nov & & 219,35 & 150,94 & 88,96 & 68 & 66,14 \\
\hline Dez & & 168,19 & 134,12 & 68,67 & 69,05 & 54,07 \\
\hline
\end{tabular}

Tabela 13: Tabela de Geração de Energia Eólica no SIN (MW médios). Fonte: ONS.

Os dados de geração de energia eólica para o período de janeiro a março de 2006, para ageração do gráfico acima, não foi disponibilizado pelo Operador Nacional do Sistema elétrico (ONS). 


\begin{tabular}{|l|r|r|r|r|}
\hline \multicolumn{5}{|c|}{ Geração de Energia Eólica Norte e } \\
Nordeste \\
\hline \multicolumn{5}{|c|}{ Www.ons.gov.br } \\
\hline & $\mathbf{2 0 1 1}$ & $\mathbf{2 0 1 0}$ & $\mathbf{2 0 0 9}$ & $\mathbf{2 0 0 8}$ \\
\hline Jan & 68,29 & 76,13 & 14,66 & 18,01 \\
\hline Fev & 70,35 & 136,18 & 12,27 & 14,9 \\
\hline Mar & 42,18 & 108,65 & 8 & 5,2 \\
\hline Abr & 34,82 & 83,97 & 3,77 & 5,45 \\
\hline Mai & 53,37 & 101,46 & 4,51 & 6,95 \\
\hline Jun & 70,96 & 104,12 & 9,54 & 12,87 \\
\hline Jul & 108,81 & 93,61 & 8,85 & 18,27 \\
\hline Ago & 198,14 & 163,24 & 36,96 & 17,79 \\
\hline Set & 240,38 & 200,81 & 69,51 & 20,97 \\
\hline Out & & 154,82 & 86,42 & 26,67 \\
\hline Nov & & 177,93 & 100,69 & 21,05 \\
\hline Dez & & 45,5 & 85,8 & 16,7 \\
\hline
\end{tabular}

Tabela 14: Gráfico de Geração de Energia Eólica - Norte e Nordeste (MW médios). Fonte: ONS.

Dados de geração de energia eólica disponibilizados pelo Operador Nacional do Sistema elétrico (ONS) utilizados para a geração do gráfico acima, deste trabalho.

\begin{tabular}{|c|c|c|c|c|}
\hline \multicolumn{5}{|c|}{ Geração de Energia Eólica S_SE_Co } \\
\hline & $\mathbf{2 0 1 1}$ & $\mathbf{2 0 1 0}$ & $\mathbf{2 0 0 9}$ & $\mathbf{2 0 0 8}$ \\
\hline Jan & 27,00 & 34,59 & 44,00 & 55,01 \\
\hline Fev & 24,22 & 27,22 & 37,06 & 46,11 \\
\hline Mar & 59,44 & 37,41 & 46,29 & 34,10 \\
\hline Abr & 24,47 & 21,76 & 29,85 & 25,92 \\
\hline Mai & 35,47 & 39,27 & 35,78 & 48,36 \\
\hline Jun & 86,00 & 46,91 & 51,37 & 45,20 \\
\hline Jul & 92,98 & 52,20 & 45,05 & 31,90 \\
\hline Ago & 124,18 & 43,89 & 41,21 & 52,24 \\
\hline Set & 100,56 & 67,48 & 51,45 & 65,49 \\
\hline Out & & 36,27 & 52,21 & 51,97 \\
\hline Nov & & 41,42 & 50,25 & 67,91 \\
\hline Dez & & 122,69 & 48,32 & 51,97 \\
\hline
\end{tabular}

Tabela 15: Gráfico de Geração de Energia Eólica - S_SE_CO (MW médios). Fonte: ONS.

Dados de geração de energia eólica disponibilizados pelo Operador Nacional do Sistema elétrico (ONS) utilizados para a geração do gráfico acima, deste trabalho. 


\section{APÊNDICE C - SIMULAÇÕES - COMPLEMENTARIEDADE DE GERAÇÃO ENTRE FONTES RENOVÁVEIS}

Este apêndice tem o objetivo de complementar o capítulo 6.2 Análise de Complementaridade de geração entre fontes renováveis de produção sazonal Geração de Energia Eólica e Termelétricas movidas a Biomassa com PCH's.

Para a realização das simulações apresentadas no referido capítulo, foram utilizadas informações já estudadas em trabalhos anteriores [11], [28] e [38].

No trabalho [28] foi desenvolvida uma planilha "software" para tratar de séries hidrológicas e correspondentes preços 'spot' obtidos a partir de simulação do Sistema Interligado Nacional - SIN com o modelo de planejamento NEWAVE, possibilitando a avaliação das estratégias de comercialização de energia elétrica por PCH's.

No trabalho [11] foi recuperado um estudo detalhado [28] sobre o nível ótimo de contratação das PCH's e desenvolvido um racional semelhante para analisar térmicas isoladamente, verificando nível de contrato que uma termelétrica com cogeração poderia ter e, finalmente juntada as duas usinas para verificar a sinergia entre os dois tipos de tecnologia do ponto de vista econômico e comercial.

Dito isto, conforme já dito, para essa análise foram utilizados dados já trabalhados anteriormente [11], acrescidos de dados de geração de energia eólica (ONS) do perfil nordeste, e simulados por meio de um programa elaborado em excel com macros [38]. 